A \リロ2 I52942 NATL INST OF STANDARDS \& TECH R.I.C.

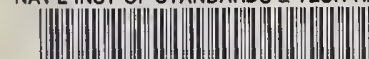

A11102152942

NBS bullding sclence series

miscom

ivere arde

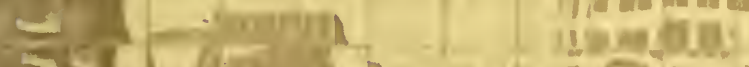

PिI

(9)

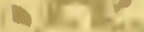

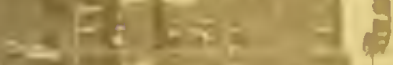

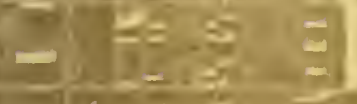

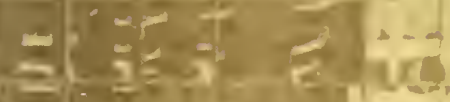

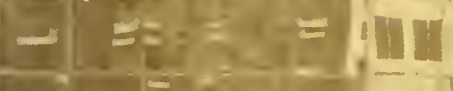

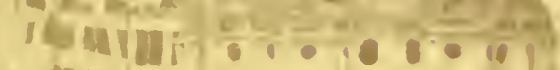

150

III

x. 2 ang.

11100

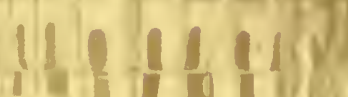

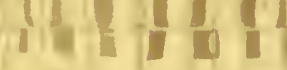

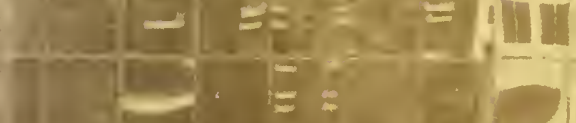

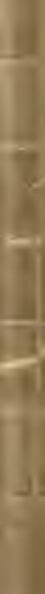

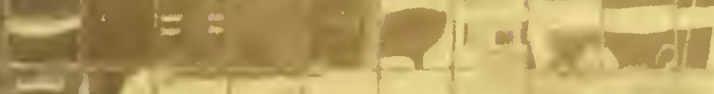

a.

प्रत्ये

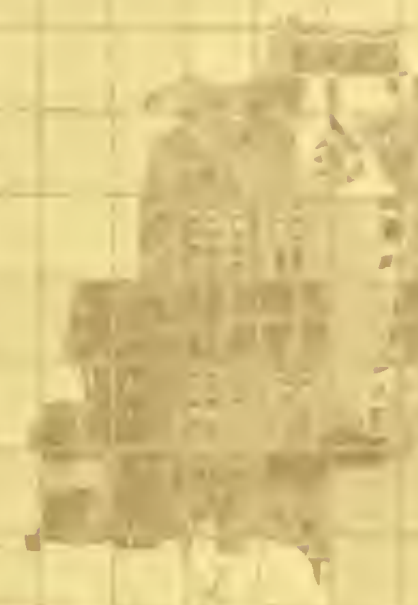

NBS BUILDING SCIENCE SERIES 161

\title{
Effectiveness of Solar Shading for an Office Building
}

$-T A$

435

.453

NO.161 PARTMENT OF COMMERCE • NATIONAL BUREAU OF STANDARDS

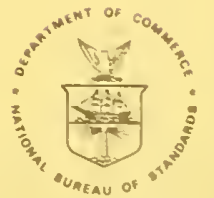
1984 


\section{NATIONAL BUREAU OF STANDARDS}

The National Bureau of Standards' was established by an act of Congress on March 3, 1901. The Bureau's overall goal is to strengthen and advance the Nation's science and technology and facilitate their effective application for public benefit. To this end, the Bureau conducts research and provides: (1) a basis for the Nation's physical measurement system, (2) scientitic and technological services for industry and government, (3) a technical basis for equity in trade, and (4) technical services to promote public safety. The Bureau's technical work is performed by the National Measurement Laboratory, the National Engineering Laboratory, and the Institute for Computer Sciences and Technology.

THE NATIONAL MEASUREMENT LABORATORY provides the national system of physical and chemical and materials measurement; coordinates the system with measurement systems of other nations and furnishes essential services leading to accurate and uniform physical and chemical measurement throughout the Nation's scientific community, industry, and commerce; conducts materials research leading to improved methods of measurement, standards, and data on the properties of materials needed by industry, commerce, educational institutions, and Government; provides advisory and research services to other Government agencies; develops, produces, and distributes Standard Reference Materials; and provides calibration services. The Laboratory consists of the following centers:

\section{Absolute Physical Quantities ${ }^{2}$ - Radiation Research - Chemical Physics - Analytical Chemistry - Materials Science}

THE NATIONAL ENGINEERING LABORATORY provides technology and technical services to the public and private sectors to address national needs and to solve national problems; conducts research in engineering and applied science in support of these efforts; builds and maintains competence in the necessary disciplines required to carry out this research and technical service; develops engineering data and measurement capabilities; provides engineering measurement traceability services; develops test methods and proposes engineering standards and code changes; develops and proposes new engineering practices; and develops and improves mechanisms to transfer results of its research to the ultimate user. The Laboratory consists of the following centers:

Applied Mathematics - Electronics and Electrical Engineering ${ }^{2}$ - Manufacturing Engineering - Building Technology - Fire Research - Chemical Engineering ${ }^{2}$

THE INSTITUTE FOR COMPUTER SCIENCES AND TECHNOLOGY conducts research and provides scientific and technical services to aid Federal agencies in the selection, acquisition, application, and use of computer technology to improve effectiveness and economy in Government operations in accordance with Public Law 89-306 (40 U.S.C. 759), relevant Executive Orders, and other directives; carries out this mission by managing the Federal Information Processing Standards Program, developing Federal ADP standards guidelines, and managing Federal participation in ADP voluntary standardization activities; provides scientific and technological advisory services and assistance to Federal agericies; and provides the technical foundation for computer-related policies of the Federal Government. The Institute consists of the following centers:

Programming Science and Technology-Computer Systems Engineering.

'Headquarters and Laboratories at Gaithersburg, MD, unless otherwise noted;

mailing address Washington, DC 20234.

${ }^{2}$ Some divisions within the center are located at Boulder, CO 80303. 


\title{
NBS BUILDING SCIENCE SERIES 161
}

\section{Effectiveness of Solar Shading for an Office Building}

\author{
S. Treado \\ J. Barnett \\ W. Remmert
}

Center for Building Technology

National Engineering Laboratory

National Bureau of Standards

Washington, DC 20234

Sponsored by:

Design and Construction Division

General Services Administration

Washington, DC 20407

Naval Facilities Engineering Command

U.S. Navy

Washington, DC 20350

Directorate of Civil Engineering

U.S. Air Force

Washington, DC 20330

Office of Chief of Engineers

U.S. Army

Washington, DC 20310

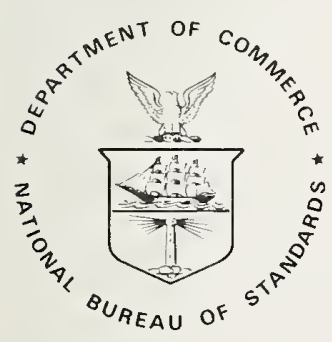

U.S. DEPARTMENT OF COMMERCE, Malcolm Baldrige, Secretary

NATIONAL BUREAU OF STANDARDS, Ernest Ambler, Director

Issued May 1984 
Library of Congress Catalog Card Number: 84-601038

National Bureau of Standards Building Science Series 161

Natl. Bur. Stand. (U.S.), Bldg. Sci. Ser. 161, 111 pages (May 1984) CODEN: BSSNBV 
The impact of solar shading of windows on building energy consumption, energy costs and occupant comfort is examined for a typical office building. Measurements of the solar and thermal performance characteristics of three solar screens are reported. Using the DOE-2 computer program, annual building energy simulations were performed for seven climatic locations in the United States. Thirteen combinations of window thermal transmittance and shading coefficient are examined for each location. The analysis includes separate evaluations for buildings with all-year cooling and summer-only cooling. The percentage of occupied hours when overheating occurs in perimeter office areas is presented. A life-cycle cost analysis is used to determine payback periods and savings-toinvestment ratios for three combinations of shading device first cost and expected life. The evaluation assumes that any shading devices are fixed, and that daylighting is not used to offset interior lighting requirements.

The results indicate that solar shading can reduce building energy consumption and improve comfort conditions in buildings with significant cooling loads. The optimum shading device characteristics vary with climatic location. Solar shading is more beneficial to buildings which are cooled all year, than buildings with summer-only cooling.

Keywords: Building energy analysis; cooling loads; heating loads; solar screens; solar shading; window management; windows. 


\section{A. AUTHORITY}

This study has been executed pursuant to a GSA/NBS agreement, through the National Capital Region Design and Construction Division of the General Services Administration.

\section{B. PURPOSE}

The objective of this study is to evaluate the effects of solar shading on heating and cooling loads and energy requirements of building HVAC system, and to determine the cost-effectiveness of solar shading for an office building for seven climatic regions of the United States. Guidelines are developed and presented to enable effective utilization of solar shading for office building applications.

\section{DISCLAIMER OF APPLICATION}

The results and analysis are intended to be used only for the purpose described herein, and may not be applicable to other cases. Neither GSA nor NBS are responsible for any other use or application of the data, results or conclusions contained in this report.

The user is cautioned to evaluate the local weather conditions, building design and type of construction, location, height usage, and other relevant factors prior to any application of the data, results or conclusions contained in this report. Each building must be considered on an individual basis. 


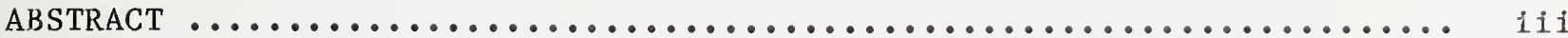

PREFACE ..................................................

LIST OF TABLES ............................................. . . . . . . .

LIST OF FIGURES ............................................. vii

ACKNOWLEDG MENTS ........................................... 1.

1. INTRODUCTION ............................................ 1

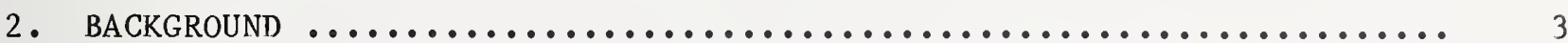

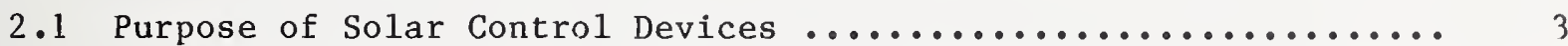

2.2 Solar and Thermal Performance ...........................

3. MEASUREMENTS OF SOLAR AND THERMAL PERFORMANCE OF SOLAR SCREENS ..... 7

3.1 Description of Screens ................................ 7

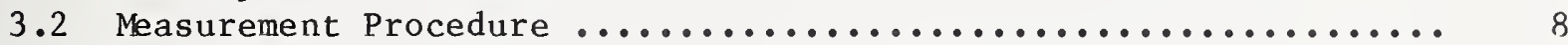

3.3 Measurement Results .....................................

4. BUILDING SIMLATION ........................................ $\ldots$

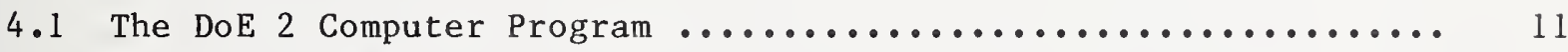

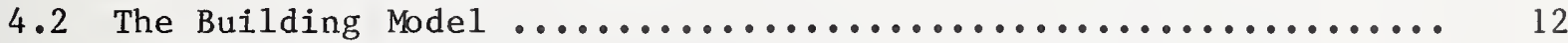

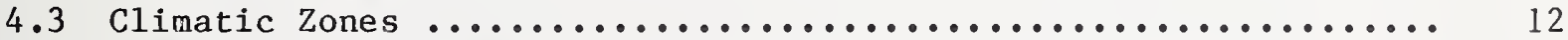

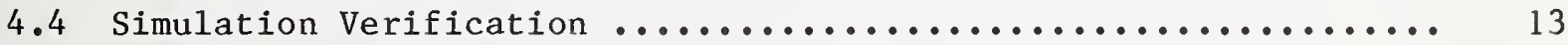

4.5 Computer Simulation Results for Seven Climatic Zones .......... 14

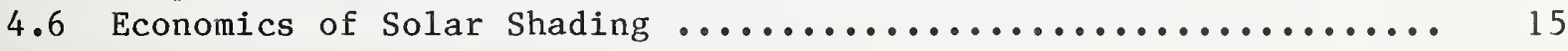

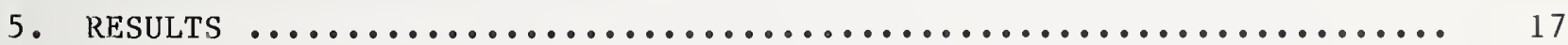

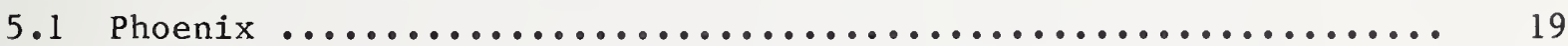

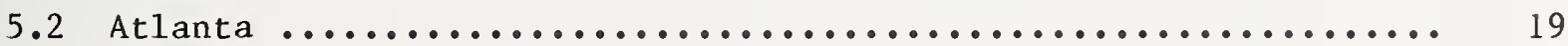

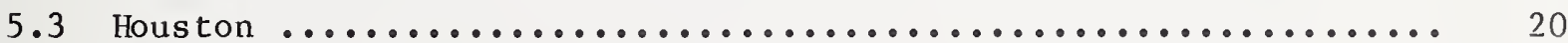

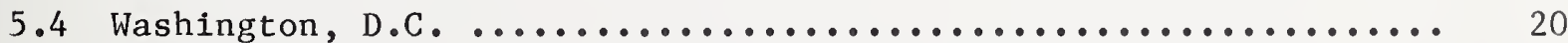

5.5 Chicago ............................................. 20

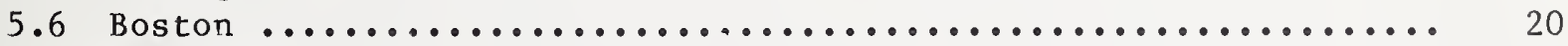

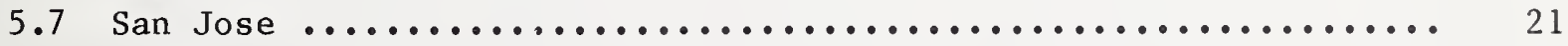

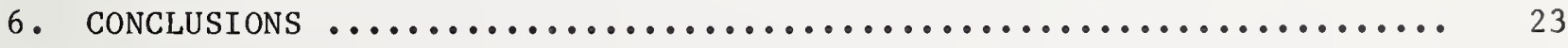

7. REFERENCES ............................................ . . . .

APPENDIX A - - DESCRIPTION OF BUILDING MODET ..................... 
Table 1 .

Description of Screens $\ldots \ldots \ldots \ldots \ldots \ldots \ldots \ldots \ldots \ldots$

Table 2 . Average Screen Properties

Table 3 . TRY Heating and Cooling Degree Days (Base $18.3 \mathrm{C}$ ) for Study

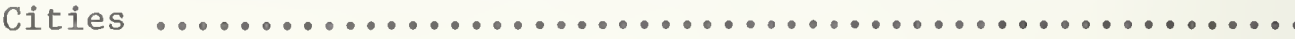

Table 4 .

Values of Shading Coefficients and U-factors Used for the

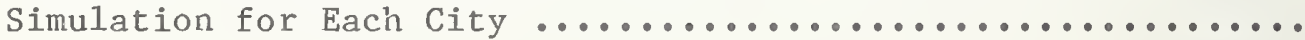

Table 5 .

Annual Energy Consumptions (MBTU) for the Subsystems of the Simulated Building (Washington, D.C. with Clear Glass) Summer-

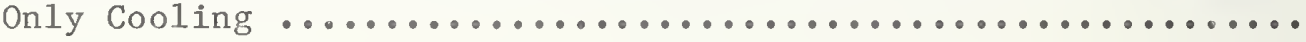

Table 6a. Cost-effectiveness for Phoenix $U=0.50$, Summer-only Cooling 46 Table 6b. Cost-effectiveness for Phoenix $U=0.84$, Summer-only Cooling . Cost-effectiveness for Phoenix $U=0.50$, All-year Cooling .... Cost-effectiveness for Phoenix $U=0.84$, All-year Cooling .... Cost-effectiveness for Atlanta $U=0.50$, Summer-only Cooling . Cost-effectiveness for Atlanta $U=0.84$, Summer-on1y Cooling . Cost-effectiveness for Atlanta $U=0.50$, All-year Cooling .... Cost-effectiveness for Atlanta $U=0.84$, All-year Cooling .... Cost-effectiveness for Houston $U=0.50$, Summer-only Cooling . Cost-effectiveness for Houston $U=0.84$, Summer-only Cooling . Cost-effectiveness for Houston $U=0.50$, All-year Cooling .... Cost-effectiveness for Houston $U=0.84$, All-year Cooling... Cost-effectiveness for Washington, D.C. U $=0.50$, Summer-only Cooling .................................... 73

Table 9b. Cost-effectiveness for Washington, D.C. U $=0.84$, Summer-only

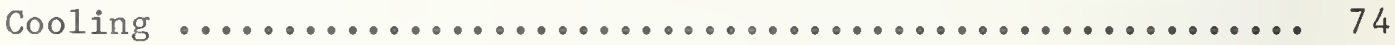

Table 9c. Cost-effectiveness for Washington, D.C.U $=0.50$, All-year

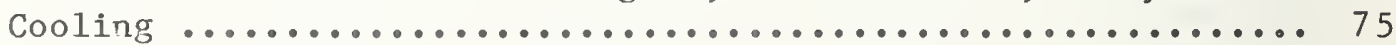

Table 9d. Cost-effectiveness for Washington, D.C. U = 0.84, All-year

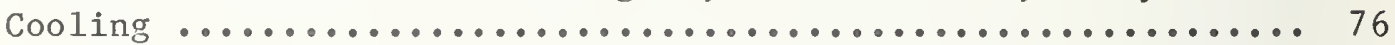

Table 10a. Cost-effectiveness for Chicago $U=0.50$, Summer-on1y Cooling . Table 10b.

Table 10c.

Table 10d.

Table 11a.

Table $1 \mathrm{lb}$.

Table 11c.

Table 11d. Cost-effectiveness for Chicago $U=0.84$, Summer-only Cooling . Cost-effectiveness for Chicago $U=0.50$, All-year Cooling .... Cost-effectiveness for Chicago $U=0.84$, All-year Cooling .... Cost-effectiveness for Boston $U=0.50$, Summer-only Cooling .. Cost-effectiveness for Boston $U=0.84$, Summer-only Cooling .. Cost-effectiveness for Boston $U=0.50$, All-year Cooling... . Cost-effectiveness for Boston $U=0.84$, All-year Cooling ..... Cost-effectiveness for San Jose $U=0.50$, Summer-only

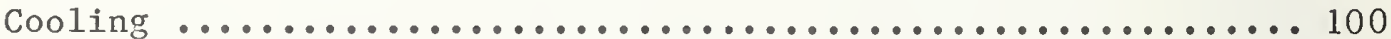

Table 12b. Cost-effectiveness for San Jose $U=0.84$, Summer-only

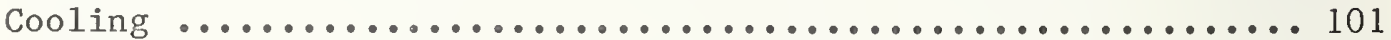

Table 12c. Cost-effectiveness for San Jose U = 0.50, All-year Cooling ... 102 Table 12d. Cost-effectiveness for San Jose U = 0.84, All-year Cooling ... 103 


\section{LIST OF FIGURES}

Page

Figure 1. Schematic diagram of window calorimeter ............ 30

Figure 2. Photograph of window calorimeter apparatus ........... 31

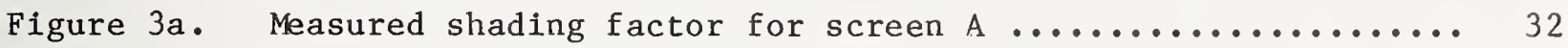

Figure $3 b . \quad$ Measured shading factor for screen $B \ldots \ldots \ldots \ldots \ldots \ldots$

Figure $3 c$. Measured shading factor for screen $c \ldots \ldots \ldots \ldots \ldots \ldots$

Figure 4a. Measured thermal transmittance for screen A .......... 35

Figure 4b. Measured thermal transmittance for screen B ........... 36

Figure 4c. Measured thermal transmittance for screen $c \ldots \ldots \ldots . . . . .37$

Figure $5 . \quad$ Photograph of study building $\ldots \ldots \ldots \ldots \ldots \ldots \ldots \ldots \ldots \ldots$

Figure 6 . Map showing locations of climatic regions ............ 39

Figure 7. Monthly energy consumptions for actual and simulated

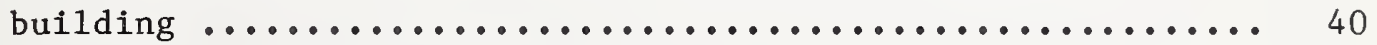

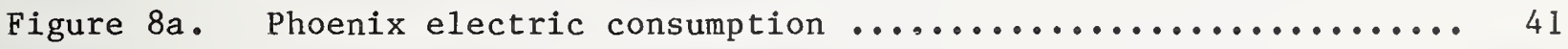

Figure $8 \mathrm{~b} . \quad$ Phoenix steam consumption ...................... 42

Figure $8 c . \quad$ Phoenix total building energy .................... 43

Figure $8 \mathrm{~d}$. Phoenix percent hours overheating, $U=0.50 \ldots \ldots \ldots . \ldots 4$

Figure 8 e. Phoenix percent hours overheating, $U=0.84 \ldots \ldots \ldots \ldots$

Figure $9 a . \quad$ Atlanta electric consumption $\ldots \ldots \ldots \ldots \ldots \ldots \ldots \ldots \ldots$

Figure $9 \mathrm{~b}$. Atlanta steam consumption $\ldots \ldots \ldots \ldots \ldots \ldots \ldots \ldots \ldots$

Figure $9 c . \quad$ Atlanta total building energy $\ldots \ldots \ldots \ldots \ldots \ldots \ldots \ldots \ldots$

Figure 9d. Atlanta percent hours overheating, $U=0.50 \ldots \ldots \ldots$

Figure 9e. Atlanta percent hours overheating, $U=0.84 \ldots \ldots \ldots \ldots$

Figure 10a. Houston electric consumption ...................... 59

Figure 10b. Houston steam consumption ....................... 60 


\section{LIST OF FIGURES (Continued)}

Figure $10 \mathrm{c}$. Houston total building energy $\ldots \ldots \ldots \ldots \ldots \ldots \ldots \ldots \ldots \ldots$

Figure 10d. Houston percent hours overheating, $U=0.50 \ldots \ldots \ldots \ldots . \ldots 6$

Figure 10e. Houston percent hours overheating, $U=0.84 \ldots \ldots \ldots \ldots \ldots .63$

Figure 1la. Washington, D.C. electric consumption ............... 68

Figure 11b. Washington, D.C. steam consumption ................ 69

Figure 1lc. Washington, D.C. total building energy ............... 70

Figure 11d. Washington, D.C. percent hours overheating, $U=0.50 \ldots \ldots 7$

Figure 1le. Washington, D.C. percent hours overheating, $U=0.84 \ldots \ldots .72$

Figure 12a. Chicago electric consumption $\ldots \ldots \ldots \ldots \ldots \ldots \ldots \ldots \ldots \ldots \ldots$

Figure 12b. Chicago steam consumption ...................... 78

Figure 12c. Chicago total building energy ...................... 79

Figure 12d. Chicago percent hours overheating, $U=0.50 \ldots \ldots \ldots \ldots$

Figure $12 \mathrm{e}$. Chicago percent hours overheating, $\mathrm{U}=0.84 \ldots \ldots \ldots \ldots \ldots . . .81$

Figure 13a. Boston electric consumption $\ldots \ldots \ldots \ldots \ldots \ldots \ldots \ldots \ldots$

Figure 13b. Boston steam consumption ...................... 87

Figure 13c. Boston total building energy $\ldots \ldots \ldots \ldots \ldots \ldots \ldots \ldots \ldots \ldots$

Figure 13d. Boston percent hours overheating, $U=0.50 \ldots \ldots \ldots \ldots . . . .89$

Figure 13e. Boston percent hours overheating, $U=0.84 \ldots \ldots \ldots \ldots \ldots \ldots$

Figure 14a. San Jose electric consumption ...................... 95

Figure 14b. San Jose steam consumption ........................ 96

Figure 14c. San Jose total building energy .................... 97

Figure 14d. San Jose percent hours overheating, $U=0.50 \ldots \ldots \ldots \ldots$

Figure 14e. San Jose percent hours overheating, $U=0.84 \ldots \ldots \ldots \ldots . . .99$ 


\section{ACKNOWLEDG MEN'TS}

W. S. Fleming and Associates were consulted to develop the initial building simulation file for the DOE-2 computer procedure.

This work was supported by the National Capital Region of the General Services Administration. Additional support was provided by the Naval Facilities Engineering Command, the Directorate of Civil Engineering (Air Force) and the Office of Chief of Engineers (U.S. Army). 



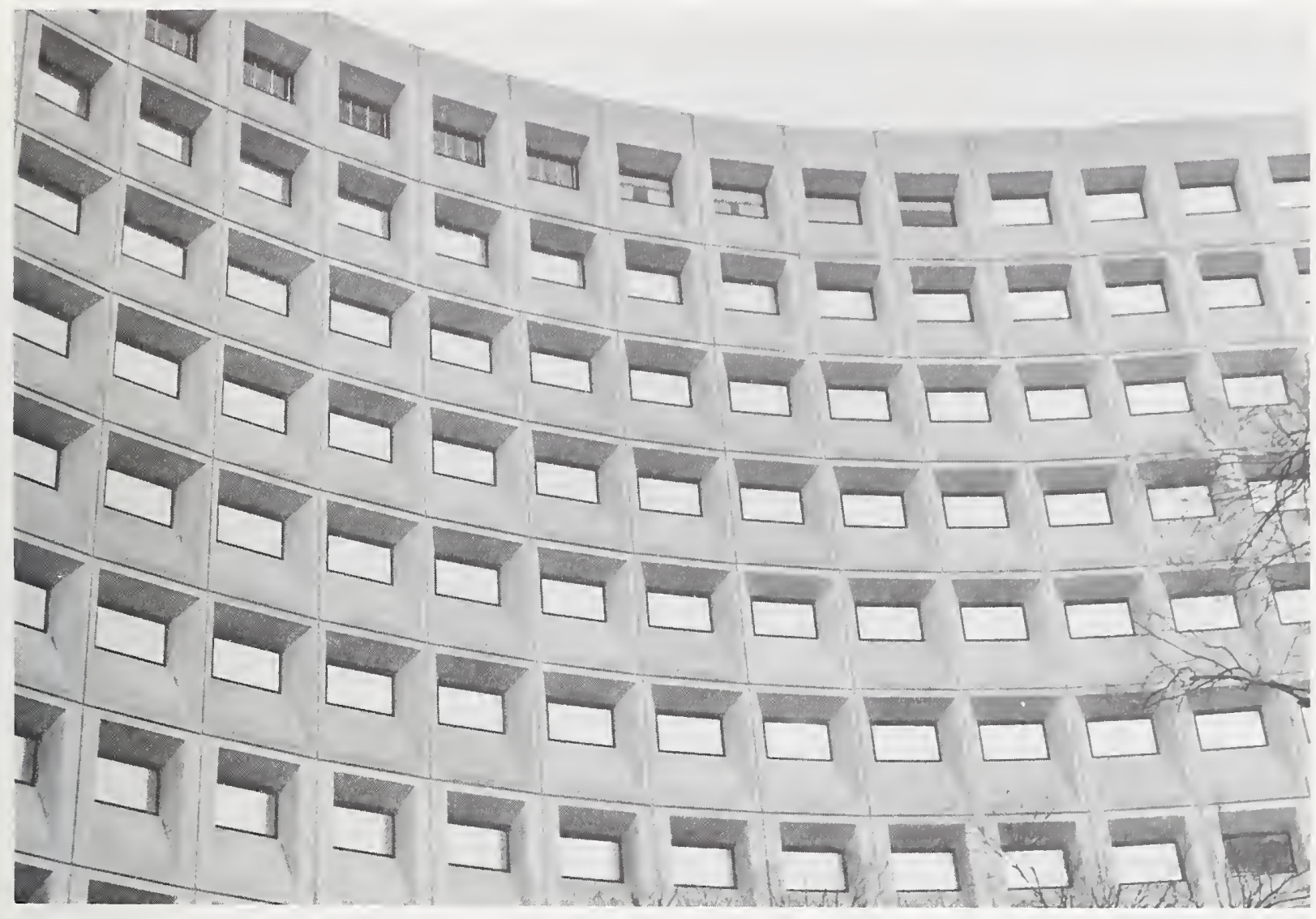

\section{INTRODUCTION}

Fenestration systems are integral and important components of building envelopes. Typical windows admit large fractions of incident solar radiation, and allow relatively high rates of heat exchange with the surroundings, compared to other portions of the building envelope. Window system properties, characteristics and designs have a significant impact on building energy requirements, building thermal performance, occupant comfort, and HVAC system sizing $[1,2,3]$.

For a new building design, proper selection and sizing of window systems can minimize building energy requirements while maintaining the benefits traditionally associated with windows. These benefits include daylight, view and occupant related psychological factors [4]. In existing buildings, window system retrofit procedures are sometimes needed to compensate for changes in 
HVAC equipment or operating schedules, or to improve building thermal performance and occupant comfort.

The use of daylight to reduce lighting energy needs (and cooling loads) can be particularly effective in minimizing annual total building energy requirements [5, 6, 7]. However, daylighting strategies usually require automatic lighting controls designed to maintain constant levels of interior illumination. In this evaluation, the daylighting effects of windows are not considered, since the incorporation of daylighting effects would greatly increase the complexity of the analysis, and since the report is concerned mainly with window system retrofit procedures for existing buildings which do not have automatic lighting control systems.

This report examines the impact of solar control strategies on annual building energy requirements, energy costs, and occupant comfort conditions for a typical office building with single glazing amounting to 54 percent of the total area of exterior building envelope. A wide range of window system options are examined on a parametric basis using thermal transmittance (U-factor) and shading coefficient (SC) to characterize each window system option. Comparisons are made between a base building with single-pane clear glass windows and the same building retrofitted with fixed solar shading systems, such as screens, films or shades. The analysis includes buildings with all-year cooling and summer-only cooling. In this manner, various solar shading options can be compared on the basis of their solar performance (SC) and thermal performance (U-factor) characteristics.

Results are presented for seven climatic regions of the United States. The evaluation includes measurements of the solar-thermal properties of three solar screens, and simulations of building thermal performance using the DOE-2.l computer program. The results of an economic analysis are presented in the form of payback period and savings-to-investment ratio, For three combinations of first cost and life. 


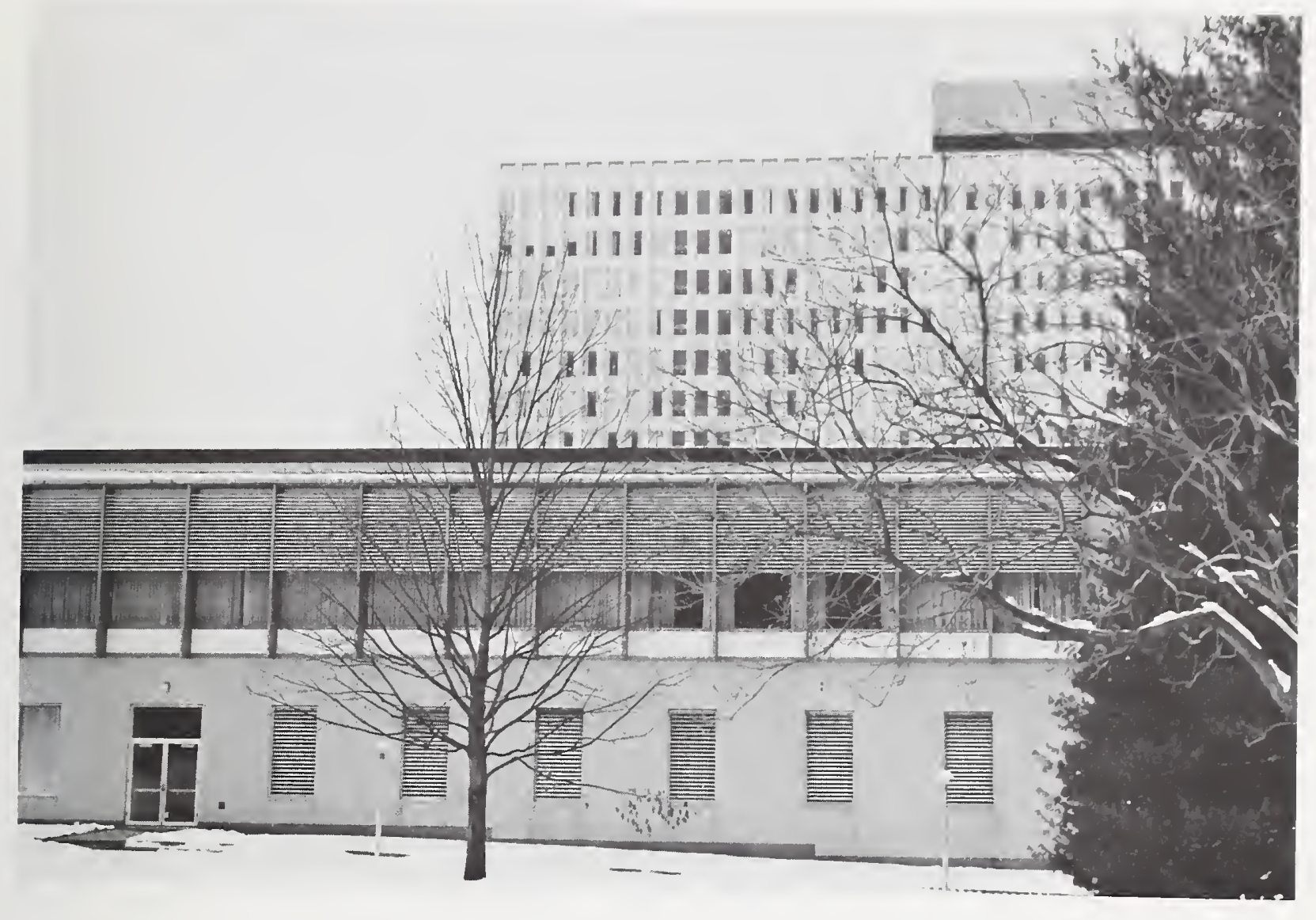

\section{BACKGROUND}

\subsection{PURPOSE OF SOLAR CONTROL DEVICES}

Solar shading devices and other window management systems are used to selectively alter the thermal and solar properties of building fenestration systems in order to reduce building energy requirements and to improve comfort conditions. The selection of window management strategies is strongly dependent upon building parameters, building location, and occupant requirements. When designing new buildings, fenestration systems can be specified by choosing from a wide range of alternatives, with the ultimate goal of minimizing energy requirements associated with the fenestration [8]. In existing buildings, fenestration retrofit alternatives are much more limited since the size and location of the fenstration are fixed. Thus, effective use of solar shading or other window management strategies requires different considerations for retrofit procedures than for new design applications. 
Windows can have a significant impact on building energy requirements for several reasons. First, conductive heat transfer (due to an inside-to-outside air temperature difference) is generally much greater through a window than through an equal area of wall [9]. The vast majority of the time, this conductive heat transfer results in increased heating and/or cooling loads, since the inside-to-outside air temperature difference causes a heat loss in winter and a heat gain in summer. Occasionally, conductive heat loss is a benefit, as on cool summer nights when the interior air temperature is warmer than the ambient air or cool days when internal heat sources can cause overheating.

The second major energy impact of windows is their transmission of solar energy. At first glance, it could be assumed that solar heat gain is a benefit in winter and a detriment in summer. While this assumption is basically correct, particularly for summer, excessive winter solar heat gain can cause overheating in areas near the windows, resulting in unacceptable comfort conditions, especially in buildings which are air-conditioned only in summer. The precise level of solar heat gain which would be considered excessive is a function of building and HVAC system design and operation and building internal heat gain, which varies from building to building.

The third major energy related impact of windows is the natural daylight admitted to interior spaces. Since lighting frequently accounts for 50 percent of the building's electrical energy requirements, the use of daylight to offset electric lighting can be very beneficial. However, since visible light is only a portion of the total solar spectrum, the admission of daylight also results in the admission of solar heat. Evaluation of the net effect of using solar radiation as a lighting source requires consideration of the trade-offs between solar heat gain, daylight levels, lighting requirements, and window thermal heat transfer. In addition, daylighting is used most effectively if the electric lighting is controlled in response to the available daylight.

Other window-associated considerations include glare and comfort conditions in perimeter building areas. Glare problems can occur near windows if the window appears very bright compared to the interior surfaces (walls, ceilings, partitions, etc.) [10]. This physiological effect is due to the response of the eye to the bright source (pupil contraction) causing other objects within the field of view to appear dim. Reflection of direct beam solar radiation from interior surfaces can also lead to glare problems. Building occupants are rarely comfortable if direct beam solar radiation impinges directly upon their bodies or work stations. In these cases, partial or total shading of the window is usually desired or implemented by the building occupants.

\subsection{SOLAR AND THERMAL PERFORMANCE}

Many different classes and types of solar shading devices are available. Some of the more common devices are:

- drapes, curtains

- shades

- blinds

- reflective films 
- screens (1ouvered or nonlouvered)

- shutters

- overhangs

These devices can be manually or automatically controlled, although most screens and films are fixed. Adjustable devices allow the benefit of tailoring the thermal and solar characteristics of the window to match the current weather conditions and building HVAC load conditions. That is, solar radiation can be admitted when beneficial (winter) and rejected in summer. In contrast, when fixed shading devices are used, their characteristics must be selected to provide the best annual performance, striking a balance between beneficial solar gains in winter and undesirable solar gains in summer. While adjustable solar shading devices have the potential for greater energy savings than fixed devices, studies have shown that in many cases manually adjustable devices are in fact left in fixed positions by the occupants for long periods of time [11]. Automatically adjusting devices can overcome this limitation, however they tend to be more complex and expensive, and long-term durability may be a significant consideration.

Solar shading devices reject incident solar radiation by reflection and absorption [12]. Reflected solar energy is instantly rejected while absorbed energy is partially convected and radiated to the exterior with the balance eventually transferred to the building interior. Louvered sun screens are configured to block incident radiation from high solar and sky elevations while allowing relatively unobstructed view of the ground. The transmittance of nonlouvered screens is greatest at normal incidence, where the transmittance is essentially controlled by the percentage of open mesh area. Transmittance decreases as incident angle deviates from normal in any direction. Thus, louvered screens can be more effective in rejecting direct beam solar radiation, particularly at high sun angles.

The solar control properties of solar shading devices can be characterized by two related parameters. The shading factor (F) is defined as the ratio of solar heat gain into the building to the solar energy incident upon the window. The shading coefficient (SC) is defined as the ratio of the shading factor of the solar shading device to the shading factor of a reference single-pane clear glass [13].

Utilization of solar shading devices also influences the thermal performance of a window, that is the heat transfer due to an inside-to-outside air temperature difference. For a single-pane window, most of the resistance to thermal heat transfer is provided by the air film on both window surfaces. The glass itself has a very low thermal resistance due to its small thickness [14]. Installation of a solar screen will increase the thermal resistance of the window system for two main reasons. First, a still-air space will be created between the outer window glass and the screen, in the manner of a double-pane window. The screen must fit tightly against the window frame on all sides for this effect to be significant. Second, the screen acts as a radiation shield, reducing infrared heat exchange between the window glass and the cold night sky or hot exterior surfaces [15]. Thus, the use of a solar screen should reduce the thermal transmittance (U-factor) of the window system. 
Exterior screens should be more effective in controlling solar heat gain than interior screens or shades, since a higher percentage of absorbed solar energy will be transferred to the outdoors. Interior shading devices tend to create a hot layer near the inside window surface and this heat can easily be transferred into the building space [16]. 


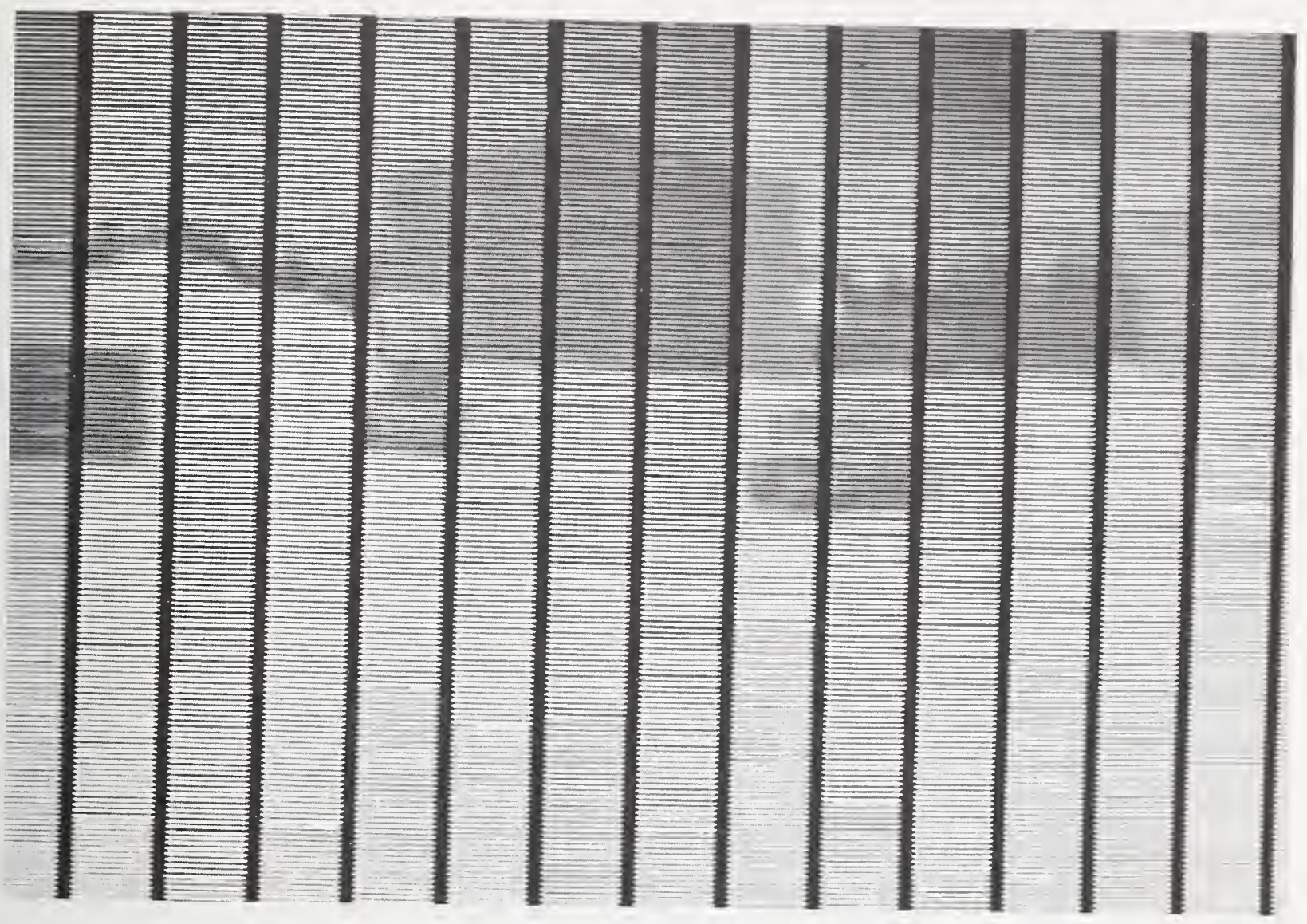

3. MEASUREMENTS OF SOLAR AND THERMAL PERFORMANCE OF SOLAR SCREENS

3.1 DESCRIPTION OF SCREENS

Three typical screens were examined, two louvered screens and one flat mesh screen. A description of the screens is given in table 1 . 
Table 1. Description of Screens

Screen A - Louvered, 23 louvers/in., width over spacing ratio 1.51/1, black colored, woven from bronze.

Screen B - Louvered, 17 louvers/in., width over spacing ratio $0.85 / 1$, unpainted aluminum.

Screen C- Nonlouvered, flat mesh, woven brown glass fiber, 22 percent open.

\subsection{MEASUREMENT PROCEDURE}

Measurements were made of the solar and thermal properties of the three solar screens. The thermal transmittance (U-factor) and shading factor (F) were determined from in situ measurements for a south-facing window, using a window calorimeter. A detailed description of the calorimeter has been previously published [17], but a brief description follows.

\section{Apparatus}

The window calorimeter was constructed of polystyrene with $12.7 \mathrm{~cm}$ ( 5 in.) thick walls. The overall dimensions of the box are $144.8 \mathrm{~cm}$ (57 in.) wide $\mathrm{x}$ $132.1 \mathrm{~cm}(52 \mathrm{in.)}$ deep $\times 198.1 \mathrm{~cm}$ (78 in.) high, with a window opening of $153.5 \times 96.4 \mathrm{~cm}(25 \times 38$ in.) (see figure 1$)$. The box is mounted flush with a south facing exterior wall (R40) with a cutout for the window so $1.5 \mathrm{~m}^{2}\left(16 \mathrm{ft}^{2}\right.$ ) of box wall and $0.6 \mathrm{~m}^{2}\left(6.6 \mathrm{ft}^{2}\right)$ of window area are exposed to exterior conditions. The box was mounted in the room so that none of the remaining five surfaces (floor, wall, ceiling, etc.) touched the wa11s, floor or ceiling of the room, thus maintaining an air space all around the box. The room air temperature was controlled to match the box air, so no significant heat transfer would occur through any portions of the box envelope except for the exterior wall. The window frame was constructed of polystyrene and was $20.3 \mathrm{~cm}$ ( 8 in.) deep total, with the glass inset $2.5 \mathrm{~cm}$ ( 1 in.) from the exterior. A photograph of the window calorimeter is shown in figure 2 .

The air temperature in the box was controlled using a water-to-air heat exchanger mounted inside the box, with a constantly operating circulation fan. The heat exchanger fan was a constant heat source in the box, releasing $94.1 \mathrm{w}$ $(321 \mathrm{Btu} / \mathrm{hr})$. The supply air was directed downward $0.5 \mathrm{~m}(1.5 \mathrm{ft})$ above the floor, with the return located near the box ceiling facing the window opening. Thus, supply air tended to sweep the walls of the box and good mixing was achieved. An individual HVAC system, consisting of a water chiller, in-1ine electric heater, pump, and storage tank in series with the box heat exchanger, enabled precise control of box air temperature. A temperature sensor in the heat exchanger return air stream was used to automatically control the operation of the chiller and heater to maintain box air temperature within a small band.

The amount of heat added to or extracted from the box (Q) was determined from the following equation: 


$$
Q=\stackrel{V}{V} C_{p} \Delta T
$$

where:

$$
\begin{aligned}
\dot{\mathrm{V}} & =\text { volumetric flow rate of water, } \\
\mathrm{d} & =\text { density of water, } \\
\mathrm{C}_{\mathrm{p}} & =\text { specific heat of water, and } \\
\Delta \mathrm{T} & =\text { temperature change of water flowing through box heat-exchanger. }
\end{aligned}
$$

The water flow rate was held constant, the specific heat of water was assumed to be a constant $4.2\left(10^{3}\right) \mathrm{J} / \mathrm{Kg} \cdot \mathrm{K}\left(1 \mathrm{Btu} / 1 \mathrm{~b} \cdot{ }^{\circ} \mathrm{F}\right)$ and the density of water was assumed to be a constant $1000 \mathrm{Kg} / \mathrm{m}^{3}\left(62.4 \mathrm{bb} / \mathrm{ft}^{3}\right)$.

The temperature rise of the circulating water was measured using a copperconstantan thermopile with 21 pairs of junctions which produced a millivolt signal proportional to the difference between the inlet and outlet water temperatures of the box heat-exchanger. The millivolt signal was read by an analog integrator which printed hourly integrated average values of the temperature difference for each hour. A rise in water temperature indicates heat extracted from the box (cooling), while a negative temperature difference indicates heating has occurred.

The window calorimeter test setup was instrumented with Type $\mathrm{T}$ thermocouples to measure various surface and air temperatures, solar pyranometers to measure incident and transmitted radiation, and an infrared prygeometer to measure incident long wave $(4-50 \mu \mathrm{m})(4000-50,000 \mathrm{Nm})$ radiation.

All of the sensors, except the box flowmeter and thermopile, were monitored using a microcomputer controlled data acquisition system. The sensor outputs were connected to a data logger which provided thermocouple temperature compensation and analog-to-digital conversion. The microcomputer continuously scanned all sensors, computing and printing average and instantaneous values every hour.

Subsequent processing provided separate files of reduced data, including temperature differences, derived quantities, and calculated components, and allowed inclusion of the box flowmeter and thermopile readings.

Thus, the hourly measurements of box heat loss/gain, temperature, and environmental conditions enabled determination of U-values, shading factors, shading coefficients, and window energy performance.

\subsection{MEASUREMENT RESULTS}

The measured shading factors for screens $A, B$, and $C$ are presented in figures $3 a, 3 b$, and $3 c$, respectively. These figures include measurements made over a 1 year period under a variety of seasonal and climatic conditions. Each screen was installed on the calorimeter, on a rotating basis and representative data is presented. 
The measured shading factors for screen A ranged primarily between 0.18 to 0.22 , screen $B 0.18$ to 0.32 , and screen $C 0.16$ to 0.32 . The variability in shading factor is due to the dynamic, nonuniform angular distribution of the incident solar radiation, which includes direct beam, diffuse sky, ground reflected and externally reflected energy.

The measured therma 1 transmittances of screens $A, B$, and $C$ are shown in figures $4 \mathrm{a}, 4 \mathrm{~b}$, and $4 \mathrm{c}$, respectively. The U-factors for all three screens were in the range between 2.3 to $5.4 \mathrm{w} / \mathrm{m}^{2} \mathrm{~K}\left(.40\right.$ to $\left..95 \mathrm{Btu} / \mathrm{h} \cdot \mathrm{ft}^{2}{ }^{\circ} \mathrm{F}\right)$. The variation in U-factor is due to its dependence on the magnitude of the air temperature difference across the window, air flow conditions at the window surfaces, and incoming infrared radiation from the surroundings [18].

Table 2 lists the average U-factors, shading coefficients for each of the three screens. These are the best values to use to obtain energy and costeffectiveness data from the computer simulation results.

Table 2. Average Screen Properties

\begin{tabular}{|lcccc|}
\hline & $\begin{array}{c}\mathrm{U}-\text { Factor } \\
\left(B \mathrm{Btu} / \mathrm{h}^{\circ} \mathrm{ft}^{2} \cdot \mathrm{F}\right)\end{array}$ & $\left(\mathrm{w} / \mathrm{m}^{2} \mathrm{~K}\right)$ & Shading Factor & Shading Coefficient* \\
\hline Screen A & .62 & 3.52 & .19 & .22 \\
Screen B & .65 & 3.64 & .24 & .28 \\
Screen C & .59 & 3.35 & .24 & .28 \\
\hline
\end{tabular}

* Assumes shading factor of 0.87 for clear glass as per ASHRAE Handbook of Fundamentals. 


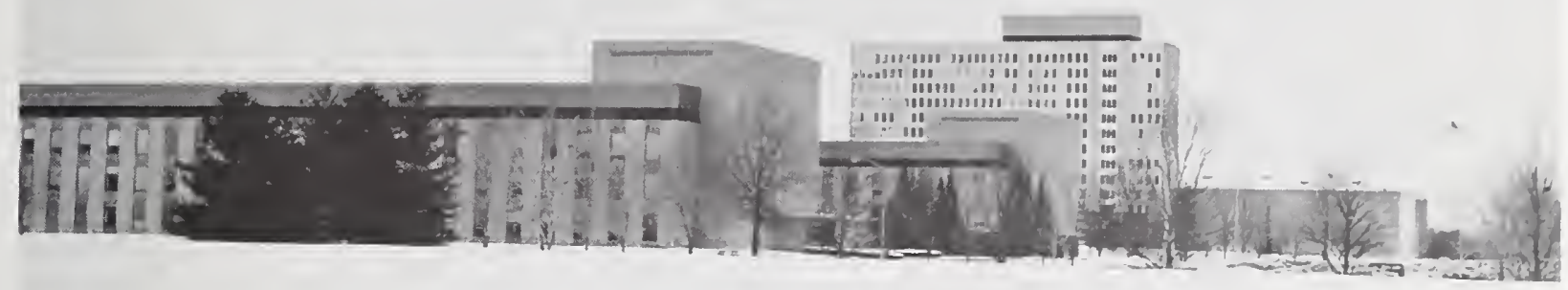

\section{BUILDING SIMULATION}

\subsection{THE DOE 2 COMPUTER PROGRAM}

The DOE computer program (version 2.1) was used in this study to predict the annual building energy requirements. The DOE program is a building energy analysis tool developed by the Department of Energy for improving the energy performance of buildings [19]. The program uses dynamic rather than steadystate calculation procedures and thus accounts for the thermal lag due to the building envelope construction. The algorithms used by the program are based on procedures developed by the American Society of Heating, Refrigerating, and Air-Conditioning Engineers. The program performs hour-by-hour simulations of the plant (e.g. boilers, chillers, cooling towers, etc.) and HVAC system (e.g., fans, coils, pumps, etc.) as they respond to variations in the weather induced envelope load and internal heat gains. 


\subsection{THE BUILDING MODEL}

The building considered in this study is a six-story federal office building located in Washington, D.C. The building is approximately $132 \mathrm{~m}$ (434 ft) long, $29 \mathrm{~m}$ (96 ft) wide, and $22 \mathrm{~m}$ (71 ft) high, having a gross above grade floor area of approximately $2322 \mathrm{~m}^{2}\left(249,984 \mathrm{ft}^{2}\right)$. The north and south facades of the building each have approximately $1608 \mathrm{~m}^{2}\left(17313 \mathrm{ft}^{2}\right.$ ) of glass area and the east and west facades each have approximately $342 \mathrm{~m}^{2}$ ( $3686 \mathrm{ft}^{2}$ ) of glass area. The windows are single-pane, clear glass with no operable sash, overhangs, or fins, and are mounted flush with exterior wall surface. Overall, approximately 54 percent of the gross exterior wall area consists of glass (see figure 5 for photograph). The long axis of the building runs in an east-west direction, with greatest exposures to the north and south. The ratio of glass area to wall area is the same on each facade.

After obtaining blueprints of the building, a walkthrough was conducted in order to gather additional information on space temperatures, occupancy, lighting, and equipment use. Interviews were also conducted with the personnel operating the building central equipment and daily operating records were reviewed. On the basis of this information the building model was developed, a description of which can be found in appendix $A$.

\subsection{CLIMATIC ZONES}

The "Test Reference Year" (TRY) hourly climate data tapes, prepared by the Nationa1 Oceanic and Atmospheric Administration (NOAA), were used in this study [20]. Each TRY data tape consists of one year's climate records chosen from a population of 27 years of records of the U.S. National Weather Service. The year chosen as the TRY year varies with location. The weather data are generally recorded at nearby airport weather stations. The weather variables used by the DOE program are:

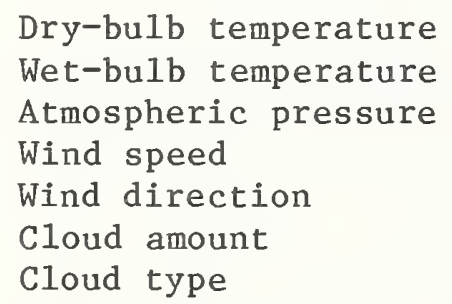

The GSA selected the following seven locations, giving a broad climatic variation, for this study:

Phoenix, Arizona

Houston, Texas

Atlanta, Georgia

Washington, D.C.

Chicago, Illinois

Boston, Massachusetts

San Jose, California 
Table 3 lists the cities and their TRY annual heating and cooling degree-days. Figure 6 shows a map of the United States with each of the seven locations used in the study.

Table 3. TRY Heating and Cooling Degree-Days (Base $18.3^{\circ} \mathrm{C}$ )* for Study Cities

\begin{tabular}{|lrrr}
\hline & CITY & HDD & CDD \\
& Phoenix & 842 & 1852 \\
& Houston & 888 & 1525 \\
& Atlanta & 1627 & 816 \\
& Washington, D.C. & 2312 & 828 \\
& Chicago & 3439 & 396 \\
& Boston & 3238 & 374 \\
* & 465 & 223 \\
Multiplication of the above HDD's and CDD's by 1.8 will give values in \\
degree-days base $65^{\circ} \mathrm{F}$.
\end{tabular}

\subsection{SIMULATION VERIFICATION}

A computer run was made using the Washington, D.C. TRY weather tape. The results of this run were then compared with the most recent annual energy consumption records (1980) for the building, to assure that the building model, together with the DOE computer program, adequately simulated the actual building. Figure 7 shows the monthly energy consumptions for both the simulated and actual building.

The predicted values for steam consumption track the metered values well (with the exception of the very high February metered value). It should be noted that the TRY weather tape was from a different year than the measured data. The predicted results for the prime heating months were expected to be somewhat greater than the metered values since the TRY weather tape heating degree-days (base $18.2^{\circ} \mathrm{C}$ ) are 7 percent greater than for the year 1980 (2312 vs. 2162).

The predicted values for electric consumption also track the metered values well except for the extremely low metered values for the months of March, April, and June. The previous years metered values show an average increase of slightly less than 10 percent each month in electric energy consumption from February through July. This correlates very well with the predicted results. It is unclear why the metered results are so low for March, April, and June in 1980. The metered results for the prime cooling months were expected to be higher than the predicted values since the cooling degree-days for 1980 are much higher than for the Washington, D.C. TRY weather tape (1115 vs. 828 ). 


\subsection{COMPUTER SIMULATION RESULTS FOR SEVEN CLIMATIC ZONES}

Nineteen computer simulations were run for each city. Baseline runs were made to establish the energy performance of the building with clear window glass for both the all-year cooling and summer-only cooling cases. In these runs it was assumed that clear glass covered the window areas on all four building facades. Additional runs were made, one for each different combination of shading coefficient and U-factor. In these runs it was assumed that the shading device had been placed on all glazing surfaces of the building. The U-values and shading coefficients used in this study are listed in table 4. A total of 139 computer simulations were run.

Table 4. Values of Shading Coefficients and U-Factors Used for the Simulation for Each City

\begin{tabular}{|cccc|} 
Run & SC & \multicolumn{2}{c}{$\mathrm{U}$} \\
\cline { 3 - 4 } & & & \\
1 & 1.0 & 1.17 & 6.64 \\
2 & 1.0 & 0.84 & 4.77 \\
3 & 0.8 & 0.84 & 4.77 \\
4 & 0.6 & 0.84 & 4.77 \\
5 & 0.4 & 0.84 & 4.77 \\
6 & 0.2 & 0.84 & 4.77 \\
7 & 0.1 & 0.84 & 4.77 \\
8 & 1.0 & 0.50 & 2.84 \\
9 & 0.8 & 0.50 & 2.84 \\
10 & 0.6 & 0.50 & 2.84 \\
11 & 0.4 & 0.50 & 2.84 \\
12 & 0.2 & 0.50 & 2.84 \\
13 & 0.1 & 0.50 & 2.84 \\
\hline
\end{tabular}

The computer simulation results were analyzed to determine electrical energy consumption, steam consumption, total building energy requirements and the percentage of occupied hours when overheating occurs in perimeter office areas. Overheating did not occur in the all-year cooled building. The first-year energy savings in dollars was calculated and used to determine payback periods and savings-to-investment ratios for each of three combinations of first cost and expected life for a shading device. The results are presented as functions of shading coefficient and U-factor, for each city. Thus, the user of this report can evaluate the energy, comfort and economic performance of generic solar shading devices, and determine the characteristics of the most appropriate device for a particular climatic region.

The building heating energy consumption is highly climate dependent, since it is primarily driven by ambient temperature and wind conditions. The building electric energy consumption, on the other hand, does not exhibit much climatic variation. This is because this building (like most office buildings) consumes 
a large quantity of electric energy for lighting and office equipment (see table 5) and the majority of the electric cooling energy is used to eliminate these internal heat gains. Thus there is little climate dependence in the electric cooling energy consumption and even less in the total electric energy consumption. The cooling energy consumption is about 5 percent of the total electric energy consumption for this building as simulated.

Table 5. Annual Energy Consumptions (MBTU) for the Subsystems of the Simulated Building (Washington, D.C. with Clear Glass), Summer-Only Cooling

\begin{tabular}{|c|c|c|c|c|}
\hline \multirow[b]{3}{*}{ In Situ } & \multicolumn{2}{|c|}{ Energy Type } & & \\
\hline & \multicolumn{2}{|c|}{ Steam } & \multicolumn{2}{|c|}{ Electricity } \\
\hline & MBtu & (GJ) & MBtu & (GJ) \\
\hline \multicolumn{5}{|l|}{ Category of Use } \\
\hline Space Heat & 10383 & $(10954)$ & 0 & \\
\hline Space Cool & 0 & & 1250 & $(1319)$ \\
\hline HVAC Auxiliary & 0 & & 3637 & $(3837)$ \\
\hline Domestic Hot Water & 1067 & (1125) & 0 & \\
\hline Auxiliary Solar & 0 & & 0 & \\
\hline Lights & 0 & & 11073 & $(11682)$ \\
\hline Vertical Trans. & 0 & & 1491 & $(1573)$ \\
\hline Miscellaneous Equipment & 0 & & 2350 & $(2479)$ \\
\hline TOTAL & 11450 & $(12080)$ & 19803 & $(20893)$ \\
\hline
\end{tabular}

\subsection{ECONOMICS OF SOLAR SHADING}

In order to determine if a particular solar shading device is cost-effective consideration must be given to energy costs, purchase and installation costs, and maintenance costs. In this report the first year dollar savings, the discounted payback period, and the savings-to-investment ratio are used to determined if a solar shading device is cost-effective. Installed costs of one, three, and six dollars per square foot are used, with expected life of 10 , 20 , and 30 years, respectively. A salvage value of zero was assumed, meaning any costs associated with removing worn shading devices was not considered. The solar shading device was assumed to require no extra maintenance cost.

The first year dollar savings were calculated from the following equation:

$$
\text { First year dollar savings }=(\mathrm{EC} * \mathrm{ECD})-(\mathrm{HEC} * \mathrm{HCI})
$$


where

$$
\begin{aligned}
\mathrm{EC} & =\text { electricity cost per } \mathrm{kWh}, \\
\mathrm{ECD} & =\text { electrical consumption decrease, } \\
\mathrm{HEC} & =\text { heating energy cost per } \mathrm{kWh}, \text { and } \\
\mathrm{HCI} & =\text { heating consumption increase. }
\end{aligned}
$$

In the above calculation, electrical demand rates were not considered and for gas and oil savings an annual system efficiency of 70 percent was assumed. The first year energy costs were typical costs for each region.

The discounted payback period was determined by calculating the cumulative savings in energy costs at yearly intervals until the savings met or exceeded the investment cost. That is, $M P W F E$ and $M P W F H$ were found for a year ( $Y$ ) such that the following equation was satisfied:

$$
E S * \operatorname{MPWF}_{\mathrm{E}}(\mathrm{Y})-\mathrm{H} \$ \text { * } \mathrm{MPFF}_{\mathrm{H}}(\mathrm{Y}) \geq \operatorname{COST}
$$

where

$\cos T$ = material, installation, and maintenance costs for useful life of solar shading device,

ULIFE = useful life of solar shading device,

$\mathrm{E} \$=\mathrm{EC} * \mathrm{ECD}=$ base year electricity dollar savings, $\operatorname{MPFF}_{E}(Y)=$ modified uniform present worth discount factor for electricity for given year $(Y)$ (the values for $M_{P W F}$ are taken from the tables in reference 21 and are based on a 7 percent real discount rate and include projected real escalation rates in energy cost) [21],

HS $=$ HEC * HCI = base year increase in cost for heating, and $\operatorname{MPWF}_{H}(\mathrm{Y})=$ modified uniform present worth discount factor for heating energy for a given year( $Y$ ) (from tables in reference 21).

The savings-to-investment ratios were calculated from the following equation:

$$
\text { Savings-to-investment ratio }=\frac{{ }^{\mathrm{S} * \mathrm{MPWF}} \mathrm{E}(\mathrm{ULIFE})-\mathrm{H}_{\mathrm{S}}^{*} \mathrm{MPWF} \mathrm{H}_{\mathrm{HLIFE})}}{\operatorname{COST}} .
$$




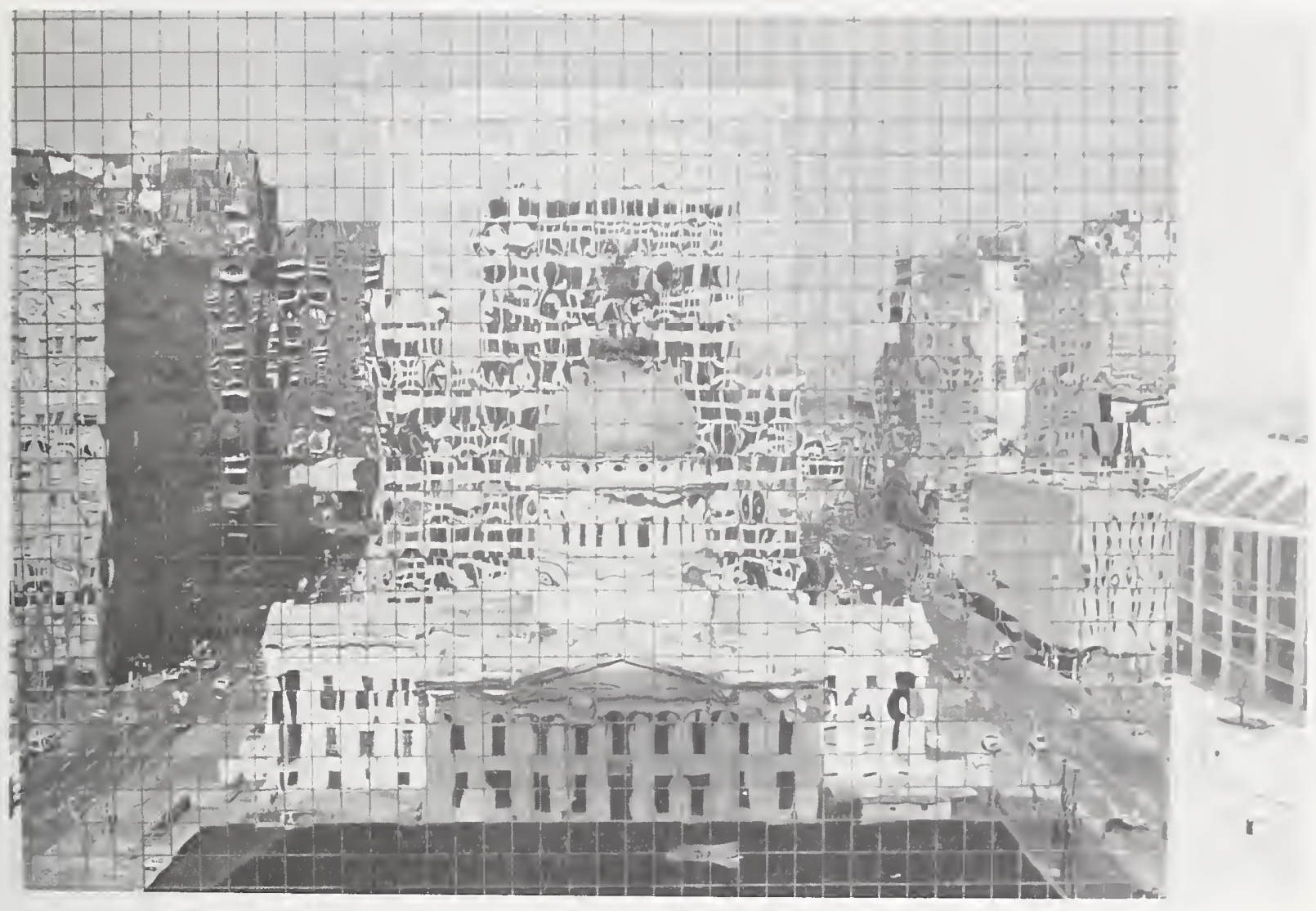

5. RESULTS

The results are presented separately for each city in a series of figures and tables. Data presented includes:

\section{For summer-only cooling}

1. Annual building electrical consumption as a function of shading coefficient, for $U$-factors of 0.50 and $0.84 \mathrm{Btu} / \mathrm{h} \cdot \mathrm{ft}^{2} \cdot \mathrm{F}$, and the base case $\mathrm{SC}=1.0$, $\mathrm{U}$-factor $=1.17 \mathrm{Btu} / \mathrm{h} \cdot \mathrm{ft}^{2} \cdot \mathrm{F}$.

2. Annual building steam consumption as a function of shading coefficient for $\mathrm{U}-\mathrm{f}$ actors of 0.50 and $0.84 \mathrm{Btu} / \mathrm{h} \cdot \mathrm{ft}^{2} \cdot \mathrm{F}$, and the base case.

3. Annual total building energy as a function of shading coefficient and U-factor. 
4. Annual percentage of occupied hours when overheating occurs in perimeter office areas, for north, south, east, and west facing offices, as a function of shading coefficient. Separate plots are presented for $U=0.50$ and $\mathrm{U}=0.84 \mathrm{Btu} / \mathrm{h} \cdot \mathrm{ft}^{2} \cdot \mathrm{F}$ (overheating is defined as space air temperature greater than $79^{\circ} \mathrm{F}$ ).

5. First year energy savings (dollars)

6. Payback periods (years) and savings-to-investment ratios for the three combinations of first cost and expected life. The combinations are $\$ 1$ per square foot-10 year life, $\$ 3$ per square foot-20 year life, and $\$ 6$ per square foot-30 year 1ife.

Items 5 and 6 are presented as separate sets of tables for each U-factor, as functions of shading coefficient.

For a11-year cooling

Items 5 and 6 from above are repeated for all-year cooling.

The tables and figures are designed to present the energy, comfort, and economic impacts of solar shading. While these results can only strictly be applied to buildings which are very similar to the study building, careful analysis of the results can prove useful in determining appropriate shading strategies and general design guidelines.

Several trends are apparent throughout all of the results.

- Electric energy consumption decreases with decreasing SC, with the lower U-factor usually causing a slight reduction or no net change,

- Steam consumption increases with decreasing SC, the lower U-factor decreases steam use significantly,

- The shape of the total energy curve as a function of shading coefficient exhibits the most variability among cities. For the warmweather cities, total energy use tends to decrease with decreasing SC, with the opposite true for cold-weather cities. Sometimes a minimum or relatively flat section is seen in the total energy curve.

- In buildings which are cooled only during summer, significant overheating can occur in perimeter office areas with unshaded windows. This is not only true for locations with hot climates, but also even in colder locations.

- South-facing offices exhibit the most overheating, with east and west about equa 1 .

- Shading saves more energy in all-year cooled buildings than in summercooled buildings, but shading of summer-cooled buildings reduces overheating due to solar gains in perimeter office areas. 
- The savings-to-investment ratios of $\$ 6 / f t^{2}$ shading systems are only cost-effective for the lower U-factor and only in areas with significant heating loads .

It should be noted that the overheating described above occurs on sunny days when the cooling system is not used, primarily spring and fall (for the summeronly cooling case, the cooling system in the study building was only operated between May 15 th and October 15 th, typical of federal buildings). In buildings which have year-round cooling system operation, this type of overheating would rarely occur, however electric consumption for cooling and heating energy consumption would be much greater.

\subsection{PHOENIX}

Electric consumption is minimum for SC of 0.1 (figure $8 \mathrm{a}$ ), and steam consumption minimum at SC of 1.0 (figure $8 \mathrm{~b}$ ). Minimum total energy consumption occurs at a SC of 0.2 , for the lower U-factor (figure $8 \mathrm{c}$ ). Figures $8 \mathrm{~d}$ and $8 \mathrm{e}$ show considerable overheating, even for the lowest shading coefficient. Since both total energy and overheating are minimum for the lower shading coefficients, a SC of 0.1 to 0.2 would be most effective. The higher U-factor causes a slightly lower percentage of overheating, and slightly higher total energy requirements.

Tables 6a through $6 \mathrm{~d}$ show the cost-effectiveness results for Phoenix, for $\mathrm{U}=0.50$ and $\mathrm{U}=0.84$, summer-only cooling and all-year cooling. Maximum dollar savings and savings-to-investment ratios, and minimum payback periods are seen to occur for the lower SC values. The low cost shading device $\left(\$ 1 / \mathrm{ft}^{2}, 10\right.$ year life) is the most favorable, while the high cost $\left(\$ 6 / \mathrm{ft}^{2}\right.$, 30 year life) is not. Savings are much greater for the all-year cooled buildings than the summer-only cooled building, because the former has a larger base case cooling load when shading is not used.

\subsection{ATLANTA}

Electric and steam consumption as functions of shading coefficient follow the usual pattern (figures $9 \mathrm{a}$ and $9 \mathrm{~b}$ ). Total building energy is minimum and fairly constant for SC between 0.4 and 1.0 . From an energy standpoint, a SC of 0.4 to 0.6 with the lower U-factor gives the best performance. However, the slightly higher total energy requirements for the lowest SC may be offset by the improved comfort conditions as evidenced by the plots of overheating hours, figures $9 \mathrm{~d}$ and $9 \mathrm{e}$.

The cost-effectiveness results are given in tables 7 a through $7 \mathrm{~d}$. Within each group, a SC of 0.1 to 0.2 has the shortest payback period, and highest savings to investment ratio. The $\$ 3 / \mathrm{ft}^{2}-20$ year life summer-only cooling case would not quite pay for itself during its expected lifetime, however, considering the uncertainty of predicting future energy prices and expected life for a shading device, may be cost-effective in an actual installation. The results are not favorable for the $\$ 6 / \mathrm{ft}-30$ year life cases. 


\subsection{HOUSTON}

Electric and steam consumption follow the usual pattern (figures 10a and 10b). From figure $10 \mathrm{c}$, total building energy is minimum for $\mathrm{SC}=0.1, \mathrm{U}=0.50$. Ten to 15 percent hours of overheating may occur even at SC $=0.1$, unless auxiliary shading (drapes, etc.) is used.

Tables $8 \mathrm{a}$ through $8 \mathrm{~d}$ show the cost-effectiveness results. The shading coefficient of 0.1 is most effective and the $\$ 3 / \mathrm{ft}^{2}-20$ year 1 ife cases are favorable, but the $\$ 1 / \mathrm{ft}^{2}-10$ year life rates the best.

\subsection{WAS HINGTON, D.C.}

Electric and steam consumption follow the usual pattern (figures $1 \mathrm{la}$ and $1 \mathrm{lb}$ ). Total building energy shows a broad minimum for SC from 0.6 to 1.0

(figure llc). However, the percentage of overheated hours is cut in half going from $\mathrm{SC}=0.6$ to $\mathrm{SC}=0.4$ (figures $1 \mathrm{ld}$ and $1 \mathrm{le}$ ).

Examination of the economic results, tables $9 \mathrm{a}$ through $9 \mathrm{~d}$, shows the SC of 0.2 to be most favorable for summer-only cooling, and SC of 0.1 most favorable for all-year cooled buildings. The low U-factor, $\$ 6 / \mathrm{ft}^{2}-30$ year life, all-year cooling case is cost-effective at the lower shading coefficients.

\subsection{CHICAGO}

Electric and steam consumption follow the usual pattern (figures 12a and $12 \mathrm{~b}$ ). Total building energy is minimum at $\mathrm{SC}=1.0$, but does not change much between $\mathrm{SC}=0.6$ to 1.0 (figure $12 \mathrm{c}$ ). The percent hours of overheating drops off sharply for SC below 0.6 (figures $12 \mathrm{~d}$ and $12 \mathrm{e}$ ).

Tables $10 a$ through $10 d$ indicate a SC of about 0.4 to be most cost-effective for summer-only cooling. A SC of 0.1 is best for all-year cooling. The $\$ 1 / \mathrm{ft}^{2}-10$ year life case has the best savings-to-investment ratio; the $\$ 3 / \mathrm{ft}^{2}-20$ year life cases and a few of the $\$ 6 / \mathrm{ft}^{2}-30$ year life cases also have positive paybacks, for the lower U-factor, particularly for the all-year cooling case. It is interesting to note that for summer-only cooling the $\$ 6 / \mathrm{ft}^{2}$ case pays off only for higher SC indicating that the heating impacts of the low U-factor are responsible for the savings.

\subsection{BOSTON}

Electric and steam consumption follow the usual pattern (figures 13a and 13b). Total building energy is minimum for SC of 1.0 , but changes little between SC 0.6 to 1.0 (figure 13c). Overheating falls off sharply below SC of 0.6 (figures $13 \mathrm{~d}$ and $13 \mathrm{e}$ ). Tables 1la through 1ld indicate a SC of 0.4 to 0.6 to be most cost-effective for summer-only cooling, with greater savings for the lower U-factor. A SC of 0.1 is best for all-year cooled buildings. A few of the $\$ 6 / \mathrm{ft}^{2}-30$ year life, low U-factor cases shows a savings-to-investment ratio of 1.0 or greater, the minimum required for cost-effectiveness. 


\subsection{SAN JOSE}

Electric and steam consumptions follow the usual pattern (figures $14 \mathrm{a}$ and 14b). Figure $14 \mathrm{c}$ shows that total building energy is minimum for $\mathrm{SC}=0.6$, but fairly level between SC of 0.4 to 0.8 . However, figures $14 \mathrm{~d}$ and $14 \mathrm{e}$ show that significant overheating would be expected for SC greater than 0.2

Tables $12 \mathrm{a}$ through $12 \mathrm{~d}$ show that the $\$ 1 / \mathrm{ft}^{2}-10$ year life case with $\mathrm{SC}=0.2$, $\mathrm{U}=0.50$ is the only cost-effective alternative for summer-only cooling. Other cases are not cost-effective because the mild climate of San Jose does not produce large, expensive heating and cooling loads. Comfort may be the major selection criteria for a location such as this. 



\section{CONCLUSIONS}

The results of this investigation indicate that solar shading can be effective in reducing heat transfer and solar heat gain into buildings. Solar shading strategies, such as solar screens, can also reduce building annual energy consumption and improve comfort conditions. The economic analysis indicates that solar shading can be cost-effective, dependent upon the energy performance, first cost and expected life of the shading system. Detailed information on the most effective shading strategy varies for different climatic locations.

In all cases, solar shading increased heating energy consumption and decreased cooling energy consumption. A net energy savings occurred if the cooling energy decrease exceeded the heating energy increase. A net dollar savings can occur if the cost of cooling decreased more than the increase in cost of heating •

For a building which uses cooling all year, the most cost-effective shading coefficient was 0.1 , and savings were much greater than for an equivalent building using summer-only cooling.

For a building which is cooled only in summer, in most cases the minimum energy usage and the minimum energy cost would not be obtained at the same combination of shading device characteristics. In a majority of cases, the most costeffective shading device had a lower shading coefficient than the most energy efficient shading device due to the relative costs of heating and cooling energy •

For summer-cooled buildings, the lower U-factor was best on an energy and economic basis, but caused a slight increase in overheating in perimeter areas. The control of overheating usually required a shading coefficient of less than 0.5. In cooling-dominated climates, energy, economic, and comfort considerations all favored low shading coefficients. In climates with significant heating loads, improved comfort conditions required shading coefficients slightly lower than the most cost-effective, which in turn were lower than the most energy effective.

The economic results were more favorable for the lower cost-short life option $\left(\$ 1 / \mathrm{ft}^{2}-10\right.$ year 1 ife) than for the $\$ 3 / \mathrm{ft}^{2}-20$ year life option, although both were usually cost-effective, at least for the low $U$-factor $(U=0.50)$ cases The $\$ 6 / \mathrm{ft}^{2}-30$ year life case was rarely favorable, except for the colder climates. 


\section{REFERENCES}

1. Kusuda, T. and Collins, B. L., "Simplified Analysis of Thermal and Lighting Characteristics of Windows: Two Case Studies," National Bureau of Standards, BSS 109; 1978.

2. Owens, P. G. T., "Analysis of the Energy Requirement of Buildings with Particular Reference to the Window," Glass in Buildings Conference, International Council for Building Research, Studies and Documentation (CIB) ; 1977 .

3. King, W. J., "High Performance Solar Control Office Windows," Lawrence Berkeley Laboratory Report 7825, 1977.

4. Collins, B. L., "Windows and People: A Literature Survey," Nationa1 Bureau of Standards, BSS 70, 1975.

5. Bitterice, M. G. and McKinley, R. W., "Use Solar Daylight and Heat from Windows to Save Fossil Fuel," PPG Industries, Inc., 1978.

6. Treado, S. and Kusuda, T., "Daylighting, Window Management Systems and Lighting Controls," NBSIR Sept. 80-2147, December 1980.

7. Treado, T., Gillette, G., Kusuda, T., "Evaluation of the Daylighting and Energy Performance of Windows, Skylights and Clerestories," National Bureau of Standards, NBSIR 83-2726, June 1983.

8. Ruegg, R. T. and Chapman, R. E., "Economic Evaluation of Windows in Buildings: Methodology," National Bureau of Standards, BSS 119, 1979.

9. Barakat, S. A., "Solar Heat Gain through Windows in Canada," National Research Council of Canada, Division of Building Research, Paper No. 944, October 1980.

10. Hopkinson, R., "A Note on the Use of Indices of Glare Discomfort for a Code of Lighting," Transactions of the Illuminating Engineering Society, Vo1. 25, No. 3, 1960 .

11. Rubin, A., Collins, B., Tibbot, R., "Window Blinds as a Potential Energy Saver - A Case Study," National Bureau of Standards, BSS 112, May 1978.

12. Ozisik, N., Schutrum, L., "Heat Flow Through Glass with Roller Shades," ASHRAE Transactions, Vo1. 65, p. 697, 1959.

13. ASHRAE Handbook of Fundamentals, published by ASHRAE, New York, 1981.

14. Yellott, J. I., "Shading Coefficients and the Sun-Control Capability of Single-Glazing," ASHRAE Transactions, Vo1. 72, Part 1, 1966.

15. Yellott, J., "Effect of Louvered Sun Screens Upon Fenestration Heat Loss," ASHRAE Transactions, No . $2227,1972$. 
16. Parmelee, G., Anbele, W., Vild, D., "The Shading of Sunlit Glass," ASHRAE Transactions, Vo1. 59, p. 221, 1953.

17. Treado, S., Barnett, J., Kusuda, T., "Energy and Cost Evaluation of Solar Window Film Use in an Office Building," National Bureau of Standards Technical Note 1174, March 1983.

18. Ito, N., Kimura, K., and Oka, J., "A Field Experiment Study on the Convective Heat Transfer Coefficient on the Exterior Surface of a Building," Transactions of the Architectural Institute of Japan, 1968.

19. DOE-2 Users Guide, prepared by the Lawrence Berkeley Laboratory and Los Alamos Scientific Laboratory for the U.S. Department of Energy under Contracts W-745-ENG-48, 1979.

20. National Climatic Center, 1976, Tape Reference Manual "Test Reference Year," National Climatic Center, Asheville, N.C., Also published in the ASHRAE Journal, February 1977, p. 47.

21. Ruegg, R. T., "Life-Cycle Costing Manual for the Federal Energy Management Programs," National Bureau of Standards Handbook 135, December 1980. 
APPENDIX A

\section{A.1 DESCRIPTION OF BUILDING MODEL}

- Infiltration was simulated using air change (AC) method - the rates and profile were as follows:

\section{Basement - none}

2. Garage .8AC - al1 hours

3. All Floors - .6AC when main fans are off for perimeter zones none for interior zone

4. Lobby - 2.0AC peak during entry and exit of occupants

- Partitions between zones were treated as having a U factor of $5.68 \mathrm{~W} /\left(\mathrm{m}^{2}{ }^{\circ} \mathrm{K}\right)\left(1.0 /\left(\mathrm{ft}^{2} \mathrm{hr}^{\circ} \mathrm{F}\right)\right.$ representing a fairly free convective flow with doors open.

- Lighting levels were simulated at $21.5 \mathrm{~W} / \mathrm{m}^{2}\left(2 \mathrm{~W} / \mathrm{ft}^{2}\right)$ in office areas and $10.8 \mathrm{~W} / \mathrm{m}^{2}\left(1 \mathrm{~W} / \mathrm{ft}^{2}\right)$ in Basement and Garage.

- Equipment levels (typewriters, copy machines, CRTs, etc.) were simulated at $16.1 \mathrm{~W} / \mathrm{m}^{2}\left(1.5 \mathrm{~W} / \mathrm{ft}^{2}\right)$ in office areas.

- Computers and associated air-conditioning systems were simulated as a single energy user at $150 \mathrm{~kW}$ for all hours.

- Custom weighting factor method was used to generate weighting factors for the simulation.

- Average domestic hot water load was estimated at $0.88 \mathrm{~kW}(3000 \mathrm{Btu} / \mathrm{hr})$.

- Thermostat setpoints simulated were as follows:
1. Basement
$-18.3^{\circ} \mathrm{C}\left(65^{\circ} \mathrm{F}\right)$
2. Garage
$-12.8^{\circ} \mathrm{C}\left(55^{\circ} \mathrm{F}\right)$
3. Offices
- $18.3^{\circ} \mathrm{C}\left(65^{\circ} \mathrm{F}\right)$ for heating $25.6^{\circ} \mathrm{C}\left(78^{\circ} \mathrm{F}\right)$ for cooling

- Elevator loads were included in the simulation.

- Occupant loads were simulated using standard operating schedules. 
- Air handling system type and fan operating hours input were as follows:

1. Basement

2. Garage

3. Perimeter Offices - Two pipe fan coil heating only October 15 through May 15 - cooling only May 16 to October 14 (summer-only cooling) or year round (a11-year cooling)

Fan hours on at 0600 - off at 1700 weekdays only off weekends and holidays

4. Interior Offices - Interior Offices - Reheat fan system heating only October 15 through May 15 - cooling on1y May 16 through October 14 (summer-only cooling) or year round (all-year cooling)

Fan hours on at 0600 - off at 1700 weekdays off weekends and holidays

\section{Assumptions or Simplifications Used for Preparing Input}

- The DOE-2 program can only accept three (3) separate plenum inputs. The ground floor, first floor and lobby were all simulated as being served by a single interior air system with a common return air plenum. This left a plenum for the typical floors ( 2 through 5 ), and another for the top floor (6).

- Since the second floor was treated as a typical floor with a typical plenum, the conference rooms over the lobby areas were treated as office space.

- The penthouse equipment room was not input as an unconditioned space. The roof areas of the sixth floor plenum excluded the surface area in contact with the penthouse.

- A standard outdoor reset of supply air temperatures on the reheat fan systems was input to simulate the combined effect of manual daily settings of preheat, outside air, and chilled water reset.

- A minimum percent outside air for the reheat fan systems was input as 5 percent even though the operator maintains dampers "closed" in very cold weather. The 5 percent was used to reflect leakage of dampers in the closed position.

- The chilled water plant in the study building (B) also serves an adjacent building (A). To simulate building $B$ two chillers were input 
of a size to accommodate building B's load, with no attempt to evaluate the loading of building $A$.

- The exhaust fans in the building were assumed to have the same operating schedules as supply units. The fan static air pressure and fan efficiencies were combined into a single input. 


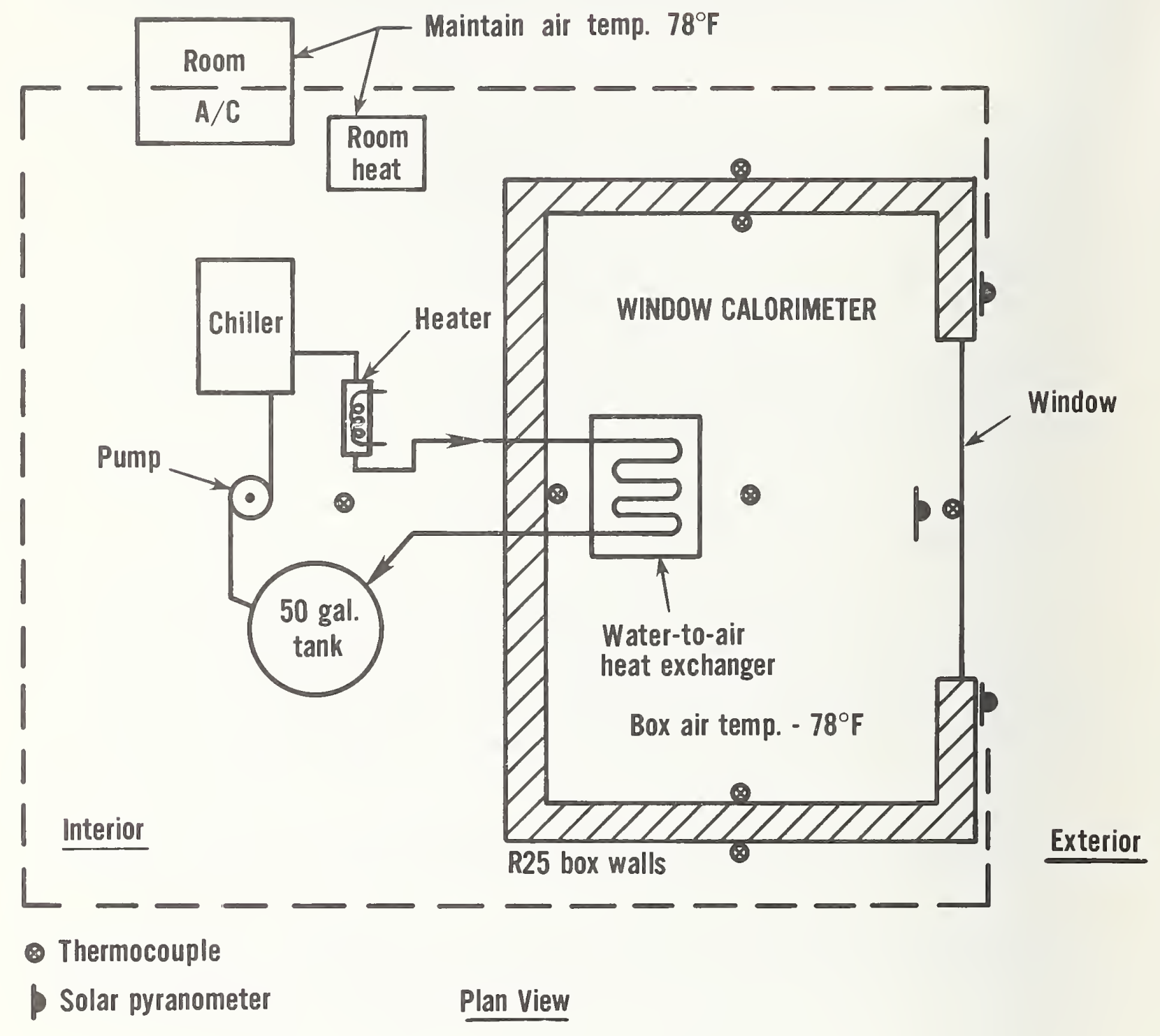

Figure 1. Schematic diagram of window calorimeter 


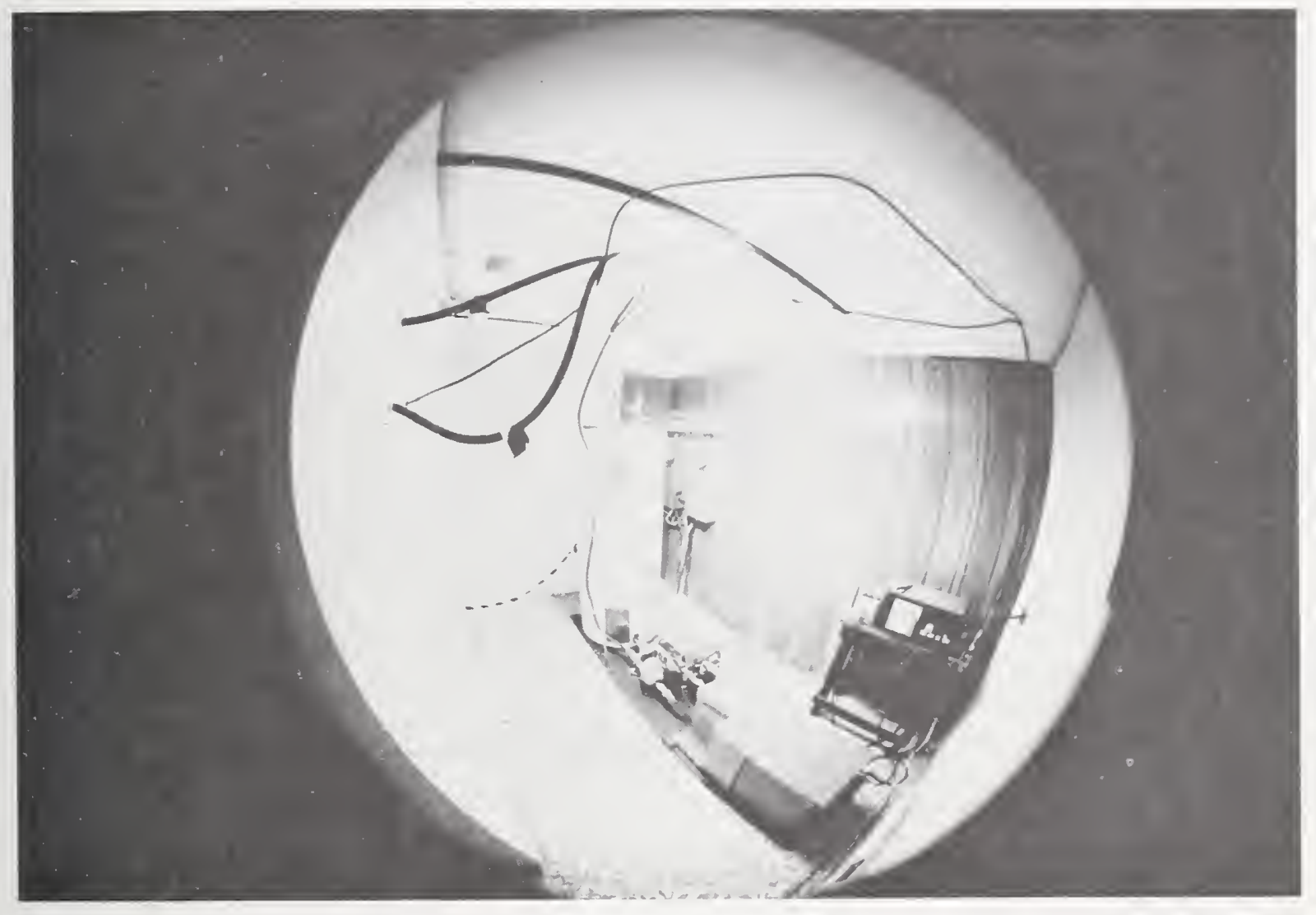

Figure 2. Photograph of window calorimeter apparatus 


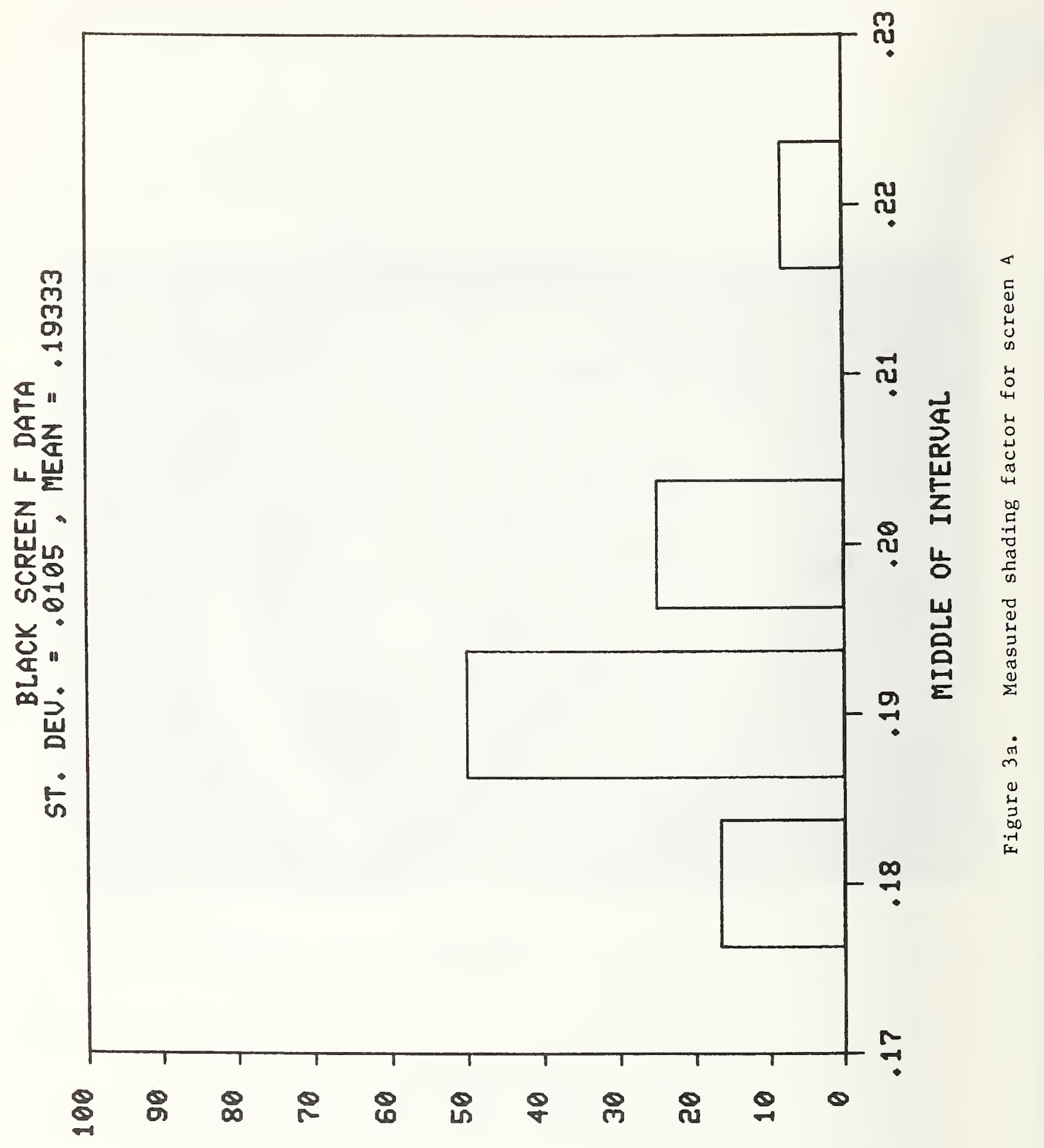

$\wedge$

ดய 


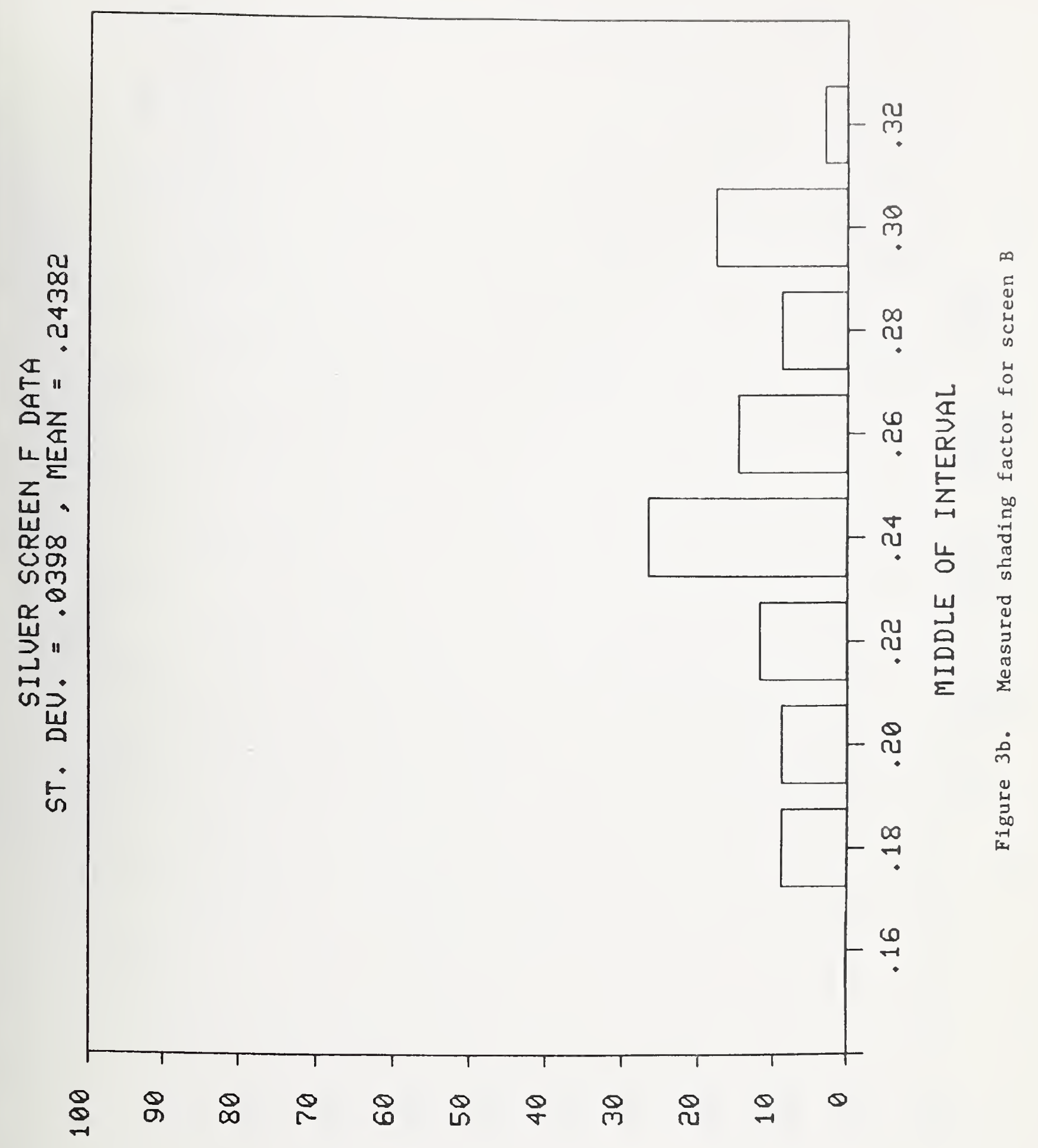

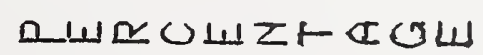




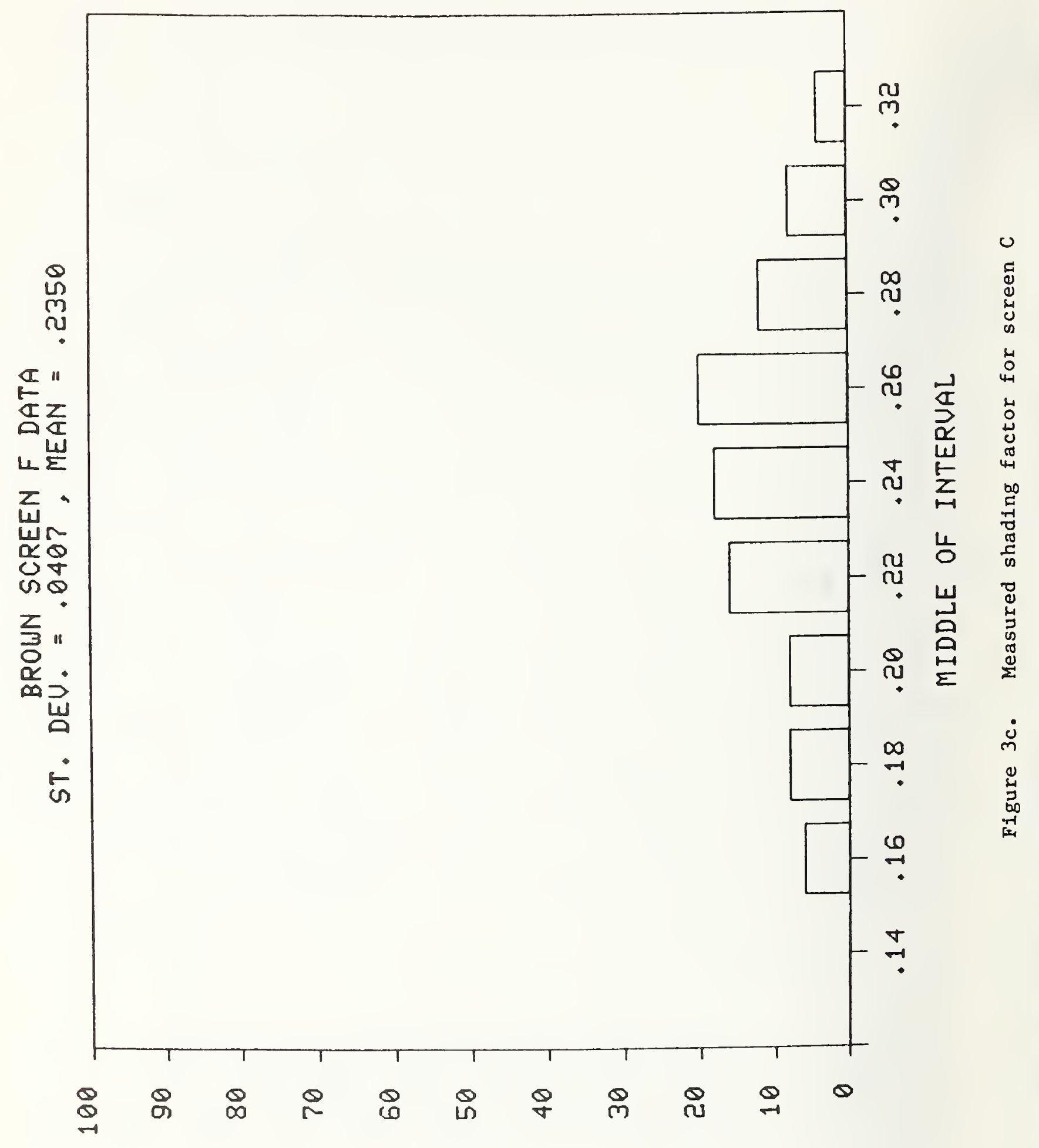

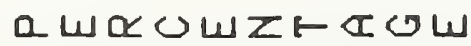




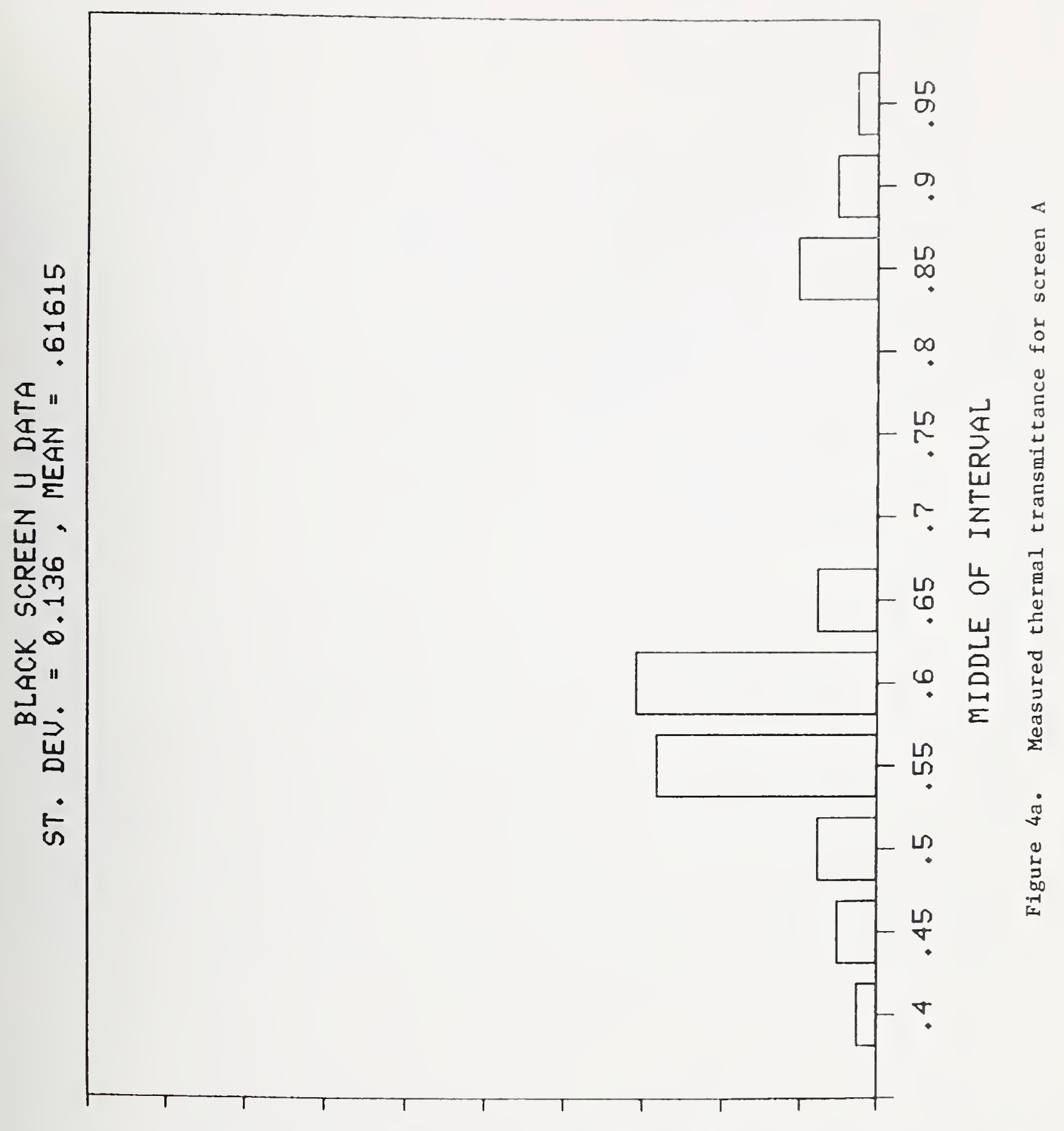

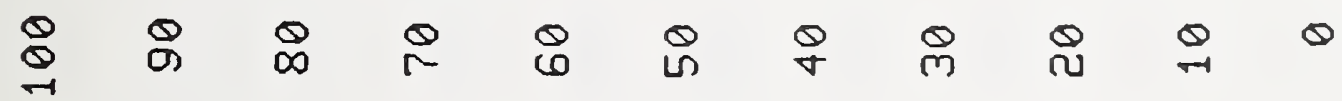

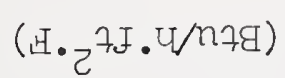




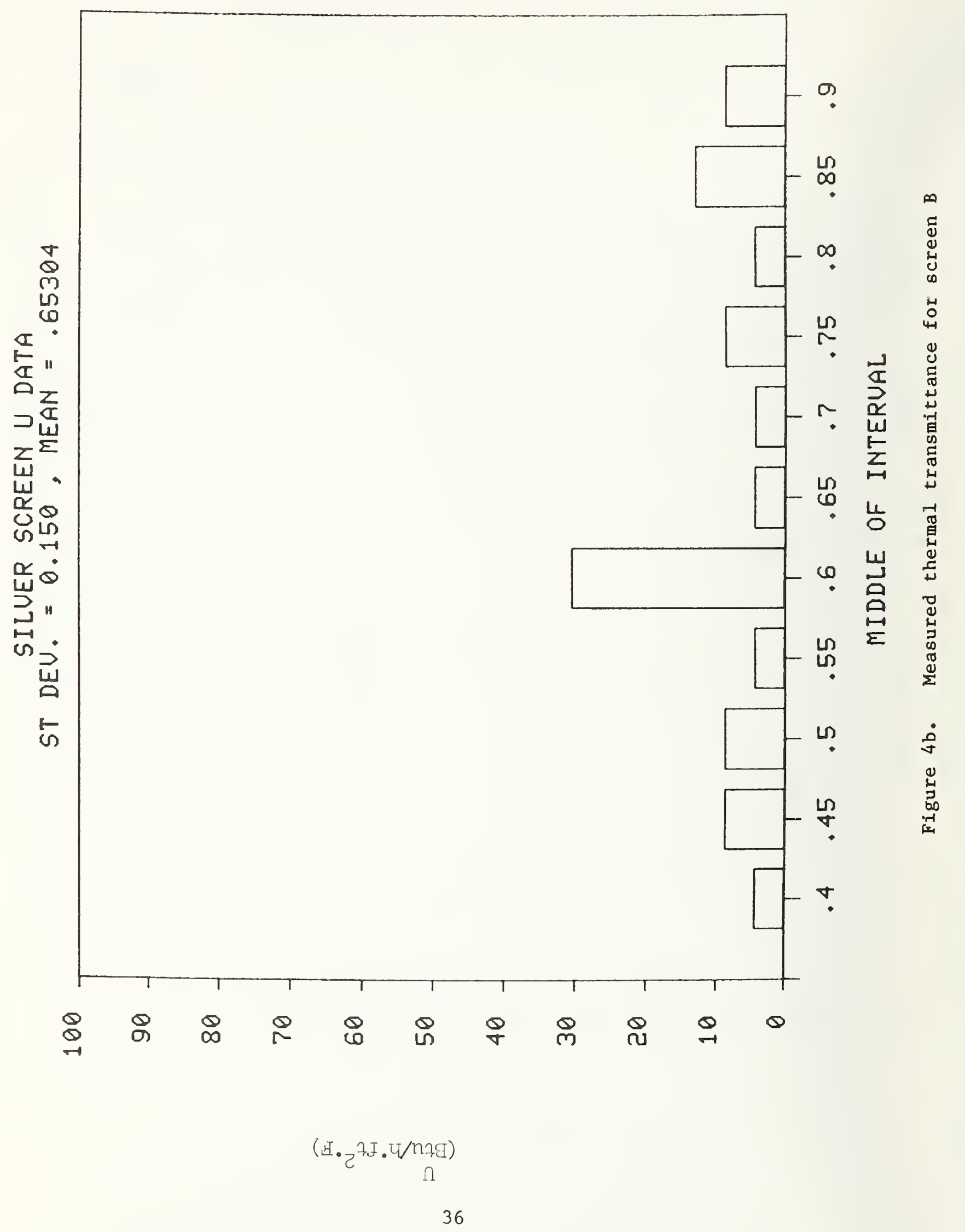




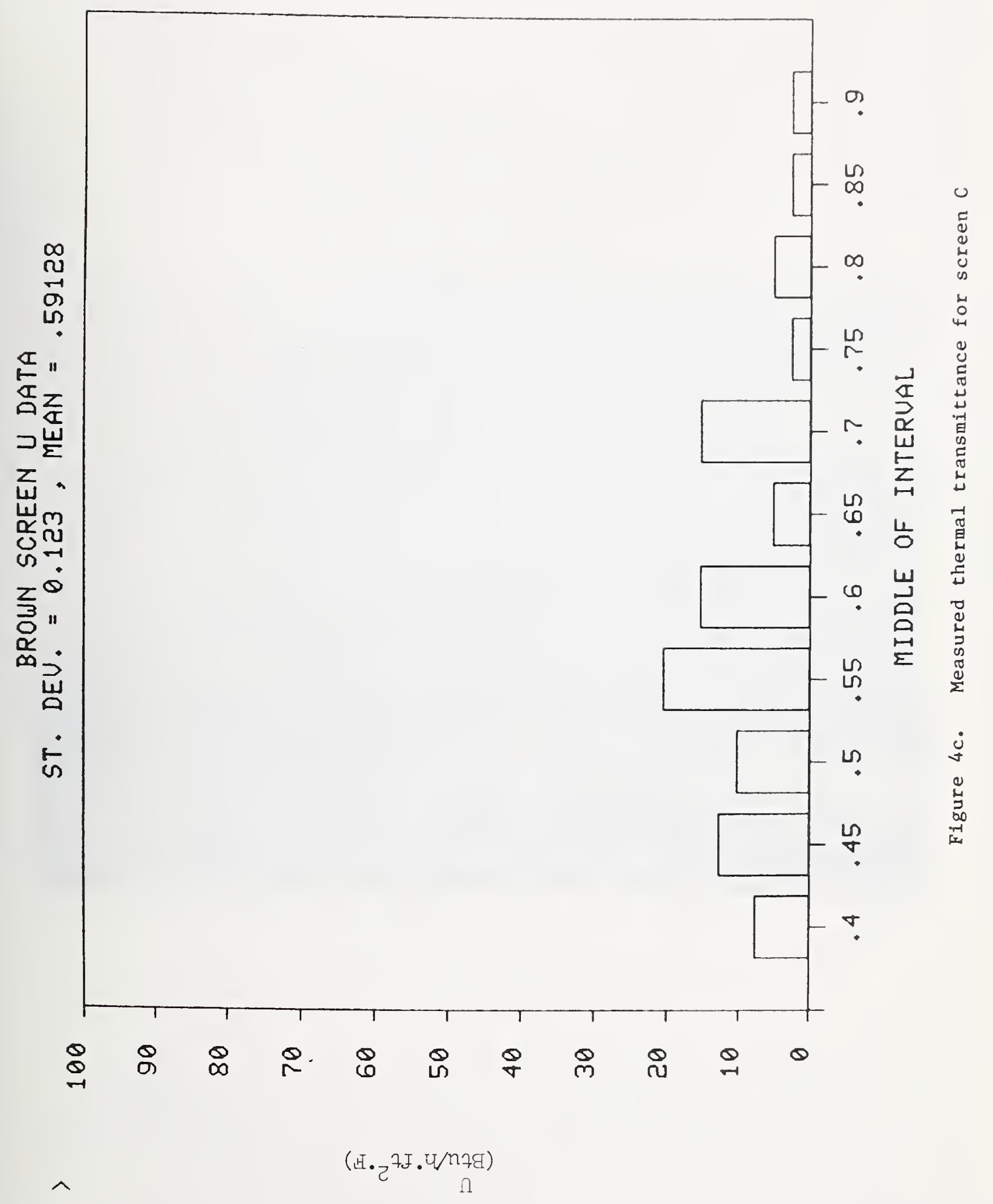




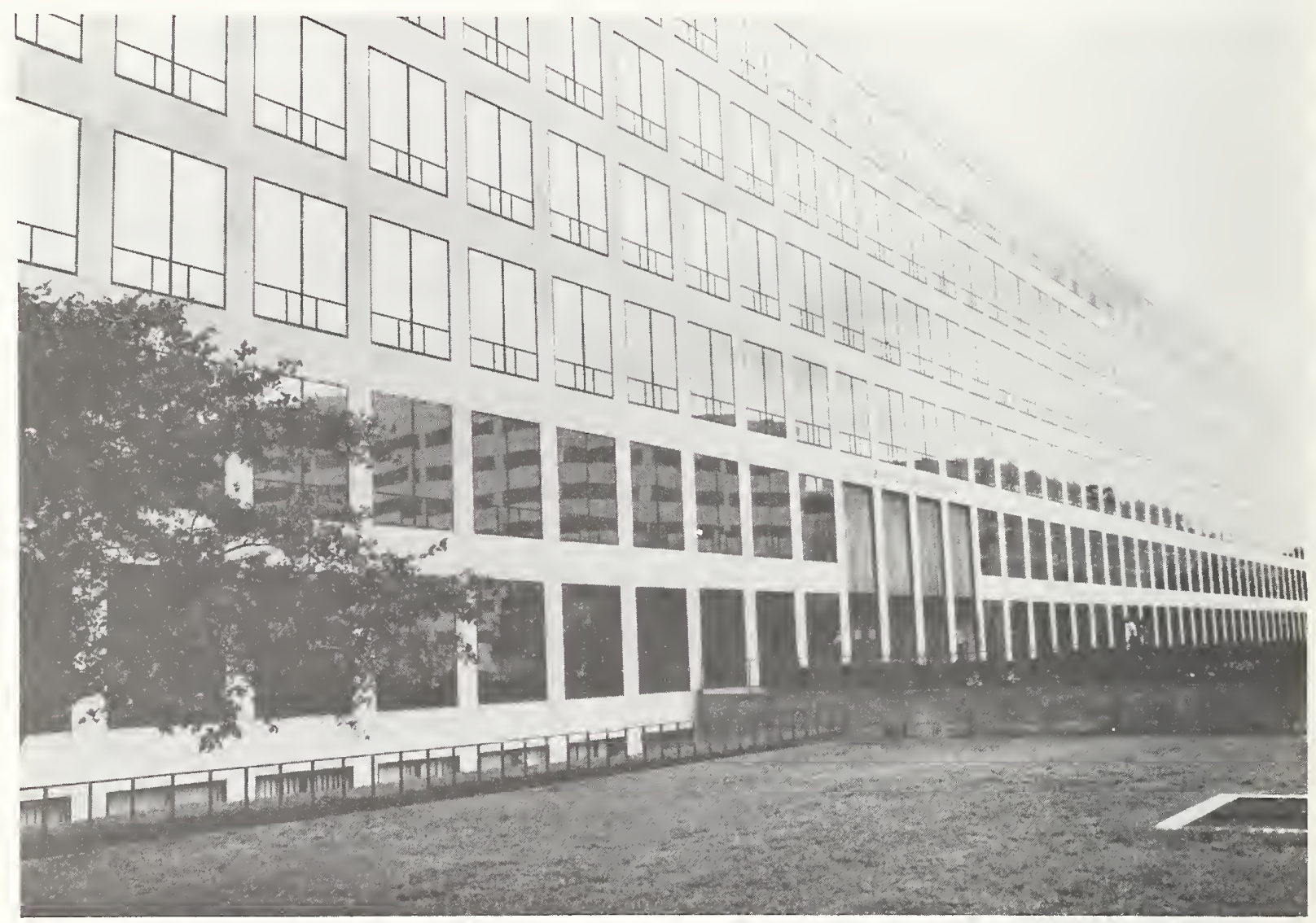

Figure 5. Photograph of study building 


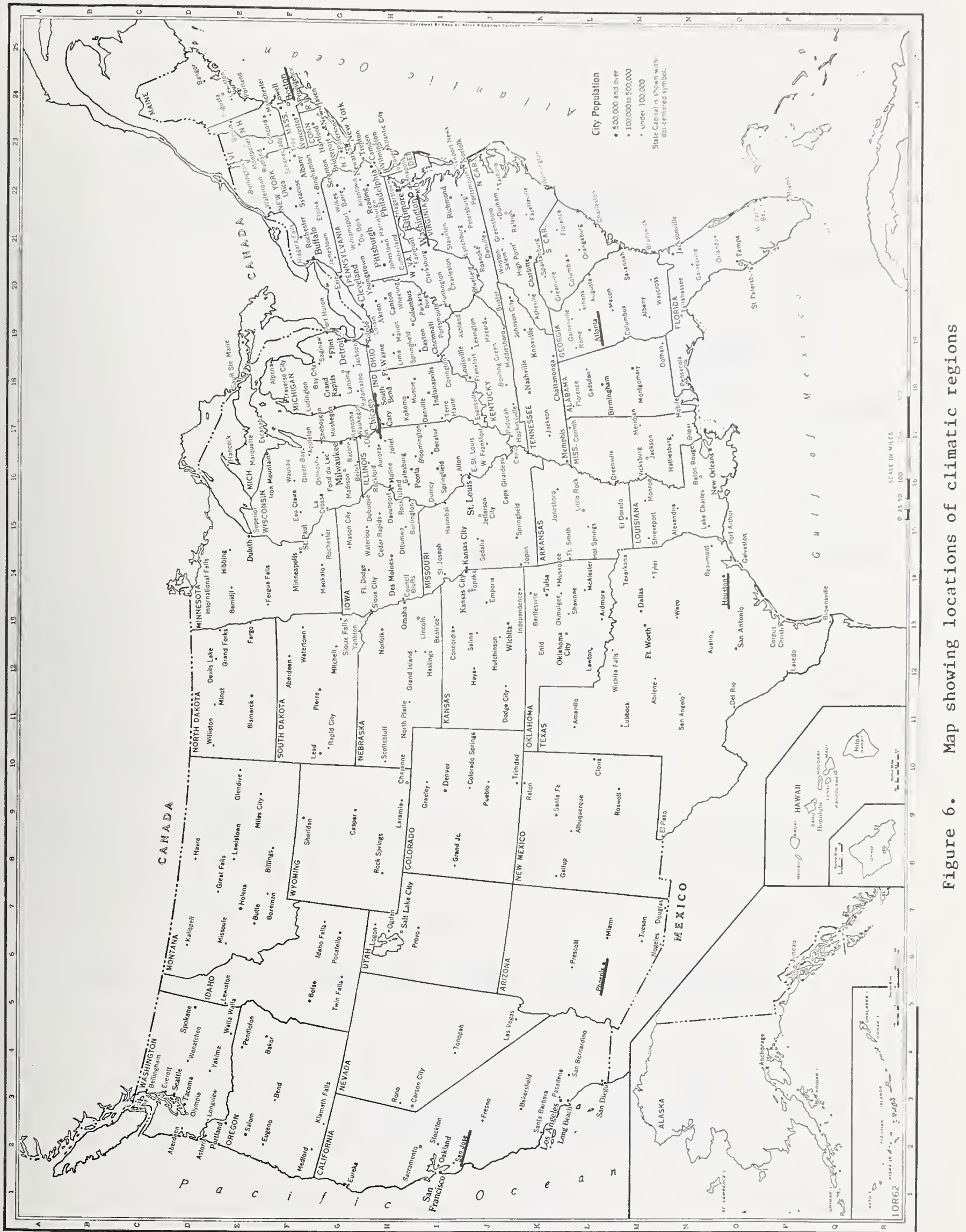




\section{BUILDING MONTHLY ENERGY CONSUMPTION}

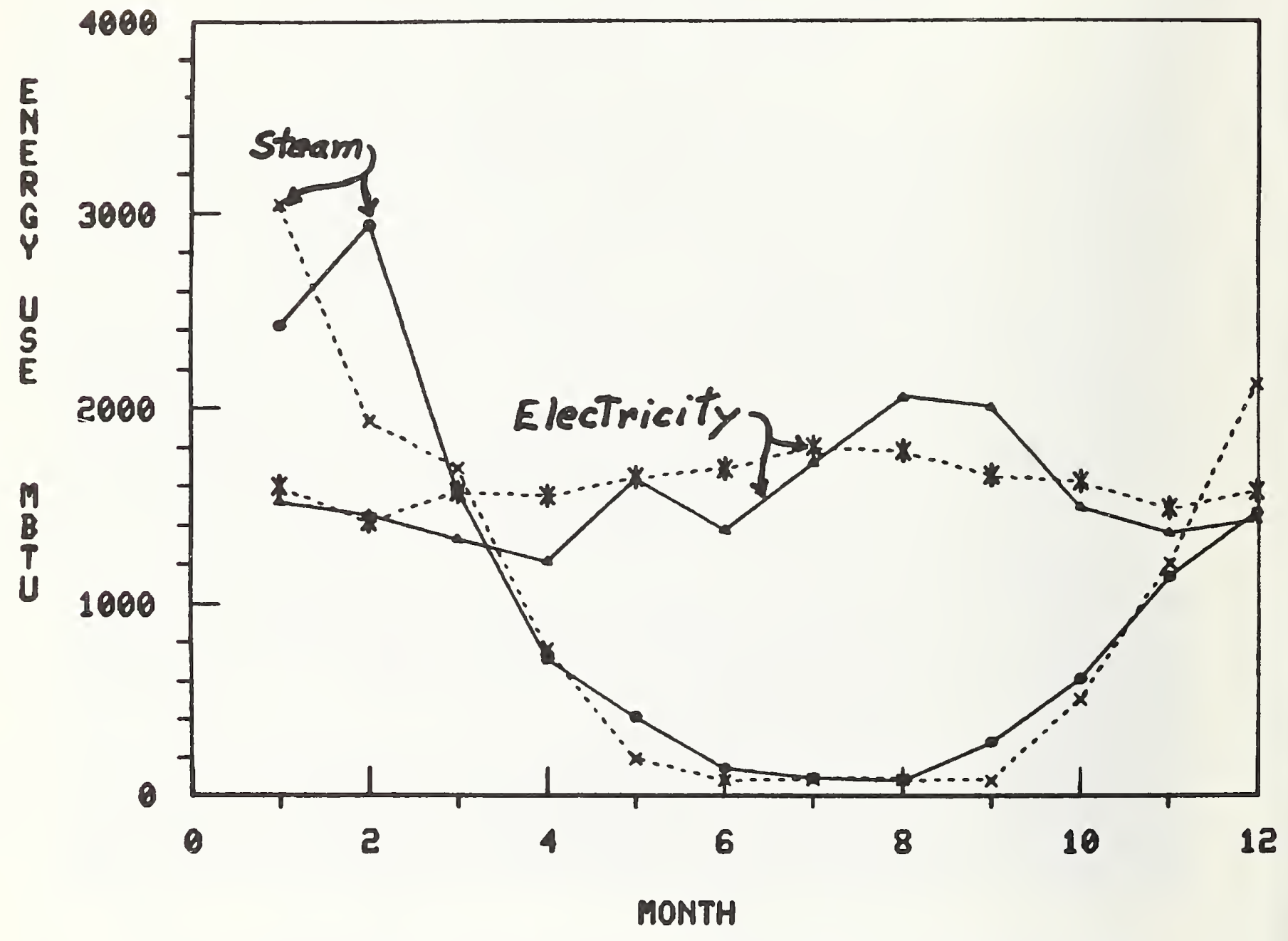

MEASURED = SOLID LINE, PREDICTED = DOTTED LINE

Figure 7. Monthly energy consumptions for actual and simulated building, for Washington, D.C., clear glass, summer-only cooling 


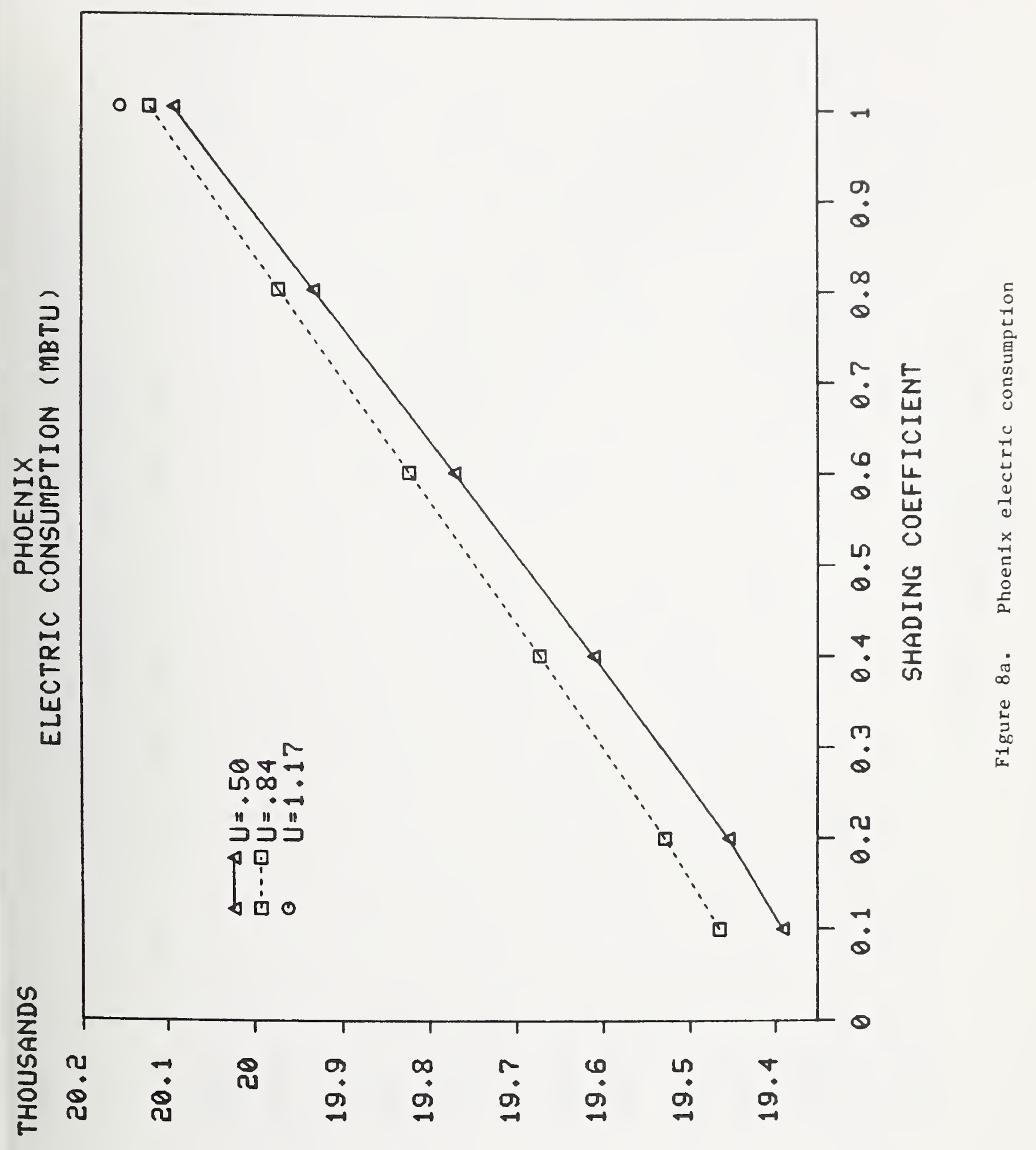

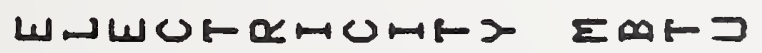




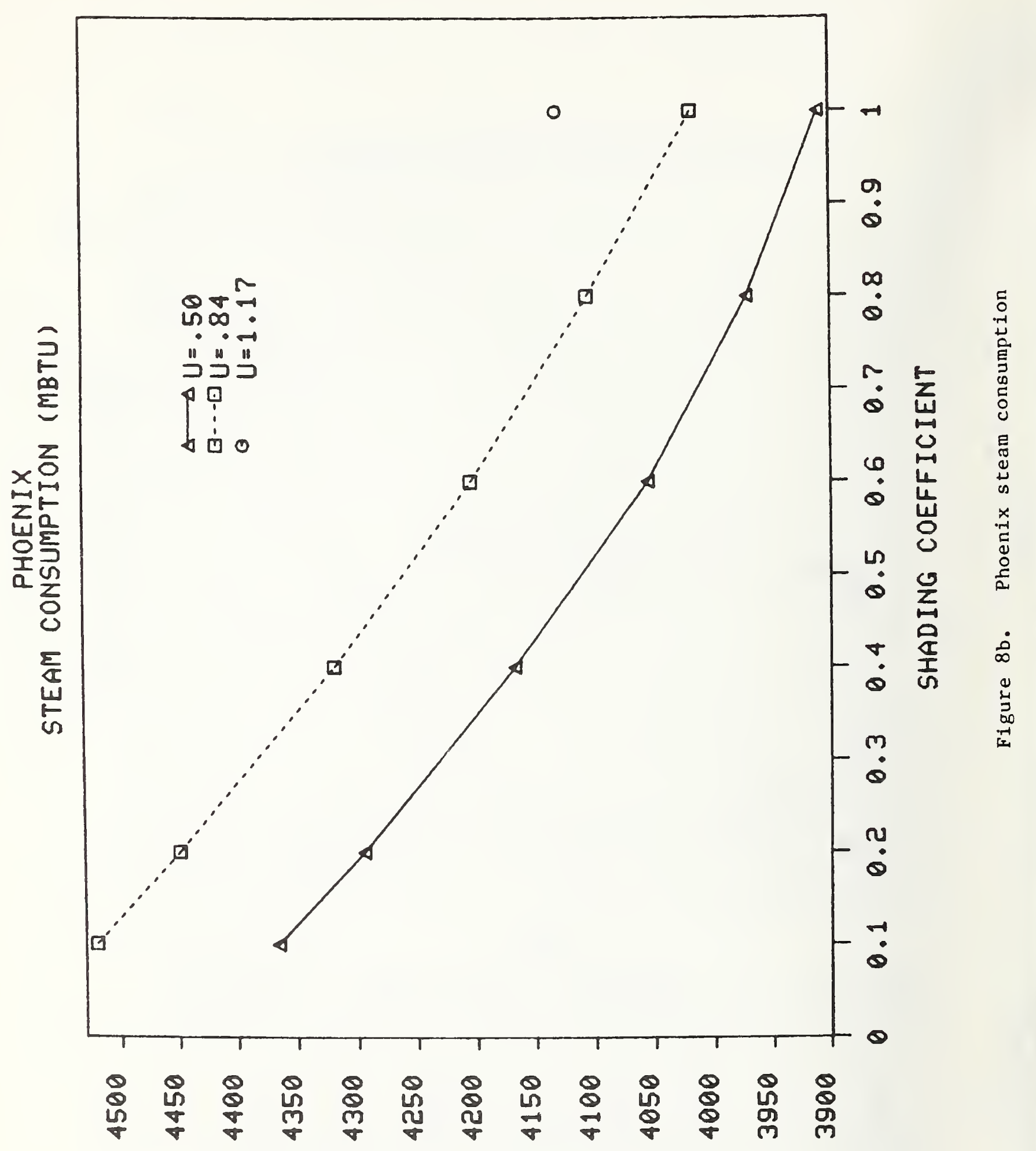

जtWवE 


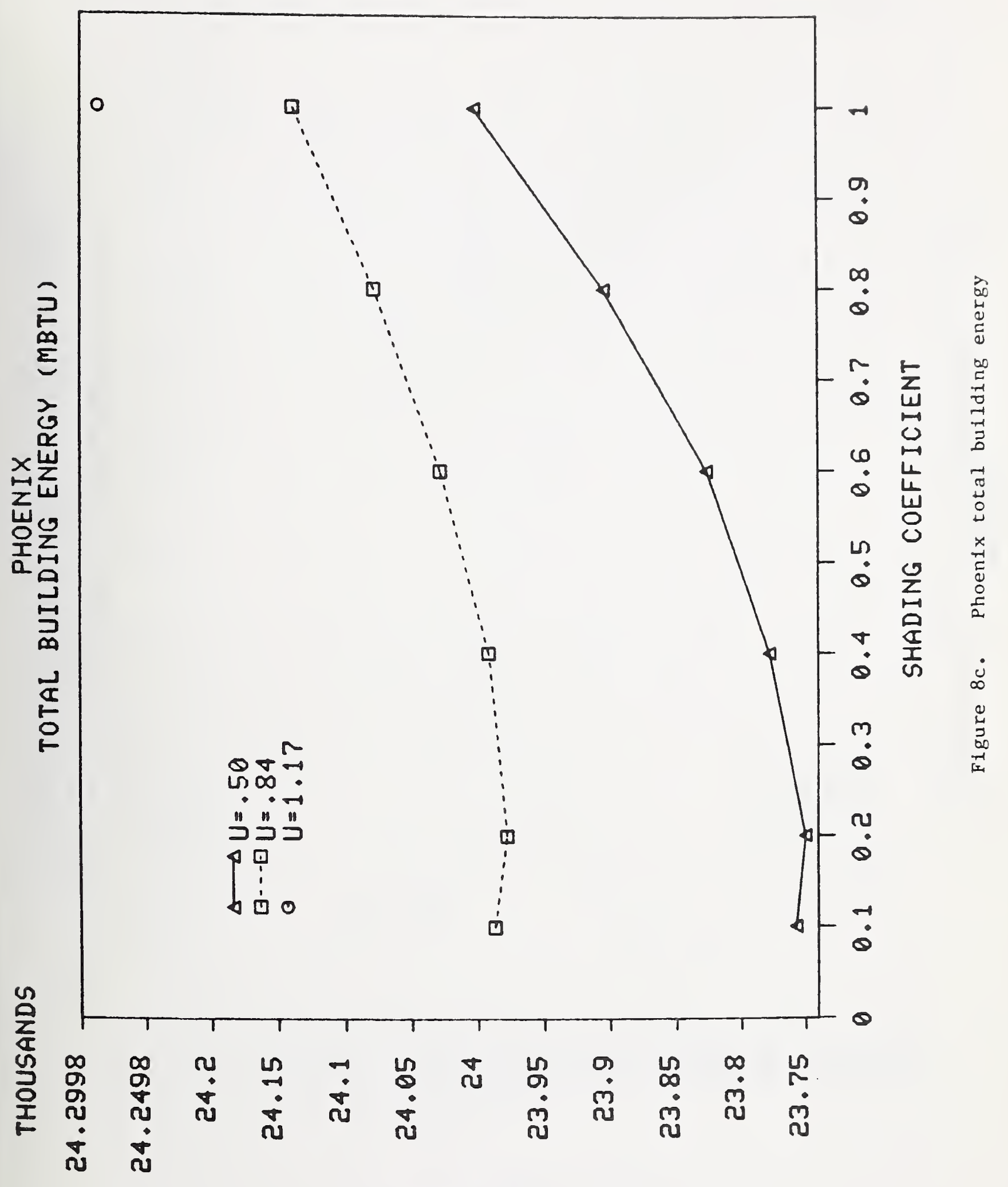

HOR 


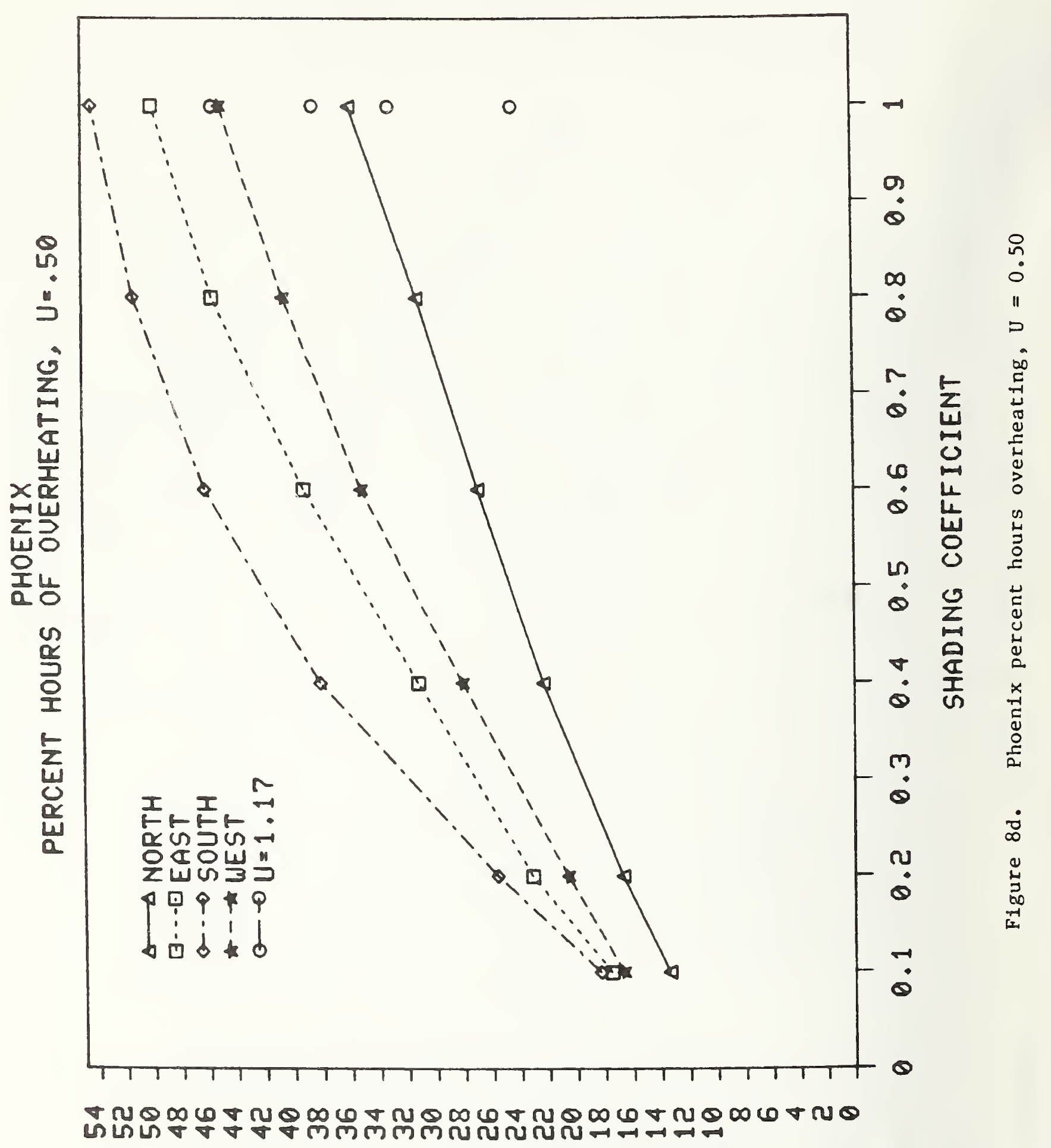

aயवणแzเ 


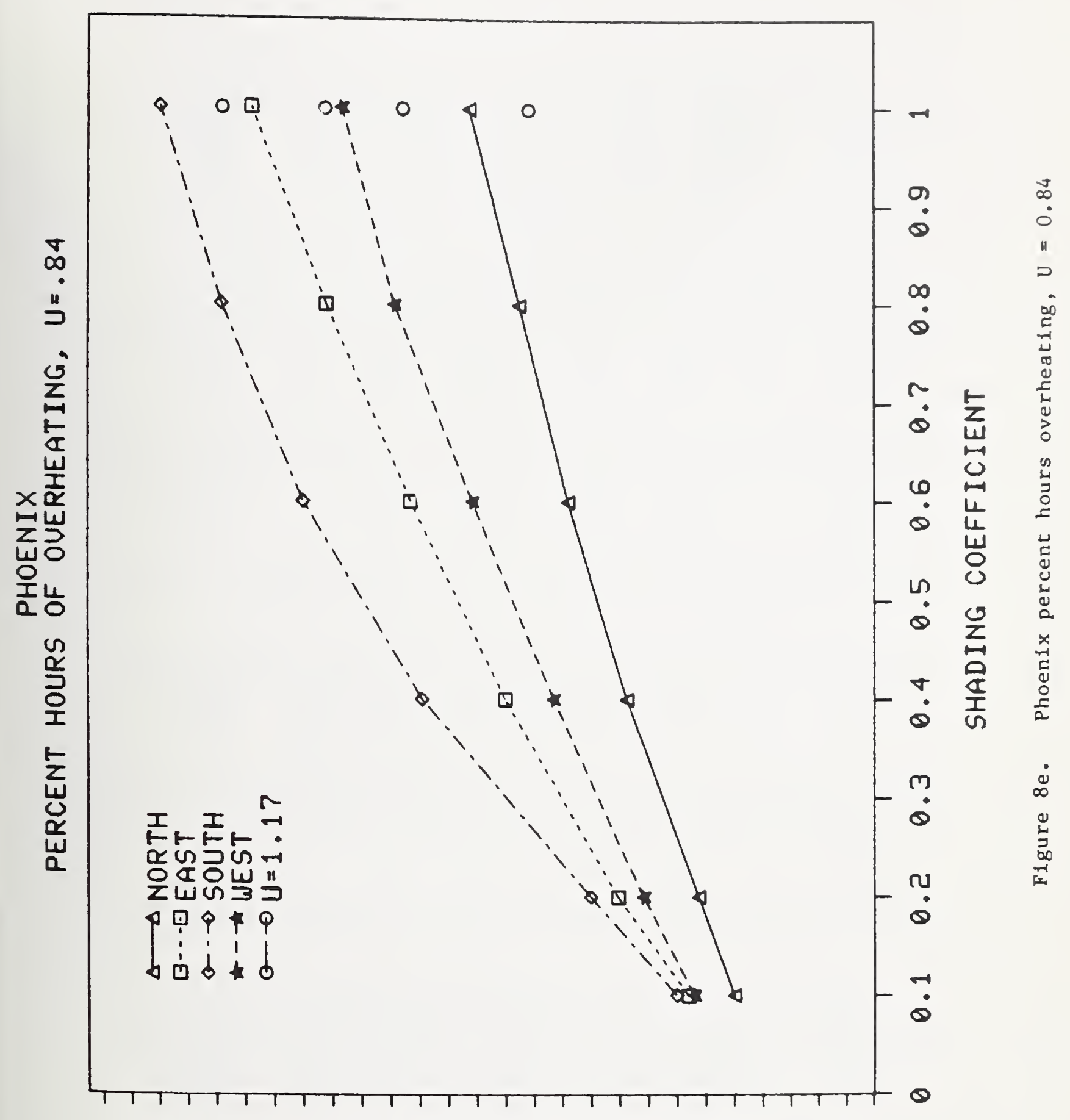

ฟ

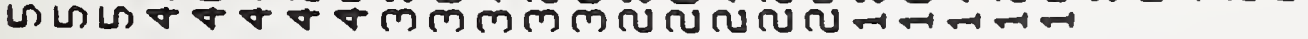


Iable 6a. Cost-effectiveness for Phoenix $U=0.50$, Summer-onlv Cooling

FIRST YEAR ENERGY SAVINGS (DOLLARS) FOR SOLAR SCREENS $(U=0.50)$

\begin{tabular}{|c|c|c|c|c|c|c|}
\hline $\begin{array}{l}\text { HEAT ING ENERGY } \\
+* * * * * * \cdots * * *\end{array}$ & $\begin{array}{l}S C=0.1 \\
* \neq * \ldots\end{array}$ & $\begin{array}{l}S C=0.2 \\
* \ldots\end{array}$ & $\begin{array}{l}S C=0.4 \\
* * *\end{array}$ & $\begin{array}{l}S C=0.6 \\
* * * *\end{array}$ & $S C=0.8$ & $\begin{array}{l}S C=1.0 \\
* \ldots\end{array}$ \\
\hline $\begin{array}{l}\text { GAS } \\
\text { OIL } \\
\text { STEAM }\end{array}$ & $\begin{array}{l}12274 . \\
11249 . \\
10822 .\end{array}$ & $\begin{array}{l}11598 . \\
10885 . \\
10589 .\end{array}$ & $\begin{array}{l}9652 . \\
9494 . \\
9429 .\end{array}$ & $\begin{array}{l}7502 . \\
7835 . \\
7973 .\end{array}$ & $\begin{array}{l}5142 . \\
5840 . \\
6130 .\end{array}$ & $\begin{array}{l}2659 . \\
3829 . \\
4033 .\end{array}$ \\
\hline ASSUMPTIONS: & $\begin{array}{l}\text { ELECTRICITY } \\
\text { HEATING FUEL }\end{array}$ & $\begin{array}{l}\cos T=\$ \\
\cos T=\$\end{array}$ & $\begin{array}{l}\$ .062 / K W H \\
5.023 \text { (GAS) }\end{array}$ & $.038(0 I L)$. & . . .045/STE & $E A M) / K W H$ \\
\hline PAY-8ACK PER & ICDS (YEARS) & FOR SOLAR & R SCREENS & $(\cos T=\$ 1.0 /$ & /SO. FT. & $U=0.50)$ \\
\hline $\begin{array}{l}\text { HEATIING ENERGY } \\
\text { H }^{*} *^{*} * *^{*} * * *\end{array}$ & $S C=0.1$ & $\begin{array}{l}S C=0.2 \\
* * * \ldots *\end{array}$ & $\begin{array}{l}S C=0.4 \\
* * * * *\end{array}$ & $\begin{array}{l}S C=0.6 \\
* * * * *\end{array}$ & $\begin{array}{l}S C=0.8 \\
\ldots \ldots\end{array}$ & $\begin{array}{l}S C=1.0 \\
* * * *\end{array}$ \\
\hline $\begin{array}{l}\text { GAS } \\
\text { OIL }\end{array}$ & $\begin{array}{l}4.0 \\
4.0 \\
5.0\end{array}$ & $\begin{array}{l}4.0 \\
4.0 \\
5.0\end{array}$ & $\begin{array}{l}5.0 \\
5.0 \\
5.0\end{array}$ & $\begin{array}{l}7.0 \\
6.0 \\
6.0\end{array}$ & $\begin{array}{r}10.0 \\
9.0 \\
8.0\end{array}$ & $\begin{array}{l}29.0 \\
16.0 \\
14.0\end{array}$ \\
\hline
\end{tabular}

SAVINGS-TO-INVESTMENT RATIOS FOR SOLAR SCREENS (COST $=\$ 1.0 / 50$. FT. U U $=0.50$ )

$\begin{array}{crrrrrr}\text { HEATING ENERGY } & S C=0.1 & S C=0.2 & S C=0.4 & S C=0.6 & S C=0.8 & S C=1.0 \\ \text { GAS } & 2.4 & 2.3 & 1.9 & 1.5 & 1.0 & .6 \\ \text { OIL } & 2.2 & 2.1 & 1.9 & 1.5 & 1.1 & .7 \\ \text { STEAM } & 2.1 & 2.1 & 1.8 & 1.6 & 1.2 & .8\end{array}$

10 YEAR PRESENT WORTH FACTOR $=9.2$ (GAS), 8.O(OIL), 8.7(STEAM), 8.3(ELEC) MATERIAL \& INSTALLATICN COST $=\$ 42000$.

PAY-BACK PERIODS (YEARS) FOR SOLAR SCREENS (COST $=\$ 3,0 / 50$. FT, U U=0.50)

$\begin{array}{crrrrrr}\text { HEATING ENEP.GY } & \text { SC=0.1 } & \text { SC=0.2 } & \text { SC=0.4 } & S C=0.6 & S C=0.8 & S C=1.0 \\ \text { GAS } & 15.0 & 16.0 & 24.0 & >30.0 & >30.0 & >30.0 \\ \text { OIL } & 18.0 & 19.0 & 25.0 & >30.0 & >30.0 & >30.0 \\ \text { SIEAIH } & 19.0 & 20.0 & 25.0 & >30.0 & >30.0 & >30.0\end{array}$

SAVINGS-TO-INVESTMENT RATIOS FOR SOLAR SCREENS (COST $=\$ 3.0 / 50$. FT., U $=0.50$ )

$\begin{array}{crrrrrr}\text { HEATING ENERGY } & S C=0.1 & S C=0.2 & S C=0.4 & S C=0.6 & S C=0.8 & S C=1.0 \\ \text { GAS } & 1.2 & 1.1 & .9 & .7 & .5 & .3 \\ \text { OIL } & 1.1 & 1.0 & .9 & .8 & .6 & .4 \\ \text { STEAM } & 1.0 & 1.0 & .9 & .8 & .6 & .4\end{array}$

20 YEAR PRESENT WORTH FACTOR = 14.3(GAS), 14.8(OIL), 13.6(STEAM), 12.4(ELEC) MATERIAL \& INSTALLATION COST $\approx \$ 126000$.

PAY-EACK PERIODS (YEARS) FOR SOLAR SCREENS (COST $=\$ 6.0 / 50$. FT . U U $=0.50$ )

$\begin{array}{ccccccc}\text { HEATING ENERGY } & S C=0.1 & \text { SC=0.2 } & S C=0.4 & S C=0.6 & S C=0.8 & S C=1.0 \\ \text { GAS } & >30.0 & >30.0 & >30.0 & >30.0 & >30.0 & >30.0 \\ \text { OIL } & >30.0 & >30.0 & >30.0 & >30.0 & >30.0 & >30.0 \\ \text { STEAM } & >30.0 & >30.0 & >30.0 & >30.0 & >30.0 & >30.0\end{array}$

SAVINGS-TO-INVESTMENT RATIOS FOR SOLAR SCREENS (COST $=\$ 6.0 / 5 Q$. FT. U U $=0.50$ )

$\begin{array}{crrrrrr}\text { HEATING ENERGY } & S C=0.1 & S C=0.2 & S C=0.4 & S C=0.6 & S C=0.8 & S C=1.0 \\ \text { GAS } & .7 & .7 & .6 & .4 & .3 & .2 \\ \text { OIL } & .6 & .6 & .5 & .5 & .4 & .3 \\ \text { STEAM } & .6 & .6 & .5 & .5 & .4 & .3\end{array}$

30 YEAR PRESENT WORTH FACTOR $=17.3$ (GAS), 21.3 (OIL), 16.2(STEAM). 14.5(ELEC) MATERIAL \& INSTALLATION COST $=\$ 252000$. 
Table 6b. Cost-effectiveness for Phoenix $U=0.84$, Summer-only Cooling

FIRST YEAR ENERGY SAVINGS (DOLLARS) FOR SOLAR SCREENS $(U=0.84)$

$\begin{array}{ccccccc}\text { HEATING ENERGY } & S C=0.1 & S C=0.2 & S C=0.4 & S C=0.6 & S C=0.8 & S C=1.0 \\ \text { GAS } & 9347 . & 9202 . & 7482 . & 5524 . & 3499 . & 1406 . \\ \text { OIL } & 8144 . & 7813 . & 6662 . & 5204 . & 3610 . & 1900 . \\ \text { STEAM } & 7435 . & 7235 . & 6321 . & 5070 . & 3656 . & 2106 .\end{array}$

ASSUMPTIONS: $\quad$ ELECTR!CITY COST $=\$ .062 / \mathrm{KWH}$

HEATING FUEL COST $=\$ .023($ GAS $), .038(0 I L), .045($ STEAM) $/ \mathrm{KWH}$

PAY-BACK PERIODS (YEARS) FOR SOLAR SCREENS (COST=\$1.0/SO. FT.. U U $=0.84$ )

$\begin{array}{crrrrrr}\text { HEATING ENERGY } & S C=0.1 & S C=0.2 & S C=0.4 & S C=0.6 & S C=0.8 & S C=1.0 \\ \text { GAS } & 5.0 & 5.0 & 7.0 & 10.0 & 19.0 & >30.0 \\ \text { OIL } & 6.0 & 6.0 & 7.0 & 10.0 & 18.0 & >30.0 \\ \text { STEAM } & 7.0 & 7.0 & 8.0 & 11.0 & 17.0 & >30.0\end{array}$

SAVINGS-TO-INYESTMENT RATIOS FOR SOLAR SCREENS (COST= $\$ 1.0 /$ SO. FT., U $=0.84$ )

$\begin{array}{crrrrrr}\text { HEATING ENERGY } & S C=0.1 & S C=0.2 & S C=0.4 & S C=0.6 & S C=0.8 & S C=1.0 \\ \text { GAS } & 1.9 & 1.8 & 1.4 & 1.1 & .7 & .3 \\ \text { OIL } & 1.6 & 1.6 & 1.3 & 1.0 & .7 & .4 \\ \text { STEAM } & 1.4 & 1.4 & 1.2 & 1.0 & .7 & .4\end{array}$

10 YEAR PRESENT WORTH FACTOR = 9.2(GAS), 8.O(OIL), 8.7(STEAM), 8.3(ELEC) MATERIAL \& INSTALLATION COST $=\$ 42000$.

PAY-BACK PERIODS (YEARS) FOR SOLAR SCREENS (COST= $\$ 3.0 / S O$. FT., U=0.84)

$\begin{array}{crrrrrr}\text { HEATING ENERGY } & S C=0.1 & \text { SC=0.2 } & S C=0.4 & S C=0.6 & S C=0.8 & S C=1.0 \\ \text { GAS } & 25.0 & 30.0 & >30.0 & >30.0 & >30.0 & >30.0 \\ \text { OIL } & >30.0 & >30.0 & >30.0 & >30.0 & >30.0 & >30.0 \\ \text { STEAM } & >30.0 & >30.0 & >30.0 & >30.0 & >30.0 & >30.0\end{array}$

SAVINGS-TO-INVESTMENT RATIOS FOR SOLAR SCREENS (COST $=\$ 3.0 / 50$. FT.. U U 0.84 )

\begin{tabular}{|c|c|c|c|c|c|c|}
\hline HEAT ING ENERGY & $S C=0.1$ & $S C=0.2$ & $S C=0.4$ & $S C=0.6$ & $S C=0.8$ & $S C=1.0$ \\
\hline $\begin{array}{l}\text { GAS } \\
\text { OI! }\end{array}$ & $\begin{array}{l}.9 \\
.7\end{array}$ & $\begin{array}{l}.9 \\
.7\end{array}$ & $\begin{array}{l}.7 \\
.6\end{array}$ & $\begin{array}{l}.5 \\
.5\end{array}$ & $\begin{array}{l}.3 \\
.4\end{array}$ & $\begin{array}{l}1 \\
.2\end{array}$ \\
\hline STEAMM & .7 & .7 & .6 & .5 & .4 & .2 \\
\hline
\end{tabular}

20 YEAR PRESENT WORTH FACTOR = 14.3 (GAS), 14.8(OIL), 13.6(STEAM), 12.4(ELEC) MATERIAL \& INSTALLATION COST $=\$ 126000$.

PAY-BACK PERIODS (YEARS) FOR SOLAR SCREENS (COST=\$6.0/SO. FT., U $=0.84$ )

$\begin{array}{ccccccc}\text { HEATING ENERGY } & S C=0.1 & S C=0.2 & S C=0.4 & S C=0.6 & S C=0.8 & S C=1.0 \\ \text { GAS } & >30.0 & >30.0 & >30.0 & >30.0 & >30.0 & >30.0 \\ \text { OIL } & >30.0 & >30.0 & >30.0 & >30.0 & >30.0 & >30.0 \\ \text { STEAM } & >30.0 & >30.0 & >30.0 & >30.0 & >30.0 & >30.0\end{array}$

SAVINGS-TO-INVESTMENT RATIOS FOR SOLAR SCREENS (COST= $\$ 6.0 / 50$. FT., U=0.84)

\begin{tabular}{|c|c|c|c|c|c|c|}
\hline HEATING ENERGY & $S C=0.1$ & $\mathrm{SC}=0.2$ & $S C=0.4$ & $\mathrm{SC}=0.6$ & $S C=0.8$ & $S C=1.0$ \\
\hline $\begin{array}{l}\text { GAS } \\
\text { OIL }\end{array}$ & .5 & $\begin{array}{l}.5 \\
.4\end{array}$ & $\begin{array}{r}.4 \\
.3\end{array}$ & .3 & $\begin{array}{r}.2 \\
.2\end{array}$ & \\
\hline STEAM & .4 & .4 & .3 & .3 & .2 & \\
\hline
\end{tabular}

30 YEAR PRESENT WCRTH FACTOR $=17.3$ (GAS), 21.3 (OIL), 16.2(STEAM). 14.5(ELEC) MATERIAL \& INSTALLATION COST $=\$ 252000$. 
Table 6c. Cost-effectiveness for Phoenix $U=0.50$, Al1-year Cooling

FIRST YEAR ENERGY SAVINGS (DOLLARS) FOR SOLAR SCREENS $(U=\varnothing .5 \varnothing)$

\begin{tabular}{|c|c|c|c|c|c|c|}
\hline 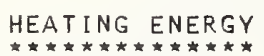 & $S C=\varnothing . I$ & $S C=0.2$ & $S C=\varnothing \cdot 4$ & $\mathrm{SC}=\varnothing .6$ & $\mathrm{SC}=0.8$ & 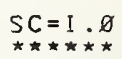 \\
\hline $\begin{array}{l}\text { GAS } \\
\text { OIL } \\
\text { STEAM }\end{array}$ & $\begin{array}{l}19063 . \\
17356 . \\
16645 .\end{array}$ & $\begin{array}{l}17819 . \\
16592 . \\
16081 .\end{array}$ & $\begin{array}{l}15095 . \\
14794 . \\
14668 .\end{array}$ & $\begin{array}{l}\text { I } 0386 . \\
10556 . \\
\text { I } 0627 .\end{array}$ & $\begin{array}{l}5727 . \\
6377 \\
6648 .\end{array}$ & $\begin{array}{l}-36 . \\
1686 . \\
1554 .\end{array}$ \\
\hline
\end{tabular}

ASSUMPTIONS: $\quad$ ELECTRICITY COST $=\$ .062 / \mathrm{KWH}$

HEATING FUEL COST $=\$ . \varnothing 23(\mathrm{GAS}), . \varnothing 38($ IL $), .045(S T E A M) / K W H$

PAY-BACK PERIODS (YEARS) FOR SOLAR SCREENS (COST $=\$ I . \varnothing / S Q . F T ., U=\varnothing .5 \varnothing)$

\begin{tabular}{|c|c|c|c|c|c|c|}
\hline 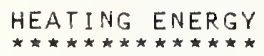 & $\begin{array}{l}S C=\emptyset \cdot I \\
\star \star \star \star \star \star *\end{array}$ & 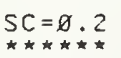 & $\begin{array}{l}S C=\not .4 \\
\star \star \star \star \star \star \star\end{array}$ & $\begin{array}{l}S C=\varnothing, 6 \\
\star \star \star \star \star \star \star * \star *\end{array}$ & $\begin{array}{l}\mathrm{SC}=0.8 \\
\star \star \star \star \star \star \star\end{array}$ & $\begin{array}{l}S C=1 . \varnothing \\
\star \star \star \star \star\end{array}$ \\
\hline $\begin{array}{l}\text { GAS } \\
\text { OIL } \\
\text { STEAM }\end{array}$ & $\begin{array}{l}3.0 \\
3.0 \\
3.8\end{array}$ & $\begin{array}{l}3.0 \\
3.0 \\
3.0\end{array}$ & $\begin{array}{l}3.0 \\
3.0 \\
3.0\end{array}$ & $\begin{array}{l}5.0 \\
5.0 \\
5.0\end{array}$ & $\begin{array}{l}9.0 \\
8.0 \\
7.0\end{array}$ & $\begin{array}{l}>30.0 \\
>30.0 \\
>30.0\end{array}$ \\
\hline
\end{tabular}

SAVINGS-TO-INVESTMENT RATIOS FOR SOLAR SCREENS $(\operatorname{COST}=\$ I . \varnothing / S O . F T . \quad U=\varnothing .5 \varnothing)$

\begin{tabular}{|c|c|c|c|c|c|c|}
\hline HEAT I I G ENERGY & $S C=\varnothing, 1$ & $S C=\varnothing \cdot 2$ & $S C=\varnothing .4$ & $\begin{array}{l}S C=\varnothing .6 \\
x_{* \star *}\end{array}$ & $S C=\varnothing .8$ & $\begin{array}{l}S C=1 . \varnothing \\
\star \star \star \star\end{array}$ \\
\hline $\begin{array}{l}\text { GAS } \\
\text { OIL }\end{array}$ & $\begin{array}{l}3.7 \\
3.4\end{array}$ & $\begin{array}{l}3.5 \\
3.3\end{array}$ & $\begin{array}{l}3.0 \\
2.9\end{array}$ & $\begin{array}{l}2.0 \\
2.1\end{array}$ & $\begin{array}{l}1.1 \\
1.2\end{array}$ & .2 \\
\hline
\end{tabular}

10 YEAR PRESENT WORTH FACTOR $=9.2$ (GAS), 8.0(OIL), 8.7(STEAM), 8.3(ELEC) MATERIAL \& INSTALLATION COST $=\$ 42000$.

PAY-BACK PERIODS (YEARS) FOR SOLAR SCREENS (COST $=\$ 3.0 / 50$. FT., U $=\varnothing .50$ )

\begin{tabular}{|c|c|c|c|c|c|c|}
\hline HEATIIIG ENERGY & $S C=\not 2.1$ & $S C=\varnothing .2$ & $S C=\varnothing .4$ & $S C=\varnothing .6$ & $S C=0.8$ & 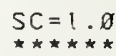 \\
\hline 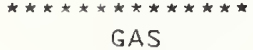 & $\begin{array}{r}* * \star \star \star * \star \\
3 . \emptyset\end{array}$ & $\begin{array}{r}\star * * * * * \\
9 . \varnothing\end{array}$ & $\begin{array}{r}\star \star \star \star \star \star * \star * \\
11 . \varnothing\end{array}$ & $\begin{array}{r}\star \star * \star * \star * * \\
2 \varnothing . \varnothing\end{array}$ & $\begin{aligned} \star \star \star \star \star \star \star \star \\
>3 \varnothing . \varnothing\end{aligned}$ & $\begin{array}{r}\star \star \star \star \star \star \star \\
>3 \varnothing . \varnothing\end{array}$ \\
\hline OIL & $9 . \not$ & 9.0 & 11.0 & I $9 . \varnothing$ & $>3 \varnothing . \varnothing$ & $>3 \varnothing .0$ \\
\hline STEAM & 10.0 & $1 \varnothing . \varnothing$ & 11.0 & I $9 . \varnothing$ & $>3 \varnothing . \varnothing$ & $>3 \varnothing . \varnothing$ \\
\hline
\end{tabular}

SAVINGS-TO-INVESTMENT RATIOS FOR SOLAR SCREENS (COST $=\$ 3.9 / S O . F T ., U=\not .50$ )

\begin{tabular}{|c|c|c|c|c|c|c|}
\hline 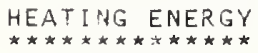 & $\begin{array}{l}S C=D \cdot 1 \\
* * * *\end{array}$ & $\begin{array}{l}S C=\varnothing \cdot 2 \\
S C * * * *\end{array}$ & $\begin{array}{l}S C=g, 4 \\
\star \star \star * *\end{array}$ & $\begin{array}{l}S C=\emptyset .6 \\
* * * * * *\end{array}$ & $\begin{array}{l}S C=\not .8 \\
* * * * * *\end{array}$ & $\begin{array}{l}S C=1 . \varnothing \\
\star \star \star \star * * *\end{array}$ \\
\hline $\begin{array}{l}\text { GAS } \\
\text { OIL } \\
\text { STEAM }\end{array}$ & $\begin{array}{l}\text { I. } 8 \\
1.6 \\
1.6\end{array}$ & $\begin{array}{l}\text { I. } 7 \\
\text { I. } .6 \\
1.5\end{array}$ & $\begin{array}{l}1.5 \\
\text { I. } 4 \\
1.4\end{array}$ & $\begin{array}{l}1.0 \\
1.0 \\
1.0\end{array}$ & $\begin{array}{l}.6 \\
.7 \\
7\end{array}$ & $\begin{array}{l}.0 \\
.2 \\
.2\end{array}$ \\
\hline
\end{tabular}

26 YEAR PRESENT WORTH FACTOR = I 4.3 (GAS), I 4.8 (OIL), 13.6 (STEAM), I 2.4 (ELEC) MATERIAL \& INSTALLATION COST $=\$ 126008$.

PAY-BACK PERIODS (YEARS) FOR SOLAR SCREENS (COST $=\$ 6 . \varnothing / 50 . F T ., U=\varnothing .5 \varnothing$ )

\begin{tabular}{|c|c|c|c|c|c|c|}
\hline 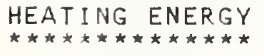 & $\begin{array}{l}S C=\varnothing, 1 \\
\star \star \star \star \star \star\end{array}$ & $\begin{array}{l}S C=\emptyset .2 \\
\star \star \star \star * *\end{array}$ & $\begin{array}{l}S C=\varnothing .4 \\
\star \star \star \star \star \star *\end{array}$ & $\begin{array}{l}S C=\not .6 \\
\star \star \star \star \star \star *\end{array}$ & $\begin{array}{l}S C=\emptyset .8 \\
\star \star \star \star \star \star\end{array}$ & $\begin{array}{l}S C=1.0 \\
\star \star \star \star \star \star \star\end{array}$ \\
\hline $\begin{array}{l}\text { GAS } \\
\text { OIL } \\
\text { STEAM }\end{array}$ & $\begin{array}{r}26 . \varnothing \\
>3 \theta .0 \\
>30.0\end{array}$ & $\begin{array}{r}30.0 \\
>30.0 \\
>30.0\end{array}$ & $\begin{array}{l}>30.0 \\
>30.0 \\
30.0\end{array}$ & $\begin{array}{l}>30 . \varnothing \\
>30.0 \\
>30.0\end{array}$ & $\begin{array}{l}>30.0 \\
>30.0\end{array}$ & $\begin{array}{l}>3 \phi . \varnothing \\
>30.0\end{array}$ \\
\hline
\end{tabular}

SAVINGS-TO-INVESTMENT RATIOS FOR SOLAR SCREENS (COST $=\$ 6 . \varnothing / S O . F T ., U=\varnothing .5 \varnothing)$

\begin{tabular}{|c|c|c|c|c|c|c|}
\hline 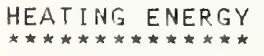 & $\begin{array}{l}S C=\varnothing . I \\
\star \star \star \star \star \star \star\end{array}$ & $\begin{array}{l}S C=\varnothing .2 \\
\star \star \star \star \star \star \star *\end{array}$ & $\begin{array}{l}S C=\varnothing .4 \\
\star \star \star \star *\end{array}$ & $S C=0.6$ & $\begin{array}{l}S C=\emptyset .8 \\
\star \star \star \star * *\end{array}$ & $\begin{array}{l}\mathrm{SC}=\mathrm{I} . \theta \\
\star \star \star \star \star \star\end{array}$ \\
\hline $\begin{array}{l}\text { GAS } \\
\text { OIL } \\
\text { STEAM }\end{array}$ & $\begin{array}{r}1 . I \\
.9 \\
.9\end{array}$ & $\begin{array}{r}\text { I. } \\
.9 \\
.9\end{array}$ & $\begin{array}{l}.9 \\
.8 \\
.8\end{array}$ & $\begin{array}{l}.6 \\
.6 \\
.6\end{array}$ & $\begin{array}{l}.3 \\
.4 \\
.4\end{array}$ & $\begin{array}{l}.0 \\
.1 \\
.1\end{array}$ \\
\hline
\end{tabular}

30 YEAR PRESENT WORTH FACTOR = $17.3(\mathrm{GAS}), 2 \mathrm{I} .3(\mathrm{OIL}), 16.2$ (STEAM), I 4.5 (ELEC) MATERIAL \& INSTALLATION COST $=\$ 252000$. 
Table 6d. Cost-effectiveness for Phoenix U $=0.84$, All-year Cooling FIRST YEAR ENERGY SAVINGS (OOLLARS) FOR SOLAR SCREENS $(U=\varnothing .84)$

\begin{tabular}{|c|c|c|c|c|c|c|}
\hline 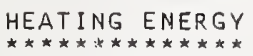 & $\begin{array}{l}S C=\varnothing \cdot 1 \\
* * * * * *\end{array}$ & 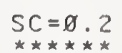 & $\begin{array}{l}S C=\varnothing .4 \\
S C * * * * *\end{array}$ & 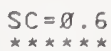 & 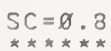 & $\begin{array}{l}S C=1 . \varnothing \\
S * * * * *\end{array}$ \\
\hline $\begin{array}{l}\text { GAS } \\
\text { OIL } \\
\text { STEAM }\end{array}$ & $\begin{array}{l}17128 . \\
14948 \\
14829\end{array}$ & $\begin{array}{l}15949 . \\
14132 . \\
13376\end{array}$ & $\begin{array}{l}13391 . \\
12316 .\end{array}$ & $\begin{array}{l}9289 . \\
8760 . \\
8548\end{array}$ & $\begin{array}{l}5423 . \\
5448 .\end{array}$ & 99. \\
\hline
\end{tabular}

ASSUMPTIONS: $\quad$ ELECTRICITY COST $=\$ .962 / \mathrm{KWH}$

HEATING FUEL COST $=\$ .023\{G A S\}, .038(O I L), .045($ STEAM) $/ K W H$

PAY-BACK PERIODS (YEARS) FOR SOLAR SCREENS (COST $=\$ 1 . \varnothing / S Q$. FT, I $=\varnothing .84$ )

\begin{tabular}{|c|c|c|c|c|c|c|}
\hline 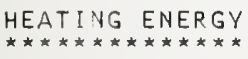 & 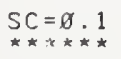 & $\begin{array}{l}S C=\varnothing .2 \\
\star \star \star \star \star \star * \star\end{array}$ & $\begin{array}{l}S C=\not .4 \\
* \star * * *\end{array}$ & $\begin{array}{l}S C=\not .6 \\
* \star \star \star \star \star *\end{array}$ & $\begin{array}{l}S C=\not .8 \\
\star \star \star \star \star \star \star\end{array}$ & $\begin{array}{l}S C=1 . \varnothing \\
\star * \star * * *\end{array}$ \\
\hline $\begin{array}{l}\text { GAS } \\
\text { OIL }\end{array}$ & $\begin{array}{l}3.0 \\
3.0\end{array}$ & $\begin{array}{l}3.0 \\
4.0\end{array}$ & $\begin{array}{l}4.0 \\
4.0\end{array}$ & $\begin{array}{l}5.0 \\
6.8\end{array}$ & $\begin{array}{l}10.0 \\
10.0\end{array}$ & $\begin{array}{l}>30.0 \\
>30.0\end{array}$ \\
\hline STEAM & 4.8 & 4.0 & 4.0 & 6.8 & 10.0 & $>3.0 .0$ \\
\hline
\end{tabular}

SAVINGS-TO-INVESTMENT PATIOS FOR SOLAR SCREENS (COST $=\$ 1 . \varnothing / 50 . \quad F T ., U=\varnothing .84$ )

\begin{tabular}{|c|c|c|c|c|c|c|}
\hline 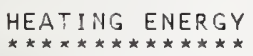 & $\begin{array}{l}S C=\emptyset, 1 \\
\star \star \star \star \star \star \star \star *\end{array}$ & $\begin{array}{l}S C=\varnothing .2 \\
\star * * * * *\end{array}$ & $\begin{array}{l}S C=\varnothing .4 \\
\star \star \star \star \star \star \star\end{array}$ & $\begin{array}{l}\mathrm{SC}=\varnothing .6 \\
\star \star \star \star \star \star \star *\end{array}$ & $\begin{array}{l}S C=\varnothing .8 \\
\star \star \star \star \star \star\end{array}$ & $\begin{array}{l}S C=1 . \varnothing \\
* \star \star * * *\end{array}$ \\
\hline $\begin{array}{l}\text { GAS } \\
\text { OIL }\end{array}$ & $\begin{array}{l}3.3 \\
3.8 \\
2.7\end{array}$ & $\begin{array}{l}3.1 \\
2.8 \\
2.6\end{array}$ & $\begin{array}{l}2.6 \\
2.4 \\
2.3\end{array}$ & $\begin{array}{l}1.8 \\
1.7 \\
1.7\end{array}$ & $\begin{array}{l}1.1 \\
1.1\end{array}$ & $\ldots$ \\
\hline
\end{tabular}

10 VEAR PRESENT WORTH FACTOR $=9.2($ GAS), $8.0(O I L) .8 .7$ (STEAM), 8.3 (ELEC) MATER IAL \& INSTALLATION COST $=\$ 42 \varnothing \varnothing \varnothing$.

PAY-BACK PER.IOOS (YEARS) FOR SOLAR SCREENS (COST $=\$ 3 . \varnothing / 50 . F T, \quad U=\varnothing .84$ )

\begin{tabular}{|c|c|c|c|c|c|c|}
\hline ING ENERGY & $\begin{array}{l}S C=\varnothing, 1 \\
* \star \star * * * *\end{array}$ & $\begin{array}{l}S C=\varnothing .2 \\
* * * * * *\end{array}$ & $\begin{array}{l}S C=\emptyset, 4 \\
* * * * * *\end{array}$ & $\begin{array}{l}S C=\varnothing .6 \\
* * * * *\end{array}$ & $\begin{array}{l}S C=\not 1.8 \\
* * * * * *\end{array}$ & $\begin{array}{l}S C=1 . \varnothing \\
* * * * *\end{array}$ \\
\hline $\begin{array}{l}\text { TAS } \\
\text { OIL }\end{array}$ & $\begin{array}{r}9.0 \\
11.0\end{array}$ & 10.0 & $\begin{array}{l}13.0 \\
15.8 \\
16.0\end{array}$ & $\begin{array}{r}27.0 \\
>30.0 \\
>30.0\end{array}$ & $\begin{array}{l}>30.8 \\
>30.0 \\
30.0\end{array}$ & $\begin{array}{l}>30.0 \\
30.0 \\
30.0\end{array}$ \\
\hline STEAM & 12.0 & 13.8 & $16 . \varnothing$ & $>30 . \varnothing$ & $>3 \theta .0$ & $>30.0$ \\
\hline
\end{tabular}

SAVINGS-TO-INVESTMENT RATIOS FOR SOLAR SCREENS (COST $=\$ 3 . \varnothing / S O . F T . U=\varnothing .84$ )

\begin{tabular}{|c|c|c|c|c|c|c|}
\hline 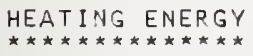 & $\begin{array}{l}S C=\varnothing \cdot 1 \\
\star \star * \star * *\end{array}$ & $\begin{array}{l}\mathrm{SC}=\emptyset .2 \\
\star \star \star \star \star \star \star \star *\end{array}$ & $\begin{array}{l}\mathrm{SC}=\varnothing .4 \\
\star \star * * * \star *\end{array}$ & $\begin{array}{l}S C=0.6 \\
\star \star \star \star \star \star *\end{array}$ & $\begin{array}{l}S C=\theta \cdot 3 \\
\star \star \star \star \star \star \star\end{array}$ & $\begin{array}{l}S C=1 . \varnothing \\
* * * * *\end{array}$ \\
\hline $\begin{array}{l}\text { GAS } \\
\text { OIL }\end{array}$ & $\begin{array}{l}1.6 \\
1.4\end{array}$ & $\begin{array}{l}1.5 \\
1.3\end{array}$ & $\begin{array}{l}1 \cdot 3 \\
1.2\end{array}$ & .9 & $\begin{array}{l}.5 \\
.5\end{array}$ & $---\bar{\sigma}$ \\
\hline STEAM & 1.3 & 1.3 & 1.1 & .8 & .5 & 8 \\
\hline
\end{tabular}

20 YEAR PRESENT WORTH FACTOR $=14.3$ (GAS), $14.8(0 I L), 13.6($ STEAM). 12.4 (ELEC) MATERIAL \& INSTALLATIOY COST = \$126.9日.

PAY-BACK PERIODS (YEARS) FOR SOLAR SCREENS (COST $=\$ 6 . \varnothing / S O$. FT., U $=0.84$ )

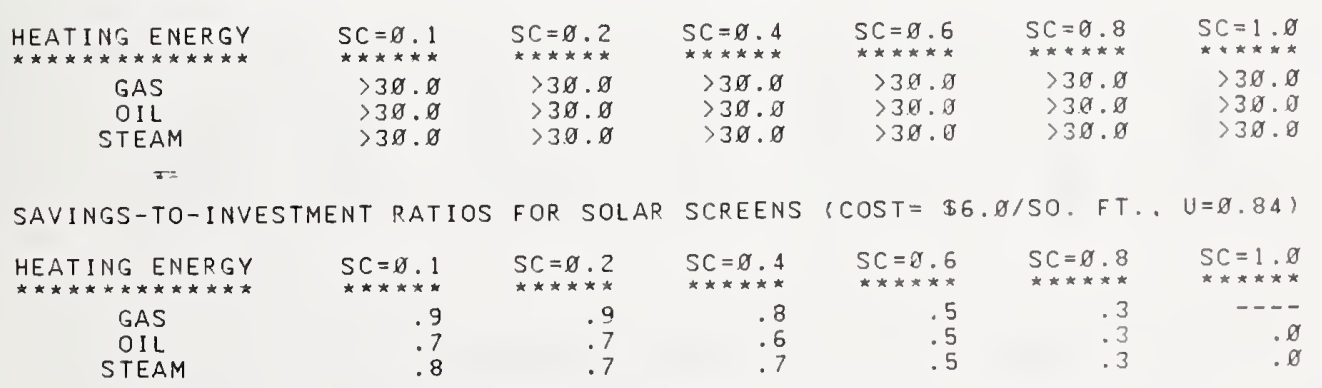

39 YEAR PRESENT WORTH FACTOR $=17.3($ GAS), $21.3(O I L), 16.2($ STEAM), $14.5($ ELEC) MATERIAL \& INSTALLATION COST $=\$ 25200 \emptyset$. 


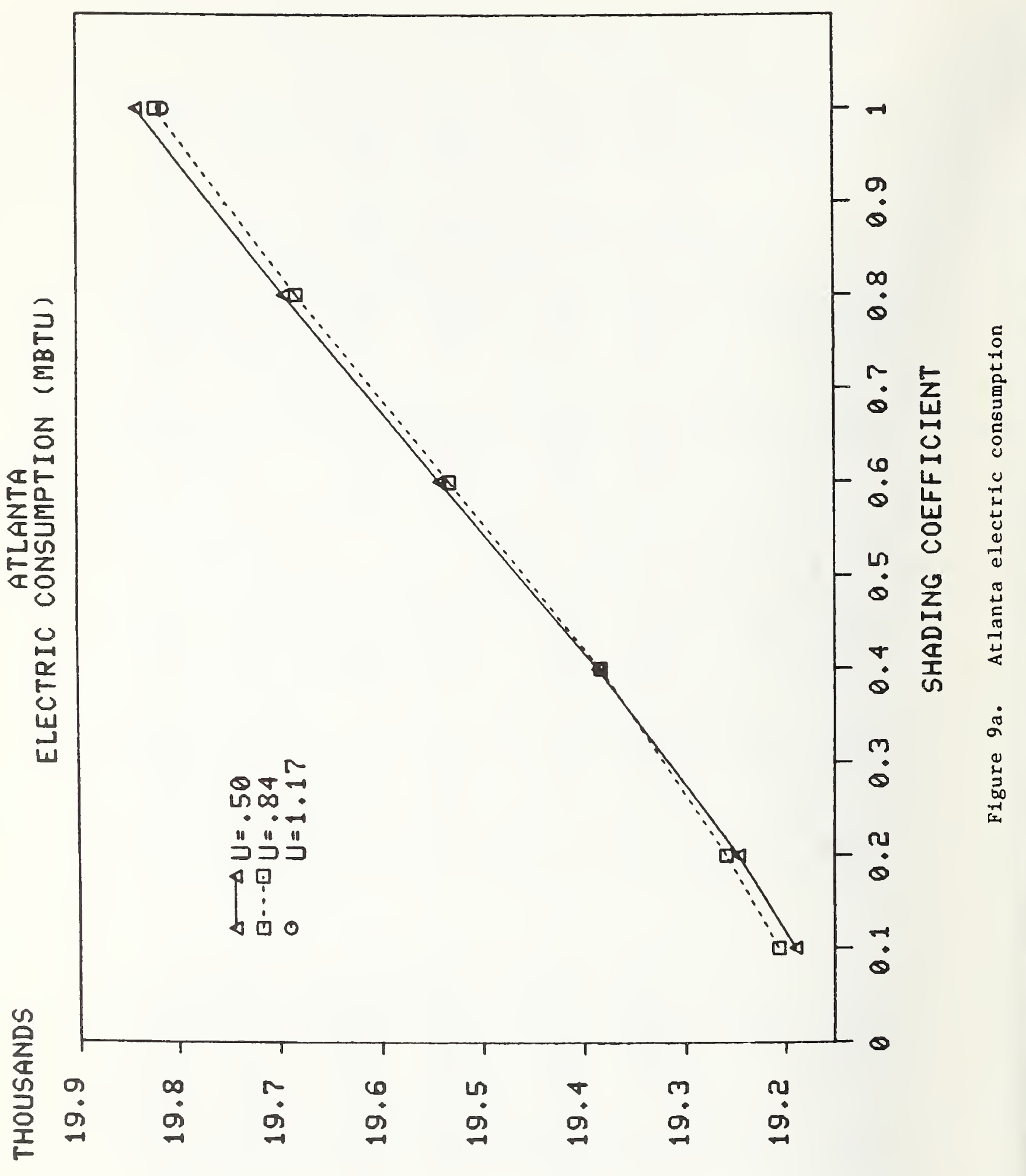

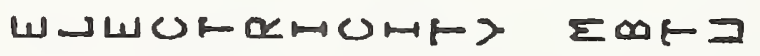




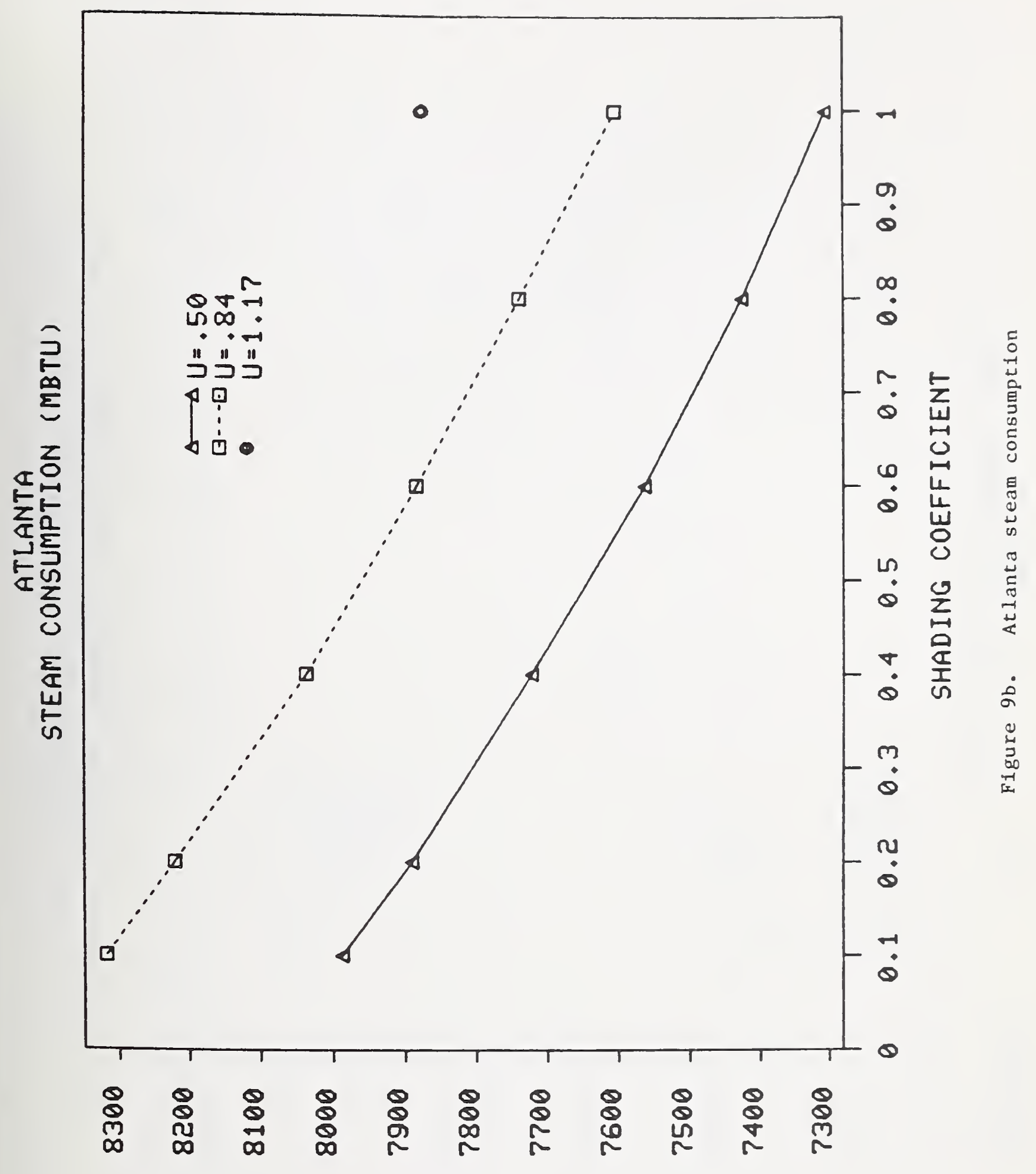

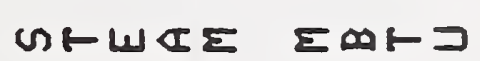




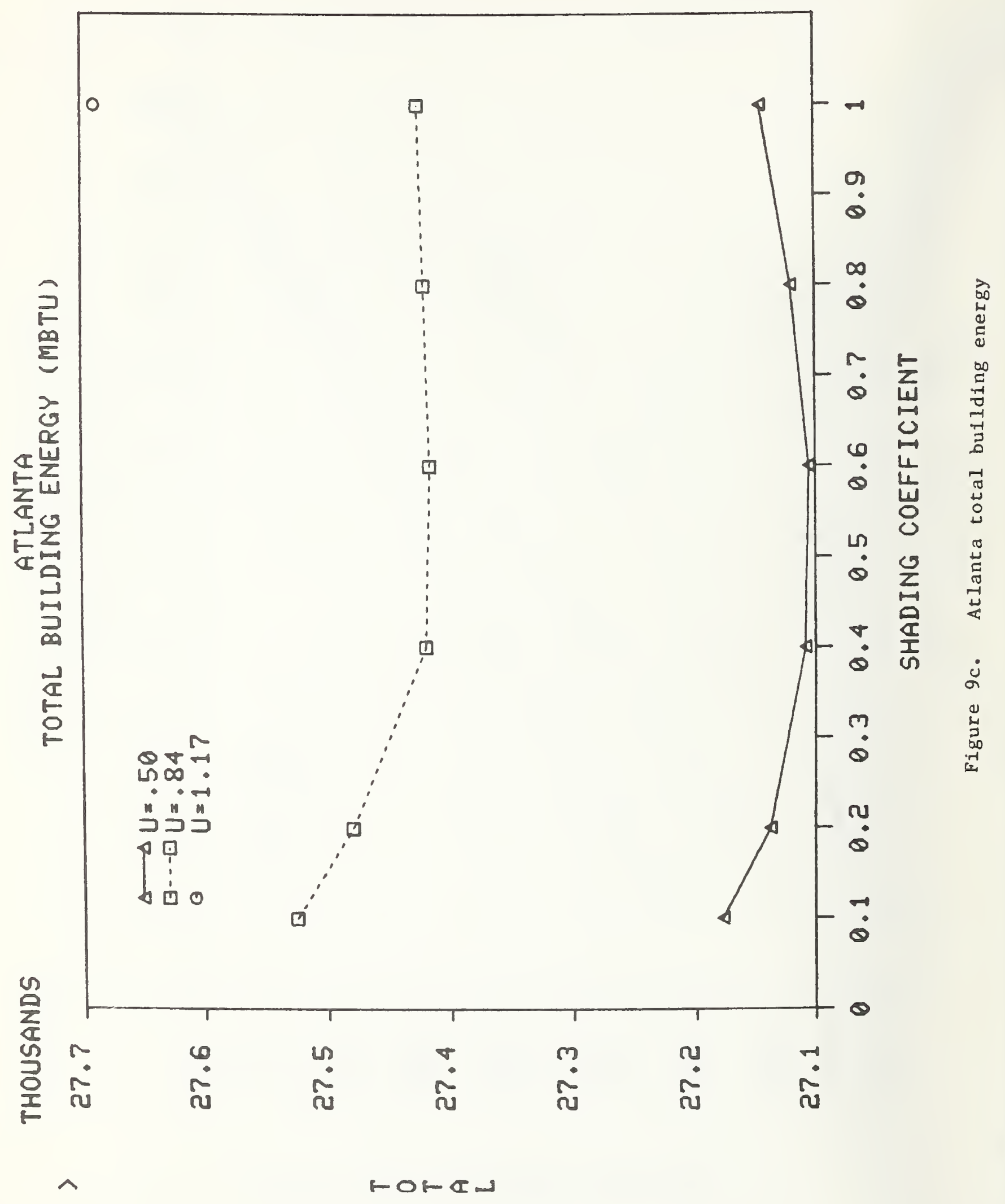




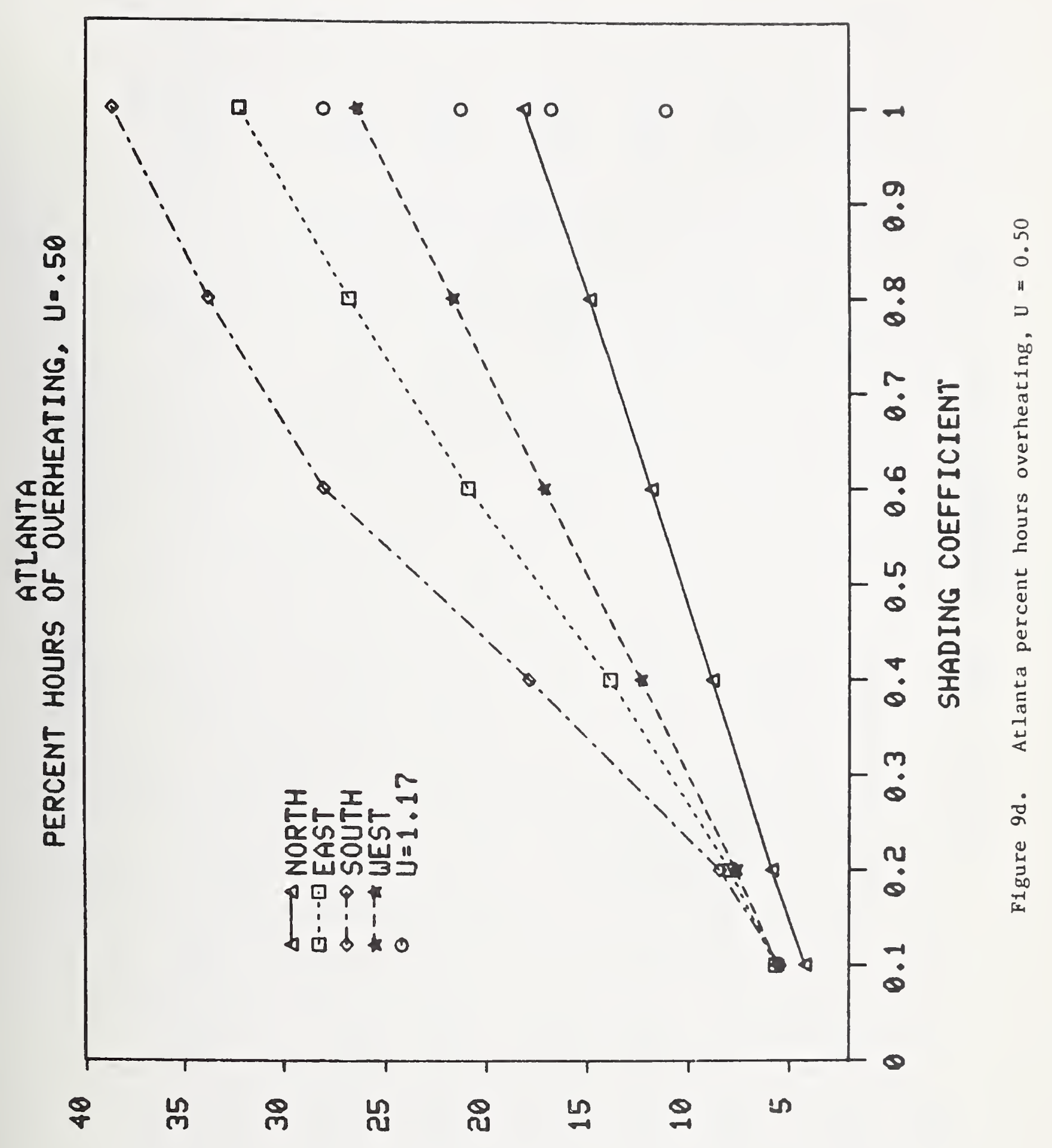

口uवOUZt 


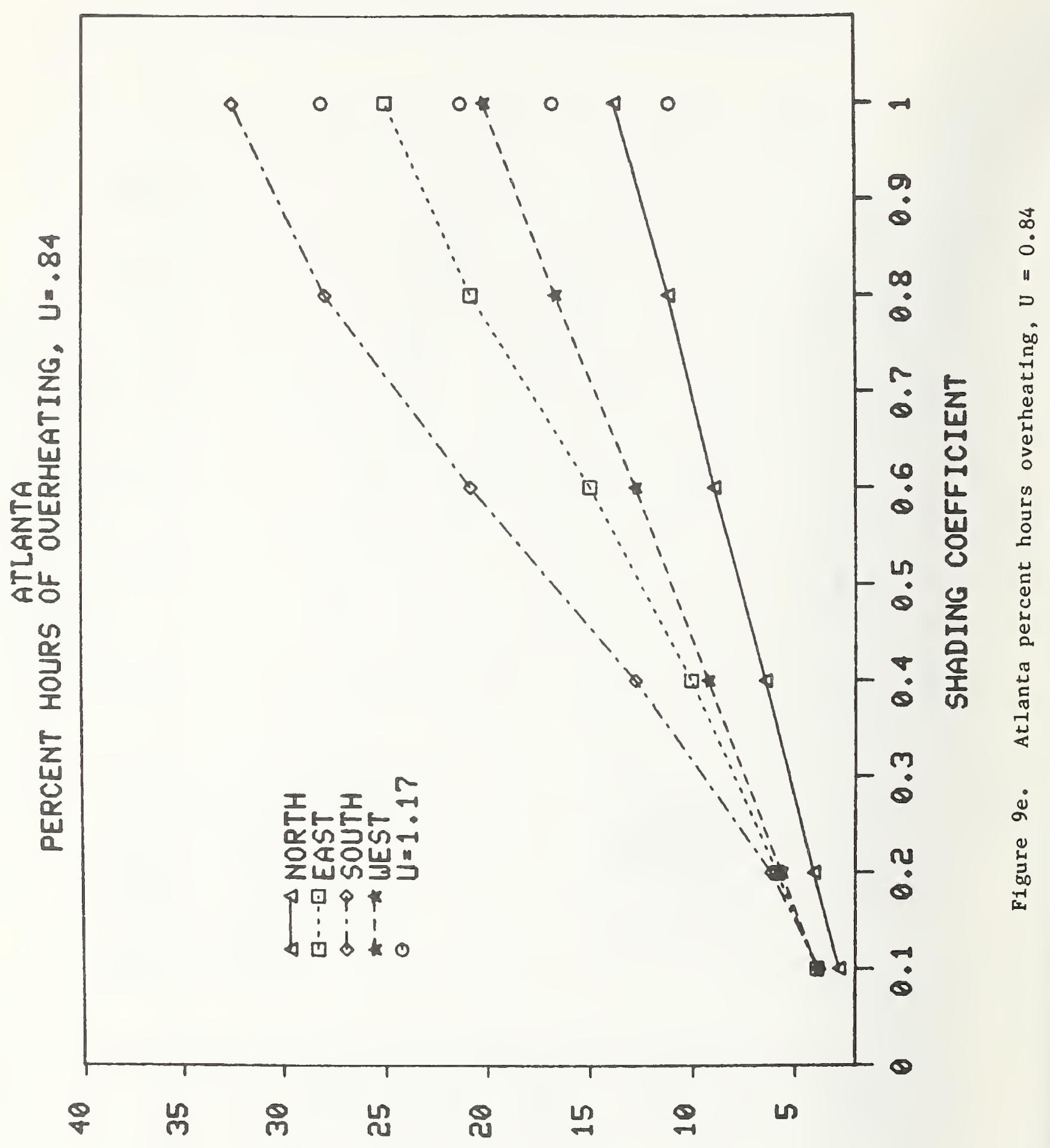

느லWZட 
Table 7a. Cost-effectiveness for Atlanta $U=0.50$, Sumer-only Cooling

FIRST YEAR ENERGY SAVINGS (DOLLARS) FOR SOLAR SCREENS (U=0.50)

$\begin{array}{ccccccc}\text { HEATING ENERGY } & S C=0.1 & \text { SC=0.2 } & \text { SC=0.4 } & \text { SC=0.6 } & S C=0.8 & S C=1.0 \\ \text { GAS } & 8961 . & 8691 . & 7620 . & 6221 . & 4740 . & 3253 . \\ \text { OIL } & 8425 . & 8622 . & 8359 . & 7724 . & 6900 . & 5991 . \\ \text { STEAM } & 8221 . & 8596 . & 8640 . & 8294 . & 7720 . & 7030 .\end{array}$

ASSUMPTIONS: $\quad$ ELECTRICITY COST $=\$ .053 / \mathrm{KWH}$

HEATING FUEL COST $=\$ .022($ GAS). .038(OIL). .045(STEAM)/KWH

PAY-BACK PERIODS (YEARS) FOR SOLAR SCREENS (COST=\$1.0/SO. FT., U:0.50)

\begin{tabular}{crrrrrr} 
HEATING ENERGY & \multicolumn{1}{c}{$S C=0.1$} & SC=0.2 & SC=0.4 & SC=0.6 & SC=0.8 & $S C=1.0$ \\
GAS & 5.0 & 6.0 & 6.0 & 8.0 & 10.0 & 14.0 \\
OIL & 6.0 & 6.0 & 6.0 & 7.0 & 8.0 & 9.0 \\
STEAM & 6.0 & 6.0 & 6.0 & 6.0 & 6.0 & 7.0
\end{tabular}

SAVINGS-TO-INVESTMENT RATIOS FOR SOLAR SCREENS (COST= S1.0/SO. FT., U=O.5O)

$\begin{array}{crrrrrr}\text { HEATING ENERGY } & S C=0.1 & S C=0.2 & S C=0.4 & S C=0.6 & S C=0.8 & S C=1.0 \\ \text { GAS } & 1.8 & 1.8 & 1.6 & 1.3 & 1.1 & 1.8 \\ \text { OIL } & 1.7 & 1.8 & 1.7 & 1.5 & 1.3 & 1.1 \\ \text { STEAM } & 1.7 & 1.7 & 1.8 & 1.7 & 1.6 & 1.5\end{array}$

10 YEAR PRESENT WORTH FACTOR = 10.0(GAS), B.O(OIL), 9.O(STEAM), B.5(ELEC) MATERIAL \& INSTALLATION COST $=\$ 42000$.

PAY-BACK PERIODS (YEARS) FOR SOLAR SCREENS (COST = $\$ 3.0 / 50$. FT.. U=0.50)

$\begin{array}{crrrrrr}\text { HEATING ENERGY } & S C=0.1 & S C=0.2 & S C=0.4 & S C=0.6 & S C=0.8 & S C=1.0 \\ \text { GAS } & 24.0 & 24.0 & 28.0 & >30.0 & >30.0 & >30.0 \\ \text { OIL } & 28.0 & 25.0 & 24.0 & 26.0 & 28.0 & 30.0 \\ \text { STEAM } & 28.0 & 25.0 & 24.0 & 25.0 & 28.0 & >30.0\end{array}$

SAVINGS-TO-INVESTMENT RATIOS FOR SOLAR SCREENS (COST $=\$ 3.0 / S O . F T ., U=0.50$ )

$\begin{array}{crrrrrr}\text { HEATING ENERGY } & S C=0.1 & S C=0.2 & S C=0.4 & S C=0.6 & S C=0.8 & S C=1.0 \\ \text { GAS } & .9 & .9 & .8 & .7 & .6 & .5 \\ \text { OIL } & .9 & .9 & .9 & .9 & .8 & .7 \\ \text { STEAM } & .9 & .9 & .9 & .9 & .9 & .9\end{array}$

20 YEAR PRESENT WORTH FACTOR = 17.5 (GAS). 14.6(OIL). 14.2(STEAM). 13.4(ELEC) MATERIAL \& INSTALLATION COST $=\$ 126000$.

PAY-8ACK PERIODS (YEARS) FOR SOLAR SCREENS (COST = $\$ 6.0 / 50 . F T . . U=0.50$ )

\begin{tabular}{|c|c|c|c|c|c|c|}
\hline HEATING ENERGY & $S C=0.1$ & $S C=0.2$ & $S C=0.4$ & $S C=0.6$ & $S C=0.8$ & $S C=1.0$ \\
\hline $\begin{array}{l}\text { GAS } \\
\text { OIL } \\
\text { STEAM }\end{array}$ & $\begin{array}{l}>30.0 \\
>30.0 \\
>30.0\end{array}$ & $\begin{array}{l}>30.0 \\
>30.0 \\
>30.0\end{array}$ & $\begin{array}{l}>30.0 \\
>30.0 \\
>30.0\end{array}$ & $\begin{array}{l}>30.0 \\
>30.0 \\
>30.0\end{array}$ & $\begin{array}{l}>30.0 \\
>30.0 \\
>30.0\end{array}$ & $\begin{array}{l}>30.0 \\
>30.0 \\
>30.0\end{array}$ \\
\hline
\end{tabular}

SAVINGS-TO-INVESTMENT RATIOS FOR SOLAR SCREENS (COST= \$6.0/SO. FT.. U $=0.50$ )

$\begin{array}{crrrrrr}\text { HEATING ENERGY } & \text { SC=0.1 } & \text { SC=0.2 } & \text { SC=0.4 } & \text { SC=0.6 } & S C=0.8 & S C=1.0 \\ \text { GAS } & .6 & .6 & .5 & .5 & .4 & .3 \\ \text { OIL } & .5 & .6 & .6 & .6 & .5 & .5 \\ \text { STEAM } & .5 & .6 & .6 & .5 & .5\end{array}$

30 YEAR PRESENT WORTH FACTOR = 23.3(GAS).20.8(OIL). 17.1(STEAM). 16.3(ELEC) MATERIAL \& INSTALLATION COST \\$252000. 
Table 7b. Cost-effectiveness for Atlanta $U=0.84$, Summer-only Cooling

FIRST YEAR ENERGY SAVINGS (OOLLARS) FOR SOLAR SCREENS $(U=0.84)$

$\begin{array}{ccccccc}\text { HEATING ENERGY } & \text { SC=0.1 } & \text { SC=0.2 } & \text { SC=0.4 } & \text { SC=0.6 } & \text { SC=0.8 } & S C=1.0 \\ \text { GAS } & 6573 . & 6380 . & 5640 . & 4301 . & 2914 . & 1621 . \\ \text { OIL } & 4451 . & 4728 . & 4870 . & 4265 . & 3570 . & 2924 .\end{array}$

ASSUMPTIONS: $\quad$ ELECTRICITY COST $=\$ .053 / \mathrm{KWH}$

HEATING FUEL COST $=\$ .022$ (GAS),.038(OIL). .045(STEAM)/KWH

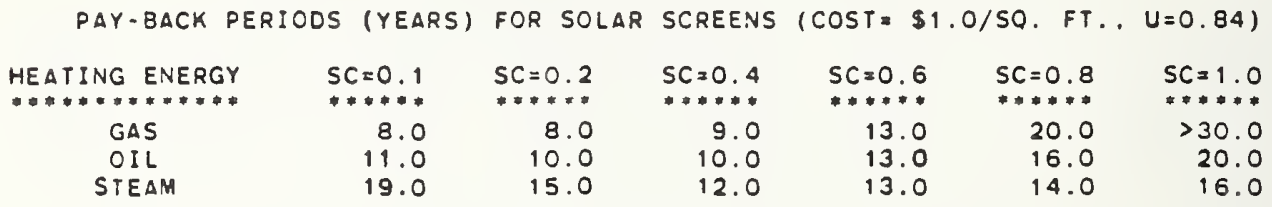

SAVINGS-TO-INVESTMENT RATIOS FOR SOLAR SCREENS (COST $=\$ 1.0 /$ SQ. FT. U U $=0.84$ )

$\begin{array}{crrrrrr}\text { HEATING ENERGY } & S C=0.1 & S C=0.2 & S C=0.4 & S C=0.6 & S C=0.8 & S C=1.0 \\ \text { GAS } & 1.2 & 1.2 & 1.1 & .9 & .6 & .4 \\ \text { OIL } & 1.0 & 1.0 & 1.0 & .9 & .7 & .6 \\ \text { STEAM } & .7 & .8 & .9 & .9 & .8 & .7\end{array}$

10 YEAR PRESENT WORTH FACTOR = 10.0(GAS), 8.O(OIL), 9.0(STEAM), 8.5(ELEC) MATERIAL \& INSTALLATION COST $=\$ 42000$.

PAY-BACK PERICDS (YEARS) FOR SOLAR SCREENS (COST $=\$ 3.0 / S O$. FT. U U $=0.84$ )

$\begin{array}{ccccccc}\text { HEATING ENERGY } & S C=0.1 & S C=0.2 & S C=0.4 & S C=0.6 & S C=0.8 & S C=1.0 \\ \text { GAS } & >30.0 & >30.0 & >30.0 & >30.0 & >30.0 & >30.0 \\ \text { OIL } & >30.0 & >30.0 & >30.0 & >30.0 & >30.0 & >30.0 \\ \text { STEAM } & >30.0 & >30.0 & >30.0 & >30.0 & >30.0 & >30.0\end{array}$

SAVINGS-TO-INVESTMENT RATIOS FOR SOLAR SCREENS (COST=\$3.0/SO. FT . U $=0.84$ )

\begin{tabular}{|c|c|c|c|c|c|c|}
\hline $\begin{array}{l}\text { HEATING ENERGY } \\
\end{array}$ & $S C=0.1$ & $\begin{array}{l}S C=0.2 \\
*\end{array}$ & $S C=0.4$ & $S C=0.6$ & $S C=0.8$ & $S C=1.0$ \\
\hline GAS & .6 & .6 & .6 & .5 & .3 & .2 \\
\hline OIL & .4 & .5 & .5 & .5 & .4 & 3 \\
\hline STEAM & .3 & .4 & .5 & .5 & .4 & 4 \\
\hline
\end{tabular}

20 YEAR PRESENT WORTH FACTOR = 17.5(GAS), 14.6(OIL), 14.2(STEAM), 13.4(ELEC) MATERIAL \& INSTALLATION COST $=\$ 126 C 00$.

PAY-BACK PERIODS (YEARS) FOR SOLAR SCREENS (COST $=\$ 6.0 / S Q$. FT., U=0.84)

$\begin{array}{crrrrrr}\text { HEATING ENERGY } & S C=0.1 & S C=0.2 & S C=0.4 & S C=0.6 & S C=0.8 & S C=1.0 \\ \text { GAS } & >30.0 & >30.0 & >30.0 & >30.0 & >30.0 & >30.0 \\ \text { OIL } & >30.0 & >30.0 & >30.0 & >30.0 & >30.0 & >30.0 \\ \text { STEAM } & >30.0 & >30.0 & >30.0 & >30.0 & >30.0 & >30.0\end{array}$

SAVINGS-TO-INVESTMENT RATIOS FOR SOLAR SCREENS (COST= $\$ 6.0 / S O$. FT. U U $=0.84$ )

$\begin{array}{crrrrrr}\text { HEATING ENERGY } & S C=0.1 & S C=0.2 & S C=0.4 & S C=0.6 & S C=0.8 & S C=1.0 \\ \text { GAS } & .3 & .4 & .3 & .3 & .2 & .2 \\ \text { OIL } & .2 & .2 & .3 & .3 & .3 & .2 \\ \text { STEAM } & .2 & .2 & .3 & .3 & .3 & .3\end{array}$

30 YEAR PRESENT WORTH FACTOR = 23.3(GAS), 20.8(OIL), 17.1(STEAM), 16.3 (ELEC) MATERIAL \& INSTALLATIOIV COST $\equiv \$ 252000$. 
Table $7 \mathrm{c}$. Cost-effectiveness for Atlanta $\mathrm{U}=0.50$, All-year Cooling

FIRST YEAR ENERGY SAVINGS (DOLLARS) FOR SOLAR SCREENS $(U=\varnothing .5 \varnothing)$

\begin{tabular}{|c|c|c|c|c|c|}
\hline 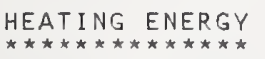 & 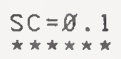 & $\begin{array}{l}S C=\varnothing \cdot 2 \\
\star \star \star * * * *\end{array}$ & $\begin{array}{l}S C=\varnothing \cdot 4 \\
\star \star \star \star \star \star * *\end{array}$ & $\begin{array}{l}S C=\varnothing .6 \\
\star \star \star \star \star \star *\end{array}$ & $\begin{array}{l}S C=\varnothing .8 \\
\star \star \star \star \star \star * *\end{array}$ \\
\hline $\begin{array}{l}\text { GAS } \\
\text { OIL } \\
\text { STEAM }\end{array}$ & $\begin{array}{l}15289 . \\
15203 . \\
15170 .\end{array}$ & $\begin{array}{l}\text { I } 3688 . \\
13913 . \\
1399 .^{\circ} .\end{array}$ & $\begin{array}{l}10345 . \\
11170 . \\
11483 .\end{array}$ & $\begin{array}{l}7252 . \\
8761 . \\
9250 .\end{array}$ & $\begin{array}{l}3986 . \\
6610 . \\
6778 .\end{array}$ \\
\hline
\end{tabular}

ASSUMPTIONS: $\quad$ ELECTRICITY COST $=\$ .053 / \mathrm{KWH}$

HEATING FUEL COST $=\$ . \varnothing 22(\mathrm{GAS}), .038$ (OIL), .Ø45(STEAM) /KWH

PAY-BACK PERIODS (YEARS) FOR SOLAR SCREENS (COST $=\$ 1 . \varnothing / S O$. FT., U $U=\varnothing .5 \varnothing)$

\begin{tabular}{|c|c|c|c|c|c|c|}
\hline 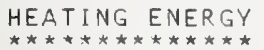 & $\underset{\star \star \star x * \star \star x *}{S C}=\varnothing . I$ & $\begin{array}{l}S C=\varnothing .2 \\
S * * * * *\end{array}$ & $\underset{* \star \star x * * * *}{\mathrm{SC}=\varnothing .4}$ & $\begin{array}{l}\mathrm{SC}=\varnothing .6 \\
\star * * * * *\end{array}$ & $S C=\varnothing .8$ & $S C=1 . \varnothing$ \\
\hline $\begin{array}{l}\text { GAS } \\
\text { OIL } \\
\text { STEAM }\end{array}$ & $\begin{array}{l}3.0 \\
3.0 \\
3 . \varnothing\end{array}$ & $\begin{array}{l}4 . \varnothing \\
4 . \varnothing\end{array}$ & $\begin{array}{l}5.0 \\
4 . \varnothing\end{array}$ & $\begin{array}{l}7.0 \\
6.0 \\
5.0\end{array}$ & $\begin{array}{r}12.0 \\
9.0\end{array}$ & $\begin{array}{r}30.0 \\
19.0\end{array}$ \\
\hline
\end{tabular}

SAVINGS-TO-INVESTMENT RATIOS FOR SOLAR SCREENS (COST $=\$ 1 . \varnothing / S O . \quad F T ., U=\varnothing .5 \varnothing$ )

\begin{tabular}{|c|c|c|c|c|c|c|}
\hline 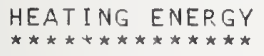 & $\begin{array}{l}S C=\varnothing . I \\
\star \star \star \star \star \star\end{array}$ & $\begin{array}{l}S C=\varnothing .2 \\
\star \star \star \star \star \star \star\end{array}$ & $\begin{array}{l}\mathrm{SC}=\varnothing .4 \\
\star \star \star \star \star \star *\end{array}$ & $\begin{array}{l}S C=\varnothing .6 \\
\star \star \star \star \star \star\end{array}$ & $\begin{array}{l}S C=\varnothing .8 \\
* * * * * *\end{array}$ & $\begin{array}{l}S C=1 . \varnothing \\
* * * * *\end{array}$ \\
\hline $\begin{array}{l}\text { GAS } \\
\text { OIL } \\
\text { STEAM }\end{array}$ & $\begin{array}{l}3.1 \\
3 . I \\
3 . I\end{array}$ & $\begin{array}{l}2.8 \\
2.8 \\
2.8\end{array}$ & $\begin{array}{l}2.1 \\
2.2 \\
2.4\end{array}$ & $\begin{array}{l}1.5 \\
1.7 \\
1.9\end{array}$ & $\begin{array}{r}.9 \\
1.2 \\
1.4\end{array}$ & $\begin{array}{l}.2 \\
.5 \\
.9\end{array}$ \\
\hline
\end{tabular}

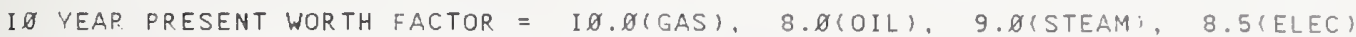
MATERIAL \& INSTALLATION COST $=\$ 42000$.

PAY-BACK PERIODS (YEARS) FOR SOLAR SCREENS (COST $=\$ 3.0 / S O$. FT. I I $=\varnothing .5,5$ )

\begin{tabular}{|c|c|c|c|c|c|c|}
\hline 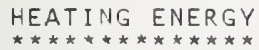 & 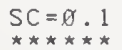 & $\begin{array}{l}S C=\varnothing .2 \\
* * * * * *\end{array}$ & 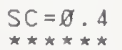 & $\begin{array}{l}\mathrm{SC}=\varnothing .6 \\
* \star \star \star * * *\end{array}$ & $\underset{\star \star \pi * \star \star \pi *}{S C}=\varnothing .8$ & $S C=I, \varnothing$ \\
\hline $\begin{array}{l}\text { GAS } \\
\text { OIL }\end{array}$ & 10.0 & $\begin{array}{l}12 . \varnothing \\
11 . \varnothing\end{array}$ & $\begin{array}{l}17.0 \\
15.0\end{array}$ & 28.0 & $\begin{array}{l}>30 . \varnothing \\
>30 . \theta\end{array}$ & $\begin{array}{r}30.0 \\
30.9\end{array}$ \\
\hline
\end{tabular}

SAVINGS-TO-INVESTMENT RATIOS FOR SOLAR SCREENS (COST $=\$ 3 . \varnothing / S O . F T ., U=\varnothing .50$ )

\begin{tabular}{|c|c|c|c|c|c|c|}
\hline HEATING ENER,GY & $\begin{array}{l}\mathrm{SC}=0.1 \\
\star \star \star \star * \star \star \star *\end{array}$ & $S C=\varnothing .2$ & $\mathrm{SC}=\varnothing .4$ & $S C=\varnothing .6$ & $S C=\not x .8$ & $S C=1 . g$ \\
\hline $\begin{array}{l}\text { GAS } \\
\text { OIL }\end{array}$ & $\begin{array}{l}1.6 \\
1.6\end{array}$ & $\begin{array}{l}1.5 \\
1.5 \\
1.5\end{array}$ & $\begin{array}{l}1.1 \\
1.2 \\
1.2\end{array}$ & $\begin{array}{r}.8 \\
1.0 \\
1.0\end{array}$ & .5 & $\begin{array}{r}.1 \\
.4\end{array}$ \\
\hline
\end{tabular}

20 YEAP PRESENT WORTH FACTOR $=$ I 7.5 (GAS), 14.6 (OIL), 14.2 (STEAM), I 3.4 (ELEC) MATERIAL \& INSTALLATION COST $=\$ 126 \varnothing 00$.

PAY-BACK PERIODS (YEARS) FOR SOLAR SCREENS (COST $=\$ 6.0 / S O$. FT.,U U.

\begin{tabular}{|c|c|c|c|c|c|c|}
\hline 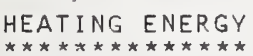 & $\begin{array}{l}S C=\emptyset \cdot 1 \\
S \star \star \star \star \star *\end{array}$ & $\begin{array}{l}S C=\varnothing \cdot 2 \\
x_{\star \star \star \star * \star * *}\end{array}$ & 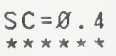 & $\begin{array}{l}S C=\emptyset .6 \\
S * \star \star * \star *\end{array}$ & $\begin{array}{l}S C=\emptyset .8 \\
\star \star \star \star \star \star *\end{array}$ & $\begin{array}{l}S C=1 . \varnothing \\
\star \star * * * *\end{array}$ \\
\hline $\begin{array}{l}\text { GAS } \\
\text { OIL } \\
\text { STEAM }\end{array}$ & $\begin{array}{l}>30 . \varnothing \\
>30 . \varnothing \\
>30 . \varnothing\end{array}$ & $\begin{array}{l}>30.0 \\
>30.0 \\
>30 . \varnothing\end{array}$ & $\begin{array}{l}>30 . \varnothing \\
>3 \varnothing . \varnothing \\
>3 \varnothing . \varnothing\end{array}$ & $\begin{array}{l}>3 \varnothing . \varnothing \\
>30 . \varnothing \\
>3 \varnothing . \varnothing\end{array}$ & $\begin{array}{l}>30 . \varnothing \\
>30 . \varnothing \\
>30 . \varnothing\end{array}$ & $\begin{array}{l}30 . \varnothing \\
30 . \varnothing \\
30 . \varnothing\end{array}$ \\
\hline
\end{tabular}

SAVINGS-TO-INVESTMENT RATIOS FOR SOLAR SCREENS (COST $=\$ 6 . \varnothing / S O . \quad F T, \quad U=\varnothing .50$ )

\begin{tabular}{|c|c|c|c|c|c|c|}
\hline HEAT ING ENERGY & $S C=\not \cdot 1$ & $\begin{array}{l}S C=\varnothing .2 \\
S C=\star * \star *\end{array}$ & $\underset{* x * \star x}{S C}=\varnothing .4$ & 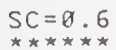 & $\begin{array}{l}S C=0.8 \\
r * * * * *\end{array}$ & $\underset{* * * * *}{S C}=1.0$ \\
\hline $\begin{array}{l}\text { GAS } \\
\text { OIL } \\
\text { STEAM }\end{array}$ & $\begin{array}{l}1 . \varnothing \\
1 . \varnothing \\
1 . \varnothing\end{array}$ & $\begin{array}{l}.9 \\
.9 \\
.9\end{array}$ & $\begin{array}{l}.7 \\
.8 \\
.7\end{array}$ & $\begin{array}{l}.5 \\
.6 \\
.6\end{array}$ & $\begin{array}{r}.3 \\
.5 \\
.5\end{array}$ & $\begin{array}{r}.1 \\
.3 \\
.3\end{array}$ \\
\hline
\end{tabular}

30 YEAR PRESENT WORTH FACTOR $=23.3$ (GAS), 20.8(OIL), 17.1(STEAM), 16.3(ELEC) MATER IAL \& INSTALLATION COST $=\$ 252 \varnothing \varnothing \varnothing$. 
Table 7d. Cost-effectiveness for Atlanta $U=0.84$, All-year Cooling FIRST YEAR ENERGY SAVINGS (DOLLARS) FOR SOLAR SCREENS (U=ø.84)

\begin{tabular}{|c|c|c|c|c|c|c|}
\hline 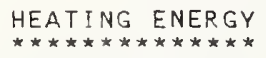 & $\begin{array}{l}\mathrm{SC}=\varnothing .1 \\
\star \star \star \star \star \star \star *\end{array}$ & $\begin{array}{l}\mathrm{SC}=\varnothing .2 \\
\star \star \star \star \star \star \star\end{array}$ & $\begin{array}{l}\mathrm{SC}=\emptyset .4 \\
\star \star \star \star \star \star \star\end{array}$ & $\begin{array}{l}\mathrm{SC}=\varnothing .6 \\
\star \star \star \star \star \star \star *\end{array}$ & $\begin{array}{l}\mathrm{SC}=\varnothing .8 \\
\star \star \star \star \star \star \star\end{array}$ & $\begin{array}{l}S C=1 . \varnothing \\
* * * * * *\end{array}$ \\
\hline $\begin{array}{c}\text { GAS } \\
\text { OIL } \\
\text { STEAM }\end{array}$ & $\begin{array}{l}12793 . \\
11076 . \\
10424 .\end{array}$ & $\begin{array}{r}11534 . \\
10153 . \\
9629 .\end{array}$ & $\begin{array}{l}8846 . \\
8112 . \\
7834 .\end{array}$ & $\begin{array}{l}6159 . \\
6097 . \\
6073 .\end{array}$ & $\begin{array}{l}3487 . \\
4 \varnothing 96 . \\
4327 .\end{array}$ & $\begin{array}{r}675 . \\
1931 . \\
2468 .\end{array}$ \\
\hline
\end{tabular}

ASSUMPTIONS: $\quad$ ELECTR1CITY COST $=\$ .053 / \mathrm{KWH}$

HEATING FUEL COST $=\$ . \varnothing 22$ (GAS), .ø38(OIL), .ø45(STEAM)/KWH

\begin{tabular}{|c|c|c|c|c|c|c|}
\hline$P A Y-B A C K \quad P$ & $S$ SYEARS $)$ & FOR SOLAR & SCREENS & $\cos T=\$$ & Q. F & $U=\varnothing .84)$ \\
\hline 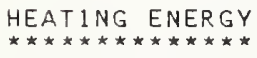 & $\begin{array}{l}\mathrm{SC}=\varnothing \cdot 1 \\
\star * \star \star \star \star *\end{array}$ & $\begin{array}{l}\mathrm{SC}=\varnothing .2 \\
\star \star \star \star \star \star \star\end{array}$ & $\begin{array}{l}\mathrm{SC}=\varnothing .4 \\
\star \star \star \star \star \star \star\end{array}$ & $\begin{array}{l}S C=\not .6 \\
\star \star \star \star \star\end{array}$ & $\begin{array}{l}S C=\not .8 \\
* * * * *\end{array}$ & $\begin{array}{l}\mathrm{SC}=1 . \varnothing \\
\star \star \star \star \star \star \star\end{array}$ \\
\hline $\begin{array}{l}\text { GAS } \\
\text { OIL } \\
\text { STEAM }\end{array}$ & $\begin{array}{l}4 . \varnothing \\
4 . \varnothing \\
5 . \varnothing\end{array}$ & $\begin{array}{l}4.0 \\
5.0 \\
5.0\end{array}$ & $\begin{array}{l}6.0 \\
6.0 \\
6.0\end{array}$ & $\begin{array}{l}3.0 \\
8 . \varnothing \\
8 . \varnothing\end{array}$ & $\begin{array}{l}16 . \varnothing \\
14.0 \\
12 . \varnothing\end{array}$ & $\begin{array}{r}>3 \varnothing . \varnothing \\
29 . \varnothing \\
3 \varnothing . \varnothing\end{array}$ \\
\hline
\end{tabular}

SAVINGS-TO-1NVESTMENT RATIOS FOR SOLAR SCREENS (COST $=\$ 1 . \varnothing / S O . F T . . U=\not .84$ )

\begin{tabular}{|c|c|c|c|c|c|c|}
\hline 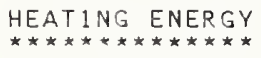 & $\begin{array}{l}\mathrm{SC}=0 \cdot 1 \\
\star \star \star \star \star \star \star *\end{array}$ & $\begin{array}{l}\mathrm{SC}=\varnothing .2 \\
\star \star \star \star \star \star\end{array}$ & $\begin{array}{l}\mathrm{SC}=\varnothing \cdot 4 \\
\star \star \star \star \star \star \star\end{array}$ & $\begin{array}{l}\mathrm{SC}=\varnothing .6 \\
\star \star \star \star \star \star\end{array}$ & $\begin{array}{l}S C=\emptyset .8 \\
\star \star \star \star \star \star\end{array}$ & $\begin{array}{l}\mathrm{SC}=1 . \emptyset \\
\star \star \star \star \star \star\end{array}$ \\
\hline $\begin{array}{l}\text { GAS } \\
\text { OIL } \\
\text { STEAM }\end{array}$ & $\begin{array}{l}2.5 \\
2.3 \\
2.1\end{array}$ & $\begin{array}{l}2.3 \\
2.1 \\
1.9\end{array}$ & $\begin{array}{l}1.8 \\
1.7 \\
1.6\end{array}$ & $\begin{array}{l}1.2 \\
1.2 \\
1.2\end{array}$ & $\begin{array}{l}.7 \\
.8 \\
.9\end{array}$ & \\
\hline
\end{tabular}

10 YEAR PRESENT WORTH FACTOR = 10.0 (GAS), 8. (OLL). 9.0(STEAM), 8.5(ELEC) MATERIAL \& INSTALLATION COST = \$42ØØØ.

PAY-BACK PERIODS (YEARS) FOR SOLAR SCREENS (COST $=\$ 3 . \varnothing / S O . F T ., 1 \mathrm{~J}=\not 2.84$ )

\begin{tabular}{|c|c|c|c|c|c|c|}
\hline 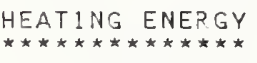 & $\begin{array}{l}\mathrm{SC}=\varnothing \cdot 1 \\
\star \star \star \star \star \star \star\end{array}$ & 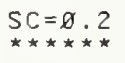 & $\begin{array}{l}\mathrm{SC}=\varnothing .4 \\
\star \star \star \star \star \star\end{array}$ & $\begin{array}{l}\mathrm{SC}=\varnothing .6 \\
\star \star \star \star \star \star\end{array}$ & $\begin{array}{l}\mathrm{SC}=\partial .8 \\
\star \star \star \star \star \star\end{array}$ & $\begin{array}{l}\mathrm{SC}=1 . \varnothing \\
\star \star \star \star \star \star\end{array}$ \\
\hline $\begin{array}{l}\text { GAS } \\
\text { OIL } \\
\text { STEAM }\end{array}$ & $\begin{array}{l}13 . \varnothing \\
16 . \varnothing \\
18 . \varnothing\end{array}$ & $\begin{array}{l}16.0 \\
18 . \varnothing \\
21 . \varnothing\end{array}$ & $\begin{aligned} & 25 . \varnothing \\
> & 30.0 \\
> & 30 . \varnothing\end{aligned}$ & $\begin{array}{l}>3 x \cdot \theta \\
>3 x \cdot x \\
>3 \theta . \theta\end{array}$ & $\begin{array}{l}>30 . \varnothing \\
>30.0 \\
>30 . \varnothing\end{array}$ & $\begin{array}{l}>3 \theta .0 \\
>30 . \varnothing \\
>30 . \varnothing\end{array}$ \\
\hline
\end{tabular}

SAVIHGS-TO-1NVESTMENT RATIOS FOR SOLAR SCREENS (COST= $\$ 3 . \varnothing / S O . F T ., U=\varnothing .84$ )

\begin{tabular}{|c|c|c|c|c|c|c|}
\hline 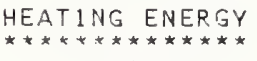 & $\begin{array}{l}S C=\varnothing \cdot 1 \\
\star \star \star \star \star \star \star\end{array}$ & $\begin{array}{l}S C=\varnothing .2 \\
\star \star \star \star \star \star \star\end{array}$ & $\begin{array}{l}S C=\varnothing .4 \\
\star \star \star \star \star \star\end{array}$ & $\begin{array}{l}\mathrm{SC}=\varnothing .6 \\
\star \star \star \star \star \star \star \star\end{array}$ & $\begin{array}{l}\mathrm{SC}=\emptyset .8 \\
\star \star \star \star \star \star \star\end{array}$ & $\begin{array}{l}\mathrm{SC}=1 . \emptyset \\
\star \star \star \star \star \star \star\end{array}$ \\
\hline $\begin{array}{l}\text { GAS } \\
\text { O1L } \\
\text { STEAM }\end{array}$ & $\begin{array}{l}1.3 \\
1.1 \\
1.1\end{array}$ & $\begin{array}{l}1.2 \\
1.0 \\
1.0\end{array}$ & $\begin{array}{l}.9 \\
.8 \\
.8\end{array}$ & $\begin{array}{l}.7 \\
.6 \\
.6\end{array}$ & $\begin{array}{l}.4 \\
.4 \\
.5\end{array}$ & \\
\hline
\end{tabular}

26 YEAP PRESENT WORTH FACTOR = $17.5($ GAS $) .14 .6(011): 14.2(S T E A M) .13 .4(E L E C)$ MATERIAL \& INSTALLATION COST = \$12689ø.

PAY-BACK PER $10 D S$ (YEARS) FOR SOLAR SCREENS (COST $=\$ 6 . \varnothing / S Q . F T ., U=\varnothing .84$ )

\begin{tabular}{|c|c|c|c|c|c|c|}
\hline 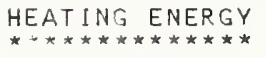 & $\begin{array}{l}\mathrm{SC}=\varnothing \cdot 1 \\
\star \star \star \star \star \star \star\end{array}$ & $\begin{array}{l}\mathrm{SC}=\emptyset \cdot 2 \\
\star \star \star \star * \star *\end{array}$ & $\begin{array}{l}\mathrm{SC}=\varnothing \cdot 4 \\
\star \star \star \star \star \star\end{array}$ & $\begin{array}{l}\mathrm{SC}=\varnothing .6 \\
\star \star \star \star \star \star\end{array}$ & $\begin{array}{l}\mathrm{SC}=\varnothing .8 \\
\star \star \star \star \star \star\end{array}$ & $\begin{array}{l}S C=1 . \varnothing \\
\star \star \star \star \star \star \star\end{array}$ \\
\hline $\begin{array}{c}\text { GAS } \\
\text { OIL } \\
\text { STEAIY }\end{array}$ & $\begin{array}{l}>3 \varnothing \cdot \theta \\
>3 \theta \cdot \theta \\
>3 \varnothing \cdot \theta\end{array}$ & $\begin{array}{l}>30 \cdot 0 \\
>30 \cdot 0 \\
>30 \cdot 0\end{array}$ & $\begin{array}{l}>3 \theta \cdot \theta \\
>30 \cdot \theta \\
>30 \cdot \theta\end{array}$ & $\begin{array}{l}>3 \theta \cdot \theta \\
>30 \cdot \theta \\
>30 \cdot \theta\end{array}$ & $\begin{array}{l}>30.0 \\
>30.0 \\
>30.0\end{array}$ & $\begin{array}{l}>30 \cdot 0 \\
>30 \cdot \theta \\
>30 \cdot \theta\end{array}$ \\
\hline
\end{tabular}

SAV1NGS-TO-INVESTMENT RATIOS FOR SOLAR SCREENS (COST $=\$ 6 . \varnothing / S O . F T ., U=\varnothing .84$ )

\begin{tabular}{|c|c|c|c|c|c|c|}
\hline 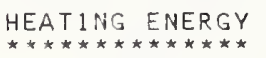 & $\begin{array}{l}\mathrm{SC}=\varnothing \cdot 1 \\
\star \star \star \star \star \star *\end{array}$ & $\begin{array}{l}S C=\varnothing .2 \\
S_{\star \star \star * * *}\end{array}$ & $\begin{array}{l}\mathrm{SC}=\varnothing .4 \\
\star \star \star \star \star \star \star\end{array}$ & $\begin{array}{l}\mathrm{SC}=\varnothing .6 \\
\star \star \star \star \star \star\end{array}$ & $\begin{array}{l}\mathrm{SC}=\not 1.8 \\
\star \star \star \star \star \star\end{array}$ & $\begin{array}{l}\mathrm{SC}=1 . \varnothing \\
\star \star \star \star \star \star\end{array}$ \\
\hline $\begin{array}{l}\text { GAS } \\
\text { O1L } \\
\text { STEAM }\end{array}$ & $\begin{array}{l}.8 \\
.5 \\
.7\end{array}$ & $\begin{array}{l}.7 \\
.6 \\
.6\end{array}$ & $\begin{array}{l}.5 \\
.5 \\
.5\end{array}$ & $\begin{array}{l}.4 \\
.4 \\
.4\end{array}$ & $\begin{array}{l}.2 \\
.3 \\
.3\end{array}$ & $\begin{array}{l}.1 \\
.2 \\
.2\end{array}$ \\
\hline
\end{tabular}

39 YEAR PRESENT WORTH FACTOR $=23.3$ (GAS), 20.8(O1L). 17.1(STEAM). 16.3(ELEC) MATEPIAL \& INSTALLAT1ON COST = \$252Øø. 


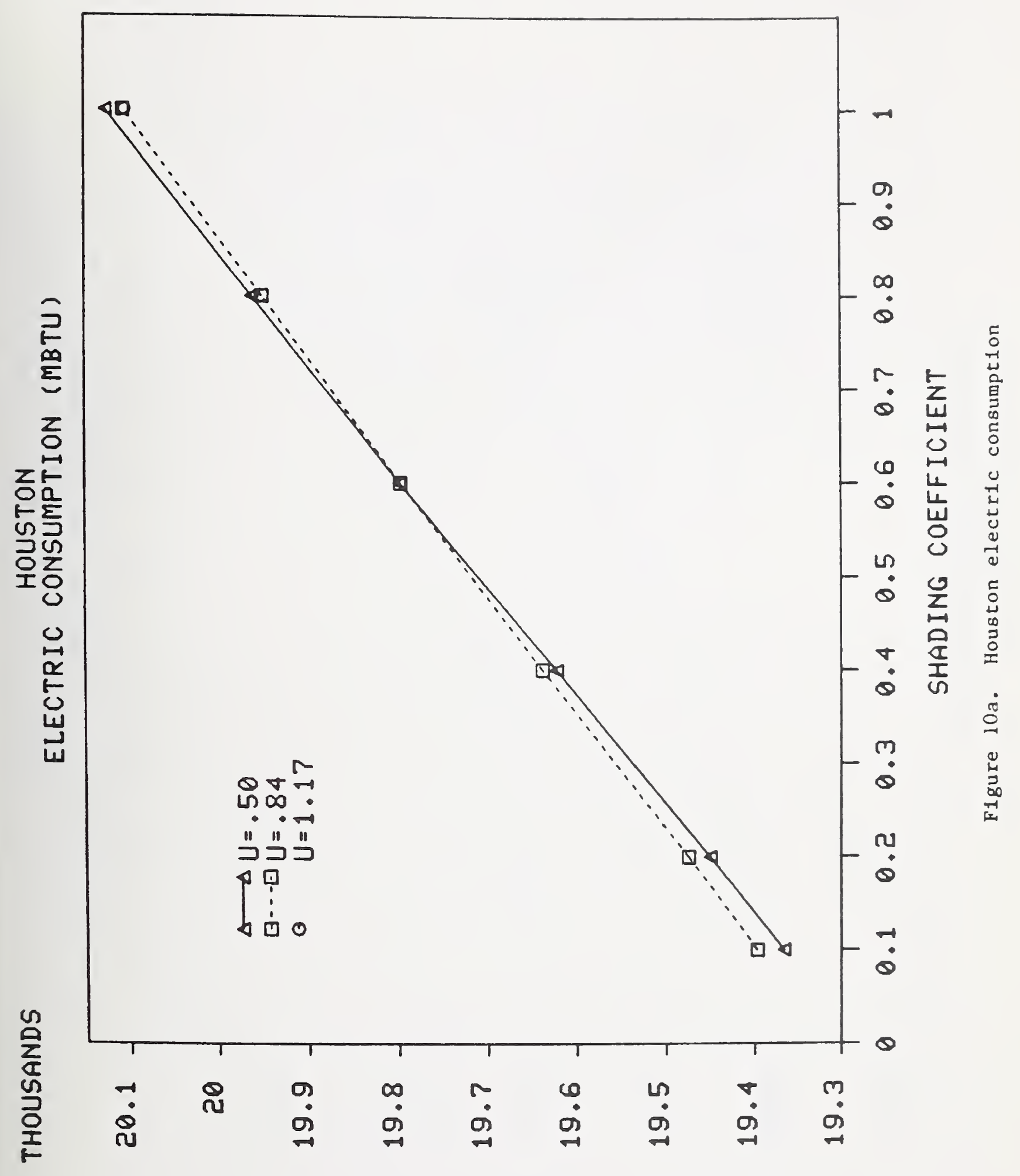

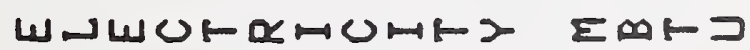




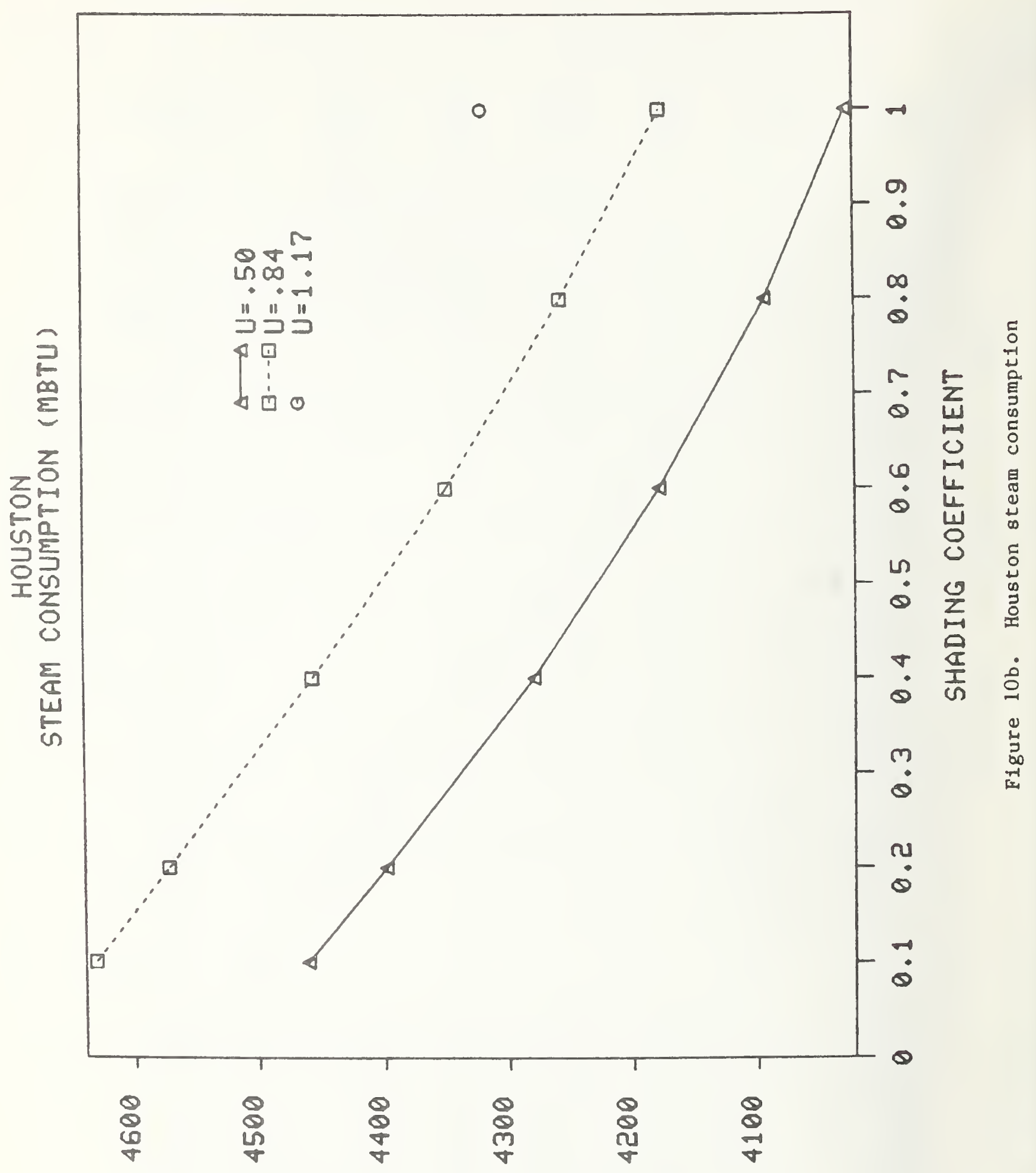

NFWIE 


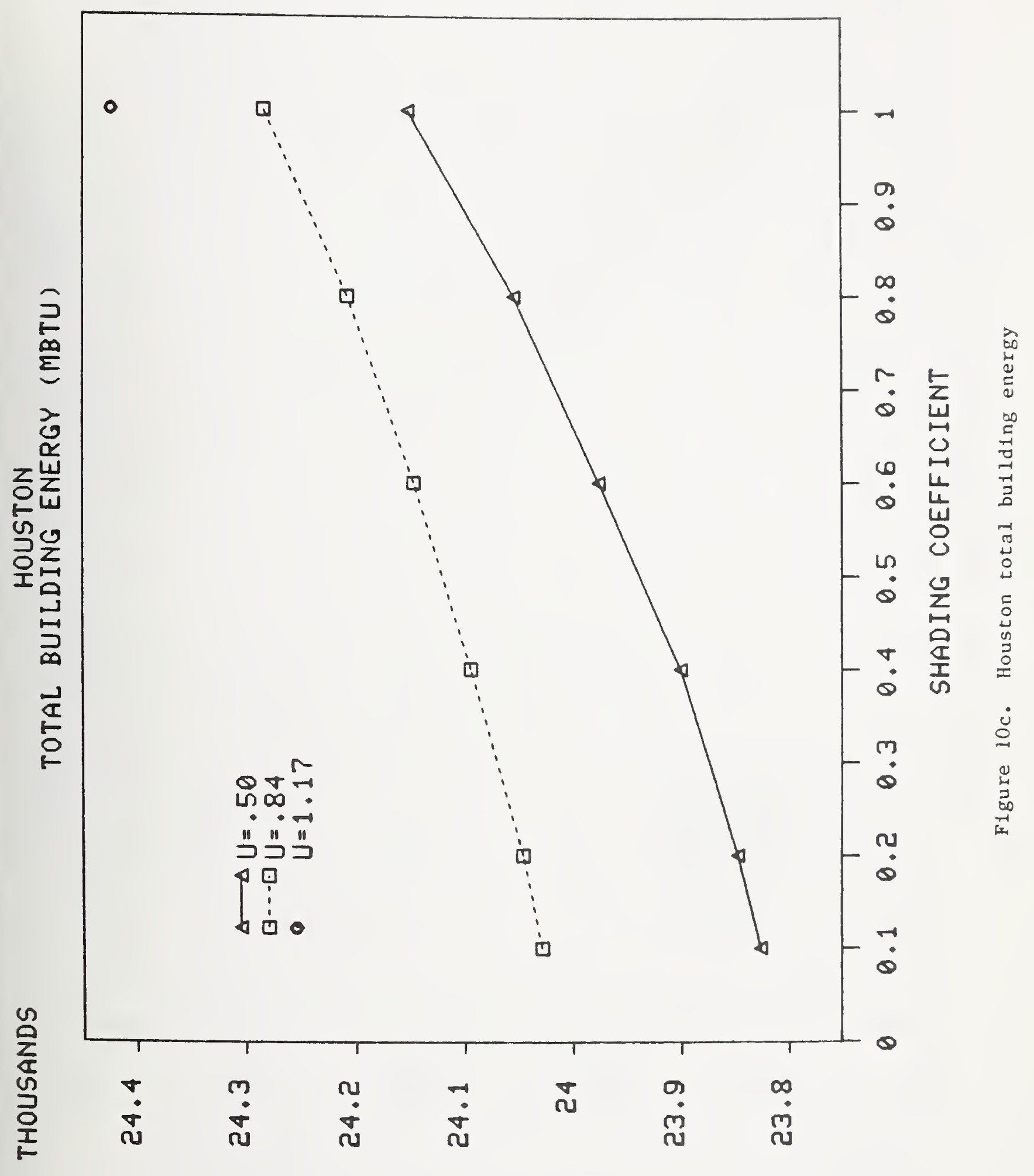

tot 


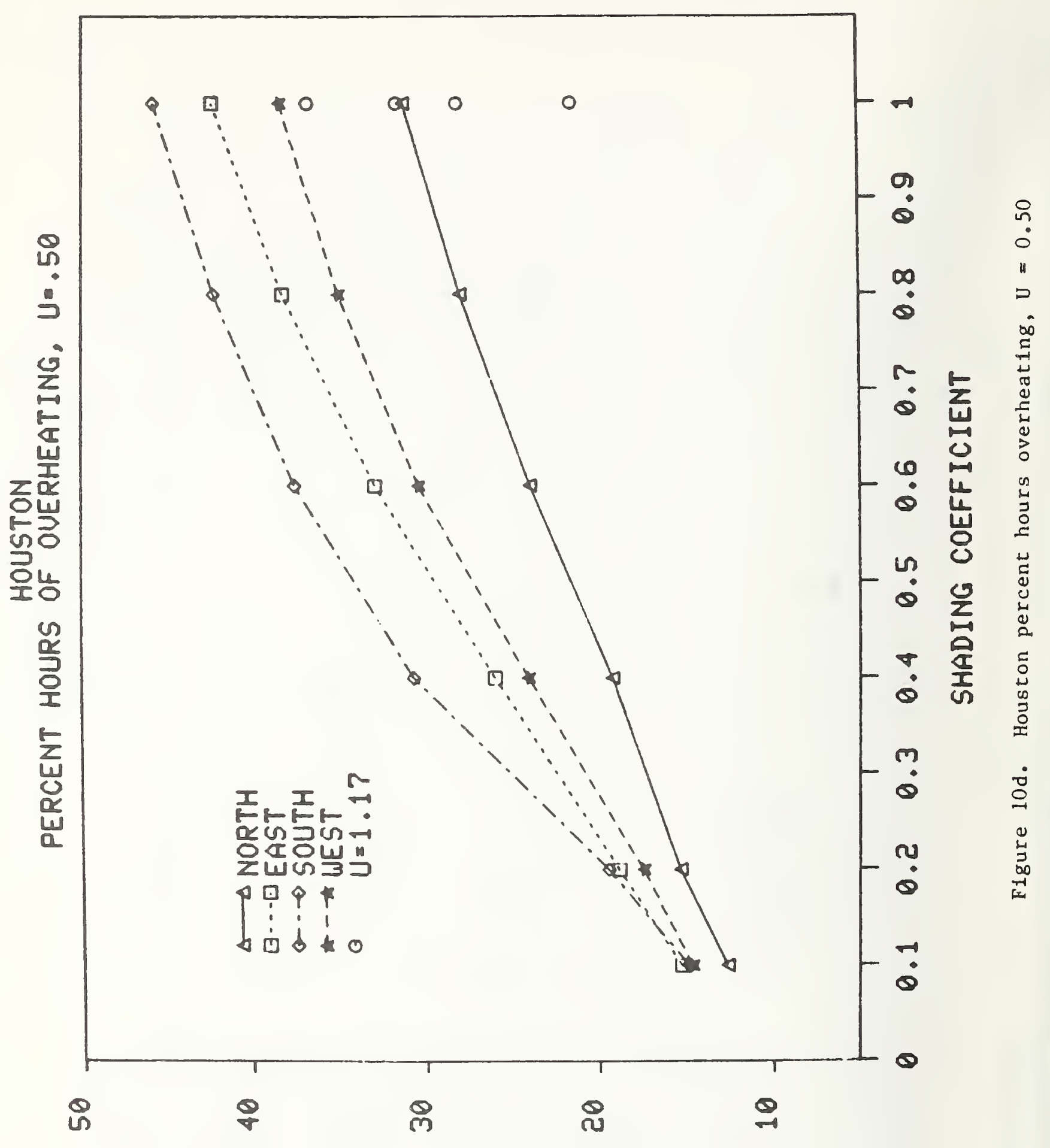

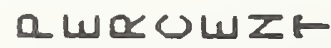




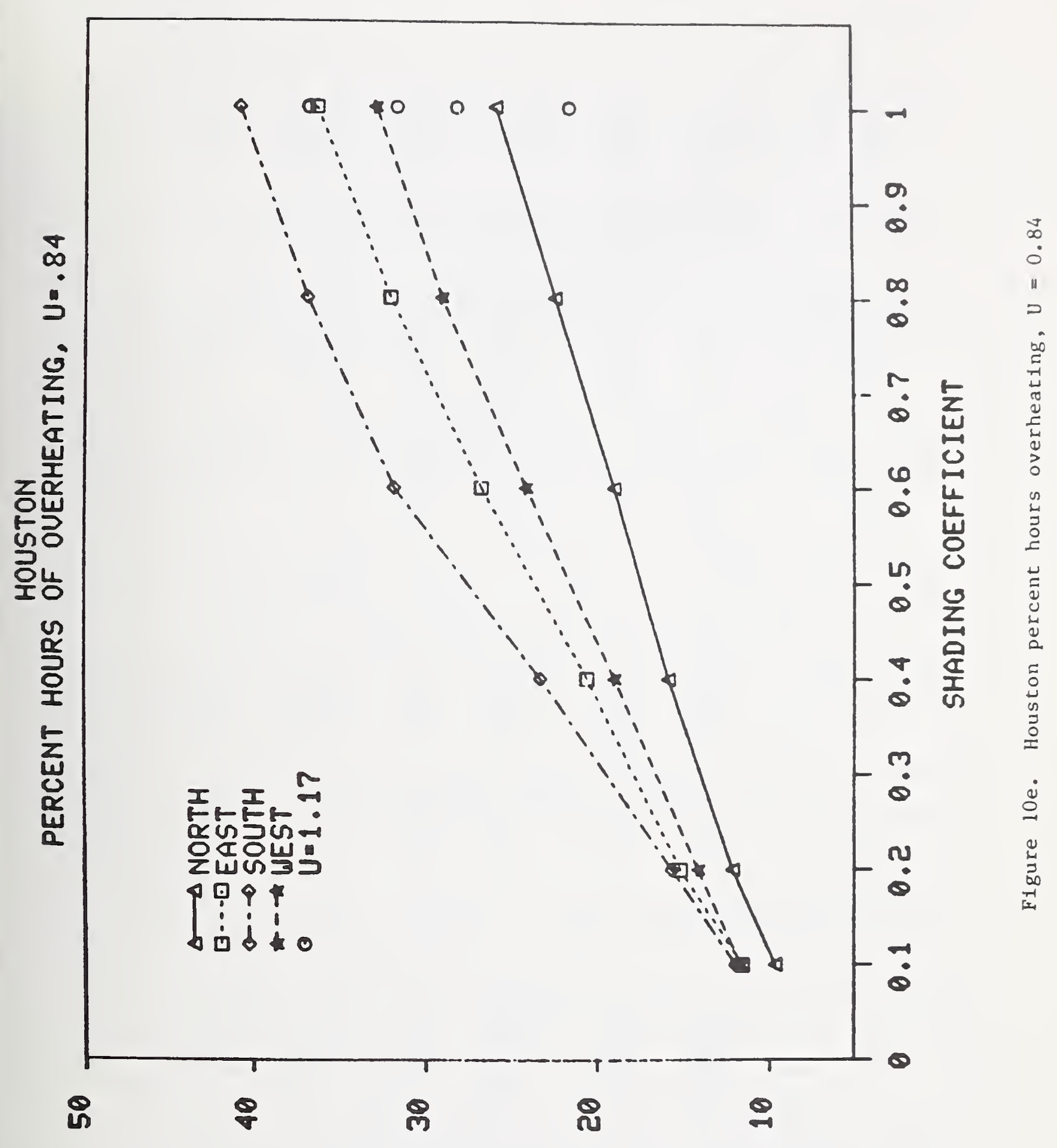

ดயoงแzட 
Table 8a. Cost-effectiveness for Houston $U=0.50$, Summer-only Cooling

FIRST YEAR ENERGY SAVINGS (DOLLARS) FOR SOLAR SCREENS $(U=0.50)$

$\begin{array}{ccccccr}\text { HEATING ENERGY } & S C=0.1 & \text { SC=0.2 } & \text { SC=0.4 } & S C=0.6 & S C=0.8 & S C=1.0 \\ \text { GAS } & 10187 . & 9234 . & 7246 . & 5116 . & 3102 . & 990 . \\ \text { OIL } & 9227 . & 8700 . & 7519 . & 6076 . & 4641 . & 2986 . \\ \text { STEAM } & 8970 . & 8557 . & 7593 . & 6333 . & 5053 . & 3520 .\end{array}$

ASSUMPTIONS: ELECTRICITY COST $=\$ .050 / \mathrm{KWH}$

HEATING FUEL COST $=$ S.015(GAS), .038(OIL), .045(STEAM)/KWH

PAY-BACK PERIOOS (YEARS) FOR SOLAR SCREENS (COST $=\$ 1.0 / S O$. FT. U U $=0.50$ )

$\begin{array}{crrrrrr}\text { HEATING ENERGY } & S C=0.1 & \mathrm{SC}=0.2 & \mathrm{SC}=0.4 & \mathrm{SC}=0.6 & \mathrm{SC}=0.8 & S C=1.0 \\ \text { GAS } & 5.0 & 5.0 & 7.0 & 10.0 & 20.0 & >30.0 \\ \text { OIL } & 5.0 & 6.0 & 7.0 & 8.0 & 12.0 & 19.0 \\ \text { STEAM } & 5.0 & 6.0 & 6.0 & 8.0 & 10.0 & 16.0\end{array}$

SAVINGS-TO-INVESTMENT RATIOS FOR SOLAR SCREENS (COST $\$ \$ 1.0 / 50$. FT., $U=0.50$ )

$\begin{array}{crrrrrr}\text { HEATING ENERGY } & S C=0.1 & S C=0.2 & S C=0.4 & S C=0.6 & S C=0.8 & S C=1.0 \\ \text { GAS } & 2.0 & 1.8 & 1.4 & 1.0 & .6 & .2 \\ \text { OIL } & 1.8 & 1.7 & 1.5 & 1.2 & .9 & .6 \\ \text { STEAM } & 1.8 & 1.7 & 1.5 & 1.3 & 1.0 & .7\end{array}$

10 YEAR PRESENT WORTH FACTOR = 9.3(GAS). 8.O(OIL), 8.8(STEAM). 8.3(ELEC) MATERIAL \& INSTALLATION COST $=\$ 42000$.

PAY-BACK PERIODS (YEARS) FOR SOLAR SCREENS (COST $=\$ 3.0 / 50$. FT. $U=0.50$ )

$\begin{array}{ccccccc}\text { HEATING ENERGY } & S C=0.1 & S C=0.2 & S C=0.4 & S C=0.6 & S C=0.8 & S C=1.0 \\ \text { GAS } & 19.0 & 23.0 & >30.0 & >30.0 & >30.0 & >30.0 \\ \text { OIL } & 25.0 & 28.0 & >30.0 & >30.0 & >30.0 & >30.0 \\ \text { STEAM } & 26.0 & 28.0 & >30.0 & >30.0 & >30.0 & >30.0\end{array}$

SAVINGS-TO-INVESTMENT RATIOS FOR SOLAR SCREENS (COST $=\$ 3.0 /$ SO. FT., $U=0.50$ )

$\begin{array}{crrrrrr}\text { HEATING ENERGY } & S C=0.1 & S C=0.2 & S C=0.4 & S C=0.6 & S C=0.8 & S C=1.0 \\ \text { GAS } & 1.0 & .9 & .7 & .5 & .3 & .1 \\ \text { OIL } & .9 & .9 & .8 & .6 & .5 & .4 \\ \text { STEAM } & .9 & .9 & .8 & .7 & .5 & .4\end{array}$

20 YEAR PRESENT WCRTH FACTOR $=15.2$ (GAS), 14.6(OIL), 14.1(STEAM), 12.9(ELEC) MATERIAL \& INSTALLATION COST $=\$ 126000$.

PAY-BACK PERIOOS (YEARS) FOR SOLAR SCREENS (COST=\$6.0/SO. FT . U U $=0.50$ )

$\begin{array}{ccccccc}\text { HEATING ENERGY } & S C=0.1 & S C=0.2 & S C=0.4 & S C=0.6 & S C=0.8 & S C=1.0 \\ \text { GAS } & >30.0 & >30.0 & >30.0 & >30.0 & >30.0 & >30.0 \\ \text { OIL } & >30.0 & >30.0 & >30.0 & >30.0 & >30.0 & >30.0 \\ \text { STEAM } & >30.0 & >30.0 & >30.0 & >30.0 & >30.0 & >30.0\end{array}$

SAVINGS-TO-INVESTMENT RATIOS FOR SOLAR SCREENS (COST $=\$ 6.0 / 50$. FT., U=0.50)

$\begin{array}{crrrrrr}\text { HEATING ENERGY }= & S C=0.1 & S C=0.2 & S C=0.4 & S C=0.6 & S C=0.8 & S C=1.0 \\ \text { GAS } & .6 & .6 & .5 & .3 & .2 & .1 \\ \text { OIL } & .5 & .5 & .5 & .4 & .3 & .3 \\ \text { STEAM } & .5 & .5 & .5 & .4 & .3 & .2\end{array}$

30 YEAR PRESENT WORTH FACTOR $=19.3$ (GAS), 21.0(OIL), 17.4(STEAM), 15.6(ELEC) MATERIAL \& INSTALLATION COST $=\$ 252000$. 
Table 8b. Cost-effectiveness for Houston $U=0.84$, Summer-only Cooling

FIRST YEAR ENERGY SAVINGS (DOLLARS) FOR SOLAR SCREENS $(U=0.84)$

$\begin{array}{ccccrr}\text { HEATING ENERGY } & S C=0.1 & S C=0.2 & S C=0.4 & S C=0.6 & S C=0.8 \\ \text { GAS } & 8980 . & 8111 . & 6227 . & 4367 . & 2532 . \\ \text { OIL } & 6857 . & 6397 . & 5294 . & 4162 . & 2954 . \\ \text { STEAM } & 6289 . & 5938 . & 5044 . & 4107 . & 3067 .\end{array}$

ASSUMPTIONS: $\quad$ ELECTRICITY COST $=\$ .050 / \mathrm{KWH}$

HEATING FUEL COST $=\$ .015($ GAS), .038(OIL). .045(STEAM) $/ K W H$

PAY-8ACK PERIODS (YEARS) FOR SOLAR SCREENS (COST=\$1.0/SO. FT., U $=0.84$ )

\begin{tabular}{|c|c|c|c|c|c|c|}
\hline $\begin{array}{l}\text { HEATING ENERGY } \\
* * * * * * * *\end{array}$ & $\begin{array}{l}S C=0.1 \\
* \neq * \neq\end{array}$ & $S C=0.2$ & $\begin{array}{l}S C=0.4 \\
* * * * *\end{array}$ & $S C=0.6$ & $S C=0.8$ & $S C=1.0$ \\
\hline $\begin{array}{l}\text { GAS } \\
\text { OIL } \\
\text { STEAM }\end{array}$ & $\begin{array}{l}6.0 \\
7.0 \\
8.0\end{array}$ & $\begin{array}{l}6.0 \\
8.0 \\
9.0\end{array}$ & $\begin{array}{r}8.0 \\
10.0 \\
11.0\end{array}$ & $\begin{array}{l}13.0 \\
14.0 \\
14.0\end{array}$ & $\begin{array}{r}>30.0 \\
23.0 \\
22.0\end{array}$ & $\begin{array}{l}>30.0 \\
>30.0 \\
>30.0\end{array}$ \\
\hline
\end{tabular}

SAVINGS-TO-INVESTMENT RATIOS FOR SOLAR SCREENS (COST=\$1.0/SO. FT. U U =0.84)

$\begin{array}{crrrrrr}\text { HEATING ENERGY } & S C=0.1 & S C=0.2 & S C=0.4 & S C=0.6 & S C=0.8 & S C=1.0 \\ \text { GAS } & 1.8 & 1.6 & 1.2 & .9 & .5 & .1 \\ \text { CIL } & 1.4 & 1.3 & 1.1 & .8 & .6 & .3 \\ \text { STEAM } & 1.2 & 1.1 & 1.0 & .8 & .6 & .4\end{array}$

10 YEAR FRESENT WORTH FACTOR $=9.3$ (GAS), 8.O(OIL), 8.8(STEAM), 8.3(ELEC) MATERIAL \& INSTALLATION COST $=\$ 42000$.

PAY-BACK PERIODS (YEARS) FOR SOLAR SCREENS (COST $=53.0 / 50$. FT. U U $=0.84$ )

$\begin{array}{crrrrrr}\text { HEATING ENERGY } & S C=0.1 & S C=0.2 & S C=0.4 & S C=0.6 & S C=0.8 & S C=1.0 \\ \text { GAS } & 26.0 & >30.0 & >30.0 & >30.0 & >30.0 & >30.0 \\ \text { OIL } & >30.0 & >30.0 & >30.0 & >30.0 & >30.0 & >30.0 \\ \text { STEAM } & >30.0 & >30.0 & >30.0 & >30.0 & >30.0 & >30.0\end{array}$

SAVINGS-TO-INVESTMENT RATIOS FOR SOLAR SCREENS (COST $=\$ 3.0 /$ SO. FT. U U 0.84 )

\begin{tabular}{|c|c|c|c|c|c|c|}
\hline $\begin{array}{l}\text { HEATING ENERGY } \\
\text { H I }\end{array}$ & $\begin{array}{l}S C=0.1 \\
* \neq * \#\end{array}$ & $\begin{array}{l}S C=0.2 \\
* * * * *\end{array}$ & $\begin{array}{l}S C=0.4 \\
* * * * * *\end{array}$ & $\mathrm{SC}=0.6$ & $S C=0.8$ & $\begin{array}{l}S C=1.0 \\
* * * * *\end{array}$ \\
\hline $\begin{array}{l}\text { GAS } \\
\text { OIL }\end{array}$ & $\begin{array}{r}.9 \\
.7\end{array}$ & $\begin{array}{l}.8 \\
.6\end{array}$ & $\begin{array}{l}.6 \\
.5\end{array}$ & $\begin{array}{l}.4 \\
.4\end{array}$ & $\begin{array}{l}.3 \\
.3\end{array}$ & $\begin{array}{l}.1 \\
.2\end{array}$ \\
\hline STEAM & .6 & .6 & .5 & .4 & .3 & .2 \\
\hline
\end{tabular}

20 YEAR PRESENT WORTH FACTOR $=15.2$ (GAS), 14.6(OIL), 14.1(STEAM), 12.9(ELEC) MATERIAL \& INSTALLATION COST $=\$ 126000$.

PAY-BACK PERIOOS (YEARS) FOR SOLAR SCREENS (COST $=\$ 6.0 / S O$. FT . U U $=0.84$ )

\begin{tabular}{|c|c|c|c|c|c|c|}
\hline $\begin{array}{l}\text { HEATING ENERGY } \\
\end{array}$ & $\begin{array}{l}S C=0.1 \\
* \neq *\end{array}$ & $S C=0.2$ & $S C=0.4$ & $\begin{array}{l}S C=0.6 \\
\end{array}$ & $\begin{array}{l}S C=0.8 \\
\end{array}$ & $\begin{array}{l}S C=1.0 \\
*\end{array}$ \\
\hline $\begin{array}{l}\text { GAS } \\
\text { OIL }\end{array}$ & $\begin{array}{l}>30.0 \\
>30.0 \\
>30.0\end{array}$ & $\begin{array}{l}>30.0 \\
>30.0 \\
>30.0\end{array}$ & $\begin{array}{l}>30.0 \\
>30.0 \\
>30.0\end{array}$ & $\begin{array}{l}>30.0 \\
>30.0 \\
>30.0\end{array}$ & $\begin{array}{l}>30.0 \\
>30.0 \\
>30.0\end{array}$ & $\begin{array}{l}>30.0 \\
>30.0 \\
>30.0\end{array}$ \\
\hline
\end{tabular}

SAVINGS-TO-INVESTMENT RATIOS FOR SOLAR SCREENS (COST $=\$ 6.0 / 50$. FT. U $U=0.84$ )

\begin{tabular}{|c|c|c|c|c|c|c|}
\hline HEATING ENERGY & $\begin{array}{l}S C=0.1 \\
* \neq * * * *\end{array}$ & $\begin{array}{l}5 C=0.2 \\
\end{array}$ & $\begin{array}{l}S C=0.4 \\
* * *\end{array}$ & $S C=0.6$ & $\begin{array}{l}S C=0.8 \\
\end{array}$ & $\begin{array}{l}S C=1.0 \\
* * *\end{array}$ \\
\hline $\begin{array}{l}\text { GAS } \\
\text { OIL } \\
\text { STEAM }\end{array}$ & $\begin{array}{l}.5 \\
.3 \\
.4\end{array}$ & $\begin{array}{l}.5 \\
.3 \\
.3\end{array}$ & $\begin{array}{l}.4 \\
.3 \\
.3\end{array}$ & $\begin{array}{l}.3 \\
.3 \\
.3\end{array}$ & $\begin{array}{l}.2 \\
.2 \\
.2\end{array}$ & $\begin{array}{l}.0 \\
.1 \\
.1\end{array}$ \\
\hline
\end{tabular}

30 YEAR PRESENT WORTH FACTOR = 19.3(GAS). $21.0(O I L), 17.4$ (STEAM). 15.6(ELEC) MATERIAL \& INSTALLATION COST $=\$ 252000$. 
Table 8c. Sost-effectiveness for Houston $U=0.50$, A11-year Cooling FIRST YEAR ENERGY SAVINGS (DOLLARS) FOR SOLAR SCREENS (U=ø.5ø)

\begin{tabular}{|c|c|c|c|c|c|c|}
\hline $\begin{array}{l}\text { HEATI } 1 \text { NG ENERGY } \\
\text { EN* }\end{array}$ & $\begin{array}{l}S C=\varnothing, 1 \\
\star \star \star \star \star \star \star\end{array}$ & $\begin{array}{l}S C=\emptyset \cdot 2 \\
\star \star \star * \star *\end{array}$ & $\begin{array}{l}S C=\varnothing .4 \\
\star * * * * *\end{array}$ & $\begin{array}{l}S C=\varnothing .6 \\
\star \star * \star * *\end{array}$ & $\begin{array}{l}S C=\varnothing .8 \\
\star \star \star \star \star \star *\end{array}$ & $\begin{array}{l}S C=1 . \varnothing \\
\star \star \star \star \star \star\end{array}$ \\
\hline $\begin{array}{c}\text { GAS } \\
\text { OIL } \\
\text { STEAM }\end{array}$ & $\begin{array}{l}14375 \\
12649 \\
12187\end{array}$ & $\begin{array}{l}13093 . \\
11985 . \\
11689 .\end{array}$ & $\begin{array}{l}10650 . \\
10866 . \\
10848 .\end{array}$ & $\begin{array}{l}6905 . \\
7701 . \\
7913 .\end{array}$ & $\begin{array}{l}3224 . \\
4665 . \\
5851 .\end{array}$ & $\begin{array}{l}-423 . \\
1670 . \\
2230 .\end{array}$ \\
\hline
\end{tabular}

ASSUMPTIONS: $\quad$ ELECTRICITY COST $=\$ .050 / \mathrm{KWH}$

HEAT1NG FUEL COST $=\$ .015(\mathrm{GAS}), .038(01 \mathrm{~L}), .045($ STEAM) $/ \mathrm{KWH}$

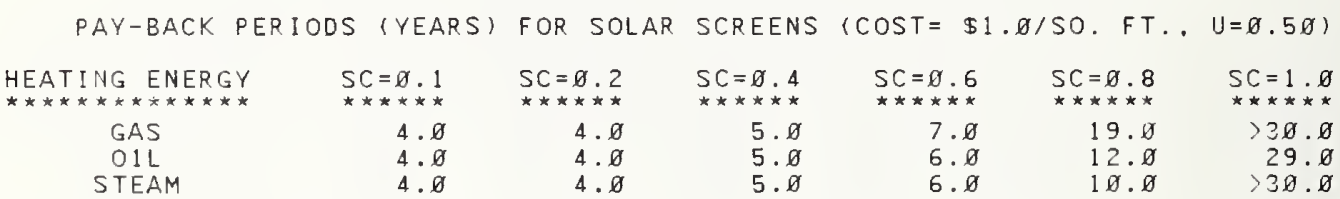

SAVINGS-TO-!NVESTMENT RATIOS FOR SOLAR SCREENS (COST $=\$ 1 . \varnothing / 50$. FT., U $=\varnothing .5 \not)$

\begin{tabular}{|c|c|c|c|c|c|c|}
\hline 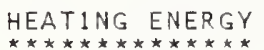 & 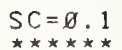 & $\begin{array}{l}S C=\varnothing .2 \\
* \star * \star * * *\end{array}$ & $\begin{array}{l}S C=\varnothing .4 \\
* * * * * *\end{array}$ & $\begin{array}{l}S C=\varnothing .6 \\
* * * * *\end{array}$ & $\begin{array}{l}S C=8.8 \\
* * *\end{array}$ & $\begin{array}{l}S C=1 \cdot \varnothing \\
* * * * *\end{array}$ \\
\hline $\begin{array}{l}\text { GAS } \\
\text { O1L }\end{array}$ & $\begin{array}{l}2.8 \\
2.5\end{array}$ & $\begin{array}{r}2.6 \\
2.4 \\
2.3\end{array}$ & 2. 1 & 1. 4 & $\begin{array}{r}.7 \\
.9\end{array}$ & $---\frac{-}{3}$ \\
\hline STEAM & 2.4 & 2.3 & 2.2 & 1.6 & $1 . \varnothing$ & \\
\hline
\end{tabular}

10 YEAR PRESENT WORTH FACTOR = 9.3(GAS), 8. (OIL), 8.8(STEAM), 8.3(ELEC) MATERIAL \& INSTALLATION COST $=\$ 42000$.

PAY-BACK PERIODS (YEARS) FOR SOLAR SCREENS (COST $=\$ 3 . \varnothing / S O$. FT. $! y=\not 1.50$ )

\begin{tabular}{|c|c|c|c|c|c|c|}
\hline 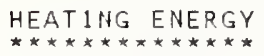 & $\begin{array}{l}S C=\varnothing .1 \\
\star \star \star \star * * *\end{array}$ & $\begin{array}{l}S C=\emptyset \cdot 2 \\
* * * * * *\end{array}$ & $\begin{array}{l}S C=\varnothing .4 \\
\star * * \star * *\end{array}$ & $\begin{array}{l}S C=\varnothing .6 \\
* \star \star \star * *\end{array}$ & $\begin{array}{l}S C=\not .8 \\
* * * * * *\end{array}$ & $\begin{array}{l}S C=1: \varnothing \\
* * * * * *\end{array}$ \\
\hline $\begin{array}{l}\text { GAS } \\
\text { OIL }\end{array}$ & $\begin{array}{l}11.0 \\
13.0\end{array}$ & $\begin{array}{l}13.0 \\
15.0\end{array}$ & $\begin{array}{l}17.0 \\
17.0\end{array}$ & $\begin{array}{r}>30.0 \\
3 \varnothing . \varnothing\end{array}$ & $\begin{array}{l}>30.0 \\
>30.0\end{array}$ & $\begin{array}{l}>30.0 \\
>30.0\end{array}$ \\
\hline STEAM & 15.0 & 15.0 & 17.0 & $30 . \varnothing$ & $>30.0$ & $>3 \varnothing . \varnothing$ \\
\hline
\end{tabular}

SAVINGS-TO-1NVESTMENT RATIOS FOR SOLAR SCREENS (COST $=\$ 3 . \varnothing / S O . \quad F T ., \quad Z=E .5 g$ )

\begin{tabular}{|c|c|c|c|c|c|c|}
\hline 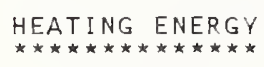 & $\begin{array}{l}S C=\emptyset .1 \\
\star \star \star \star \star \star\end{array}$ & $\begin{array}{l}S C=\varnothing .2 \\
\star \star \star \star \star \star\end{array}$ & $\begin{array}{l}S C=\varnothing .4 \\
\star * * * * *\end{array}$ & $\begin{array}{l}S C=9.6 \\
\star * \star * * \star\end{array}$ & $\begin{array}{l}S C=\pi .8 \\
* * * * *\end{array}$ & $\begin{array}{l}S C=1 . \varnothing \\
\star * * * *\end{array}$ \\
\hline $\begin{array}{l}\text { GAS } \\
\text { OIL } \\
\text { STEAM }\end{array}$ & $\begin{array}{l}1.5 \\
1.3 \\
1.2\end{array}$ & $\begin{array}{l}1.3 \\
1.2 \\
1.2\end{array}$ & $\begin{array}{l}1.1 \\
1.1 \\
1.1\end{array}$ & $\begin{array}{l}.7 \\
.8 \\
.8\end{array}$ & $\begin{array}{l}.3 \\
.5 \\
.5\end{array}$ & .2 \\
\hline
\end{tabular}

20 VEAR PRESENT WORTH FACTOR = 15.2 (GAS), 14.6 (OIL), 14.1 (STEAM), 12.9 (ELEC) MATERIAL \& INSTALLATION COST $=\$ 1260 \%$.

PAY-EACK PERIODS (YEARS) FOR SOLAR SCREENS (COST $=\$ 6.0 / 50 . \quad F T . \quad U=\varnothing .5 \varnothing)$

\begin{tabular}{|c|c|c|c|c|c|c|}
\hline 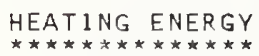 & $\begin{array}{l}S C=\not \cdot 1 \\
S_{\star \star * * \star * *}\end{array}$ & $\begin{array}{l}S C=\not .2 \\
S_{\star \star \star *} \cdot 2\end{array}$ & $\begin{array}{l}\mathrm{SC}=\varnothing .4 \\
\star * \star \star \star * *\end{array}$ & $\begin{array}{l}S C=\emptyset .6 \\
\star * * * * *\end{array}$ & $\begin{array}{l}S C=\emptyset .8 \\
\star \star \star \star \star \star \star *\end{array}$ & $\begin{array}{l}S C=1 . \varnothing \\
\star \star \star \star \star \star\end{array}$ \\
\hline $\begin{array}{l}\text { GAS } \\
\text { OIL }\end{array}$ & $\begin{array}{l}>30 . \varnothing \\
>30.0\end{array}$ & $\begin{array}{l}>30.0 \\
>30.0\end{array}$ & $\begin{array}{l}>30 . \varnothing \\
>30 . \varnothing\end{array}$ & $\begin{array}{l}>30 . \varnothing \\
>30 . \varnothing\end{array}$ & $\begin{array}{l}>30.0 \\
>30.0\end{array}$ & $\begin{array}{l}>30.0 \\
>30.0\end{array}$ \\
\hline STEAM & $>3 \varnothing . \varnothing$ & $>30.0$ & $>30 . \varnothing$ & $>3 \varnothing . \varnothing$ & $>30 . \varnothing$ & $>30.0$ \\
\hline
\end{tabular}

SAVINGS-FO-1NVESTMENT RATIOS FOR SOLAR SCREENS (COST $=\$ 6 . \varnothing / 50 . \quad F T ., U=\varnothing .50$ )

\begin{tabular}{|c|c|c|c|c|c|c|}
\hline 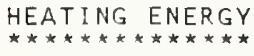 & $\begin{array}{l}S C=\varnothing \cdot 1 \\
* * * * * *\end{array}$ & $\begin{array}{l}S C=\emptyset .2 \\
\star \star \star \star \star \star *\end{array}$ & $\begin{array}{l}S C=\varnothing .4 \\
\star \star \star \star * *\end{array}$ & $\begin{array}{l}S C=\varnothing .6 \\
\star \star \star \star \star \star \star\end{array}$ & $\begin{array}{l}S C=\varnothing .8 \\
\star \star \star \star \star \star \star\end{array}$ & $\begin{array}{l}S C=1 . \varnothing \\
* * * * *\end{array}$ \\
\hline $\begin{array}{l}\text { GAS } \\
\text { O1L } \\
\text { STEAM }\end{array}$ & $\begin{array}{l}.9 \\
.7 \\
.7\end{array}$ & $\begin{array}{l}.8 \\
.7 \\
.7\end{array}$ & $\begin{array}{l}.7 \\
.7 \\
.7\end{array}$ & $\begin{array}{l}.4 \\
.5 \\
.5\end{array}$ & $\begin{array}{l}.2 \\
.3 \\
.3\end{array}$ & $\begin{array}{r}--- \\
.2 \\
.2\end{array}$ \\
\hline
\end{tabular}

30 VEAR PRESENT WORTH FACTOR $=19.3$ (GAS), 21.0(O1L). 17.4(STEAM), 15.6(ELEC) MATERIAL \& INSTALLATION COST = \$252000. 
Table 8d. Cost-effectiveness for Houston $U=0.84$, All-year Cooling

FIRST YEAR ENERGY SAVINGS (DOLLARS) FOR SOLAR SCREENS $(U=\varnothing .84$ )

\begin{tabular}{|c|c|c|c|c|c|c|}
\hline 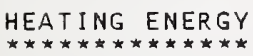 & 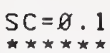 & $\begin{array}{l}S C=0.2 \\
* * * * * *\end{array}$ & SC $=\varnothing, 4$ & $S C=\varnothing, 6$ & $S C=\varnothing .8$ & $S C=1.0$ \\
\hline $\begin{array}{l}\text { GAS } \\
\text { OIL }\end{array}$ & $\begin{array}{l}13108 . \\
10091 .\end{array}$ & $\begin{array}{r}11963 . \\
9571 .\end{array}$ & $\begin{array}{l}9754 . \\
8626 .\end{array}$ & $\begin{array}{l}6475 . \\
6046 .\end{array}$ & $\begin{array}{l}3198 . \\
3497 .\end{array}$ & $\begin{array}{l}-42 \\
950\end{array}$ \\
\hline STEAM & 9283. & 8931. & 8324. & 5932. & 3577 . & 1216 \\
\hline
\end{tabular}

ASSUMPTIONS: $\quad$ ELECTRICITY COST $=\$ . \varnothing 5 . / \mathrm{KWH}$

HEATING FUEL COST $=\$ . \varnothing 15(\mathrm{GAS}), .038(0 I L), .945$ (STEAM)/KWH

PAY-BACK PERIODS (YEARS) FOR SOLAR SCREENS (COST $=$ T1.Ø/SO. FT. U U

\begin{tabular}{|c|c|c|c|c|c|c|}
\hline HEAT ING ENERGY & $\begin{array}{l}S C=\varnothing, 1 \\
S C=* * x\end{array}$ & $S C=\varnothing .2$ & $S C=\varnothing .4$ & $S C=0.6$ & $S C=0.8$ & $\begin{array}{l}S C=1 . \varnothing \\
\star * * * * *\end{array}$ \\
\hline $\begin{array}{l}\text { GAS } \\
\text { OIL }\end{array}$ & $\begin{array}{l}4.0 \\
5.0\end{array}$ & $\begin{array}{l}4.0 \\
5.0\end{array}$ & $\begin{array}{l}5.0 \\
6.0\end{array}$ & 8.0 & $\begin{array}{l}21.0 \\
18.0\end{array}$ & $\begin{array}{l}>30.0 \\
>30.0\end{array}$ \\
\hline STEAM & $5 . \varnothing$ & 6.0 & 6.0 & $9 . \varnothing$ & 17.0 & $>30.0$ \\
\hline
\end{tabular}

SAVINGS-TO-INVESTMENT RATIOS FOR SOLAR SCREENS (COST $=\$ 1 . \varnothing / S O . \quad F T, U=\varnothing .84$ )

\begin{tabular}{|c|c|c|c|c|c|c|}
\hline 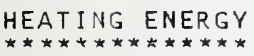 & $\begin{array}{l}S C=\theta \cdot 1 \\
\star \star \star \star * \star *\end{array}$ & 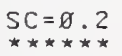 & $\begin{array}{l}S C=\varnothing \cdot 4 \\
\star \star \star \star \star \star * \star *\end{array}$ & $\begin{array}{l}S C=\varnothing .6 \\
\star * * * \star *\end{array}$ & $\underset{* * * x * *}{S C}=x \cdot 8$ & $\underset{* x * x * x}{S C}=1 . \varnothing$ \\
\hline $\begin{array}{l}\text { GAS } \\
\text { OIL }\end{array}$ & $\begin{array}{l}2.6 \\
2.0\end{array}$ & $\begin{array}{l}2.3 \\
1.9\end{array}$ & $\begin{array}{l}1.9 \\
1.7\end{array}$ & $\begin{array}{l}1.3 \\
1.2\end{array}$ & $\begin{array}{l}.6 \\
.7\end{array}$ &.$\varnothing$ \\
\hline
\end{tabular}

10 YEAR PRESENT WORTH FACTOR $=9.3$ (GAS), $8.0($ IL), 8.8 (STEAM), 8.3 (ELEC) MATERIAL \& INSTALLATION COST $=\$ 42000$.

PAY-BACK PERIODS (YEARS) FOR SOLAR SCREENS (COST $=\$ 3.0 / 5 O . F T, U=\varnothing .84$ )

\begin{tabular}{|c|c|c|c|c|c|c|}
\hline 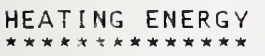 & $\begin{array}{l}S C=\varnothing .1 \\
\star \star \star \star \star \star *\end{array}$ & $\begin{array}{l}S C=\varnothing, 2 \\
* * * * * *\end{array}$ & 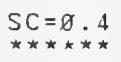 & $\begin{array}{l}S C=\not x \cdot 6 \\
\star \star \star \star \star \star *\end{array}$ & $\begin{array}{l}S C=\infty .8 \\
\star \star \star \star \star \star \star *\end{array}$ & $\begin{array}{l}S C=1.0 \\
S_{\star * \star *}\end{array}$ \\
\hline $\begin{array}{l}\text { GAS } \\
\text { OIL } \\
\text { SIEAM }\end{array}$ & $\begin{array}{l}13.0 \\
24.0\end{array}$ & $\begin{array}{l}15.0 \\
29.0 \\
28.0\end{array}$ & $\begin{array}{r}21.0 \\
>30.0 \\
>30.0\end{array}$ & $\begin{array}{l}>3 \theta . \theta \\
>30.0\end{array}$ & $\begin{array}{l}>30.0 \\
>30.0\end{array}$ & $\begin{array}{l}>30.0 \\
>30.0\end{array}$ \\
\hline
\end{tabular}

SAVINGS-TO-INVESTMENT RATIOS FOR SOLAR SCREENS (COST $=\$ 3 . \varnothing / 50$. FT. $U=\ell .84$ )

\begin{tabular}{|c|c|c|c|c|c|c|}
\hline 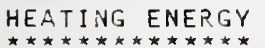 & $S C=\not D .1$ & $S C=\mathfrak{g} \cdot 2$ & $S C=\varnothing .4$ & $S C=0.6$ & $S C=\varnothing .3$ & $S C=1 . \varnothing$ \\
\hline GAS & 1.3 & 1.2 & 1. & .7 & .3 &.$\varnothing$ \\
\hline OIL & 1.0 & .9 & .9 & .6 & .4 & .1 \\
\hline STEAM & .9 & .9 & .8 & .6 & .4 & .1 \\
\hline
\end{tabular}

20 YEAR PRESENT WCRTH FACTOR = 15.2(GAS), 14.6 (OIL), 14.1(STEAM), 12.9(E)EC) MATERIAL \& INSTALLATION COST $=\$ 1260 \times 9$.

PAY-BACK PERIODS (YEARS) FOR SOLAR SCREENS (COST $=\$ 6.0 / S O$. FT., J $=\varnothing .84$ )

\begin{tabular}{|c|c|c|c|c|c|c|}
\hline 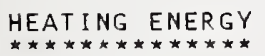 & $\begin{array}{l}S C=\varnothing \cdot 1 \\
\star * * * * *\end{array}$ & $\begin{array}{l}S C=\varnothing .2 \\
* * * * * *\end{array}$ & $\begin{array}{l}S C=\emptyset \cdot 4 \\
\star \star \star \star \star \star \star\end{array}$ & $\begin{array}{l}S C=\varnothing .6 \\
S * \star \star * \star *\end{array}$ & $S C=\not .8$ & $S C=1 . \theta$ \\
\hline $\begin{array}{l}\text { GAS } \\
\text { OIL } \\
\text { STEAM }\end{array}$ & $\begin{array}{l}>3 \varnothing . \varnothing \\
>30 . \varnothing \\
>3 \varnothing . \varnothing\end{array}$ & $\begin{array}{l}>30.0 \\
>30.0 \\
>30.0\end{array}$ & $\begin{array}{l}>30.0 \\
>30.0 \\
>30.0\end{array}$ & $\begin{array}{l}>3 \theta . \varnothing \\
>3 \varnothing .0 \\
>30.0\end{array}$ & $\begin{array}{l}>3 \varnothing . \varnothing \\
>3 \varnothing . \varnothing \\
>30 . \varnothing\end{array}$ & $\begin{array}{l}>30.0 \\
>30.0 \\
>30.0\end{array}$ \\
\hline
\end{tabular}

SAVINGS-TO-INVESTMENT PATIOS FOR SOLAR SCREENS (COST $=\$ 6 . \varnothing / 50 . \quad F T \ldots, U=\varnothing .84$ )

\begin{tabular}{|c|c|c|c|c|c|c|}
\hline 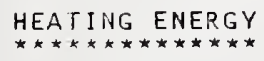 & $\begin{array}{l}S C=\emptyset, 1 \\
\star \star \star \star \star \star\end{array}$ & $\begin{array}{l}\text { SC }=0.2 \\
\star \star \star \star \star \star\end{array}$ & $\begin{array}{l}S C=\varnothing .4 \\
\star \star \star \star \star \star\end{array}$ & $\begin{array}{l}\mathrm{SC}=\emptyset .6 \\
\star \star \star \star \star \star\end{array}$ & $\begin{array}{l}S C=0.8 \\
\star \star \star \star * \star *\end{array}$ & $\begin{array}{l}S C=1.0 \\
\text { SC******}\end{array}$ \\
\hline $\begin{array}{l}\text { GAS } \\
\text { OIL } \\
\text { STEAM }\end{array}$ & $\begin{array}{l}.8 \\
.5 \\
.5\end{array}$ & $\begin{array}{l}.7 \\
.5 \\
.5\end{array}$ & $\begin{array}{l}.5 \\
.5 \\
.5\end{array}$ & $\begin{array}{l}.4 \\
.4 \\
.4\end{array}$ & $\begin{array}{l}.2 \\
.2 \\
.2\end{array}$ & $\begin{array}{l}.0 \\
.1 \\
.1\end{array}$ \\
\hline
\end{tabular}

30 YEAR PRESENT WORTH FACTOR = 19.3(GAS), 21.0(OIL), 17.4(STEAM), 15.6(ELEC) MATER IAL \& INSTALLATION COST $=\$ 252000$. 


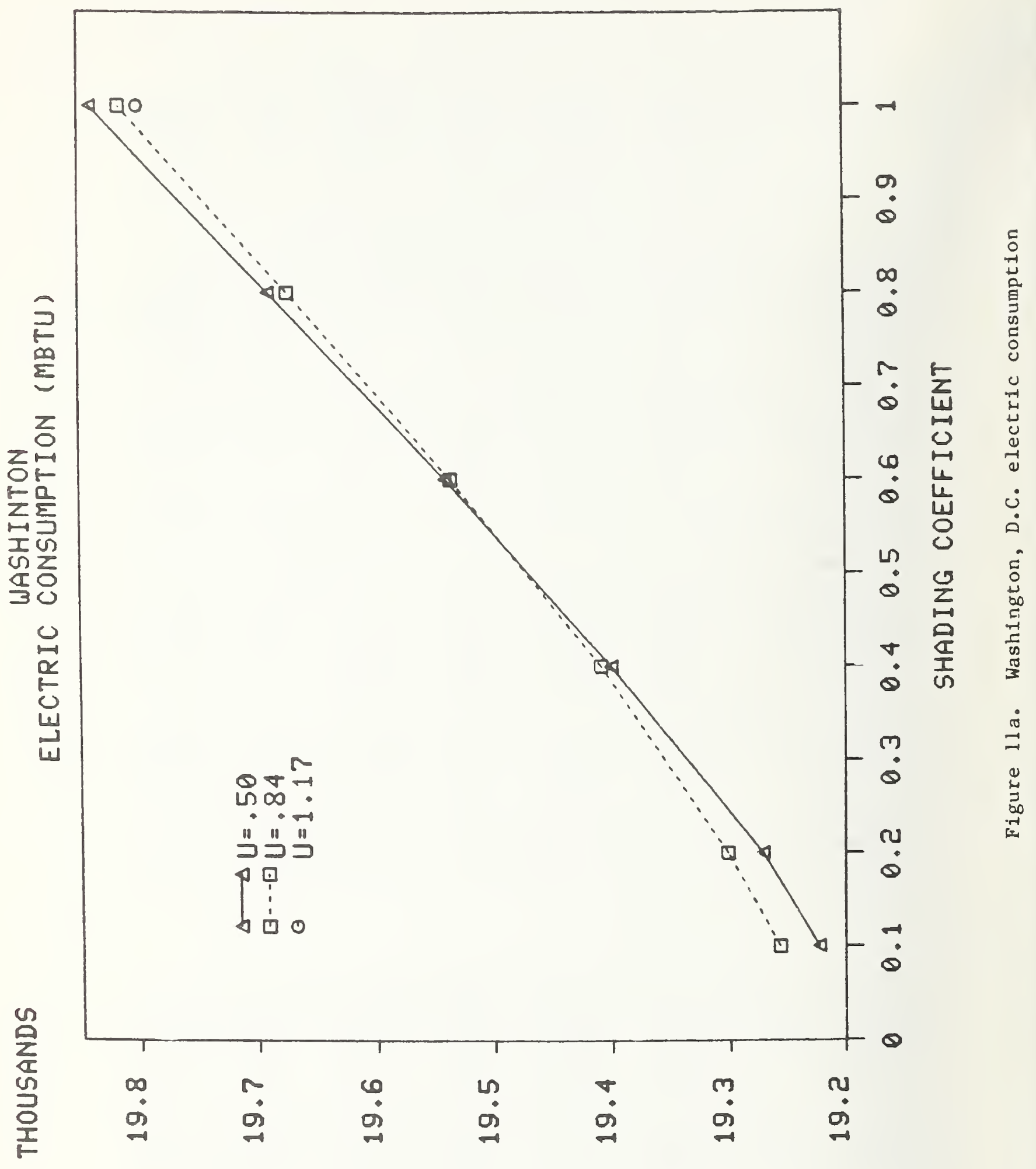

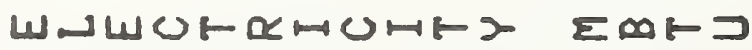




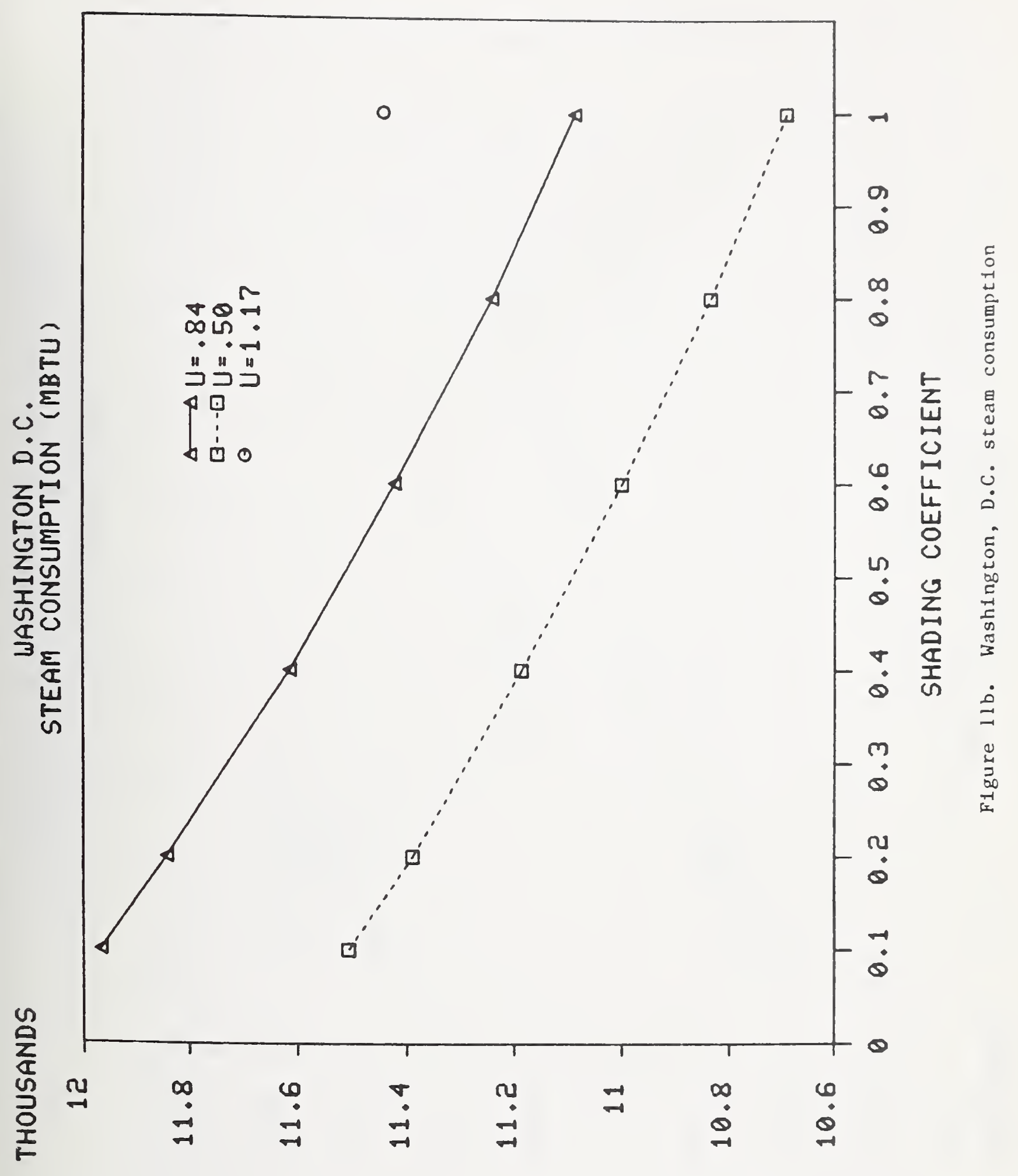

URW IE 


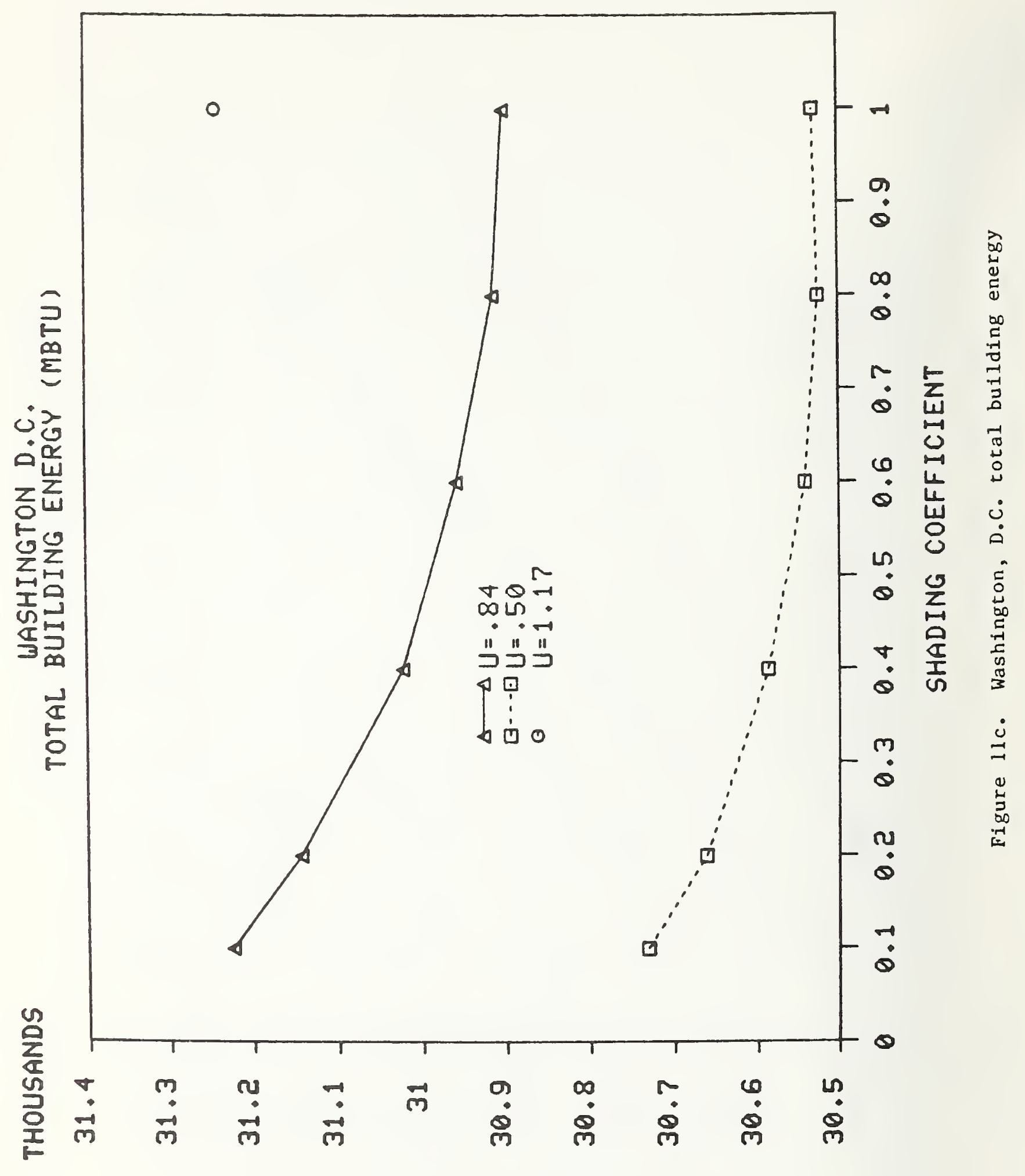

tota. 


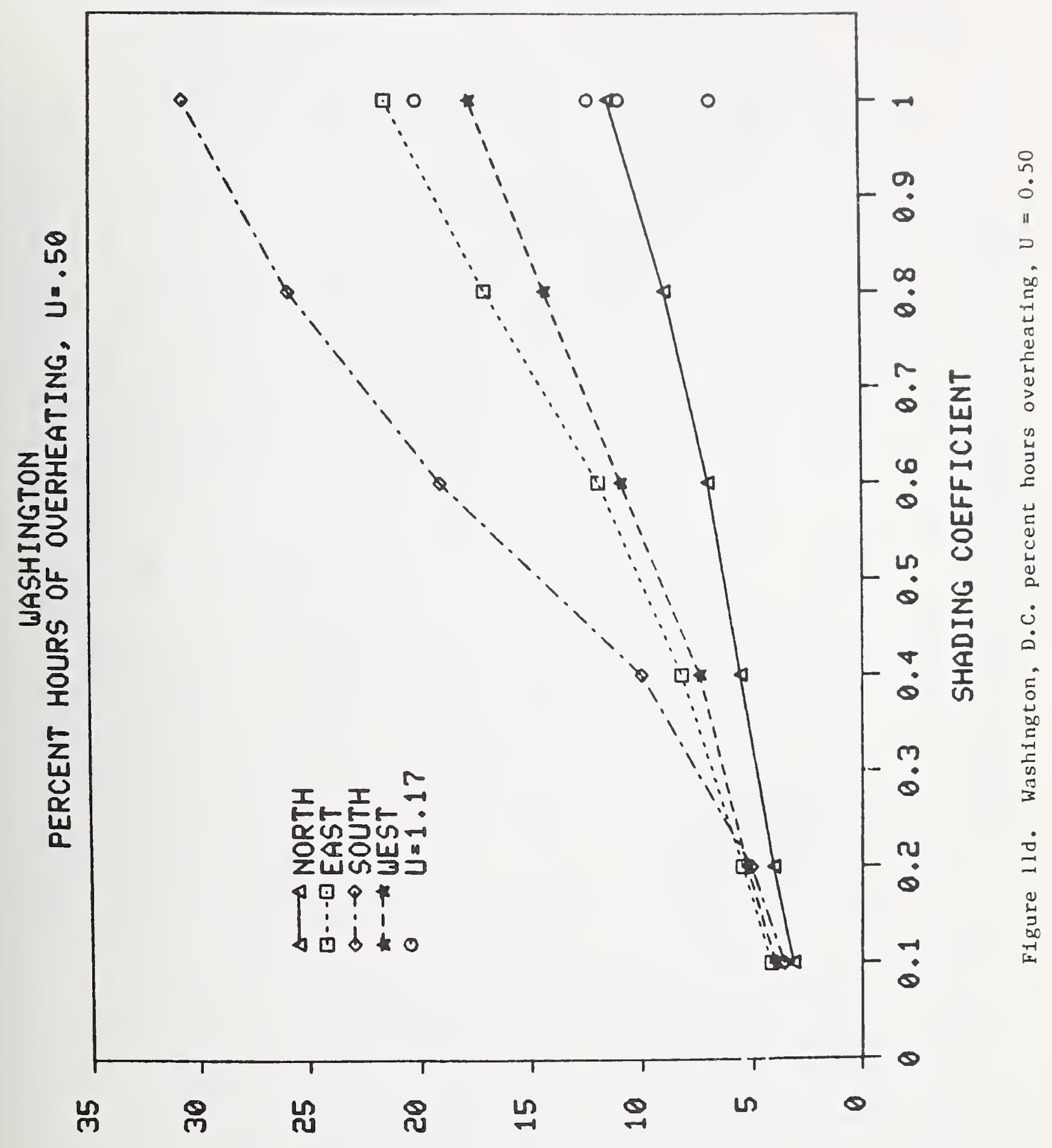

யऽலயட 


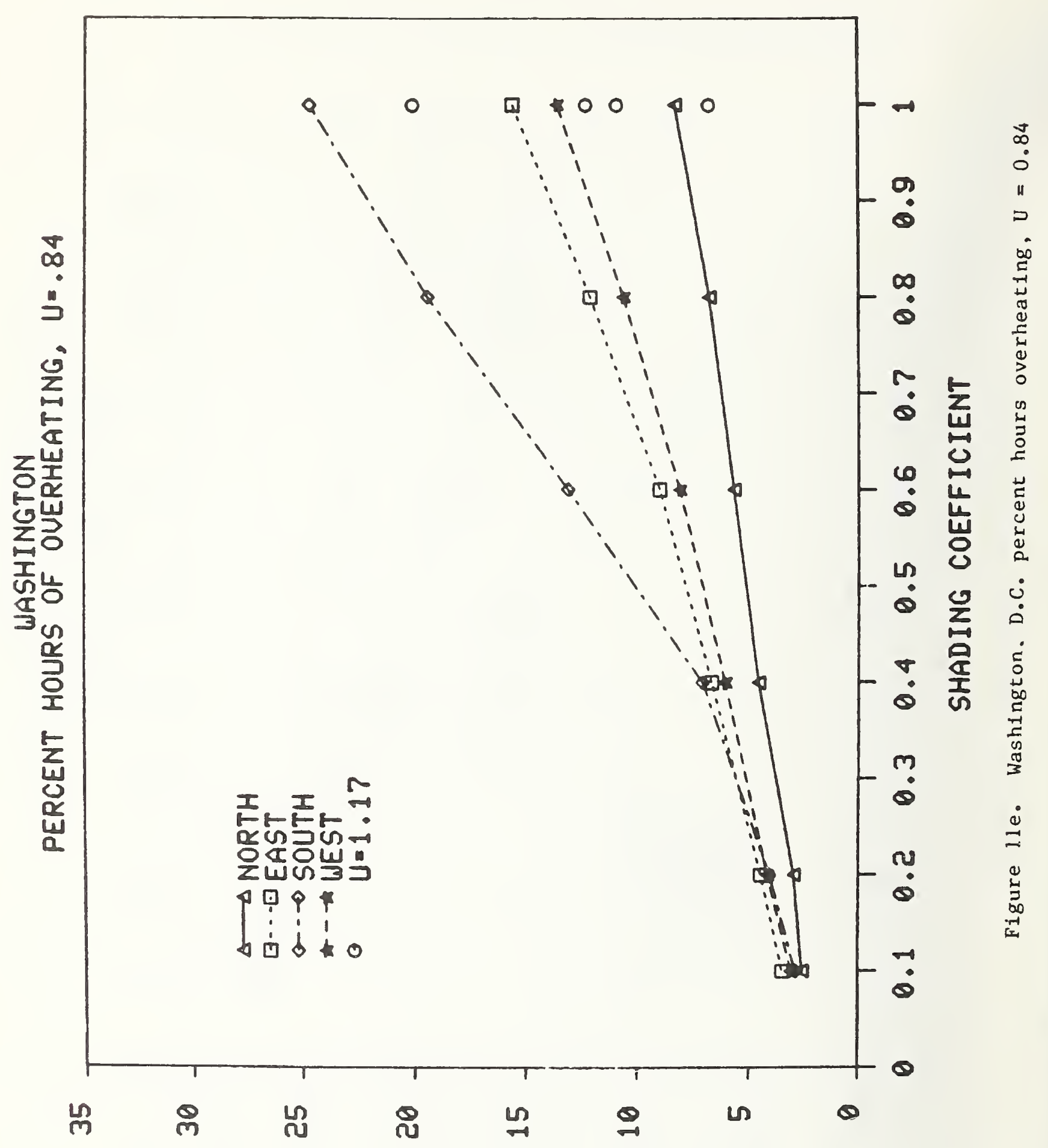

aw口OWZR 
Table 9a. Cost-effectiveness for Washington, D.C. $U=0.50$, Sumer-only Cooling

FIRST YEAR ENERGY SAVINGS (DOLLARS) FOR SOLAR SCREENS $(U=0.50)$

$\begin{array}{clllrrr}\text { HEATING ENERGY } & \text { SC=0.1 } & \text { SC=0.2 } & \text { SC=0.4 } & \text { SC=0.6 } & \text { SC=0.8 } & S C=1.0 \\ \text { GAS } & 11782 . & 11722 . & 10663 . & 9193 . & 7387 . & 5370 . \\ \text { OIL } & 11605 . & 11867 . & 11364 . & 10404 . & 9050 . & 7427 . \\ \text { STEAM } & 11473 . & 11974 . & 11882 . & 11300 . & 10280 . & 8949 .\end{array}$

ASSUMPTIONS: $\quad$ ELECTRICITY COST $=\$ .073 / \mathrm{KWH}$

HEATING FUEL COST $=\$ .028$ (GAS). .038(OIL), .045(STEAM)/KWH

PAY-8ACK PERIODS (YEARS) FOR SOLAR SCREENS (COST $=\$ 1.0 / S O$. FT. U $=0.50$ )

\begin{tabular}{|c|c|c|c|c|c|c|}
\hline HEATING ENERGY & $S C=0.1$ & $\mathrm{SC}=0.2$ & $S C=0.4$ & $S C=0.6$ & $S C=0.8$ & $S C=1.0$ \\
\hline $\begin{array}{l}\text { GAS } \\
\text { OIL } \\
\text { STEAM }\end{array}$ & $\begin{array}{l}4.0 \\
4.0 \\
4.0\end{array}$ & $\begin{array}{l}4.0 \\
4.0 \\
4.0\end{array}$ & $\begin{array}{l}5.0 \\
4.0\end{array}$ & $\begin{array}{l}5.0 \\
5.0 \\
4.0\end{array}$ & $\begin{array}{l}6.0 \\
6.0\end{array}$ & $\begin{array}{l}8.0 \\
7.0\end{array}$ \\
\hline
\end{tabular}

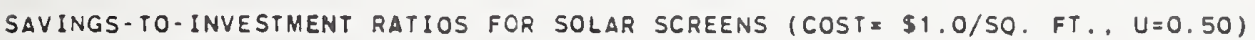

$\begin{array}{crrrrrr}\text { HEATING ENERGY } & \text { SC=0.1 } & \text { SC=0.2 } & \text { SC=0.4 } & \text { SC=0.6 } & S C=0.8 & S C=1.0 \\ \text { GAS } & 2.3 & 2.4 & 2.2 & 2.0 & 1.6 & 1.3 \\ \text { OIL } & 2.3 & 2.4 & 2.2 & 2.0 & 1.7 & 1.4 \\ \text { STEAM } & 2.3 & 2.4 & 2.4 & 2.3 & 2.1 & 1.9\end{array}$

10 YEAR PRESENT WORTH FACTOR = 9.8(GAS). 8.O(OIL). 8.9(STEAM). 8.4(ELEC) MATERIAL \& INSTALLATION COST $=\$ 42000$.

PAY-8ACK PERIODS (YEARS) FOR SOLAR SCREENS (COST $=\$ 3.0 / 50$. FT . U U=0.50)

$\begin{array}{crrrrrr}\text { HEATING ENERGY } & \text { SC=0.1 } & \text { SC=0.2 } & \text { SC=0.4 } & \text { SC=0.6 } & \text { SC=0.8 } & \text { SC= } 1.0 \\ \text { GAS } & 15.0 & 15.0 & 16.0 & 19.0 & 24.0 & >30.0 \\ \text { OIL } & 15.0 & 15.0 & 15.0 & 17.0 & 20.0 & 24.0 \\ \text { STEAM } & 15.0 & 14.0 & 14.0 & 15.0 & 17.0 & 20.0\end{array}$

SAVINGS-TO-INVESTMENT RATIOS FOR SOLAR SCREENS (COST $=\$ 3.0 / S O$. FT., $U=0.50$ )

$\begin{array}{crrrrrr}\text { HEATING ENERGY } & S C=0.1 & S C=0.2 & S C=0.4 & S C=0.6 & S C=0.8 & S C=1.0 \\ \text { GAS } & 1.2 & 1.2 & 1.2 & 1.1 & .9 & .7 \\ \text { OIL } & 1.2 & 1.2 & 1.2 & 1.1 & 1.0 & .9 \\ \text { STEAM } & 1.2 & 1.2 & 1.3 & 1.2 & 1.1 & 1.0\end{array}$

20 YEAR PRESENT WORTH FACTOR = 16.6(GAS), 14.6(OIL), 14.2(STEAM), 13.0(ELEC) MATERIAL \& INSTALLATION COST $=\$ 126000$.

PAY-BACK PERIODS (YEARS) FOR SOLAR SCREENS (COST = $\$ 6.0 / S O$. FT.. U U $=0.50$ )

$\begin{array}{ccccccc}\text { HEATING ENERGY } & S C=0.1 & S C=0.2 & S C=0.4 & S C=0.6 & S C=0.8 & S C=1.0 \\ \text { GAS } & >30.0 & >30.0 & >30.0 & >30.0 & >30.0 & >30.0 \\ \text { OIL } & >30.0 & >30.0 & >30.0 & >30.0 & >30.0 & >30.0 \\ \text { STEAM } & >30.0 & >30.0 & >30.0 & >30.0 & >30.0 & >30.0\end{array}$

SAVINGS-TO-INVESTMENT RATIOS FOR SOLAR SCREENS (COST $=\$ 6.0 /$ SO. FT. $U=0.50$ )

$\begin{array}{crrrrrr}\text { HEATING ENERGF } & S C=0.1 & S C=0.2 & S C=0.4 & S C=0.6 & S C=0.8 & S C=1.0 \\ \text { GAS } & .7 & .7 & .7 & .7 & .6 & .7 \\ \text { OIL } & .7 & .7 & .8 & .7 & .7 & .6 \\ \text { STEAM } & .7 & .7 & .8 & .7 & .7 & .6\end{array}$

30 YEAR PRESENT WORTH FACTOR $=21.4$ (GAS), 20.8(OIL), 17.5(STEAM), 15.6(ELEC) MATERIAL \& INSTALLATION COST $=\$ 252000$. 
Table 9b. Sost-effectiveness for Washington, D.C. IJ $=0.84$, Summer-only COOling

FIRST YEAR ENERGY SAVINGS (DOLLARS) FOR SOLAR SCREENS ( $U=0.84$ )

$\begin{array}{ccccccc}\text { HEATING ENERGY } & \text { SC=0.1 } & \text { SC=0.2 } & \text { SC=0.4 } & \text { SC=0.6 } & \text { SC=0.8 } & S C=1.0 \\ \text { GAS } & 7242 . & 7331 . & 6937 . & 5786 . & 4361 . & 2616 . \\ \text { OIL } & 5806 . & 6238 . & 6468 . & 5841 . & 4909 . & 3589 . \\ \text { STEAM } & 4744 . & 5430 . & 6120 . & 5883 . & 5316 . & 4309 .\end{array}$

ASSUMPTIONS: ELECTRICITY COST $=\$ .073 / \mathrm{KWH}$

HEATING FUEL COST $=\$ .028$ (GAS), .038(OIL), .045(STEAM) $/ K W H$

PAY-8ACK PERIODS (YEARS) FOR SOLAR SCREENS (COST $=\$ 1.0 / S O$. FT,$U=0.84$ )

$\begin{array}{crrrrrr}\text { HEATING ENERGY } & S C=0.1 & S C=0.2 & S C=0.4 & S C=0.6 & S C=0.8 & S C=1.0 \\ \text { GAS } & 7.0 & 7.0 & 7.0 & 9.0 & 12.0 & 19.0 \\ \text { OIL } & 8.0 & 8.0 & 8.0 & 9.0 & 11.0 & 16.0 \\ \text { SIEAM } & 13.0 & 10.0 & 8.0 & 9.0 & 9.0 & 13.0\end{array}$

SAVINGS-TO. INVESTMENT RATIOS FOR SOLAR SCREENS (COST $=\$ 1.0 /$ SO. FT., $U=0.84$ )

$\begin{array}{crrrrrr}\text { HEATING ENERGY } & S C=0.1 & S C=0.2 & S C=0.4 & S C=0.6 & S C=0.8 & S C=1.0 \\ \text { GAS } & 1.3 & 1.4 & 1.3 & 1.2 & .9 & .6 \\ \text { OIL } & 1.2 & 1.3 & 1.3 & 1.2 & 1.0 & .7 \\ \text { STEAM } & .9 & 1.0 & 1.2 & 1.2 & 1.1 & .9\end{array}$

10 YEAR PRESENT WORTH FACTOR $=9.8(G A S) .8 .0(O I L) .8 .9($ STEAM), 8.4(ELEC) MATERIAL \& INSTALLATION COST $=\$ 42000$.

PAY-BACK PERIODS (YEARS) FOR SOLAR SCREENS (COST $=\$ 3.0 / 50$. FT,$U=0.84$ )

\begin{tabular}{|c|c|c|c|c|c|c|}
\hline $\begin{array}{l}\text { HEATING ENERGY } \\
*^{*}+*^{*}+*^{*} *^{* * * *}\end{array}$ & $\begin{array}{l}S C=0.1 \\
* * * *\end{array}$ & $\begin{array}{l}S C=0.2 \\
* * * * *\end{array}$ & $\begin{array}{l}S C=0.4 \\
* * * * *\end{array}$ & $\mathrm{SC}=0.6$ & $\begin{array}{l}S C=0.8 \\
* \ldots\end{array}$ & $\begin{array}{l}S C=1.0 \\
* \ldots\end{array}$ \\
\hline $\begin{array}{l}\text { GAS } \\
\text { OIL }\end{array}$ & $\begin{array}{l}>30.0 \\
>30.0\end{array}$ & $\begin{array}{l}>30.0 \\
>30.0\end{array}$ & $\begin{array}{l}>30.0 \\
>30.0\end{array}$ & $\begin{array}{l}>30.0 \\
>30.0\end{array}$ & $\begin{array}{l}>30.0 \\
>30.0\end{array}$ & $\begin{array}{l}>30.0 \\
>30.0\end{array}$ \\
\hline STEAM & $>30.0$ & $>30.0$ & $>30.0$ & $>30.0$ & $>30.0$ & $>30.0$ \\
\hline
\end{tabular}

SAVINGS-TO-INVESTMENT RATIOS FOR SOLAR SCREENS (COST=\$3.0/SO. FT,$U=0.84$ )

$\begin{array}{crrrrrr}\text { HEATING ENERGY } & S C=0.1 & S C=0.2 & S C=0.4 & S C=0.6 & S C=0.8 & S C=1.0 \\ \text { GAS } & .6 & .7 & .7 & .6 & .5 & .4 \\ \text { OIL } & .5 & .6 & .6 & .6 & .5 & .4 \\ \text { STEAM } & .4 & .5 & .6 & .6 & .6 & .5\end{array}$

20 YEAR PRESENT WORTH FACTOR $=16.6$ (GAS), 14.6(OIL), 14.2(STEAM), 13.0(ELEC) MATERIAL \& INSTALLATION COST $=\$ 126000$.

PAY-8ACK PERIODS (YEARS) FOR SOLAR SCREENS (COST $=\$ 6.0 / 50$. FT.. U U $=0.84$ )

$\begin{array}{ccccccc}\text { HEATING ENERGY } & S C=0.1 & S C=0.2 & S C=0.4 & S C=0.6 & S C=0.8 & S C=1.0 \\ \text { GAS } & >30.0 & >30.0 & >30.0 & >30.0 & >30.0 & >30.0 \\ \text { OIL } & >30.0 & >30.0 & >30.0 & >30.0 & >30.0 & >30.0 \\ \text { STEAM } & >30.0 & >30.0 & >30.0 & >30.0 & >30.0 & >30.0\end{array}$

SAVINGS-TO-INVESISENT RATIOS FOR SOLAR SCREENS (COST $=\$ 6.0 / 50$. FT., U $=0.84$ )

$\begin{array}{crrrrrr}\text { HEATING ENERGY } & S C=0.1 & S C=0.2 & S C=0.4 & S C=0.6 & S C=0.8 & S C=1.0 \\ \text { GAS } & .3 & .4 & .4 & .4 & .3 & .2 \\ \text { OIL } & .2 & .3 & .4 & .4 & .3 & .3 \\ \text { STEAM } & .2 & .3 & .4 & .4 & .3 & .3\end{array}$

30 YEAR PRESENT WORTH FACTOR $=21.4($ GAS), 20.8(OIL), 17.5(STEAM), 15.6(ELEC) MATERIAL \& INSTALLATION COST $=\$ 252000$. 
Table 9c. Cost-effectiveness for Washington, D.C. U = 0.50, All-year Cooling

FIRST YEAR ENERGY SAVINGS (DOLLARS) FOR SOLAR SCREENS $(U=\varnothing .5 \varnothing)$

\begin{tabular}{|c|c|c|c|c|c|c|}
\hline 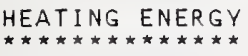 & $\begin{array}{l}S C=\varnothing, 1 \\
\star \star \star \star \star \star\end{array}$ & $\begin{array}{l}S C=\varnothing .2 \\
\star \star \star \star \star \star\end{array}$ & $\begin{array}{l}\mathrm{SC}=\varnothing, 4 \\
\star \star \star \star \star \star \star \star\end{array}$ & $\begin{array}{l}\mathrm{SC}=\varnothing .6 \\
\star \star \star \star \star \star * \star\end{array}$ & $\begin{array}{l}S C=\varnothing, 8 \\
\star \star \star \star \star \star * *\end{array}$ & $\begin{array}{l}S C=1 . \emptyset \\
\star \star \star * \star \star\end{array}$ \\
\hline $\begin{array}{l}\text { GAS } \\
\text { OIL } \\
\text { STEAM }\end{array}$ & $\begin{array}{l}21790 . \\
22063 . \\
22265 .\end{array}$ & $\begin{array}{l}\text { I } 9251 . \\
19675 . \\
19988 .\end{array}$ & $\begin{array}{l}14526 . \\
15275 . \\
1583 \% .\end{array}$ & $\begin{array}{l}10331 . \\
11411 . \\
12210 .\end{array}$ & $\begin{array}{l}6334 . \\
7824 . \\
8327 .\end{array}$ & $\begin{array}{l}2437 . \\
4423 . \\
5855 .\end{array}$ \\
\hline
\end{tabular}

ASSUMPTIONS: $\quad$ ELECTRICITY COST $=\$ .873 / \mathrm{KWH}$

HEATING FUEL COST $=\$ .028$ (GAS). $.038(0 I L), .045($ STEAM) $/ \mathrm{KWH}$

PAY-BACK PERIODS (YEARS) FOR SOLAR SCREENS (COST= $\$ 1 . \varnothing / S O . F T, \quad U=\varnothing .5 \varnothing$ )

\begin{tabular}{|c|c|c|c|c|c|c|}
\hline HEATING ENERGY & $S C=g, 1$ & $S C=\varnothing .2$ & $S C=\varnothing .4$ & $S C=\varnothing .6$ & $S C=\varnothing .8$ & $S C=1.0$ \\
\hline $\begin{array}{l}\text { GAS } \\
\text { OIL }\end{array}$ & $\begin{array}{l}2.0 \\
2.0\end{array}$ & $\begin{array}{l}3.0 \\
3.0\end{array}$ & $\begin{array}{l}3.8 \\
3.8\end{array}$ & $\begin{array}{l}5.8 \\
4.0\end{array}$ & $\begin{array}{l}7.0 \\
7.0\end{array}$ & $\begin{array}{l}16.8 \\
13.0\end{array}$ \\
\hline STEAM & 2.0 & 3.8 & 3.0 & 4.0 & 5.8 & 8.0 \\
\hline
\end{tabular}

SAVINGS-TO-INVESTMENT RATIOS FOR SOLAR SCREENS (COST $=\$ 1 . \varnothing / S O$. FT. $U=\varnothing .5 \varnothing)$

\begin{tabular}{|c|c|c|c|c|c|c|}
\hline 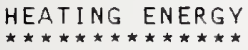 & $\begin{array}{l}S C=\not x_{* \star *} \\
S C * *\end{array}$ & $\begin{array}{l}\mathrm{SC}=\varnothing .2 \\
* * * * * *\end{array}$ & $\begin{array}{l}\mathrm{SC}=\varnothing \cdot 4 \\
* * * * * * *\end{array}$ & $\begin{array}{l}\mathrm{SC}=\varnothing .6 \\
* * * * * *\end{array}$ & $\begin{array}{l}S C=D .8 \\
\text { S }\end{array}$ & $\begin{array}{l}S C=1, \varnothing \\
* \star * * * *\end{array}$ \\
\hline $\begin{array}{l}\text { GAS } \\
\text { OIL }\end{array}$ & $\begin{array}{l}4.4 \\
\text { 4. } 4\end{array}$ & $\begin{array}{l}3.9 \\
3.9\end{array}$ & $\begin{array}{l}3.0 \\
3.0\end{array}$ & $\begin{array}{l}2.2 \\
2.2\end{array}$ & $\begin{array}{l}1.4 \\
1.5\end{array}$ & .7 \\
\hline STEAM & 4.5 & $4 . \varnothing$ & 3.2 & 2.5 & 1.9 & 1.3 \\
\hline
\end{tabular}

10 YEAR PRESENT WORTH FACTOR $=9.8($ GAS), $8.0(O I L) .8 .9$ (STEAM), 8.4 (ELEC) MATER IAL \& INSTALLATION COST $=\$ 42 \varnothing 0 \varnothing$.

PAY-BACK PERIODS (YEARS) FOR SOLAR SCREENS (COST $=\$ 3 . \varnothing / S O$. FT., U=

\begin{tabular}{|c|c|c|c|c|c|c|}
\hline HEATING ENERGY & $S C=\varnothing, 1$ & $S C=\varnothing .2$ & $S C=\varnothing .4$ & $S C=\varnothing .6$ & $S C=\varnothing .8$ & $\begin{array}{l}S C=1.8 \\
x * * * * * x\end{array}$ \\
\hline $\begin{array}{l}\text { GAS } \\
\text { OIL }\end{array}$ & $\begin{array}{r}7.0 \\
7.0\end{array}$ & $\begin{array}{r}8.0 \\
8.0\end{array}$ & $\begin{array}{l}11.0 \\
10.0\end{array}$ & $\begin{array}{l}16 . \varnothing \\
15 . \varnothing\end{array}$ & $\begin{array}{r}30.0 \\
24.0\end{array}$ & $\begin{array}{l}30.0 \\
30.0\end{array}$ \\
\hline STEAM & 7.0 & 7.0 & $1 \varnothing .0$ & 13.0 & 21.0 & $>30.0$ \\
\hline
\end{tabular}

SAVINGS-TO-INVESTMENT RATIOS FOR SOLAP. SCREENS (COST $=\$ 3 . \varnothing / S O . \quad F T, U=\varnothing .5 \varnothing)$

\begin{tabular}{|c|c|c|c|c|c|c|}
\hline HEATIIIG ENERGY & $\begin{array}{l}S C=\varnothing .1 \\
\star \star \star \star \star \star \star *\end{array}$ & $S C=\varnothing .2$ & $S C=\varnothing .4$ & $S C=\varnothing .6$ & $S C=x .8$ & $\begin{array}{l}S C=1, \mathscr{C} \\
\star \star \star \star * * * \star\end{array}$ \\
\hline $\begin{array}{l}\text { GAS } \\
\text { OIL }\end{array}$ & $\begin{array}{l}2.3 \\
2.3\end{array}$ & $\begin{array}{l}2.0 \\
2.0\end{array}$ & $\begin{array}{l}1.5 \\
1.6\end{array}$ & $\begin{array}{l}1.2 \\
1.2\end{array}$ & $\begin{array}{r}.8 \\
.9\end{array}$ & \\
\hline STEAM & 2.3 & 2.1 & 1.7 & 1.3 & $1 . \varnothing$ & \\
\hline
\end{tabular}

20 VEAR PRESENT WORTH FACTOR $=16.6$ (GAS), $14.6(O I L), 14.2$ (STEAM). 13. $($ ELEC) MATERIAL \& INSTALLATION COST $=\$ 126000$.

PAY-BACK PERIODS (YEARS) FOR SOLAR SCREENS (COST $=\$ 6 . \varnothing / S Q$. FT. U U $\varnothing .5 \varnothing$ )

\begin{tabular}{|c|c|c|c|c|c|c|}
\hline HEATIING ENERGY & $S C=\emptyset, 1$ & $S C=\varnothing .2$ & $\begin{array}{l}\mathrm{SC}=\varnothing .4 \\
\star \star \star \star \star \star \star \star\end{array}$ & $S C=\varnothing .6$ & $S C=\varnothing .8$ & $\begin{array}{l}S C=1 . \varnothing \\
\star \star \star \star \star \star * *\end{array}$ \\
\hline $\begin{array}{l}\text { GAS } \\
\text { OIL }\end{array}$ & $\begin{array}{l}16 . \not \\
16 . \varnothing\end{array}$ & 20.0 & $\begin{array}{r}>30.0 \\
30.0\end{array}$ & $\begin{array}{l}>30.0 \\
>30.0\end{array}$ & $\begin{array}{l}>30.0 \\
>30.0\end{array}$ & $\begin{array}{l}30.8 \\
>30.8\end{array}$ \\
\hline STEAM & $\begin{array}{l}16.0 \\
16.0\end{array}$ & 19.0 & $3 \varnothing . \varnothing$ & $>3 \varnothing . \varnothing$ & $>3 \varnothing . \varnothing$ & $>30.0$ \\
\hline
\end{tabular}

SAVINGS-TO-INVESTMENT RATIOS FOR SOLAR SCREENS (COST $=\$ 6 . \varnothing / S O$. FT. U U $\varnothing .5 \varnothing$ )

\begin{tabular}{|c|c|c|c|c|c|c|}
\hline 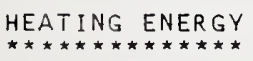 & $\begin{array}{l}S C=\varnothing \cdot 1 \\
\star \star \star \star \star \star \star *\end{array}$ & $\begin{array}{l}S C=\varnothing .2 \\
\star \star \star \star \star \star \star\end{array}$ & $\begin{array}{l}5 C=\emptyset .4 \\
\star \star \star \star \star \star *\end{array}$ & $\begin{array}{l}\text { SC }=\varnothing .6 \\
\star \star \star \star \star \star *\end{array}$ & $\begin{array}{l}S C=0.8 \\
\star \star \star \star \star \star *\end{array}$ & $\begin{array}{l}S C=1.0 \\
S * * * * * *\end{array}$ \\
\hline $\begin{array}{l}\text { GAS } \\
\text { OILL }\end{array}$ & $\begin{array}{l}1.4 \\
1.4\end{array}$ & $\begin{array}{l}1.2 \\
1.2\end{array}$ & .99 & $\begin{array}{r}.7 \\
.8 \\
8\end{array}$ & $\begin{array}{l}.5 \\
.6\end{array}$ & \\
\hline
\end{tabular}

30 YEAR PRESENT WORTH FACTOR $=21.4$ (GAS), $20.8(\mathrm{OIL}), 17.5($ STEAM), $15.6($ ELEC) MATERIAL \& INSTALLATION COST $=\$ 252000$. 
Table 9d. Cost-effectiveness for Washington, D.C. I = 0.84, All-year Cooling

FIRST YEAR ENERGY SAVINGS (DOLLARS) FOR SOLAR SCREENS ( $=\varnothing .84$ )

\begin{tabular}{|c|c|c|c|c|c|c|}
\hline 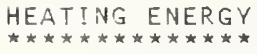 & $\begin{array}{l}\mathrm{SC}=\emptyset \cdot 1 \\
\star \star \star \star \star \star \star \star\end{array}$ & $\begin{array}{l}S C=\varnothing \cdot 2 \\
\star * * * * *\end{array}$ & $\begin{array}{l}\mathrm{SC}=\varnothing .4 \\
\star \star \star \star \star \star \star\end{array}$ & $\begin{array}{l}S C=\varnothing .6 \\
\star \star \star \star \star \star *\end{array}$ & $\begin{array}{l}S C=\varnothing \cdot 8 \\
\star \star \star \star \star * *\end{array}$ & 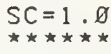 \\
\hline $\begin{array}{l}\text { GAS } \\
\text { OIL } \\
\text { STEAM }\end{array}$ & $\begin{array}{l}17426 . \\
16401 . \\
15642 .\end{array}$ & $\begin{array}{l}15439 . \\
14685 . \\
13988 .\end{array}$ & $\begin{array}{l}11243 . \\
10802 . \\
10477 .\end{array}$ & $\begin{array}{l}7979 . \\
7966 . \\
7956 .\end{array}$ & $\begin{array}{l}4748 . \\
5185 . \\
5509 .\end{array}$ & $\begin{array}{l}1692 . \\
2624 . \\
3314 .\end{array}$ \\
\hline
\end{tabular}

ASSUMPTIONS: $\quad$ ELECTRICITY COST $=\$ .073 / \mathrm{KWH}$

HEATIIHG FUEL COST $=\$ .828(\mathrm{GAS}) . .038(\mathrm{OL}), .045(\mathrm{STEAM}) / \mathrm{KWH}$

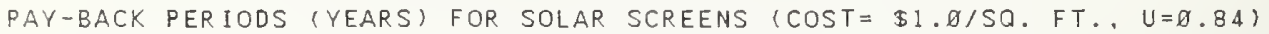

\begin{tabular}{|c|c|c|c|c|c|c|}
\hline 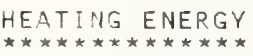 & $\begin{array}{l}S C=\emptyset .1 \\
\star \star \star \star \star \star * *\end{array}$ & $\begin{array}{l}S C=\emptyset .2 \\
\star \star \star \star * \star * *\end{array}$ & $\begin{array}{l}S C=\varnothing .4 \\
\star \star \star \star \star * * *\end{array}$ & $\begin{array}{l}S C=\theta .6 \\
\star \star \star \star \star \star \star *\end{array}$ & $\begin{array}{l}S C=\emptyset .8 \\
x_{\star}=\star \star \star *\end{array}$ & $\begin{array}{l}S C=1 . \emptyset \\
\star \star \star \star \star \star * \star\end{array}$ \\
\hline $\begin{array}{l}\text { GAS } \\
\text { OIL } \\
\text { STEAM }\end{array}$ & $\begin{array}{l}3.0 \\
3.0 \\
3.0\end{array}$ & $\begin{array}{l}3.0 \\
3.0 \\
4.0\end{array}$ & $\begin{array}{l}4.0 \\
5.0 \\
5.0\end{array}$ & $\begin{array}{l}5.0 \\
5.0 \\
6.0\end{array}$ & $\begin{array}{r}11.0 \\
10.00 \\
9.0\end{array}$ & $\begin{array}{l}30.0 \\
21.0 \\
16.0\end{array}$ \\
\hline
\end{tabular}

SAVINGS-TO-INVESTMENT RATIOS FOR SOLAR SCREENS (COST=\$1.

\begin{tabular}{|c|c|c|c|c|c|c|}
\hline 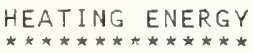 & $\begin{array}{l}S C=D, 1 \\
S_{* \star * * *}\end{array}$ & $\begin{array}{l}S C=0.2 \\
\star \star \star \star \star \star \star *\end{array}$ & 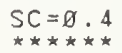 & $\underset{* * * * * *}{S C}=\not 1.6$ & 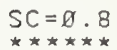 & $\underset{* * * * * *}{S C}=1 . \varnothing$ \\
\hline $\begin{array}{l}\text { GAS } \\
\text { OIL } \\
\text { STEAM }\end{array}$ & $\begin{array}{l}3.4 \\
3.3 \\
3.1\end{array}$ & $\begin{array}{l}3.0 \\
3.0 \\
2.8\end{array}$ & $\begin{array}{l}2.2 \\
2.2 \\
2.1\end{array}$ & $\begin{array}{l}1.6 \\
1.6 \\
1.6\end{array}$ & $\begin{array}{l}1.0 \\
1 . \varnothing\end{array}$ & \\
\hline
\end{tabular}

10 YEAR PRESENT WORTH FACTOR $=9.8$ (GAS), 8.ø(OIL), 8.9(STEAM), 8.4(ELEC) MATERIAL \& INSTALLATION COST $=\$ 42000$.

PAY-BACK PEPIODS (YEARS) FOR SOLAR SCREENS (COST $=\$ 3.0 / S O$. FT. U U=Ø.84)

\begin{tabular}{|c|c|c|c|c|c|c|}
\hline 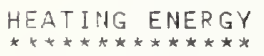 & 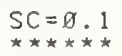 & $\begin{array}{l}S C=0.2 \\
* * * * * *\end{array}$ & $\begin{array}{l}S C=\emptyset \cdot 4 \\
\star \star \star \star \star \star \star *\end{array}$ & $\begin{array}{l}S C=\emptyset .6 \\
x * \star \star * * *\end{array}$ & $\begin{array}{l}S C=\varnothing .8 \\
* x * * * *\end{array}$ & $\begin{array}{l}S C=1 ., 0 \\
* * * * * *\end{array}$ \\
\hline $\begin{array}{l}\text { GAS } \\
\text { OIL } \\
\text { STEAM }\end{array}$ & $\begin{array}{r}9.0 \\
9.0 \\
1 \% .0\end{array}$ & $\begin{array}{l}10.0 \\
11.0 \\
12.0\end{array}$ & $\begin{array}{l}17.0 \\
17.0 \\
18.0\end{array}$ & $\begin{array}{l}>3 \theta . \theta \\
>3 \theta .0 \\
>30.0\end{array}$ & $\begin{array}{l}>30 . \varnothing \\
>30.0 \\
>3 \varnothing .0\end{array}$ & $\begin{array}{l}>30.0 \\
>30.0 \\
>30.0\end{array}$ \\
\hline
\end{tabular}

SAVINGS-TO-1NVESTMENT RATIOS FOR SOLAR SCREENS (COST= \$3. Ø/SO. FT., U=ø.84)

\begin{tabular}{|c|c|c|c|c|c|c|}
\hline 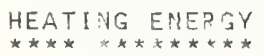 & $\begin{array}{l}\mathrm{SC}=7 \cdot 1 \\
* * * * * *\end{array}$ & $\begin{array}{l}S C=\varnothing .2 \\
* * \ldots\end{array}$ & $\begin{array}{l}S C=\varnothing \cdot 4 \\
* * * * * *\end{array}$ & $\begin{array}{l}S C=\varnothing .6 \\
S * * * *\end{array}$ & $\begin{array}{l}S C=0.8 \\
\star \star \star * * *\end{array}$ & $\begin{array}{l}S C=1 . \not \\
\star \star \star * \star * *\end{array}$ \\
\hline $\begin{array}{l}\text { GAS } \\
\text { OIL } \\
\text { STEAM }\end{array}$ & $\begin{array}{l}1.7 \\
1.6 \\
1.6\end{array}$ & $\begin{array}{l}1.5 \\
1.5 \\
1.4\end{array}$ & $\begin{array}{l}1.1 \\
1.1 \\
1.1\end{array}$ & $\begin{array}{l}.3 \\
.8 \\
.8\end{array}$ & $\begin{array}{l}.5 \\
.6 \\
.6\end{array}$ & $\begin{array}{l}.3 \\
.3 \\
.4\end{array}$ \\
\hline
\end{tabular}

20 TEAR PRESENT WORTH FACTOR = 16.6(GAS), 14.6 (OIL), 14.2(STEAH), 13. D!ELEC) MATEPIAL \& INSTALLATION COST $=\$ 126,0 \varnothing \varnothing$.

PAY-EACK PERIODS (YEARS) FOR SOLAR SCREENS (COST $=\$ 6.0 / S O$. FT, $U=\not 2.34$ )

\begin{tabular}{|c|c|c|c|c|c|c|}
\hline HEATING ENERGY & $\begin{array}{l}S C=0.1 \\
S C * * * *\end{array}$ & $\begin{array}{l}S C=\emptyset .2 \\
x_{* * * * *}\end{array}$ & $S C=\emptyset .4$ & $S C=0.6$ & $S C=\varnothing .8$ & $\begin{array}{l}S C=1.0 \\
* * * * * *\end{array}$ \\
\hline $\begin{array}{l}\text { GAS } \\
\text { OIL }\end{array}$ & $\begin{array}{r}30.0 \\
>30.0\end{array}$ & $\begin{array}{l}>3 \varnothing . \varnothing \\
>3 \varnothing . \varnothing\end{array}$ & $\begin{array}{l}>30 . \not \\
>30.0\end{array}$ & $\begin{array}{l}>30.0 \\
>30.0\end{array}$ & $\begin{array}{l}>30.0 \\
>30.0\end{array}$ & $\begin{array}{l}>30.0 \\
>30.0\end{array}$ \\
\hline
\end{tabular}

SAVINGS-TO-INVESTMENT RATIOS FOR SOLAR SCREENS (COST $=\$ 6.0 / S O . F T ., U=\varnothing .84$ )

\begin{tabular}{|c|c|c|c|c|c|c|}
\hline 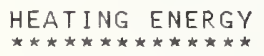 & $\begin{array}{l}S C=\emptyset .1 \\
* * * * * *\end{array}$ & $\begin{array}{l}S C=0.2 \\
\star \star \star \star \star \star \star *\end{array}$ & $\begin{array}{l}S C=\emptyset \cdot 4 \\
\star \star \star \star \star \star *\end{array}$ & $\begin{array}{l}S C=\emptyset .6 \\
\star \star \star \star \star \star \star *\end{array}$ & $\begin{array}{l}S C=\varnothing .8 \\
\star * \star \star * *\end{array}$ & $\begin{array}{l}S C=1 . \varnothing \\
* * * * *\end{array}$ \\
\hline $\begin{array}{l}\text { GAS } \\
\text { OIL }\end{array}$ & $\begin{array}{r}1.0 \\
.9\end{array}$ & .9 & 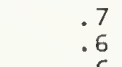 & $\begin{array}{l}.5 \\
.5 \\
\end{array}$ & $\begin{array}{l}.3 \\
.4\end{array}$ & .2 \\
\hline
\end{tabular}

30 VEAR PRESENT WORTH FACTOR $=21.4$ (GAS), $20.8(0 I L), 17.5$ (STEAM), $15.6($ ELEC) MATER. IAL \& INSTALLATION COST = \$252000. 


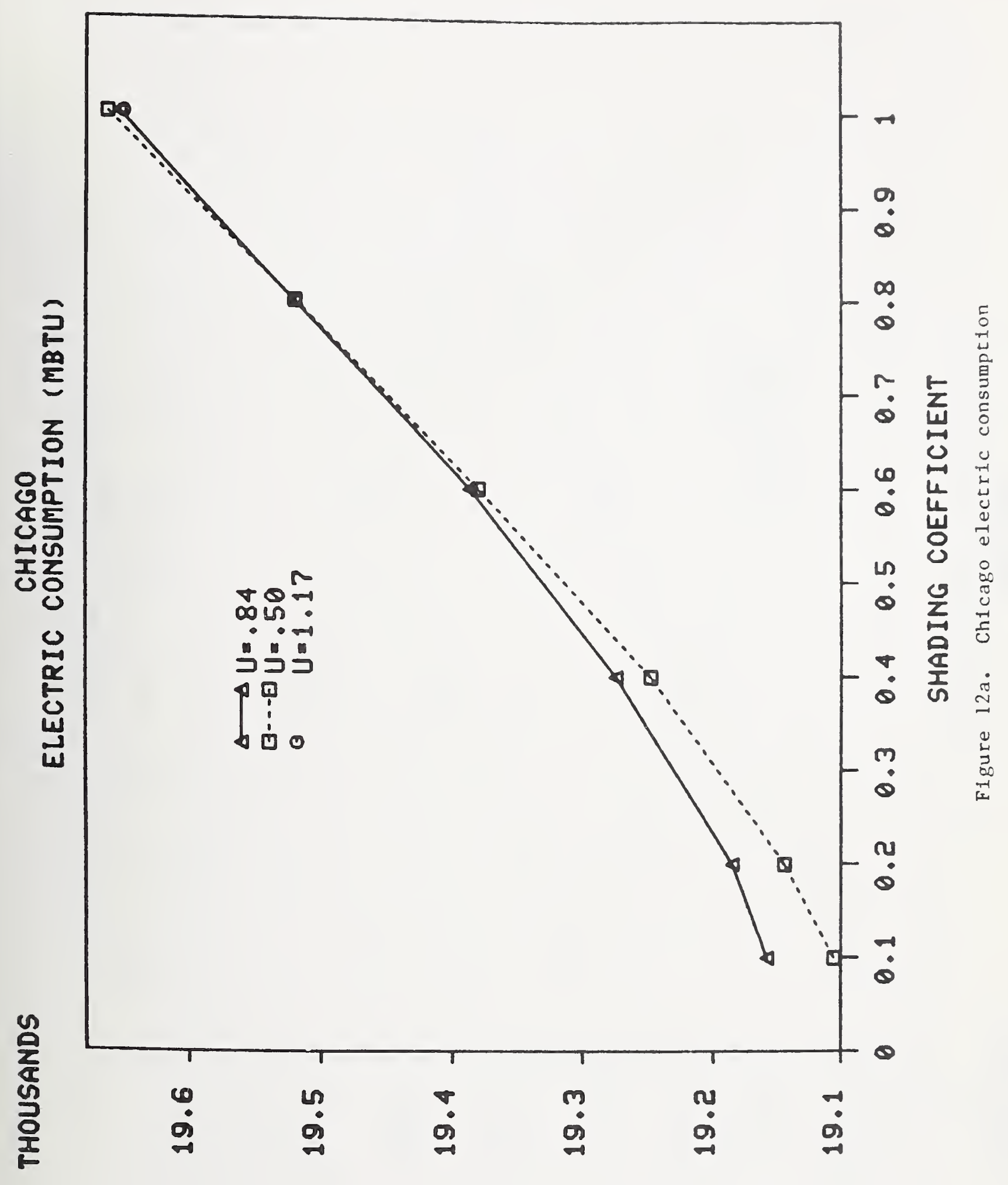

W-WOR 


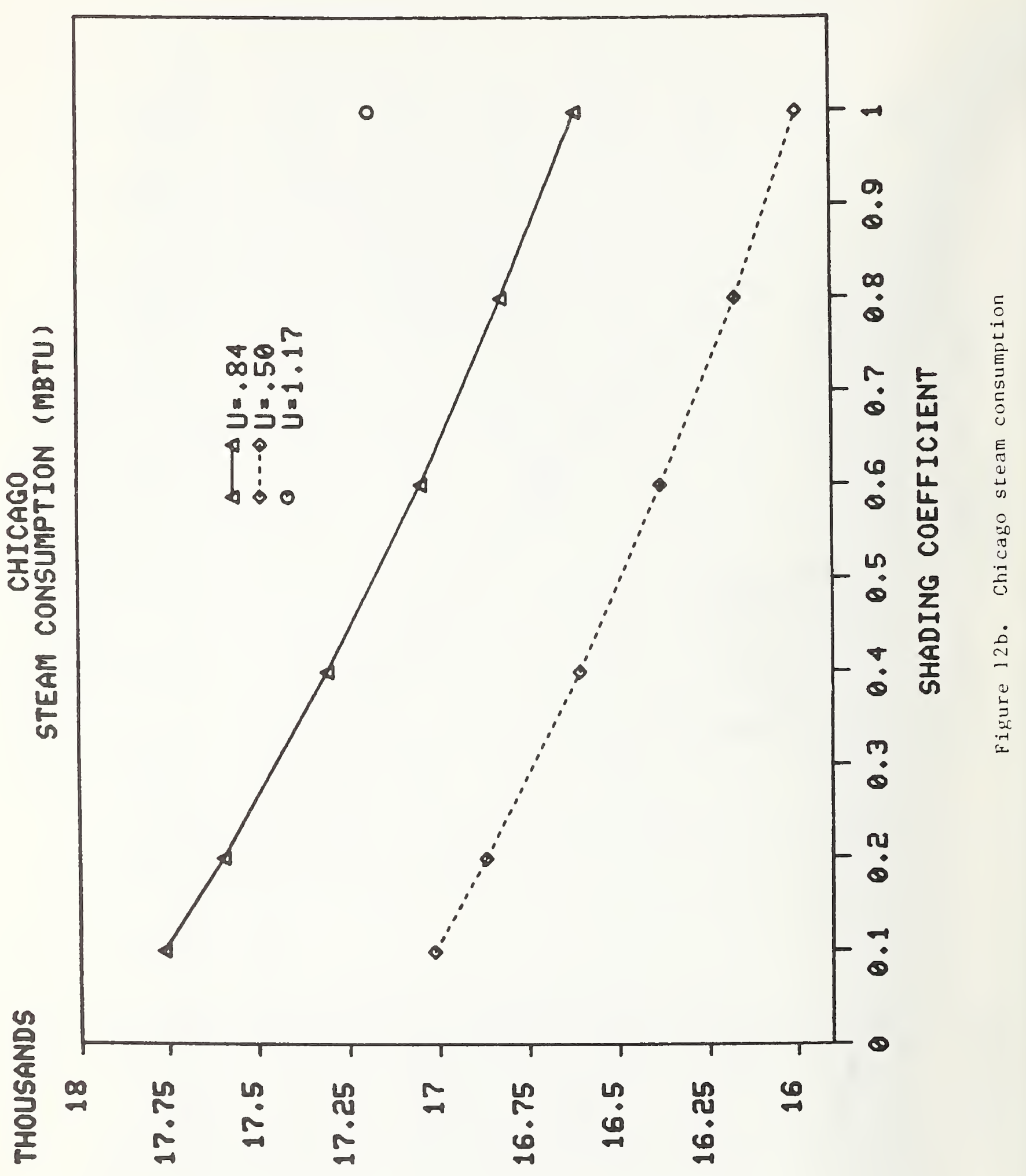

uf WCE 


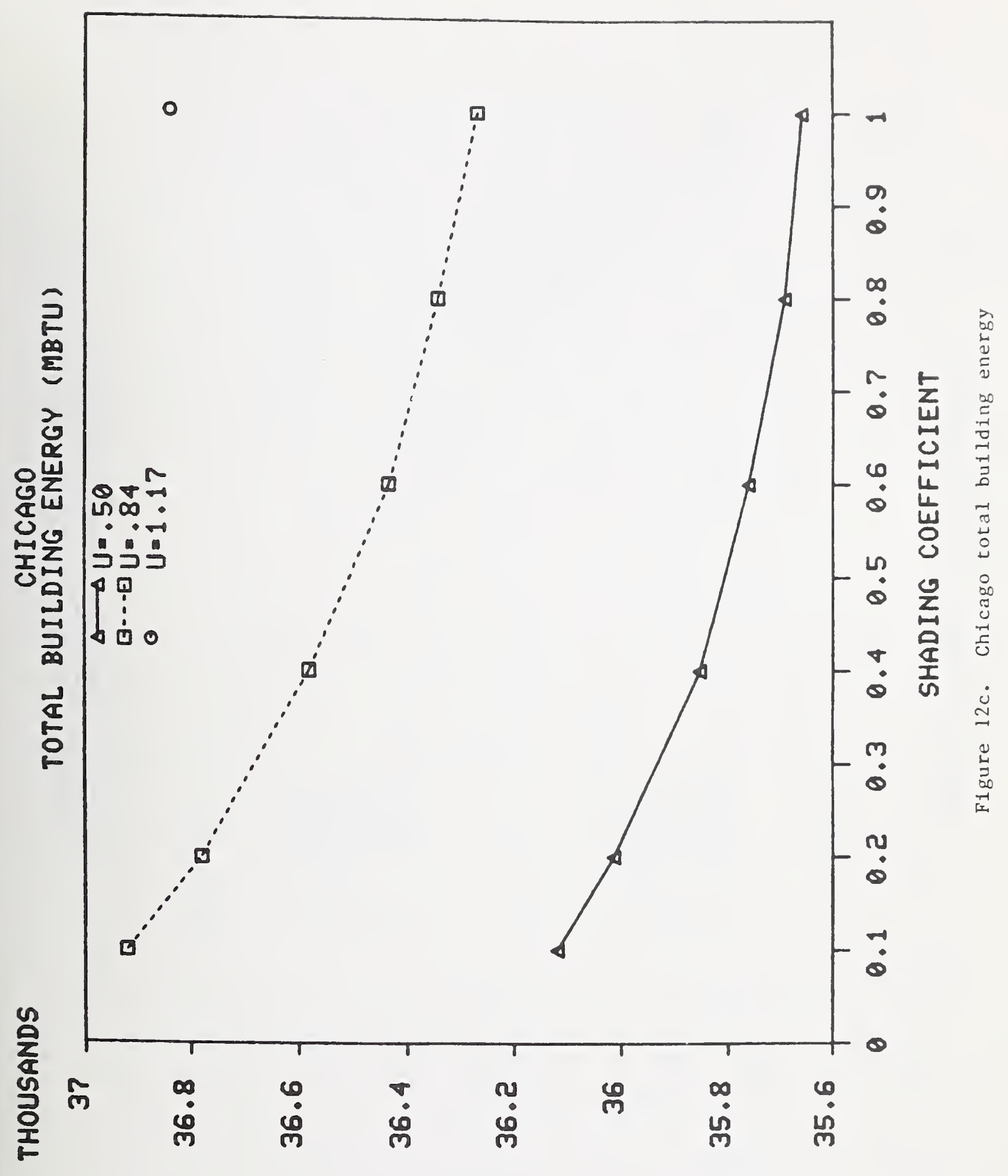

boras 


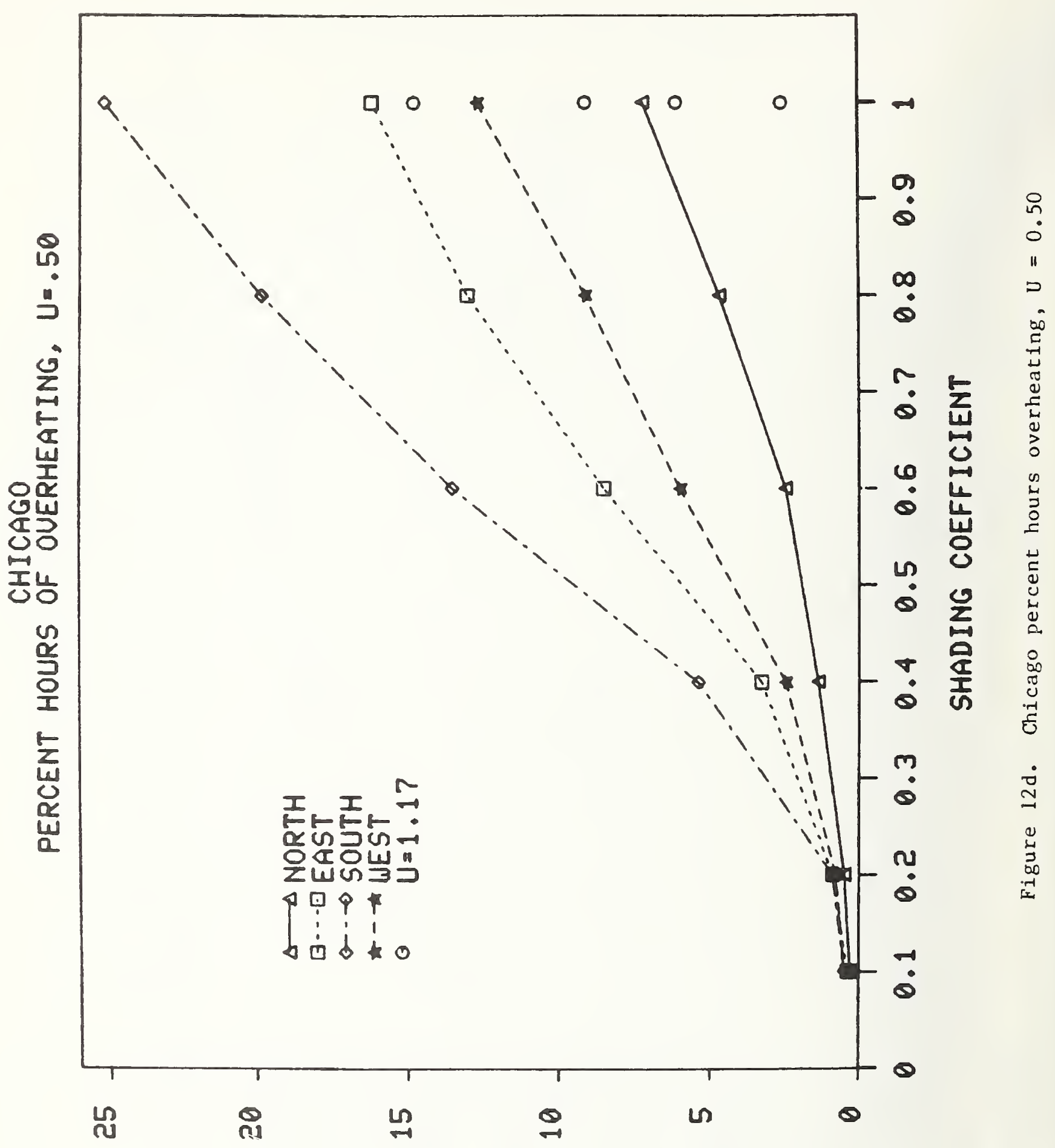

ロ оயUயZட 


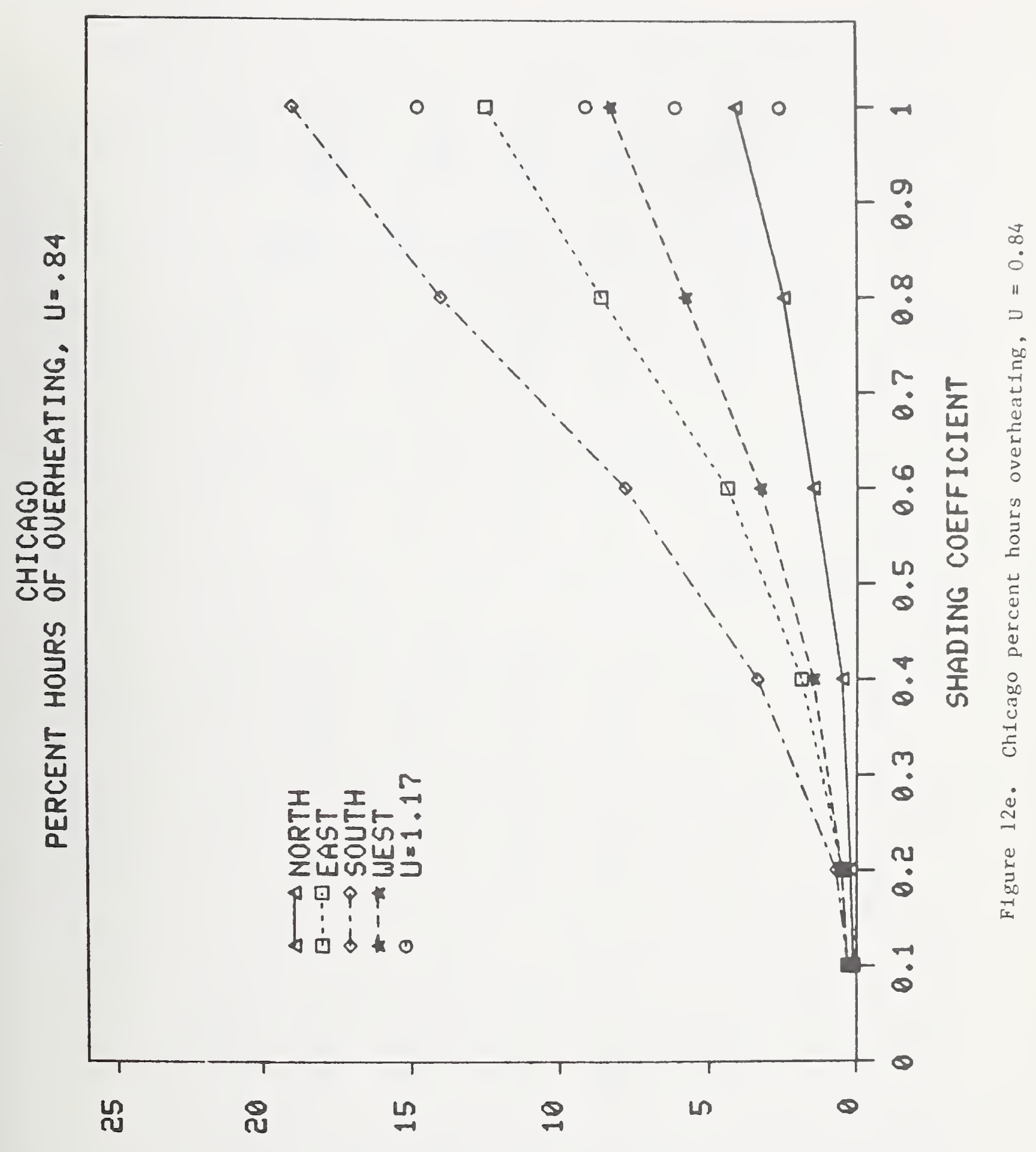

매லแZட 
Table 10a. Cost-effectiveness for Chicago $U=0.50$, Summer-only Cooling

FIRST YEAR ENERGY SAVINGS (DOLLARS) FOR SOLAR SCREENS $(U=0.50)$

\begin{tabular}{|c|c|c|c|c|c|c|}
\hline HEATING ENERGY & $S C=0.1$ & $S C=0.2$ & $S C=0.4$ & $S C=0.6$ & $\begin{array}{l}S C=0.8 \\
* \ldots *\end{array}$ & $S C=1.0$ \\
\hline $\begin{array}{l}\text { GAS } \\
\text { OIL } \\
\text { STEAM }\end{array}$ & $\begin{array}{l}12002 . \\
12843 \\
13162\end{array}$ & $\begin{array}{l}12152 \\
13683 \\
14264\end{array}$ & $\begin{array}{l}11787 . \\
14583 . \\
15643 .\end{array}$ & $\begin{array}{l}10592 . \\
14462 . \\
15930 .\end{array}$ & $\begin{array}{l}9158 . \\
14032 . \\
15830 .\end{array}$ & $\begin{array}{r}7425 . \\
13149 . \\
15320 .\end{array}$ \\
\hline
\end{tabular}

ASSUMPTIONS: $\quad$ ELECTRICITY COST $=\$ .068 / K W H$

HEATING FUEL COST $=\$ .022($ GAS), .038(OIL), .045(STEAM)/KWH

PAY-BACK PERIODS (YEARS) FOR SOLAR SCREENS (COST $=\$ 1.0 / S O . F T ., U=0.50$ )

$\begin{array}{crrrrrr}\text { HEATING ENERGY } & S C=0.1 & S C=0.2 & S C=0.4 & S C=0.6 & S C=0.8 & S C=1.0 \\ \text { GAS } & 4.0 & 4.0 & 4.0 & 4.0 & 5.0 & 6.0 \\ \text { OIL } & 4.0 & 4.0 & 4.0 & 4.0 & 4.0 & 4.0 \\ \text { STEAM } & 4.0 & 4.0 & 3.0 & 3.0 & 3.0 & 3.0\end{array}$

SAVINGS-TO-INVESTMENT RATIOS FOR SOLAR SCREENS (COST $=\$ 1.0 / 50 . F T ., U=0.50$ )

\begin{tabular}{|c|c|c|c|c|c|c|}
\hline HEATING ENERGY & $\begin{array}{l}S C=0.1 \\
\ldots \neq\end{array}$ & $\begin{array}{l}S C=0.2 \\
\cdots\end{array}$ & $\begin{array}{l}S C=0.4 \\
* * \cdots\end{array}$ & SC $=0.6$ & $\mathrm{SC}=0.8$ & $\begin{array}{l}S C=1.0 \\
* \ldots \ldots\end{array}$ \\
\hline $\begin{array}{l}\text { GAS } \\
\text { OIL } \\
\text { STEAM }\end{array}$ & $\begin{array}{l}2.4 \\
2.6 \\
2.7\end{array}$ & $\begin{array}{l}2.5 \\
2.7 \\
2.9\end{array}$ & $\begin{array}{l}2.5 \\
2.9 \\
3.2\end{array}$ & $\begin{array}{l}2.3 \\
2.8 \\
3.3\end{array}$ & $\begin{array}{l}2.0 \\
2.7 \\
3.3\end{array}$ & $\begin{array}{l}1.7 \\
2.5 \\
3.2\end{array}$ \\
\hline
\end{tabular}

10 YEAR PRESENT WORTH FACTOR $=9.6(G A S) .8 .0(O I L) .8 .8(S T E A M) .8 .4(E L E C)$ MATERIAL \& INSTALLATION COST $=\$ 42000$.

PAY-BACK PERIODS (YEARS) FOR SOLAR SCREENS (COST $=\$ 3.0 / S O$. FT.,$U=0.50$ )

$\begin{array}{crrrrrr}\text { HEATING ENERGY } & S C=0.1 & S C=0.2 & S C=0.4 & S C=0.6 & S C=0.8 & S C=1.0 \\ \text { GAS } & 14.0 & 13.0 & 14.0 & 15.0 & 18.0 & 22.0 \\ \text { CIL } & 13.0 & 12.0 & 11.0 & 11.0 & 12.0 & 13.0 \\ \text { STEAM } & 12.0 & 11.0 & 10.0 & 9.0 & 9.0 & 10.0\end{array}$

SAVINGS-TO-INVESTMENT RATIOS FOR SOLAR SCREENS (COST $=\$ 3.0 / S O . F T . . U=0.50$ )

\begin{tabular}{|c|c|c|c|c|c|c|}
\hline HEAT ING ENERGY & $\begin{array}{l}S C=0.1 \\
* \ldots * \cdots\end{array}$ & $S C=0.2$ & $S C=0.4$ & $\begin{array}{l}S C=0.6 \\
* * *\end{array}$ & $\begin{array}{l}S C=0.8 \\
\cdots\end{array}$ & $\begin{array}{l}S C=1.0 \\
* * *\end{array}$ \\
\hline $\begin{array}{l}\text { GAS } \\
\text { OIL } \\
\text { STEAM }\end{array}$ & $\begin{array}{l}1.3 \\
1.3 \\
1.4\end{array}$ & $\begin{array}{l}1.3 \\
1.5 \\
1.5\end{array}$ & $\begin{array}{l}1.3 \\
1.6 \\
1.7\end{array}$ & $\begin{array}{l}1.2 \\
1.6 \\
1.7\end{array}$ & $\begin{array}{l}1.1 \\
1.6 \\
1.7\end{array}$ & $\begin{array}{l}1.0 \\
1.5 \\
1.7\end{array}$ \\
\hline
\end{tabular}

20 YEAR PRESENT WORTH FACTOR = 16.2(GAS), 14.7(OIL), 13.9(STEAM). 12.9(ELEC) MATERIAL \& INSTALLATION COST $=\$ 126000$.

PAY-BACK PERIODS (YEARS) FOR SOLAR SCREENS (COST $=\$ 6.0 / S O . F T . . U=0.50$ )

$\begin{array}{cccrrrr}\text { HEATING ENERGY } & S C=0.1 & S C=0.2 & S C=0.4 & S C=0.6 & S C=0.8 & S C=1.0 \\ \text { GAS } & >30.0 & >30.0 & >30.0 & >30.0 & >30.0 & >30.0 \\ \text { OIL } & >30.0 & >30.0 & 29.0 & 27.0 & 27.0 & 27.0 \\ \text { STEAM } & >30.0 & >30.0 & >30.0 & 29.0 & 28.0 & 29.0\end{array}$

SAVINGS-TO-INVESTMENT RATIOS FOR SOLAR SCREENS (COST $=\$ 6.0 / 50$. FT. U U 0.50 )

$\begin{array}{crrrrrr}\text { HEATING ENERGY } & S C=0.1 & S C=0.2 & S C=0.4 & S C=0.6 & S C=0.8 & S C=1.0 \\ \text { GAS } & .8 & .8 & .8 & .8 & .7 & .6 \\ \text { OIL } & .8 & .9 & 1.0 & 1.1 & 1.1 & 1.1 \\ \text { STEAM } & .8 & .9 & 1.0 & 1.0 & 1.0 & 1.0\end{array}$

30 YEAR PRESENT WORTH FACTOR $=21.0($ GAS $), 21.1($ OIL), 16.7(STEAM). 15.4(ELEC) MATERIAL \& INSTALLATION COST $=\$ 252000$. 
Table 10b. Cost-effectiveness for Chicago $U=0.84$, Summer-only Cooling

FIRST YEAR ENERGY SAVINGS (DOLLARS) FOR SOLAR SCREENS (U=0.84)

$\begin{array}{ccccccr}\text { HEATING ENERGY } & \text { SC=0.1 } & \text { SC=0.2 } & \text { SC=0.4 } & \text { SC=0.6 } & \text { SC=0.8 } & S C=1.0 \\ \text { GAS } & 6137 . & 6675 . & 6747 . & 6184 . & 4959 . & 3627 . \\ \text { OIL } & 3386 . & 4730 . & 6176 . & 6856 . & 6706 . & 6374 . \\ \text { STEAM } & 2342 . & 3992 . & 5960 . & 7111 . & 7369 . & 7416 .\end{array}$

ASSUMPTIONS: ELECTRICITY COST $=\$ .068 / \mathrm{KWH}$

HEATING FUEL COST $=\$ .022$ (GAS), .038(OIL), .045(STEAM)/KWH

PAY-BACK PERIODS (YEARS) FOR SOLAR SCREENS (COST $=\$ 1.0 /$ SO. FT., U $=0.84$ )

$\begin{array}{crrrrrr}\text { HEATING ENERGY } & S C=0.1 & S C=0.2 & S C=0.4 & S C=0.6 & S C=0.8 & S C=1.0 \\ \text { GAS } & 9.0 & 8.0 & 7.0 & 8.0 & 10.0 & 13.0 \\ \text { OIL } & >30.0 & 11.0 & 8.0 & 7.0 & 8.0 & 8.0 \\ \text { STEAM } & >30.0 & 16.0 & 9.0 & 7.0 & 7.0 & 6.0\end{array}$

SAVINGS-TO-INVESTMENT RATIOS FOR SOLAR SCREENS (COST=\$1.0/SO. FT, U U 0.84 )

$\begin{array}{crrrrrr}\text { HEATING ENERGY } & S C=0.1 & S C=0.2 & S C=0.4 & S C=0.6 & S C=0.8 & S C=1.0 \\ \text { GAS } & 1.1 & 1.3 & 1.3 & 1.3 & 1.1 & .8 \\ \text { OIL } & .7 & 1.0 & 1.3 & 1.4 & 1.3 & 1.2 \\ \text { STEAM } & .4 & .8 & 1.2 & 1.4 & 1.5 & 1.6\end{array}$

10 YEAR PRESENT WORTH FACTOR = 9.6(GAS), 8.O(OIL), 8.8(STEAM), 8.4(ELEC) MATERIAL \& INSTALLATION COST $=\$ 42000$.

PAY-BACK PERIODS (YEARS) FOR SOLAR SCREENS (COST $=\$ 3.0 / S O$. FT., U=0.84)

$\begin{array}{crrrrrr}\text { HEATING ENERGY } & S C=0.1 & S C=0.2 & S C=0.4 & S C=0.6 & S C=0.8 & S C=1.0 \\ \text { GAS } & >30.0 & >30.0 & >30.0 & >30.0 & >30.0 & >30.0 \\ \text { OIL } & >30.0 & >30.0 & >30.0 & >30.0 & 30.0 & 28.0 \\ \text { STEAM } & >30.0 & >30.0 & >30.0 & >30.0 & >30.0 & >30.0\end{array}$

SAVINGS-TO-INVESTMENT RATIOS FOR SOLAR SCREENS (COST $=\$ 3.0 / S O$. FT., U $=0.84$ )

$\begin{array}{crrrrrr}\text { HEATING ENERGY } & S C=0.1 & S C=0.2 & S C=0.4 & S C=0.6 & S C=0.8 & S C=1.0 \\ \text { GAS } & .5 & .6 & .7 & .7 & .6 & .5 \\ \text { OIL } & .3 & .4 & .6 & .7 & .7 & .7 \\ \text { STEAM } & .2 & .4 & .6 & .7 & .8 & .8\end{array}$

20 YEAR PRESENT WORTH FACTOR $=16.2$ (GAS), 14.7(OIL), 13.9(STEAM), 12.9(ELEC) MATERIAL \& INSTALLATION COST $=\$ 126000$.

PAY.BACK PERIOOS (YEARS) FOR SOLAR SCREENS (COST $=\$ 6.0 / S Q$. FT., U $=0.84$ )

$\begin{array}{ccccccc}\text { HEATING ENERGY } & S C=0.1 & S C=0.2 & S C=0.4 & S C=0.6 & S C=0.8 & S C=1.0 \\ \text { GAS } & >30.0 & >30.0 & >30.0 & >30.0 & >30.0 & >30.0 \\ \text { OIL } & >30.0 & >30.0 & >30.0 & >30.0 & >30.0 & >30.0 \\ \text { STEAM } & >30.0 & >30.0 & >30.0 & >30.0 & >30.0 & >30.0\end{array}$

SAVINGS-TO-INVESTMENT RATIOS FOR SOLAR SCREENS (COST $=\$ 6.0 / S Q$. FT., U=0.84)

\begin{tabular}{|c|c|c|c|c|c|c|}
\hline HEATING ENERGY & $S C=0.1$ & $S C=0.2$ & $S C=0.4$ & $\begin{array}{l}S C=0.6 \\
\end{array}$ & $S C=0.8$ & $\begin{array}{l}S C=1.0 \\
* * 0\end{array}$ \\
\hline $\begin{array}{l}\text { GAS } \\
\text { OIL }\end{array}$ & .3 & $\begin{array}{l}.3 \\
.2\end{array}$ & .4 & .4 & .4 & 3 \\
\hline STEAM & .1 & .2 & .4 & .4 & .5 & .5 \\
\hline
\end{tabular}

30 YEAR PRESENT NORTH FACTOR $=21.0$ (GAS), 21.1(OIL), 16.7(STEAM), 15.4(ELEC) MATERIAL \& INSTALLATICN COST $=\$ 252000$. 
Table 10c. Cost-effectiveness for Chicago $U=0.50$, Al1-year Cooling

FIRST YEAR ENERGY SAVINGS (DOLLARS) FOR SOLAR SCREENS ( $U=\varnothing .5 \varnothing)$

\begin{tabular}{|c|c|c|c|c|c|c|}
\hline 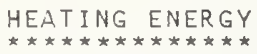 & $\begin{array}{l}\mathrm{SC}=\emptyset .1 \\
\star \star \star \star \star \star \star\end{array}$ & $\begin{array}{l}\mathrm{SC}=0.2 \\
\star \star \star \star \star \star \star \star *\end{array}$ & $\begin{array}{l}\mathrm{SC}=\emptyset .4 \\
\star \star \star \star \star \star \star\end{array}$ & 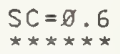 & $\begin{array}{l}\mathrm{SC}=\emptyset .8 \\
\star \star \star \star \star \star \star \star *\end{array}$ & $\begin{array}{l}\mathrm{SC}=1.0 \\
\star \star \star \star \star \star \star\end{array}$ \\
\hline $\begin{array}{l}\text { GAS } \\
\text { OIL } \\
\text { STEAM }\end{array}$ & $\begin{array}{l}19216 . \\
20799 . \\
21399 .\end{array}$ & $\begin{array}{l}17404 . \\
19418 . \\
20182 .\end{array}$ & $\begin{array}{l}13811 . \\
16713 . \\
17813 .\end{array}$ & $\begin{array}{l}16585 . \\
1435 \% . \\
15778 .\end{array}$ & $\begin{array}{r}7391 . \\
12043 . \\
13888 .\end{array}$ & $\begin{array}{r}3947 . \\
9434 \\
11515 .\end{array}$ \\
\hline
\end{tabular}

ASSUMPTIONS: $\quad$ ELECTRICITY COST $=\$ .068 / \mathrm{KWH}$

HEATING FUEL COST $=\$ . \varnothing 22$ (GAS), .

\begin{tabular}{|c|c|c|c|c|c|c|}
\hline 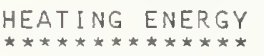 & $\begin{array}{l}\mathrm{SC}=\varnothing .1 \\
\star \star \star \star \star \star \star *\end{array}$ & $\begin{array}{l}S C=\emptyset .2 \\
\star \star \star \star \star \star\end{array}$ & $\begin{array}{l}\mathrm{SC}=\emptyset .4 \\
\star \star \star \star \star \star\end{array}$ & $\begin{array}{l}S C=\emptyset .6 \\
\star \star \star \star \star \star\end{array}$ & $\begin{array}{l}S C=\emptyset .8 \\
\star \star \star \star \star \star\end{array}$ & $\begin{array}{l}S C=1 . \varnothing \\
\star \star \star \star \star \star \star\end{array}$ \\
\hline $\begin{array}{c}\text { GAS } \\
\text { OIL } \\
\text { STEAM }\end{array}$ & $\begin{array}{l}3.0 \\
3.0 \\
3.0\end{array}$ & $\begin{array}{l}3.0 \\
3.0 \\
3.0\end{array}$ & $\begin{array}{l}4.0 \\
3.0 \\
3.0\end{array}$ & $\begin{array}{l}4.0 \\
4.0 \\
3.0\end{array}$ & $\begin{array}{l}6.0 \\
4.0 \\
4.0\end{array}$ & $\begin{array}{r}11.0 \\
6.0 \\
4.0\end{array}$ \\
\hline
\end{tabular}

SAVINGS-TO-INVESTMENT RATIOS FOR SOLAR SCREENS (COST $=\$ 1 . \varnothing / S O . F T ., U=\varnothing .5 \varnothing)$

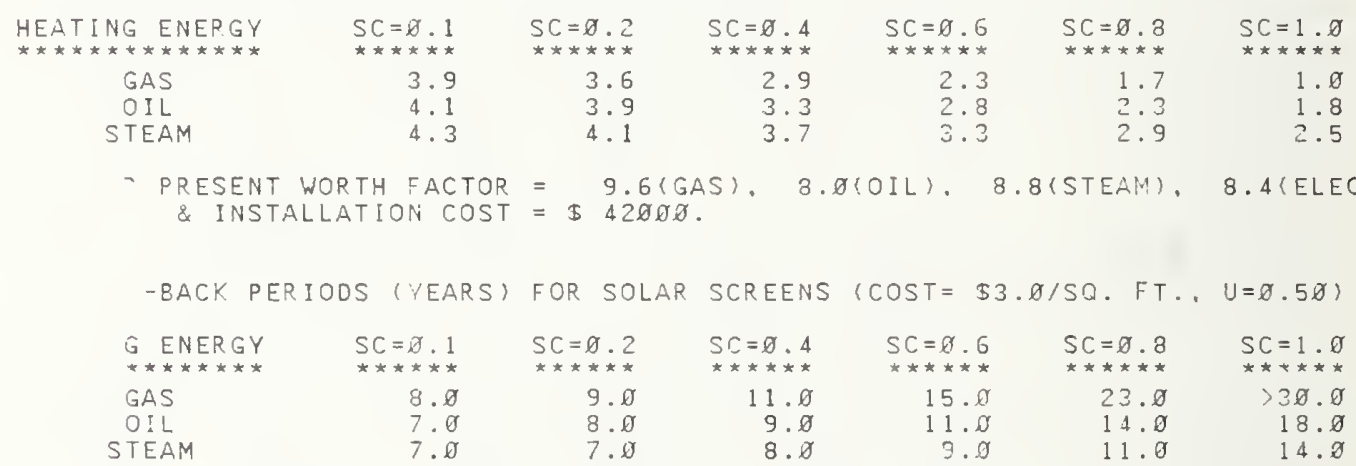

IINGS-TO-INVESTMENT RATIOS FOR SOLAR SCREENS (COST $=\$ 3 . \varnothing / S O . \quad F T . \quad U=\varnothing .5 \varnothing$ )

\begin{tabular}{|c|c|c|c|c|c|c|}
\hline$\Sigma A T$ & $S C=\varnothing .1$ & $S C=\varnothing .2$ & $S C=\not .4$ & $S C=\triangleright .6$ & $S C=\not .8$ & $S C=1 . \varnothing$ \\
\hline GAS & 2. & 1.9 & 1.5 & 1.2 & .9 & .6 \\
\hline STEAM & $\begin{array}{l}2.2 \\
2.2\end{array}$ & $\begin{array}{l}2.1 \\
2.1\end{array}$ & $\begin{array}{l}1.8 \\
1.9\end{array}$ & $\begin{array}{l}1.6 \\
1.7\end{array}$ & $\begin{array}{l}1.4 \\
1.5\end{array}$ & $\begin{array}{l}1.1 \\
1.3\end{array}$ \\
\hline
\end{tabular}

20 YEAR PRESENT WORTH FACTOR $=16.2$ (GAS), $14.7(0 \mathrm{IL}), 13.9$ (STFAM), 12.9 (ELEC) MATERIAL \& INSTALLATION COST $=\$ 126000$.

PAY-BACK PERIODS (YEARS) FOR SOLAR SCREENS (COST $=\$ 6 . \not / S O . F T, y=\varnothing .5 \varnothing$ )

\begin{tabular}{|c|c|c|c|c|c|c|}
\hline 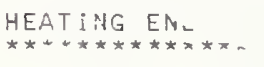 & $\begin{array}{l}\text { SC }=\varnothing, 1 \\
\star \star \star \star \star \star\end{array}$ & $\begin{array}{l}S C=\emptyset .2 \\
* \star \star \star * *\end{array}$ & $\begin{array}{l}S C=\varnothing .1 \\
\star \star \star \star \star \star *\end{array}$ & $\begin{array}{l}S C=\not y .6 \\
* \star \star \star \star \star *\end{array}$ & $\begin{array}{l}S C=\emptyset .3 \\
\star \star \star \star \star \star \star *\end{array}$ & $\begin{array}{l}S C=1 . \varnothing \\
* * * * *\end{array}$ \\
\hline & $\begin{array}{l}20.0 \\
18.0 \\
17.0\end{array}$ & $\begin{array}{l}24.0 \\
20.0 \\
18.0\end{array}$ & $\begin{array}{r}>30.0 \\
24.0 \\
23.9\end{array}$ & $\begin{array}{r}>3.0 .0 \\
28.0 \\
29.8\end{array}$ & $\begin{array}{l}>30.0 \\
>38.0 \\
>30.0\end{array}$ & $\begin{array}{l}>30.8 \\
>3 \varnothing . \varnothing \\
>3 \varnothing . \varnothing\end{array}$ \\
\hline
\end{tabular}

$17.0 \quad 18.0 \quad 23.9$

SAVINGS-TO-INVESTMENT RATIOS FOR SOLAR. SCREENS (COST $=\$ 6 . \varnothing / S O . \quad F T, \quad U=\emptyset .5 \varnothing)$

\begin{tabular}{|c|c|c|c|c|c|c|}
\hline 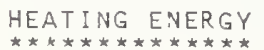 & $\begin{array}{l}S C=\varnothing, 1 \\
\star * * \pm\end{array}$ & $S C=\varnothing .2$ & $S C=\varnothing .4$ & $S C=\varnothing .6$ & $s c=\varnothing .8$ & $S C=1 . \varnothing$ \\
\hline $\begin{array}{l}\text { GAS } \\
\text { OIL } \\
\text { STEAM }\end{array}$ & $\begin{array}{l}1.2 \\
1.4 \\
1.3\end{array}$ & $\begin{array}{l}1.1 \\
1.3 \\
1.3\end{array}$ & $\begin{array}{r}\cdot 9 \\
1.2 \\
1.1\end{array}$ & $\begin{array}{r}.8 \\
1.1 \\
1.0\end{array}$ & $\begin{array}{r}.6 \\
1.0 \\
.9\end{array}$ & $\begin{array}{r}.4 \\
.9 \\
.8\end{array}$ \\
\hline
\end{tabular}

30 YEAR PRESENT WORTH FACTOR = 21. $($ GAS), 21.1 (OIL), 16.7(STEAM), 15.4 (ELEC) MATERIAL \& INSTALLATION COST $=\$ 252000$. 
Table 10d. Cost-effectiveness for Chicago $U=0.84$, All-year Cooling

FIRST YEAR ENERGY SAVINGS (DOLLARS) FOR SOLAR SCREENS $(U=\$ 8.84)$

\begin{tabular}{|c|c|c|c|c|c|c|}
\hline $\begin{array}{l}\text { HEAT ING ENERGY } \\
\star \star \star \star \star \star \star * * * \star * \star * \star * *\end{array}$ & $\begin{array}{l}\mathrm{SC}=\varnothing .1 \\
\star \star \star \star \star \star \star\end{array}$ & 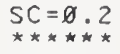 & $\begin{array}{l}S C=\varnothing \cdot 4 \\
\star \star \star \star \star \star \star\end{array}$ & $\begin{array}{l}\mathrm{SC}=\varnothing .6 \\
\star \star \star \star \star \star\end{array}$ & $\begin{array}{l}\mathrm{SC}=\varnothing .8 \\
\star \star \star \star \star \star \star \star\end{array}$ & $\begin{array}{l}S C=I . \varnothing \\
* * * * * *\end{array}$ \\
\hline $\begin{array}{c}\text { GAS } \\
\text { OIL } \\
\text { STEAM }\end{array}$ & $\begin{array}{l}13398 . \\
11384 . \\
10620 .\end{array}$ & $\begin{array}{l}12647 . \\
11112 . \\
19530 .\end{array}$ & $\begin{array}{l}9478 . \\
8999 . \\
8817 .\end{array}$ & $\begin{array}{l}7139 . \\
7739 . \\
7966 .\end{array}$ & $\begin{array}{l}4800 . \\
6479 . \\
7115 .\end{array}$ & $\begin{array}{l}3528 . \\
6196 . \\
7199 .\end{array}$ \\
\hline
\end{tabular}

ASSUMPTIONS: $\quad$ ELECTRICITY COST $=\$ .068 / \mathrm{KWH}$

HEATING FUEL COST $=\$ .022(\mathrm{GAS}), .038(O I L), .045(S T E A M) / K W H$

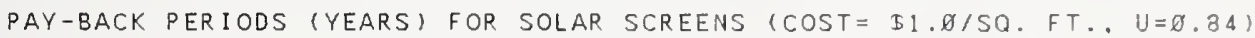

\begin{tabular}{|c|c|c|c|c|c|c|}
\hline 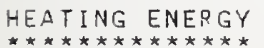 & $S C=\varnothing .1$ & $S C=\emptyset .2$ & $S C=\varnothing .4$ & $S C=\emptyset .6$ & $S C=\not .8$ & $S C=1 . \varnothing$ \\
\hline $\begin{array}{l}\text { GAS } \\
\text { OIL }\end{array}$ & $\begin{array}{l}4 . \varnothing \\
4 . \varnothing\end{array}$ & $\begin{array}{r}4 . \varnothing \\
4 . \varnothing\end{array}$ & $\begin{array}{r}5.0 \\
5.0\end{array}$ & $\begin{array}{r}7.0 \\
6 . \varnothing\end{array}$ & $\begin{array}{r}10.0 \\
8 . \varnothing\end{array}$ & $\begin{array}{r}14.0 \\
9.0\end{array}$ \\
\hline STEAM & 5.0 & 5.0 & 6.0 & 6.8 & 7.8 & 7.0 \\
\hline
\end{tabular}

SAVINGS-TO-INVESTMENT RATIOS FOR SOLAR SCREENS (COST $=\$ 1 . \varnothing / S O . F T . \quad U=\not .84$ )

\begin{tabular}{|c|c|c|c|c|c|c|}
\hline 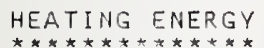 & $S C=\varnothing .1$ & $S C=0.2$ & $S C=\varnothing .4$ & $S C=\varnothing .6$ & $S C=\Omega .8$ & $S C=1 . \ell$ \\
\hline$* * * * * * * * * * * * * *$ & *** & $\begin{array}{r}\star * * \star * * \star \\
2 \pi\end{array}$ & $* * * * * *$ & $\star * * * \star * *$ & $* * * *$ & * * \\
\hline $\begin{array}{l}\text { GAS } \\
\text { OIL }\end{array}$ & $\begin{array}{l}2.6 \\
2.3\end{array}$ & $\begin{array}{l}2.5 \\
2.3\end{array}$ & $\begin{array}{l}1.9 \\
1.8\end{array}$ & 1.5 & 1.3 & 1. \\
\hline STEAM & 2.1 & 2.1 & 1.8 & 1.6 & 1.5 & 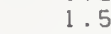 \\
\hline
\end{tabular}

10 YEAP. PRESENT WORTH FACTOR $=9,6$ (GAS), 8.0(OIL), 8.8(STEAM), 8.4'ELEC) MATERIAL \& INSTALLATION COST $=\$ 42000$.

PAY-BACK PERIODS (YEARS) FOP, SOLAR SCREENS (COST $=\$ 3 . \not / S O . F T, U=\not .34$ )

\begin{tabular}{|c|c|c|c|c|c|c|}
\hline HEATING ENERGY & $S C=\varnothing .1$ & $S C=\varnothing .2$ & $S C=\varnothing .4$ & $S C=\not \partial . \sigma$ & $S C=0.8$ & $S C=1 . \varnothing$ \\
\hline 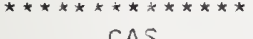 & & & $\star \star \star * \star * \star *$ & 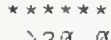 & $\star \star * \star * * *$ & \\
\hline $\begin{array}{l}\text { GAS } \\
\text { OIL }\end{array}$ & $\begin{array}{l}13.0 \\
16.0\end{array}$ & 17.00 & 27.0 & $\begin{array}{r}30.0 \\
30.0 \\
38.0\end{array}$ & $\begin{array}{r}30.0 \\
30.0\end{array}$ & 29.0 \\
\hline
\end{tabular}

SAVIIIGS-TO-INVESTMENT P.ATIOS FOR SOLAR. SCREENS (COST= B3.Ø/SQ. FT. U U 0.24 )

\begin{tabular}{|c|c|c|c|c|c|c|}
\hline HEATING ENERGV & $S C=X .1$ & $S C=\not 0.2$ & $S C=\varnothing .4$ & $S C=\not 1.6$ & $S C=\not \partial .8$ & $\begin{array}{l}S C=1.0 \\
* * * * * * x\end{array}$ \\
\hline 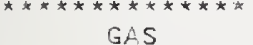 & $k * *$ & $\begin{array}{r}* * * * * * \\
1.2\end{array}$ & $\begin{array}{r}\star * * * * * \\
1 . \not ु\end{array}$ & *** &.$* *$ & $k$ * \\
\hline $0 ! 1$ & 1.1 & 1.1 & .9 & .8 & .7 & 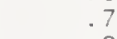 \\
\hline STEAM & $1 . \varnothing$ & $1 . \varnothing$ & .9 & .8 & .3 & .8 \\
\hline
\end{tabular}

29 7EAR PRESENT WORTH FACTOR = I6.2(GAS), 14.7(OIL), 13.9(STEAM), 12.9:ELEC) MATEP.SAL \& INSTALLATION COST $=\$ 126000$.

PAY-BACK PERIODS (YEARS) FOR SOLAR SCREENS (COST $=56.9 / 50 . \quad F T \ldots(I=0.34$ )

\begin{tabular}{|c|c|c|c|c|c|c|}
\hline 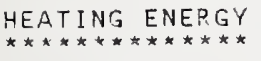 & $\begin{array}{l}S C=\emptyset . I \\
\star * \star \star \star \star *\end{array}$ & $\begin{array}{l}\mathrm{SC}=\varnothing .2 \\
\star \star \star \star \star \star \star *\end{array}$ & $\begin{array}{l}S C=\varnothing .4 \\
\star \star \star \star \star * *\end{array}$ & $\begin{array}{l}\mathrm{SC}=\varnothing .6 \\
\star \star \star \star \star *\end{array}$ & $\begin{array}{l}S C=\varnothing .8 \\
* * * * *\end{array}$ & $\begin{array}{l}S C=1 . \varnothing \\
* * *+*\end{array}$ \\
\hline $\begin{array}{l}\text { GAS } \\
\text { OIL }\end{array}$ & $\begin{array}{l}>30.0 \\
>3 \% .0 \\
>30.0\end{array}$ & $\begin{array}{l}>30.0 \\
>30.0 \\
>30.0\end{array}$ & $\begin{array}{l}>30.0 \\
>30.0 \\
>30 . \varnothing\end{array}$ & $\begin{array}{l}>30.0 \\
>30.0 \\
>30.0\end{array}$ & $\begin{array}{l}>3 \theta .0 \\
>30.0 \\
>30.0\end{array}$ & $\begin{array}{l}130.0 \\
30.8 \\
30.0\end{array}$ \\
\hline
\end{tabular}

SAVINSS-TO-INVESTMENT RATIOS FOR SOLAR SCREENS $(C O S T=\$ 6.0 / S Q . F T . U=\varnothing .84)$

\begin{tabular}{|c|c|c|c|c|c|c|}
\hline 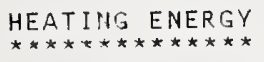 & $\begin{array}{l}S C=\varnothing \cdot 1 \\
\star \star \star \star \star \star * *\end{array}$ & $\begin{array}{l}\mathrm{SC}=\varnothing .2 \\
\star \star \star \star \star * *\end{array}$ & $\begin{array}{l}S C=\varnothing ; 4 \\
* * * * * *\end{array}$ & $\begin{array}{l}\mathrm{SC}=\varnothing .6 \\
* \star \star \star * *\end{array}$ & $\begin{array}{l}\mathrm{SC}=0.8 \\
\star \star \star \star * * *\end{array}$ & $\begin{array}{l}S C=1.8 \\
* * * * *\end{array}$ \\
\hline $\begin{array}{l}\text { GAS } \\
\text { OIL } \\
\text { STEAM }\end{array}$ & $\begin{array}{l}.8 \\
.6 \\
.6\end{array}$ & $\begin{array}{l}.7 \\
.6 \\
.6\end{array}$ & $\begin{array}{l}.6 \\
.5 \\
.5\end{array}$ & $\begin{array}{l}.5 \\
.5 \\
.5\end{array}$ & $\begin{array}{l}.3 \\
.5 \\
.5\end{array}$ & $\begin{array}{l}.3 \\
.5 \\
.5\end{array}$ \\
\hline
\end{tabular}

3. YEAR PRESENT WORTH FACTOR $=21.0($ GAS). 21. I (OIL), 16.7(STEAM). 15. A(ELEC) MATER IAL \& INSTALLATION COST $=\$ 252000$. 


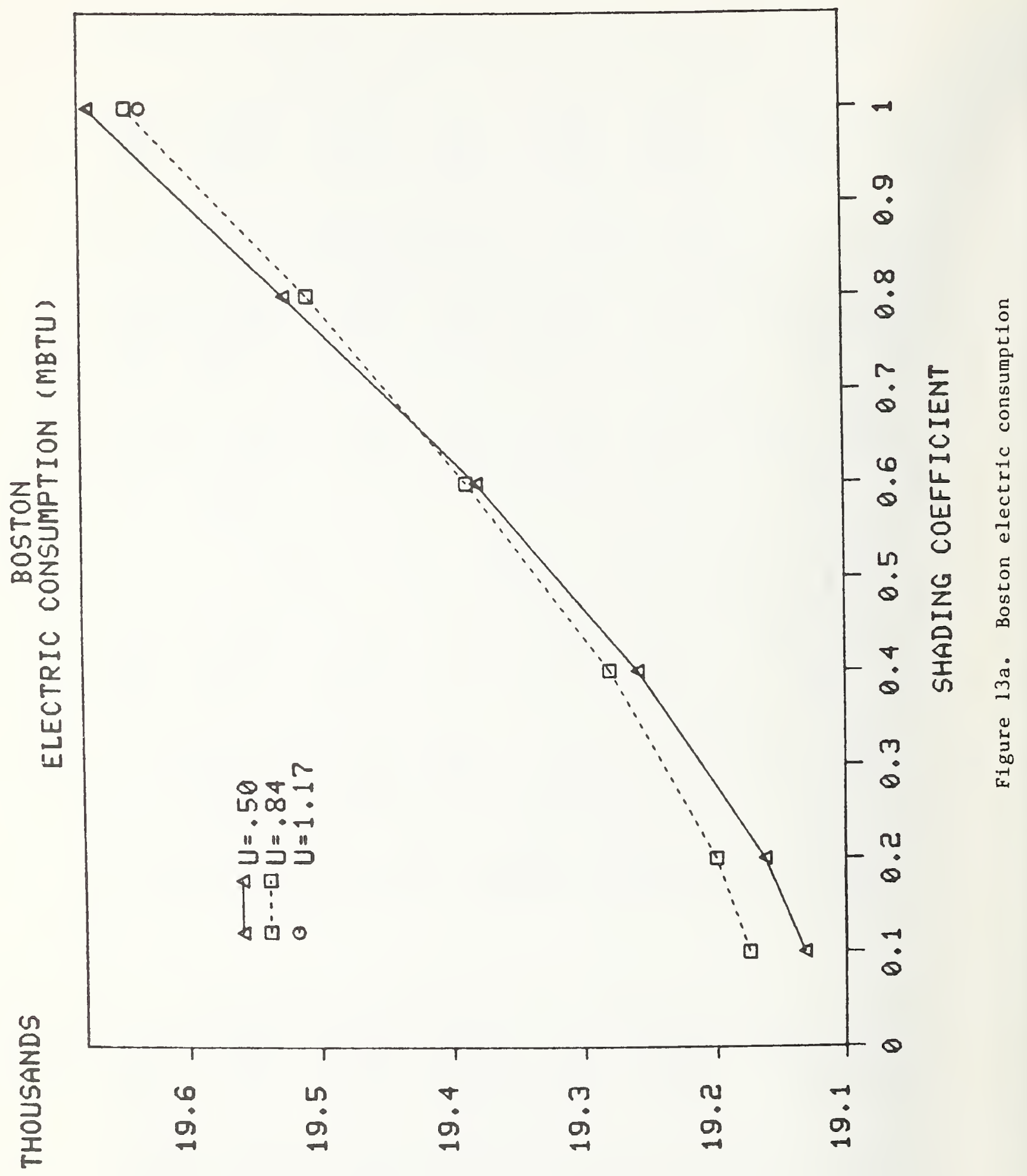

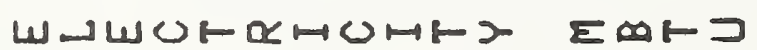




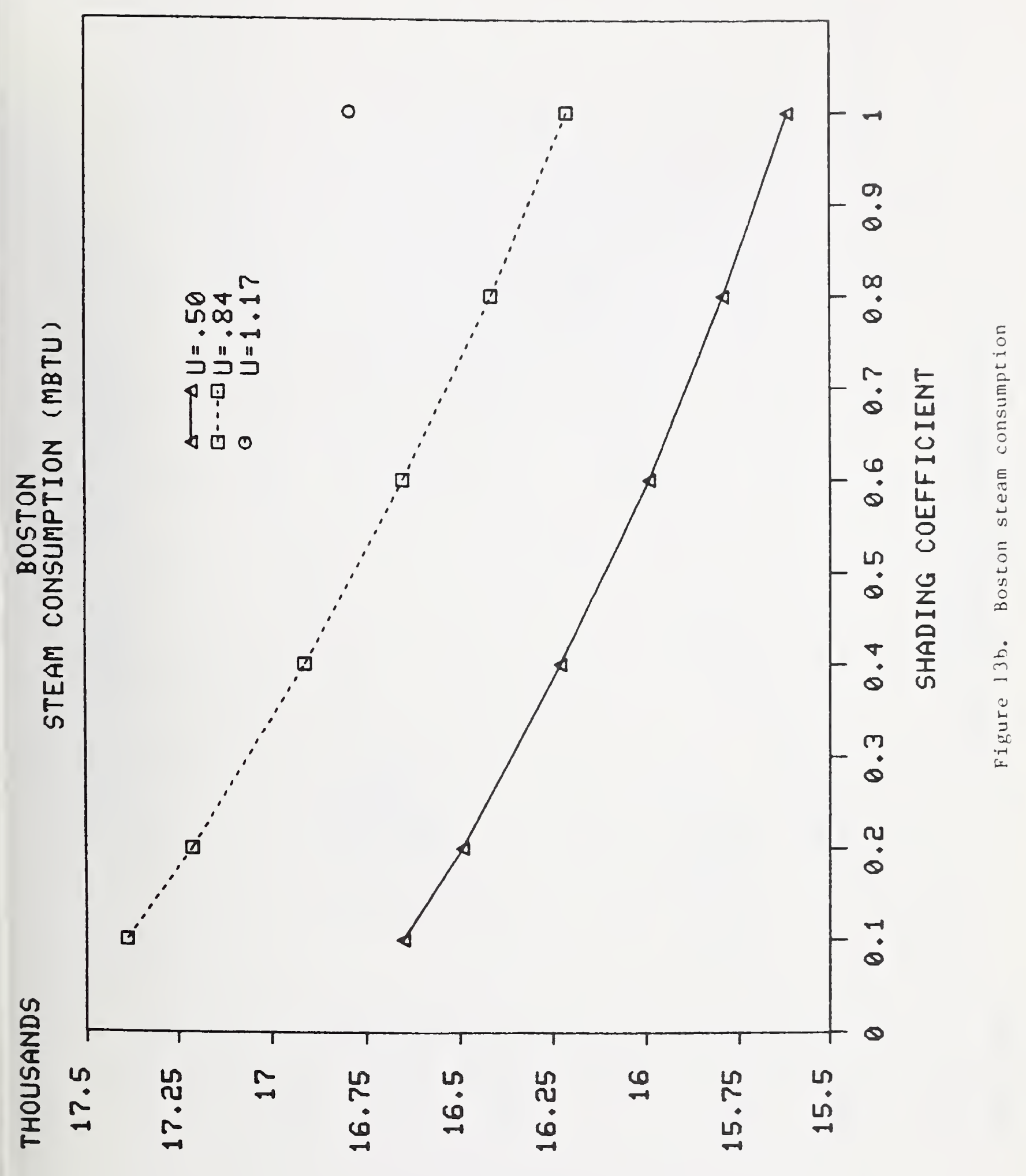

GLWबE 


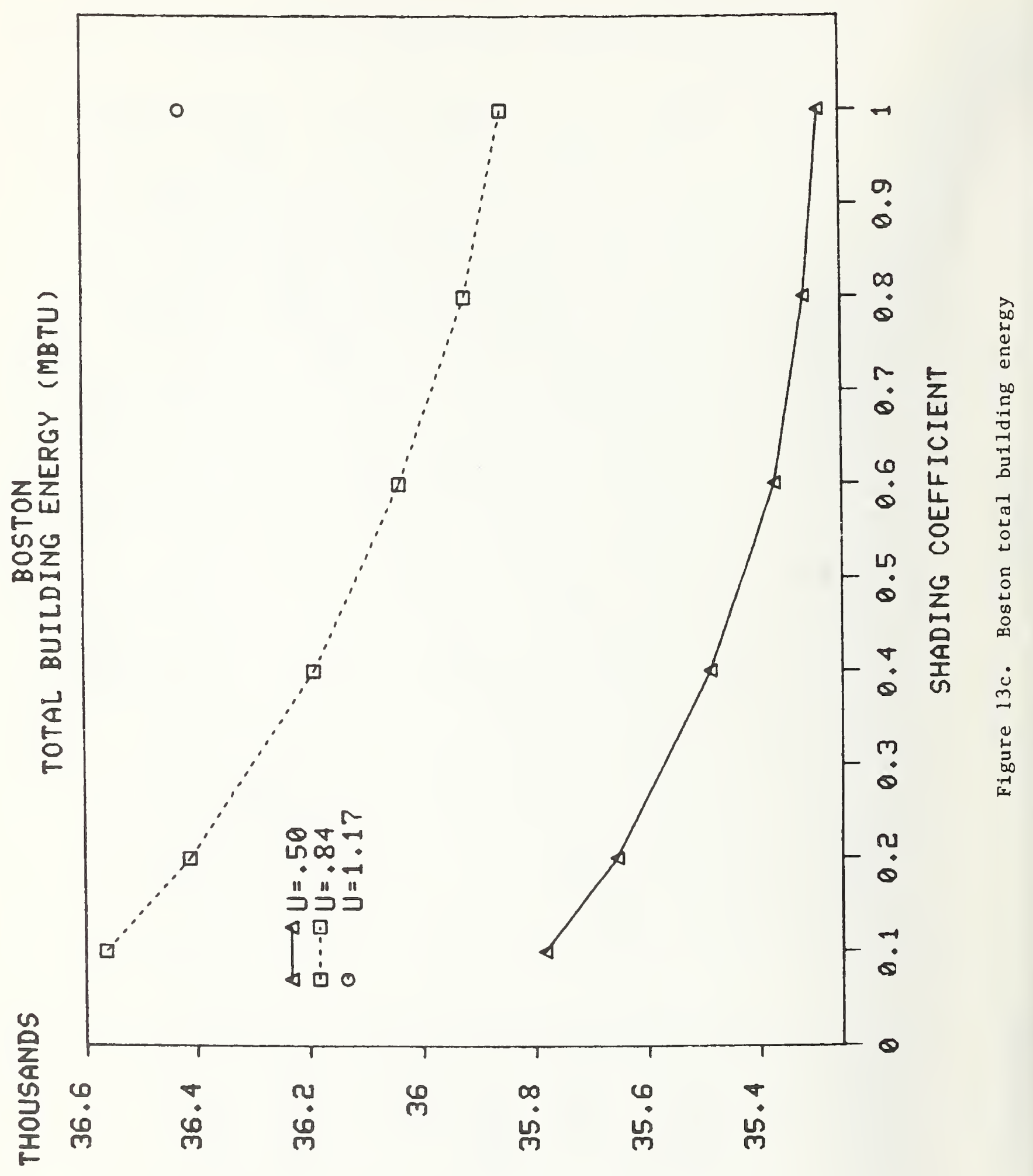

tot 


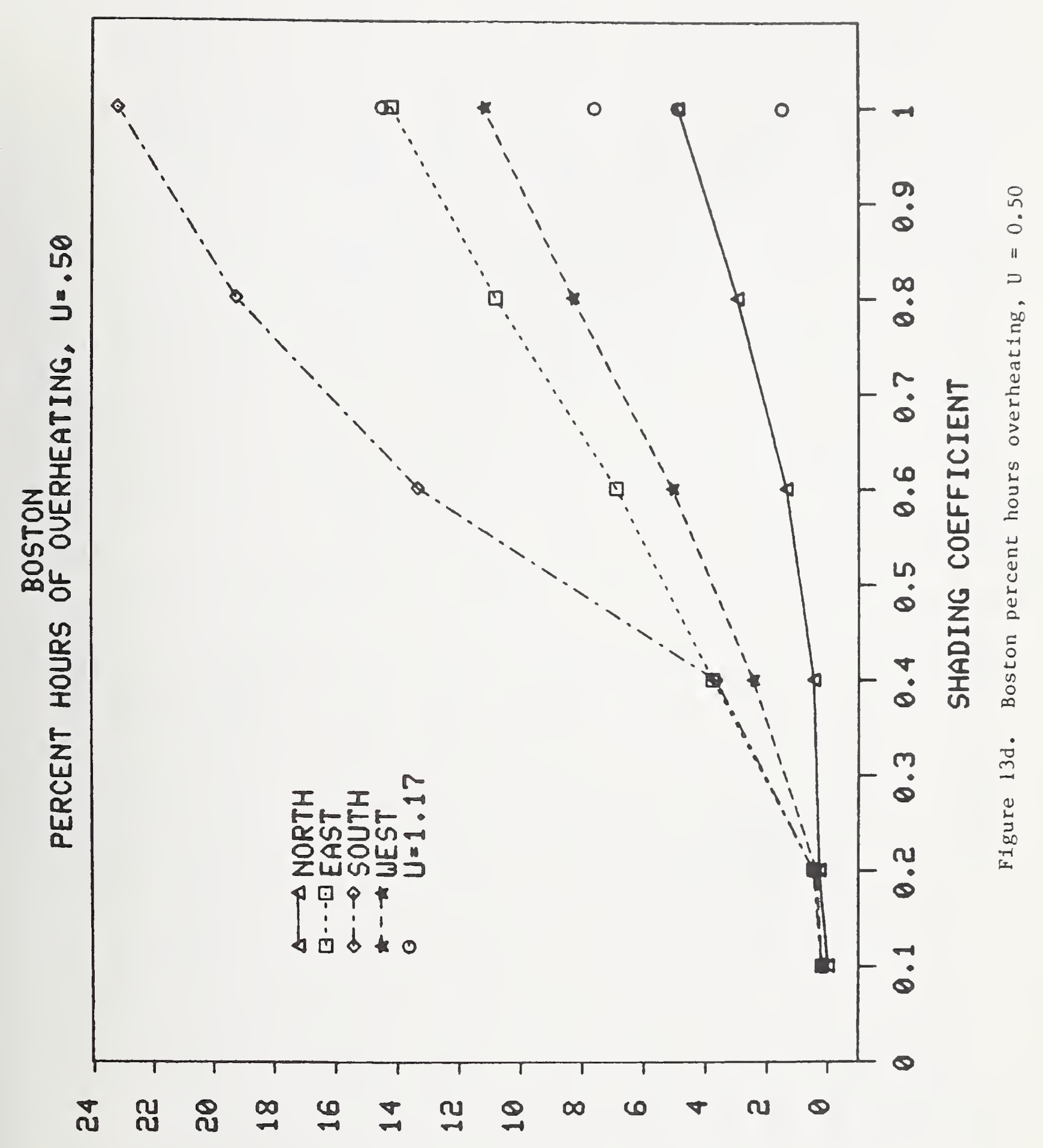

눈ㄴ 


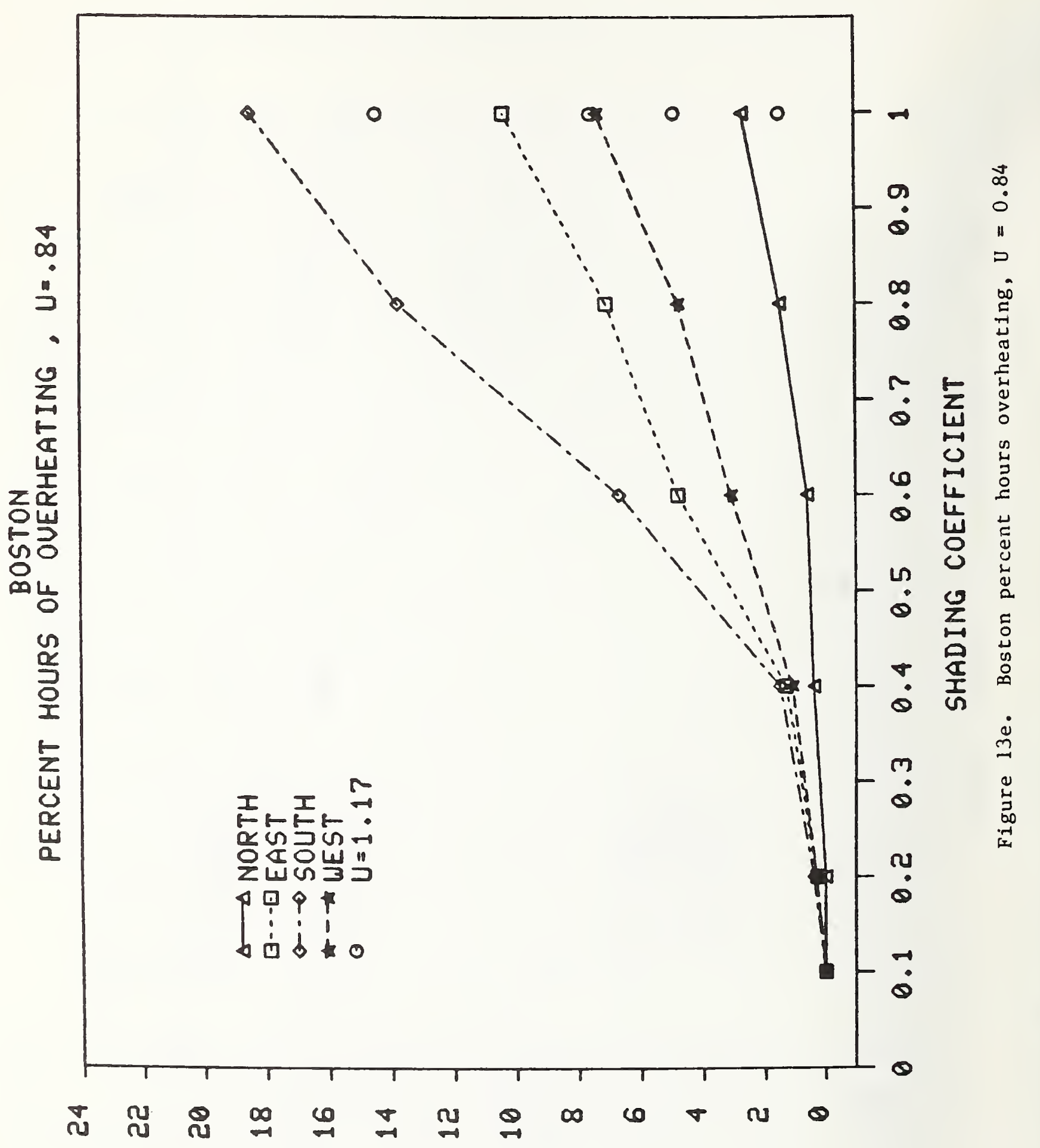

aw $\alpha \circlearrowleft \omega Z \leftarrow$ 
Table 11a. Cost-effectiveness for Boston $U=0.50$, Sumer-only Cooling

FIRST YEAR ENERGY SAVINGS (DOLLARS) FOR SOLAR SCREENS (U=0.50)

$\begin{array}{clllllr}\text { HEATING ENERGY } & S C=0.1 & S C=0.2 & S C=0.4 & S C=0.6 & S C=0.8 & S C=1.0 \\ \text { GAS } & 13943 . & 14497 . & 14255 . & 13170 . & 11180 . & 8888 . \\ \text { OIL } & 14191 . & 15028 . & 15253 . & 14591 . & 12953 . & 10976 . \\ \text { STEAM } & 14711 . & 16138 . & 17337 . & 17558 . & 16657 .\end{array}$

ASSUMPTIONS: $\quad$ ELECTRICITY COST $=\$ .087 / \mathrm{KWH}$

HEATING FUEL COST $=\$ .029$ (GAS),.035(OIL),.047(STEAM)/KWH

PAY-BACK PERIODS (YEARS) FOR SOLAR SCREENS (COST $=\$ 1.0 / S O$. FT. U U $=0.50$ )

$\begin{array}{crrrrrr}\text { HEATING ENERGY } & S C=0.1 & S C=0.2 & S C=0.4 & S C=0.6 & S C=0.8 & S C=1.0 \\ \text { GAS } & 4.0 & 3.0 & 3.0 & 4.0 & 4.0 & 5.0 \\ \text { OIL } & 4.0 & 3.0 & 3.0 & 4.0 & 4.0 & 5.0 \\ \text { STEAM } & 3.0 & 3.0 & 3.0 & 3.0 & 3.0 & 3.0\end{array}$

SAVINGS-TO-INVESTMENT RATIOS FOR SOLAR SCREENS (COST= \$1.0/SO. FT., U=0.50)

$\begin{array}{crrrrrr}\text { HEATING ENERGY } & \text { SC=0.1 } & \text { SC=0.2 } & \text { SC=0.4 } & \text { SC=0.6 } & \text { SC=0.8 } & S C=1.0 \\ \text { GAS } & 2.7 & 2.9 & 2.9 & 2.8 & 2.4 & 2.0 \\ \text { OIL } & 2.7 & 2.9 & 2.9 & 2.8 & 2.5 & 2.1 \\ \text { STEAM } & 2.8 & 3.1 & 3.3 & 3.4 & 3.2 & 3.0\end{array}$

10 YEAR PRESENT WORTH FACTOR = 9.5(GAS). 8.0(OI1.). 8.1(STEAM), 8.1(ELEC) MATERIAL \& INSTALLATION COST $=\$ 42000$.

PAY-BACK PERIODS (YEARS) FOR SOLAR SCREENS (COST $=\$ 3.0 / S O$. FT. U U $=0.50$ )

$\begin{array}{crrrrrr}\text { HEATING ENERGY } & S C=0.1 & S C=0.2 & S C=0.4 & S C=0.6 & S C=0.8 & S C=1.0 \\ \text { GAS } & 12.0 & 11.0 & 11.0 & 12.0 & 14.0 & 17.0 \\ \text { OIL } & 12.0 & 11.0 & 11.0 & 12.0 & 13.0 & 16.0 \\ \text { STEAM } & 11.0 & 10.0 & 9.0 & 9.0 & 9.0 & 11.0\end{array}$

SAVINGS-TO-INVESTMENT RATIOS FOR SOLAR SCREENS (COST= $\$ 3.0 / 50$. FT., U $=0.50$ )

$\begin{array}{crrrrrr}\text { HEATING ENERGY } & S C=0.1 & S C=0.2 & S C=0.4 & S C=0.6 & S C=0.8 & S C=1.0 \\ \text { GAS } & 1.3 & 1.4 & 1.4 & 1.4 & 1.3 & 1.1 \\ \text { OIL } & 1.3 & 1.4 & 1.5 & 1.5 & 1.4 & 1.3 \\ \text { STEAM } & 1.3 & 1.5 & 1.6 & 1.7 & 1.6 & 1.5\end{array}$

20 YEAR PRESENT WORTH FACTOR $=15.6($ GAS), 14.6(OIL), 12.2(STEAM), 11.4(ELEC) MATERIAL \& INSTALLATION COST $=\$ 126000$.

PAY-BACK PERIODS (YEARS) FOR SOLAR SCREENS (COST $=\$ 6.0 / S O$. FT., U=0.50)

$\begin{array}{ccccccc}\text { HEATING ENERGY } & S C=0.1 & S C=0.2 & S C=0.4 & S C=0.6 & S C=0.8 & S C=1.0 \\ \text { GAS } & >30.0 & >30.0 & >30.0 & >30.0 & >30.0 & >30.0 \\ \text { OIL } & >30.0 & >30.0 & >30.0 & 30.0 & >30.0 & >30.0 \\ \text { STEAM } & >30.0 & >30.0 & >30.0 & >30.0 & >30.0 & >30.0\end{array}$

SAVINGS-TO-INVESTMENT RATIOS FOR SOLAR SCREENS (COST=\$6.0/SO. FT., U=0.50)

$\begin{array}{crrrrrr}\text { HEATING ENERGY } & S C=0.1 & S C=0.2 & S C=0.4 & S C=0.6 & S C=0.8 & S C=1.0 \\ \text { GAS } & .7 & .8 & .9 & .9 & .9 & .7 \\ \text { OIL } & .8 & .9 & 1.0 & 1.0 & 1.0 & .9 \\ \text { STEAM } & .8 & .8 & .9 & 1.0 & .9 & .9\end{array}$

30 YEAR PRESENT WORTH FACTOR $=19.8$ (GAS), 20.9(OIL), 14.7(STEAM), 12.7 (ELEC) MATERIAL \& INSTALLATION COST $=\$ 252000$. 
Table 11b. Cost-effectiveness for Boston $U=0.84$, Summer-only Cooling

FIRST YEAR ENERGY SAVINGS (DOLLARS) FOR SOLAR SCREENS $(U=0.84$ )

\begin{tabular}{|c|c|c|c|c|c|c|}
\hline $\begin{array}{l}\text { HEATING ENERGY } \\
\end{array}$ & $\begin{array}{l}S C=0.1 \\
* * * * *\end{array}$ & $\begin{array}{l}S C=0.2 \\
* * * * \ldots\end{array}$ & $\begin{array}{l}S C=0.4 \\
* * * * * *\end{array}$ & $S C=0.6$ & $S C=0.8$ & $S C=1.0$ \\
\hline $\begin{array}{l}\text { GAS } \\
\text { OIL } \\
\text { STEAM }\end{array}$ & $\begin{array}{l}6622 . \\
5560 . \\
3341 .\end{array}$ & $\begin{array}{l}7487 . \\
6742 . \\
5186 .\end{array}$ & $\begin{array}{l}7971 . \\
7758 . \\
7315 .\end{array}$ & $\begin{array}{l}7411 . \\
7659 . \\
8178 .\end{array}$ & $\begin{array}{l}6369 . \\
7037 . \\
8432 .\end{array}$ & $\begin{array}{l}4600 . \\
5629 . \\
7778 .\end{array}$ \\
\hline ASSUMPTIONS: & $\begin{array}{l}\text { ELECTRICITY } \\
\text { HEATING FUEL }\end{array}$ & $\begin{array}{l}\cos T=\$ \\
\cos T=\$\end{array}$ & $\begin{array}{l}.087 / \mathrm{KWH} \\
.029 \text { (GAS) }\end{array}$ & . . .035(OIL). & .047 STE & $E A M) / K W H$ \\
\hline PAY-BACK PER & IODS (YEARS) & FOR SOLAR & SCREENS & $(\cos T=\$ 1.0 /$ & /SO. FT. . & $U=0.84$ ) \\
\hline $\begin{array}{l}\text { HEATING ENERGY } \\
* * *+* * * *^{*}\end{array}$ & $\begin{array}{l}S C=0.1 \\
* * * * * *\end{array}$ & $\begin{array}{l}S C=0.2 \\
* * * * *\end{array}$ & $\begin{array}{l}S C=0.4 \\
* * * * * *\end{array}$ & $\begin{array}{l}S C=0.6 \\
* * * *\end{array}$ & $\begin{array}{l}S C=0.8 \\
* * * \ldots\end{array}$ & $\begin{array}{l}S C=1.0 \\
* * * * *\end{array}$ \\
\hline $\begin{array}{l}\text { GAS } \\
\text { OIL } \\
\text { STEAM }\end{array}$ & $\begin{array}{r}9.0 \\
9.0 \\
>30.0\end{array}$ & $\begin{array}{r}7.0 \\
7.0 \\
11.0\end{array}$ & $\begin{array}{l}6.0 \\
6.0 \\
7.0\end{array}$ & $\begin{array}{l}7.0 \\
7.0 \\
6.0\end{array}$ & $\begin{array}{l}7.0 \\
7.0 \\
6.0\end{array}$ & $\begin{array}{r}10.0 \\
10.0 \\
6.0\end{array}$ \\
\hline
\end{tabular}

SAVINGS-TO-INVESTMENT RATIOS FOR SOLAR SCREENS (COST= $\$ 1.0 /$ SQ. FT, U U $=0.84$ )

\begin{tabular}{crrrrrr} 
HEATING ENERGY & \multicolumn{1}{c}{$S C=0.1$} & SC=0.2 & SC=0.4 & SC=0.6 & $S C=0.8$ & $S C=1.0$ \\
GAS & 1.1 & 1.3 & 1.5 & 1.5 & 1.3 & 1.1 \\
OIL & 1.1 & 1.3 & 1.5 & 1.5 & 1.3 & 1.1 \\
STEAM & .6 & 1.0 & 1.4 & 1.6 & 1.6 & 1.5
\end{tabular}

10 YEAR PRESENT WCRTH FACTOR = 9.5(GAS), 8.O(OIL), 8.1(STEAM). 8.1(ELEC) MATERIAL \& INSTALLATION COST $=\$ 42 \mathrm{COO}$.

PAY-BACK PERIOOS (YEARS) FOR SOLAR SCREENS (COST= $\$ 3.0 / 50$. FT. U U $=0.84$ )

$\begin{array}{ccccccc}\text { HEATING ENERGY } & S C=0.1 & S C=0.2 & S C=0.4 & S C=0.6 & S C=0.8 & S C=1.0 \\ \text { GAS } & >30.0 & >30.0 & >30.0 & >30.0 & >30.0 & >30.0 \\ \text { OIL } & >30.0 & >30.0 & >30.0 & >30.0 & >30.0 & >30.0 \\ \text { STEAM } & >30.0 & >30.0 & >30.0 & >30.0 & >30.0 & >30.0\end{array}$

SAVINGS-TO-INVESTMENT RATIOS FOR SOLAR SCREENS (COST $=\$ 3.0 / 50$. FT., U=0.84)

$\begin{array}{crrrrrr}\text { HEATING ENERGY } & S C=0.1 & S C=0.2 & S C=0.4 & S C=0.6 & S C=0.8 & S C=1.0 \\ \text { GA } & .4 & .6 & .7 & .7 & .7 & .7 \\ \text { OIL } & .3 & .5 & .7 & .7 & .7 & .7 \\ \text { STEAM } & .2 & .4 & .7 & .8 & .8 & .8\end{array}$

20 YEAR PRESENT WORTH FACTOR $=15.6$ (GAS), 14.6(OIL). 12.2(STEAM). 11.4(ELEC) MATERIAL \& INSTALLATION COST $=\$ 126000$.

PAY-BAEK PERIODS (YEARS) FOR SOLAR SCREENS (COST=\$6.0/SO. FT.. U=0.84)

\begin{tabular}{|c|c|c|c|c|c|c|}
\hline HEATING ENERGY & $S C=0.1$ & $S C=0.2$ & $S C=0.4$ & $S C=0.6$ & $S C=0.8$ & $S C=1.0$ \\
\hline 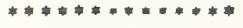 & $* * * * * *$ & $* * * * *$ & $*$ & 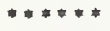 & $* * * * *$ & $* * * * *$ \\
\hline $\begin{array}{l}\text { GAS } \\
\text { OIL }\end{array}$ & $\begin{array}{l}>30.0 \\
>30.0\end{array}$ & $\begin{array}{l}>30.0 \\
>30.0\end{array}$ & $\begin{array}{l}>30.0 \\
>30.0\end{array}$ & $\begin{array}{l}>30.0 \\
>30.0\end{array}$ & $\begin{array}{l}>30.0 \\
>30.0\end{array}$ & $\begin{array}{l}>30.0 \\
>30.0\end{array}$ \\
\hline STEAM & $>30.0$ & $>30.0$ & $>30.0$ & $>30.0$ & $>30.0$ & $>30.0$ \\
\hline
\end{tabular}

SAVINGS-TO-INVESTMENT RATIOS FOR SOLAR SCREENS (COST= $\$ 6.0 /$ SO. FT., U $=0.84$ )

$\begin{array}{crrrrrr}\text { HEATING ENERGY } & S C=0.1 & S C=0.2 & S C=0.4 & S C=0.6 & S C=0.8 & S C=1.0 \\ \text { GAS } & .2 & .3 & .4 & .4 & .4 & .4 \\ \text { OIL } & .1 & .2 & .4 & .4 & .5 & .5 \\ \text { STEAM } & .1 & .2 & .4 & .4 & .5 & .5\end{array}$

30 YEAR PRESENT WORTH FACTOR $=19.8$ (GAS), 20.9(OIL), 14.7(STEAM), 12.7(ELEC) MATERIAL \& INSTALLATION COST $=\$ 252000$. 
Table 11c. Cost-effectiveness for Boston $U=0.50$, All-year Cooling FIRST YEAR ENERGY SAVINGS (DOLLARS) FOR SOLAR SCREENS ( $U=\varnothing .5 \varnothing)$

\begin{tabular}{|c|c|c|c|c|c|c|}
\hline 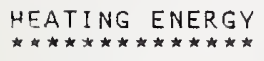 & $\begin{array}{l}S C=\not d, 1 \\
\star \star \star \star \star \star \star\end{array}$ & $\begin{array}{l}S C=\varnothing \cdot 2 \\
\star \star \star \star * * * *\end{array}$ & $\begin{array}{l}\mathrm{SC}=\varnothing \cdot 4 \\
\star \star \star \star \star \star \star *\end{array}$ & $\begin{array}{l}S C=\varnothing .6 \\
\star \star \star \star \star \star \star *\end{array}$ & $\begin{array}{l}S C=\varnothing .8 \\
\star \star \star \star \star *\end{array}$ & $\begin{array}{l}S C=1.0 \\
\star \star \star \star \star \star \star * *\end{array}$ \\
\hline $\begin{array}{l}\text { GAS } \\
\text { OIL } \\
\text { STEAM }\end{array}$ & $\begin{array}{l}22271 . \\
22699 . \\
23593 .\end{array}$ & $\begin{array}{l}20478 . \\
211119 . \\
22458 .\end{array}$ & $\begin{array}{l}17251 . \\
18297 . \\
20481 .\end{array}$ & $\begin{array}{r}9560 . \\
16209 . \\
11567 .\end{array}$ & $\begin{array}{r}8756 . \\
18418 . \\
13889 .\end{array}$ & $\begin{array}{r}4750 . \\
6723 . \\
18844 .\end{array}$ \\
\hline
\end{tabular}

ASSUMPTIONS: $\quad$ ELECTRICITY COST $=\$ . \varnothing 87 / \mathrm{KWH}$ HEATING FUEL COST $=\$ . \varnothing 29(\mathrm{GAS}), . \varnothing 35(\mathrm{OIL}), . \varnothing 47($ STEAM) $/ \mathrm{KWH}$

PAY-BACK PERIODS (YEARS) FOR SOLAR SCREENS (COST $=\$ 1 . \varnothing / S Q . F T ., U=\varnothing .5 \varnothing$ )

\begin{tabular}{|c|c|c|c|c|c|c|}
\hline 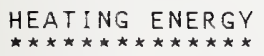 & $\begin{array}{l}S C=\emptyset .1 \\
\star \star \star \star \star \star \star\end{array}$ & $\begin{array}{l}\mathrm{SC}=\varnothing, 2 \\
\star \star \star \star \star \star \star \star\end{array}$ & $\begin{array}{l}\mathrm{SC}=\varnothing .4 \\
\star \star \star \star \star \star \star\end{array}$ & $\begin{array}{l}S C=\varnothing .6 \\
\star \star \star \star * * * *\end{array}$ & $\begin{array}{l}\mathrm{SC}=x .8 \\
\star * * * * *\end{array}$ & $S C=1 . \varnothing$ \\
\hline $\begin{array}{l}\text { GAS } \\
\text { OIL }\end{array}$ & 2. & $\begin{array}{l}3.0 \\
3.0\end{array}$ & $\begin{array}{l}3 . \varnothing \\
3.0\end{array}$ & $\begin{array}{l}5 . \varnothing 0 \\
5 . \not\end{array}$ & $\begin{array}{l}5.0 \\
5.0\end{array}$ & $\begin{array}{l}8.0 \\
8 . \varnothing\end{array}$ \\
\hline STEAM & $2 . \varnothing$ & $2 . \varnothing$ & 3.0 & 4.0 & 4.0 & 4.0 \\
\hline
\end{tabular}

SAVINGS-TO-INVESTMENT RATIOS FOR SOLAR SCREENS $(C O S T=\$ 1 . \varnothing / S Q . \quad F T ., U=\varnothing .5 \varnothing)$

\begin{tabular}{|c|c|c|c|c|c|c|}
\hline HEAT ING ENERGY & $S C=\emptyset .1$ & $S C=\varnothing .2$ & $S C=\varnothing .4$ & $S C=\varnothing .6$ & $S C=\varnothing .8$ & $S C=1 . \varnothing$ \\
\hline $\begin{array}{l}\text { GAS } \\
\text { OIL }\end{array}$ & $\begin{array}{r}4.3 \\
4.4\end{array}$ & $4 . \varnothing$ & 3.5 & 1.9 & $\begin{array}{r}2.0 \\
2 . \varnothing\end{array}$ & $\begin{array}{l}1.2 \\
1.3\end{array}$ \\
\hline
\end{tabular}

10 YEAR PRESENT WORTH FACTOR $=9.5$ (GAS), 8.0 (OIL), 8.1 (STEAM), 8.1 (ELEC) MATER IAL \& INSTALLATION COST $=\$ 42 \varnothing \varnothing \varnothing$.

PAY-BACK PERIODS (YEARS) FOR SOLAR SCREENS (COST $=\$ 3 . \varnothing / S Q . F T . \quad U=\varnothing .5 \nexists$ )

\begin{tabular}{|c|c|c|c|c|c|c|}
\hline 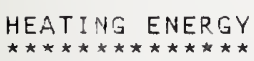 & 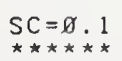 & $\begin{array}{l}S C=\emptyset \cdot 2 \\
\star * \star \star \star * *\end{array}$ & $\begin{array}{l}S C=\varnothing .4 \\
\star \star \star \star \star *\end{array}$ & $\begin{array}{l}\mathrm{SC}=\varnothing .6 \\
\star \star \star \star \star * *\end{array}$ & $\begin{array}{l}S C=0.8 \\
\star \star \star \star * \star *\end{array}$ & $\begin{array}{l}S C=1 . \varnothing \\
S * * * * *\end{array}$ \\
\hline $\begin{array}{l}\text { GAS } \\
\text { OIL }\end{array}$ & $\begin{array}{l}7.0 \\
7.8\end{array}$ & $\begin{array}{l}7.0 \\
7.0\end{array}$ & $\begin{array}{l}9.8 \\
9.87\end{array}$ & $\begin{array}{l}22.0 \\
20.0\end{array}$ & $\begin{array}{l}19.0 \\
17.0\end{array}$ & $\begin{array}{l}30.0 \\
23.8\end{array}$ \\
\hline STEAM & $6 . \varnothing$ & 7.0 & 7.0 & 17.0 & $12 . \varnothing$ & 18.8 \\
\hline
\end{tabular}

SAVINGS-TO-INVESTMENT RATIOS FOR SOLAR SCREENS (COST $=\$ 3 . \varnothing / S Q . \quad F T ., U=\varnothing .50)$

\begin{tabular}{|c|c|c|c|c|c|c|}
\hline HEATIING ENERGY & 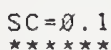 & $\begin{array}{l}S C=\varnothing .2 \\
\star \star \star \star \star \star * \star *\end{array}$ & $\begin{array}{l}S C=\varnothing .4 \\
* \star \star \star * * *\end{array}$ & 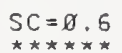 & $\begin{array}{l}S C=\varnothing .8 \\
\star \star \star \star \star \star\end{array}$ & $\begin{array}{l}\mathrm{SC}=1 . \varnothing \\
\star \star \star \star \star \star \star\end{array}$ \\
\hline GAS & 2.1 & $2 . \varnothing$ & 1.7 & $1 . \varnothing$ & 1. 1 & 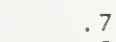 \\
\hline OIL & 2.1 & 2.0 & 1.8 & 1.0 & 1.2 & 1 \\
\hline STEAM & 2.2 & 2.1 & 1.9 & 1.1 & 1.3 & 1.1 \\
\hline
\end{tabular}

20 YEAR PRESENT WORTH FACTOR = 15.6 (GAS), 14.6 (OIL). 12.2 (STEAM), 11.4 (ELEC) MATERIAL \& INSTALLATION COST $=\$ 12600$. .

PAY-BACK PERIODS (YEARS) FOR SOLAR SCREENS (COST $=\$ 5 . \varnothing / S Q$. FT., U= $\varnothing .5 \varnothing$ )

\begin{tabular}{|c|c|c|c|c|c|c|}
\hline 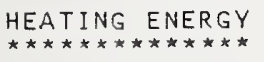 & $\begin{array}{l}S C=\varnothing .1 \\
\star \star \star \star \star \star \star\end{array}$ & $\begin{array}{l}\mathrm{SC}=\emptyset \cdot 2 \\
\star \star \star \star \star \star \star \star\end{array}$ & $\begin{array}{l}S C=\varnothing .4 \\
\star \star \star \star \star \star \star\end{array}$ & $\begin{array}{l}S C=0.6 \\
* * * * * *\end{array}$ & $\begin{array}{l}\mathrm{SC}=\varnothing .8 \\
\star \star \star \star \star \star \star\end{array}$ & $\begin{array}{l}S C=1 . \emptyset \\
\star \star \star \star \star * \star *\end{array}$ \\
\hline $\begin{array}{l}\text { GAS } \\
\text { OIL } \\
\text { STEAM }\end{array}$ & $\begin{array}{l}19.0 \\
18.0 \\
17.0\end{array}$ & $\begin{array}{l}22 . \varnothing \\
2 \varnothing . \varnothing \\
19 . \varnothing\end{array}$ & $\begin{array}{l}30.9 \\
25.9 \\
23.0\end{array}$ & $\begin{array}{r}>3.0 . \varnothing \\
.>30.0 \\
>30 . \varnothing\end{array}$ & $\begin{array}{l}>3.0 . \varnothing \\
30.0 \\
>30 . \varnothing\end{array}$ & $\begin{array}{l}>30.0 \\
>30.0 \\
>30.0\end{array}$ \\
\hline
\end{tabular}

SAVINISS-TO-INVESTMENT RATIOS FOR SOLAR SCREENS (COST $=\$ 6 . \varnothing / S Q$. FT. U U $=\varnothing .5 \varnothing)$

\begin{tabular}{|c|c|c|c|c|c|c|}
\hline 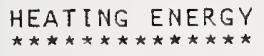 & $\begin{array}{l}\text { SC }=0,1 \\
\star \star \star \star \star \star *\end{array}$ & $\begin{array}{l}S C=\varnothing .2 \\
\star \star \star \star \star \star \star\end{array}$ & $\begin{array}{l}\mathrm{SC}=\varnothing \cdot 4 \\
\star \star \star \star * *\end{array}$ & $\begin{array}{l}S C=\varnothing .6 \\
\star * * * * *\end{array}$ & $\begin{array}{l}\mathrm{SC}=\varnothing .8 \\
\star \star \star \star \star \star\end{array}$ & $\begin{array}{l}S C=1.6 \\
\star \star \star \star \star *\end{array}$ \\
\hline $\begin{array}{l}\text { GAS } \\
\text { OIL }\end{array}$ & $\begin{array}{l}1.2 \\
1.2\end{array}$ & $\begin{array}{l}1.1 \\
1.2 \\
1.2\end{array}$ & $\begin{array}{l}1.0 \\
1.1 \\
1.1\end{array}$ & $\begin{array}{l}.6 \\
.6 \\
.6\end{array}$ & $\begin{array}{r}.7 \\
.8 \\
.8\end{array}$ & $\begin{array}{l}.5 \\
.7 \\
.7\end{array}$ \\
\hline
\end{tabular}

30 YEAR PRESENT WORTH FACTOR $=19.8$ (GAS), 20.9(OIL), 14.7(STEAM), 12.7(ELEC) MATER IAL \& INSTALLATION COST $=\$ 252000$. 
Table 1ld. Cost-effectiveness for Boston $U=0.84$, All-year Cooling FIRST YEAR ENERGY SAVINGS (DOLLARS) FOR SOLAR SCREENS $\{U=\varnothing .84\}$

\begin{tabular}{|c|c|c|c|c|c|c|}
\hline 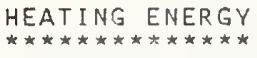 & $\begin{array}{l}S C=\varnothing .1 \\
* * * * * *\end{array}$ & $\begin{array}{l}\mathrm{SC}=\varnothing .2 \\
\star \star \star \star \star \star \star\end{array}$ & $\begin{array}{l}\mathrm{SC}=\emptyset .4 \\
\star \star \star \star \star \star \star\end{array}$ & $\begin{array}{l}\mathrm{SC}=\varnothing .6 \\
\star * * * * *\end{array}$ & $\begin{array}{l}\mathrm{SC}=\varnothing .8 \\
\star \star \star \star \star \star\end{array}$ & $\underset{\star \star \star \star \star \star \star \star *}{\mathrm{SC}=1.0}$ \\
\hline $\begin{array}{l}\text { GAS } \\
\text { OIL } \\
\text { STEAM }\end{array}$ & $\begin{array}{l}15351 . \\
14536 . \\
12834 .\end{array}$ & $\begin{array}{l}14069 . \\
13467 . \\
12209 .\end{array}$ & $\begin{array}{l}11885 . \\
11720 \\
11375 .\end{array}$ & $\begin{array}{l}8769 . \\
8984 . \\
9433 .\end{array}$ & $\begin{array}{l}5738 . \\
6335 . \\
7581 .\end{array}$ & $\begin{array}{l}4644 . \\
5622 . \\
7666 .\end{array}$ \\
\hline
\end{tabular}

ASSUMPTIONS: $\quad$ ELECTRICITY COST $=\$ .087 / \mathrm{KWH}$

HEATING FUEL COST $=\$ .029$ (GAS), .

\begin{tabular}{|c|c|c|c|c|c|c|}
\hline 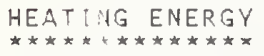 & 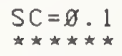 & $\begin{array}{l}S C=\emptyset .2 \\
\star \star \star \star \star \star \star\end{array}$ & $\begin{array}{l}S C=\varnothing .4 \\
\star * \star \star \star \star *\end{array}$ & $\begin{array}{l}S C=0.6 \\
\star \star \star \star \star \star *\end{array}$ & $\begin{array}{l}S C=\varnothing .8 \\
\star \star \star \star \star \star\end{array}$ & $\begin{array}{l}S C=1 . \varnothing \\
\star * \star \star \star \star *\end{array}$ \\
\hline $\begin{array}{l}\text { GAS } \\
\text { OIL } \\
\text { STEAM }\end{array}$ & $\begin{array}{l}3 . \varnothing \\
3.0 \\
4.8\end{array}$ & $\begin{array}{l}4.0 \\
4.0 \\
4.0\end{array}$ & $\begin{array}{l}4.0 \\
4.0 \\
4.8\end{array}$ & $\begin{array}{l}6.0 \\
6.0 \\
5.0\end{array}$ & $\begin{array}{l}8.0 \\
8.0 \\
6.0\end{array}$ & $\begin{array}{r}10 . \varnothing \\
10 . \varnothing \\
6.0\end{array}$ \\
\hline
\end{tabular}

SAVINGS-TO-INVESTMENT RATIOS FOR SOLAR SCREENS (COST $=\$ 1 . \varnothing / S Q . \quad F T ., U=\varnothing .84$ )

\begin{tabular}{|c|c|c|c|c|c|c|}
\hline 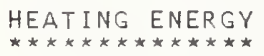 & $\begin{array}{l}S C=\emptyset .1 \\
S_{* * * * * *}\end{array}$ & $\begin{array}{l}S C=\varnothing \cdot 2 \\
* * * * * *\end{array}$ & $\begin{array}{l}S C=\emptyset .4 \\
\star \star \star \star \star * *\end{array}$ & $\begin{array}{l}S C=\varnothing .6 \\
\star \star \star \star \star * *\end{array}$ & $\begin{array}{l}\mathrm{SC}=0.8 \\
\star \star \star \star \star *\end{array}$ & $\begin{array}{l}S C=1 . \varnothing \\
* * * * *\end{array}$ \\
\hline $\begin{array}{l}\text { GAS } \\
\text { OIL } \\
\text { STEAM }\end{array}$ & $\begin{array}{l}2.8 \\
2.8 \\
2.4\end{array}$ & $\begin{array}{l}2.6 \\
2.6 \\
2.3\end{array}$ & $\begin{array}{l}2.3 \\
2.3 \\
2.2\end{array}$ & $\begin{array}{l}1.7 \\
1.7 \\
1.8\end{array}$ & $\begin{array}{l}1.2 \\
1.2 \\
1.5\end{array}$ & \\
\hline
\end{tabular}

$1 \varnothing$ YEAR PRESENT WORTH FACTOR $=9.5$ (GAS), $8.0(O I L), 8.1$ (STEAM), 8.1 (ELEC) MATERIAL \& INSTALLATION COST $=\$ 42000$.

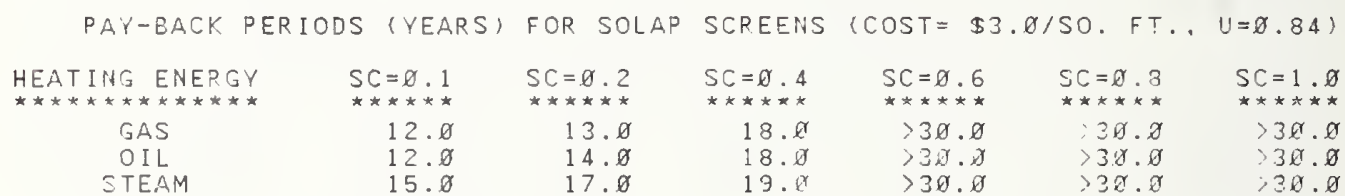

SAVINGS-TO-INVESTMENT PATIOS FOR. SOLAR SCREENS $: L O S T=I 3 . \varnothing / S O . F T ., U=\not .34$ !

\begin{tabular}{|c|c|c|c|c|c|c|}
\hline$\underset{* \star * * * \star * \star * * * \star * \star * \star *}{\operatorname{HEATING}}$ & $\begin{array}{l}S C=\emptyset \cdot 1 \\
\star \star \star \star \star \star \star *\end{array}$ & $\begin{array}{l}S C=\varnothing .2 \\
\star \star \star \star * * *\end{array}$ & $\begin{array}{l}S C=\not .4 \\
\star \star \star \star \star \star \star *\end{array}$ & $\begin{array}{l}S C=0.6 \\
* * * * * *\end{array}$ & $\begin{array}{l}S C=\varnothing .8 \\
* * * * \star *\end{array}$ & $\begin{array}{l}\mathrm{SC}=1 . \varnothing \\
\star \star \star \star \star * *\end{array}$ \\
\hline $\begin{array}{l}\text { GAS } \\
\text { OIL }\end{array}$ & $\begin{array}{l}1.3 \\
1.2\end{array}$ & $\begin{array}{l}1.2 \\
1.1\end{array}$ & $\begin{array}{l}1.0 \\
1.0\end{array}$ & $\begin{array}{l}.8 \\
.8\end{array}$ & .6 & \\
\hline STEAM & 1.1 & 1.1 & $1 . \varnothing$ & .9 & .7 & 7 \\
\hline
\end{tabular}

20 YEAR PRESENT WORTH FACTOR $=15.6$ (GAS), 14.6 (OIL), 12.2 (STEAM), 11.4(ELEC) MATERIAL \& INSTALLATION COST $=\$ 126 \varnothing \varnothing$.

PAY-BACK PERIODS (YEARS) FOR SOLAR SCREENS (COST $=\$ 6 . \varnothing / S O$. FT. U U

\begin{tabular}{|c|c|c|c|c|c|c|}
\hline 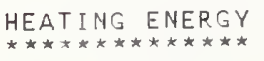 & $\begin{array}{l}S C=\varnothing, 1 \\
\star \star \star \star \star \star \star\end{array}$ & $\begin{array}{l}S C=\varnothing .2 \\
\star \star \star \star \star \star *\end{array}$ & 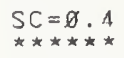 & $\begin{array}{l}S C=0.6 \\
\star \star \star \star \star \star *\end{array}$ & $\begin{array}{l}S C=\varnothing .8 \\
\star \star \star \star \star \star *\end{array}$ & $\begin{array}{l}S C=1 . \varnothing \\
* \star * * \star *\end{array}$ \\
\hline $\begin{array}{l}\text { GAS } \\
\text { OIL } \\
\text { STEAM }\end{array}$ & $\begin{array}{l}>30.0 \\
>30.0 \\
>30.0\end{array}$ & $\begin{array}{l}>30.0 \\
>30.0 \\
>30.0\end{array}$ & $\begin{array}{l}>30.0 \\
>30.0 \\
>30.0\end{array}$ & $\begin{array}{l}>30.0 \\
>30.0 \\
>30.0\end{array}$ & $\begin{array}{l}>30.0 \\
30.0 \\
300.0\end{array}$ & $\begin{array}{l}>30.0 \\
>30.0 \\
>30.0\end{array}$ \\
\hline
\end{tabular}

SAVINGS-TO-INVESTMENT RATIOS FOR SOLAR SCREENS (COST $=\$ 6 . \varnothing / S O . F T . \quad U=\varnothing .84$ )

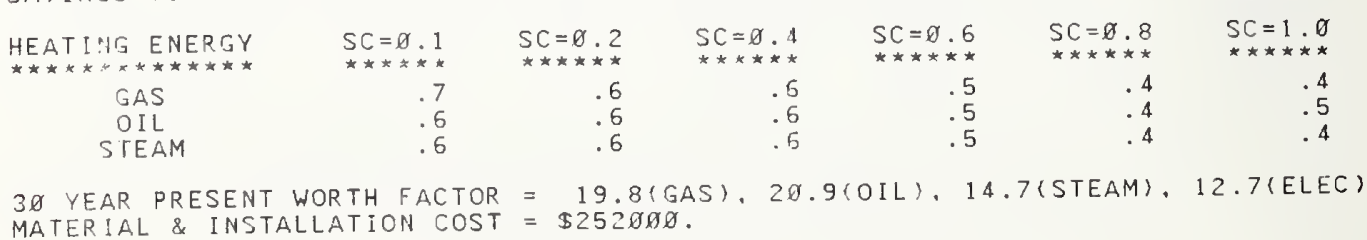




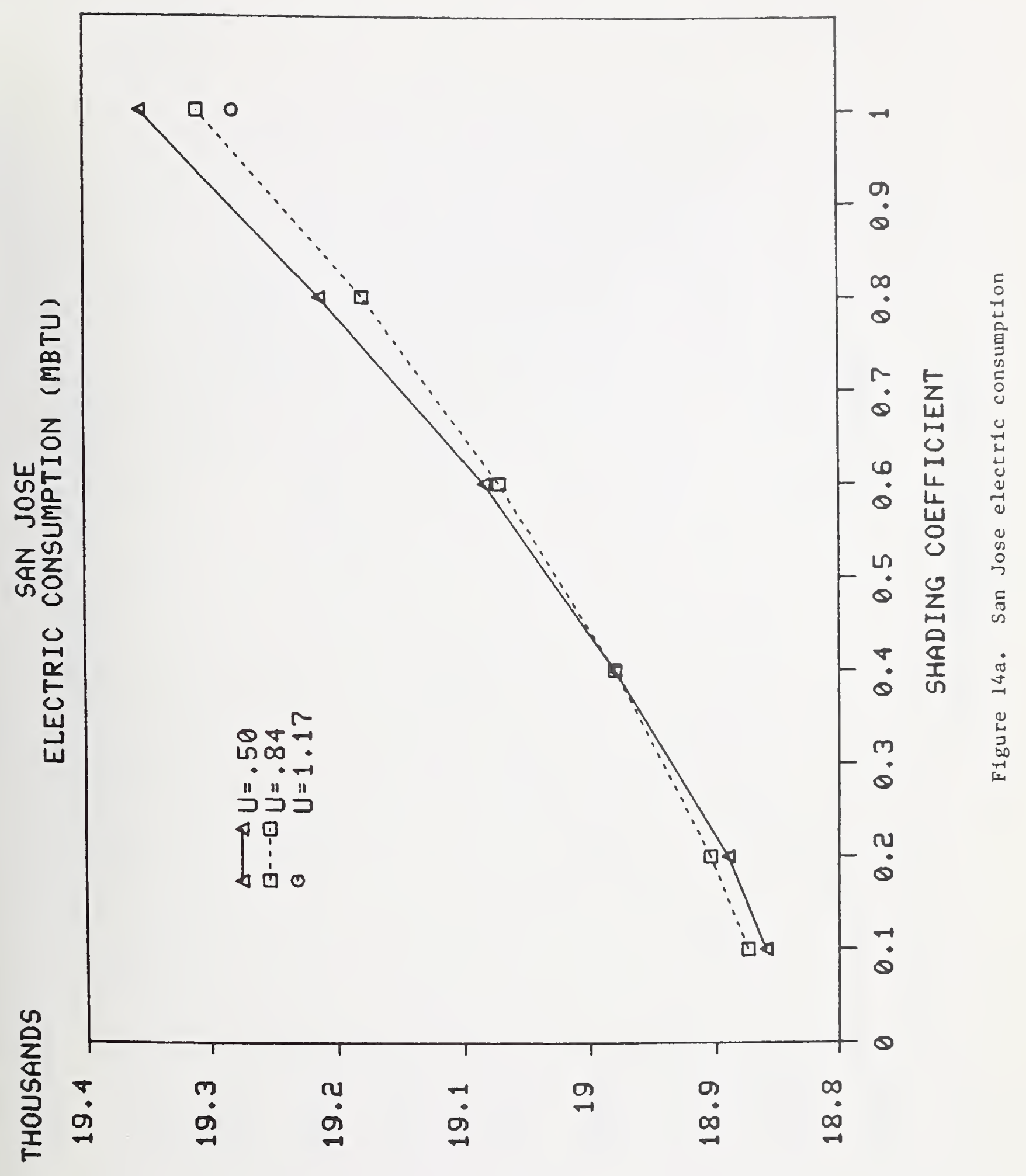

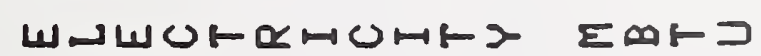




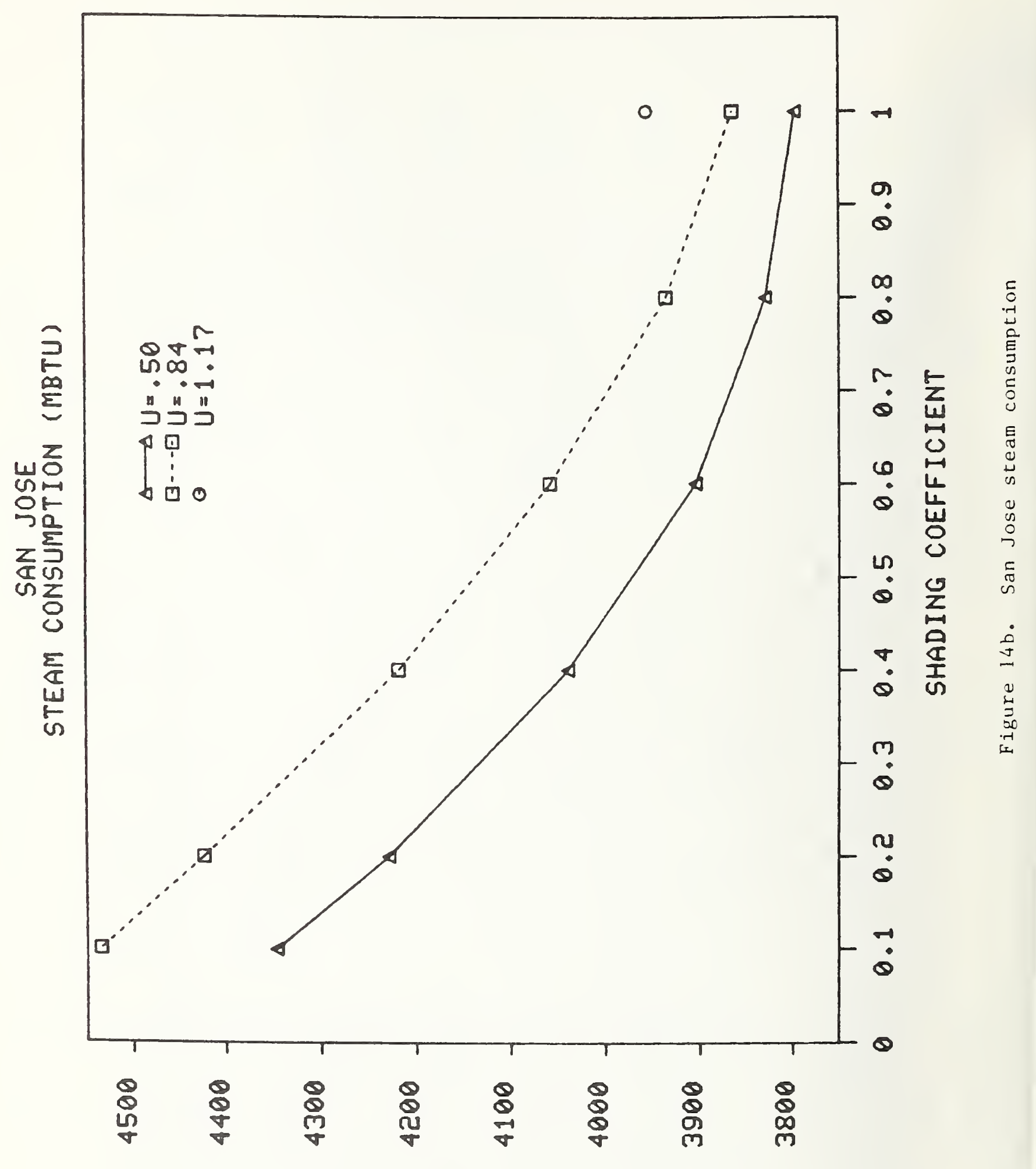

NFWCE 


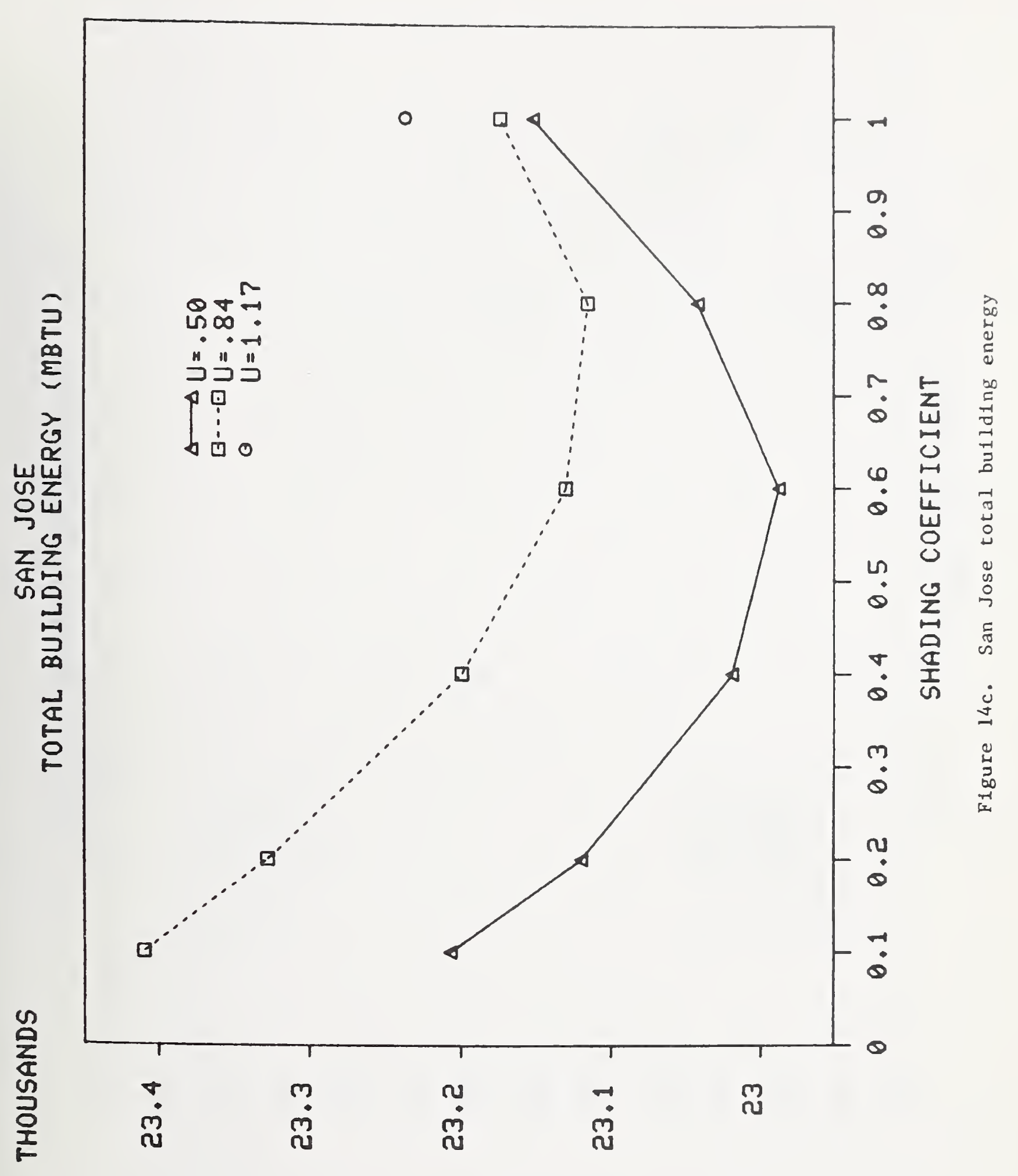

tor 


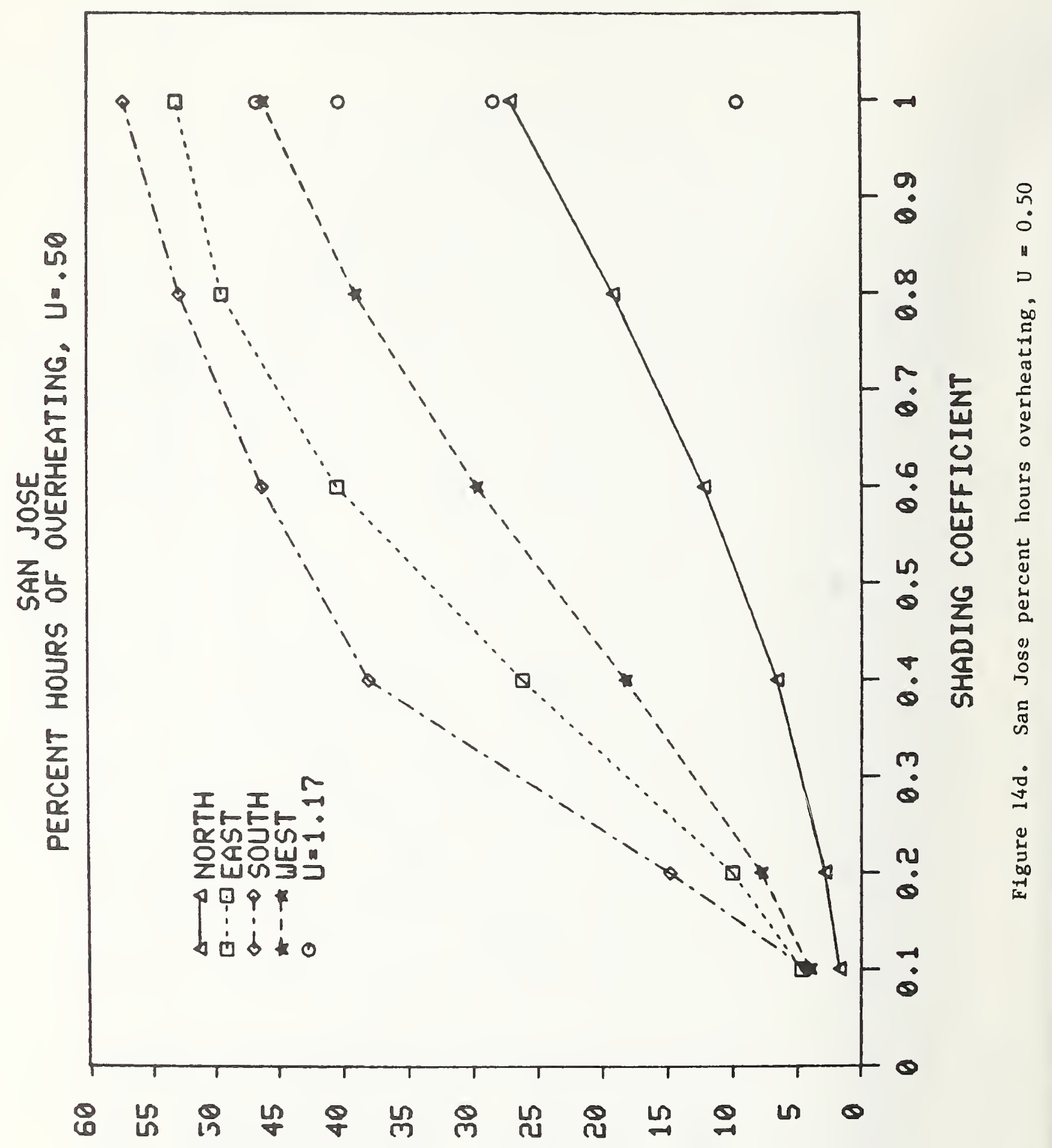

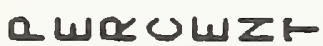




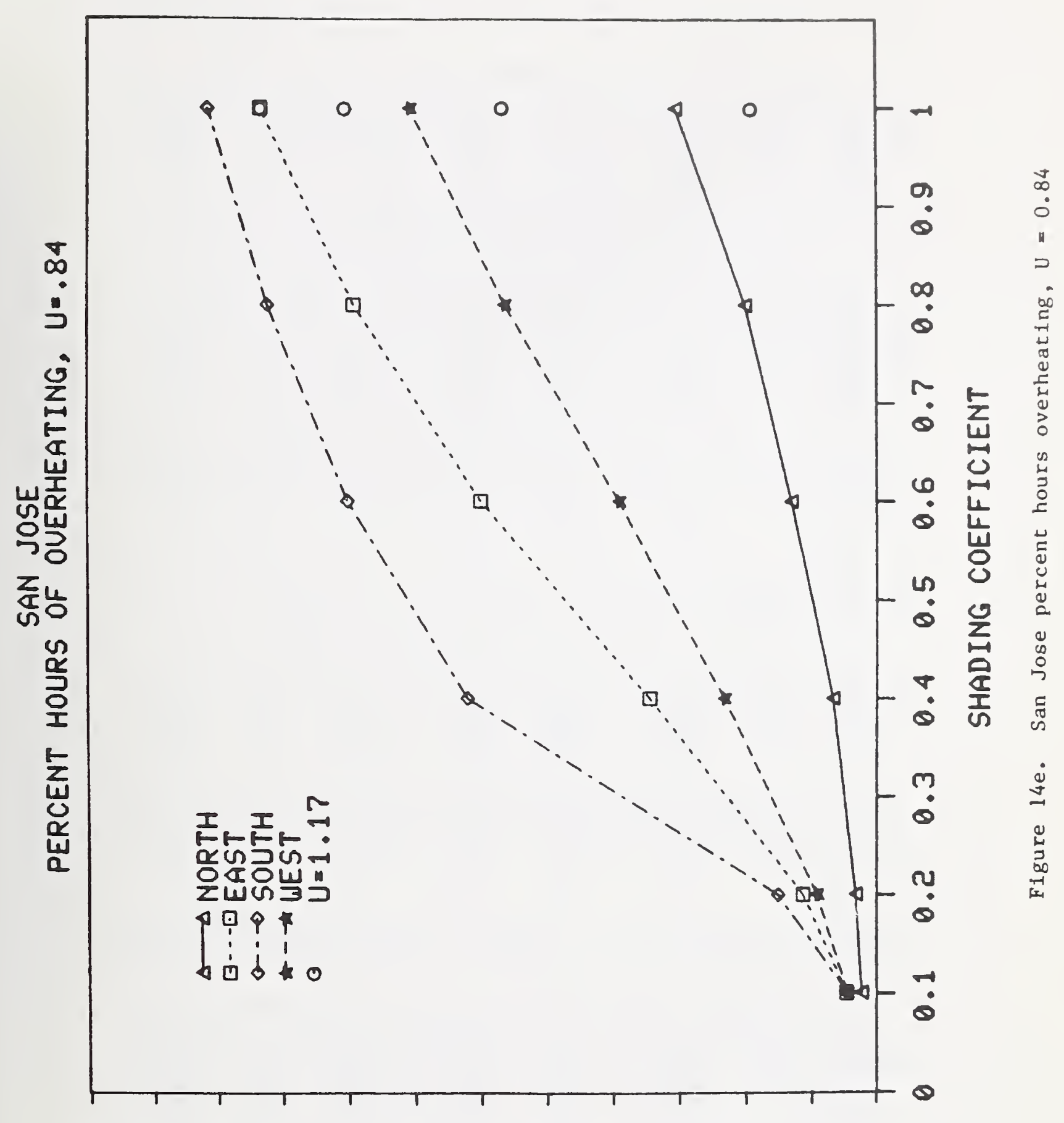

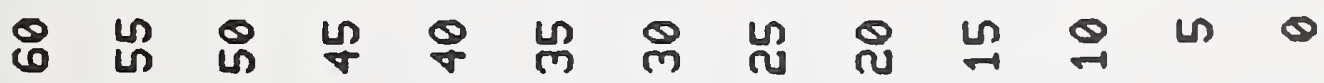

aயवUWZட 
Table 12a. Cost-effectiveness for San Jose $U=0.50$, Sumer-only Cooling

FIRST YEAR ENERGY SAVINGS (DOLLARS) FOR SOLAR SCREENS $(U=0.50)$

\begin{tabular}{|c|c|c|c|c|c|c|}
\hline HEATING ENERGY & $\begin{array}{l}S C=0.1 \\
+\cdots\end{array}$ & $\begin{array}{l}S C=0.2 \\
\end{array}$ & $\begin{array}{l}S C=0.4 \\
*\end{array}$ & $S C=0.6$ & $\begin{array}{l}S C=0.8 \\
\end{array}$ & $\begin{array}{l}S C=1.0 \\
* \cdots *\end{array}$ \\
\hline $\begin{array}{l}\text { GAS } \\
\text { OIL } \\
\text { STEAM }\end{array}$ & $\begin{array}{l}4960 . \\
3255 . \\
2545 .\end{array}$ & $\begin{array}{l}5216 . \\
4023 . \\
3527 .\end{array}$ & $\begin{array}{l}4896 \\
4532 \\
4381\end{array}$ & $\begin{array}{l}3942 \\
4168 \\
4263\end{array}$ & $\begin{array}{l}2099 . \\
2654 \\
2885\end{array}$ & $\begin{array}{r}-250 . \\
445 . \\
734 .\end{array}$ \\
\hline
\end{tabular}

ASSUMPTIONS: ELECTRICITY COST $=\$ .062 / \mathrm{KWH}$

HEATING FIJEL COST $=$ S.023(GAS), .038(OIL), .045(STEAM)/KWH

PAY-BACK PERIODS (YEARS) FOR SOLAR SCREENS (COST $=\$ 1.0 / S O$. FT.. U U $=0.50$ )

$\begin{array}{crrrrrr}\text { HEATING ENERGY } & S C=0.1 & S C=0.2 & S C=0.4 & S C=0.6 & S C=0.8 & S C=1.0 \\ \text { GAS } & 12.0 & 11.0 & 11.0 & 15.0 & >30.0 & >30.0 \\ \text { OIL } & >30.0 & 18.0 & 12.0 & 14.0 & 25.0 & >30.0 \\ \text { STEAM } & >30.0 & 25.0 & 13.0 & 13.0 & 26.0 & >30.0\end{array}$

SAVINGS-TO-INVESTMENT RATIOS FOR SOLAR SCREENS (COST $=\$ 1.0 / S O$. FT. U U=0.50)

$\begin{array}{crrrrrr}\text { HEATING ENERGY } & S C=0.1 & S C=0.2 & S C=0.4 & S C=0.6 & S C=0.8 & S C=1.0 \\ \text { GAS } & .9 & 1.0 & .9 & .8 & .4 & \ldots \\ \text { OIL } & .7 & .8 & .9 & .8 & .5 & .1 \\ \text { STEAM } & .4 & .7 & .8 & .8 & .6 & .2\end{array}$

10 YEAR PRESENT WORTH FACTOR = 9.2(GAS), 8.O(OIL), 8.7(STEAM). 8.3(ELEC) MATERIAL \& INSTALLATION COST $=\$ 42000$.

FAY-BACK PERIODS (YEARS) FOR SOLAR SCREENS (COST $=\$ 3.0 / 50$. FT., U=0.50)

$\begin{array}{ccccccc}\text { HEATING ENERGY } & S C=0.1 & S C=0.2 & S C=0.4 & S C=0.6 & S C=0.8 & S C=1.0 \\ \text { GAS } & >30.0 & >30.0 & >30.0 & >30.0 & >30.0 & >30.0 \\ \text { OIL } & >30.0 & >30.0 & >30.0 & >30.0 & >30.0 & >30.0 \\ \text { STEAM } & >30.0 & >30.0 & >30.0 & >30.0 & >30.0 & >30.0\end{array}$

SAVINGS-TO-INVESTMENT RATIOS FOR SOLAR SCREENS (COST=\$3.0/SQ. FT., U=0.50)

$\begin{array}{crrrrrr}\text { HEATING ENERGY } & S C=0.1 & S C=0.2 & S C=0.4 & S C=0.6 & S C=0.8 & S C=1.0 \\ \text { GAS } & .4 & .5 & .5 & .4 & .2 & \ldots . . \\ \text { OIL } & .2 & .3 & .4 & .4 & .3 & .1 \\ \text { STEAM } & .2 & .3 & .4 & .4 & .3 & .1\end{array}$

20 YEAR PRESENT WCRTH FACTOR = 14.3(GAS), 14.8(OIL), 13.6(STEAM). 12.4(ELEC) MATERIAL \& INSTALLATION CCST $=\$ 126000$.

PAY-BACK PERIODS (YEARS) FOR SOLAR SCREENS (COST $=\$ 6.0 / S O$. FT. U U=0.50)

$\begin{array}{ccccccc}\text { HEATING ENERGY } & S C=0.1 & S C=0.2 & S C=0.4 & S C=0.6 & S C=0.8 & S C=1.0 \\ \text { GAS } & >30.0 & >30.0 & >30.0 & >30.0 & >30.0 & >30.0 \\ \text { OIL } & >30.0 & >30.0 & >30.0 & >30.0 & >30.0 & >30.0 \\ \text { STEAM } & >30.0 & >30.0 & >30.0 & >30.0 & >30.0 & >30.0\end{array}$

SAVINGS-TO-INVESTMENT RATIOS FOR SOLAR SCREENS (COST=\$6.0/SO. FT., U=0.50)

$\begin{array}{crrrrrr}\text { HEATING ENERGY } & S C=0.1 & S C=0.2 & S C=0.4 & S C=0.6 & S C=0.8 & S C=1.0 \\ \text { GAS } & .3 & .3 & .3 & .2 & .1 & \ldots \\ \text { OIL } & .1 & .1 & .2 & .3 & .2 & .1 \\ \text { STEAM } & .1 & .2 & .2 & .3 & .2 & .1\end{array}$

30 YEAR PRESENT WORTH FACTOR $=17.3$ (GAS), 21.3(OIL), 16.2(STEAM), 14.5(ELEC) MATERIAL \& INSTALLATION COST $=\$ 252000$. 
Table 12b. Cost-effectiveness for San Jose $U=0.84$, Summer-only Cooling

FIRST YEAR ENERGY SAVINGS (DOLLARS) FOR SOLAR SCREENS (U=0.84)

$\begin{array}{crrrrrr}\text { HEATING ENERGY } & S C=0.1 & S C=0.2 & S C=0.4 & S C=0.6 & S C=0.8 & S C=1.0 \\ \text { GAS } & 3407 . & 3637 . & 3658 . & 3098 . & 1978 . & 117 . \\ \text { OIL } & 878 . & 1599 . & 2510 . & 2652 . & 2068 . & 516 . \\ \text { STEAM } & -175 . & 750 . & 2031 . & 2466 . & 2105 . & 682 .\end{array}$

ASSUMPTIONS: $\quad$ ELECTRICITY COST $=\$ .062 / \mathrm{KWH}$

HEATING FUEL COST $=\$ .023$ (GAS), .038(OIL),.045(STEAM)/KWH

PAY-BACK PERIODS (YEARS) FOR SOLAR SCREENS (COST= $\$ 1.0 / 50$. FT, U U 0.84 )

$\begin{array}{crrrrrr}\text { HEATING ENERGY } & S C=0.1 & S C=0.2 & S C=0.4 & S C=0.6 & S C=0.8 & S C=1.0 \\ \text { GAS } & >30.0 & 27.0 & 21.0 & 29.0 & >30.0 & >30.0 \\ \text { OIL } & >30.0 & >30.0 & >30.0 & >30.0 & >30.0 & >30.0 \\ \text { STEAM } & >30.0 & >30.0 & >30.0 & >30.0 & >30.0 & >30.0\end{array}$

SAVINGS-TO-INVESTMENT RATIOS FOR SOLAR SCREENS (COST. $\$ 1.0 / S O$. FT.. U=0.84)

\begin{tabular}{|c|c|c|c|c|c|c|}
\hline HEATING ENERGY & $\begin{array}{l}S C=0.1 \\
* * * *\end{array}$ & $S C=0.2$ & $S C=0.4$ & $\begin{array}{l}S C=0.6 \\
* * \ldots\end{array}$ & SC $=0.8$ & $S C=1.0$ \\
\hline $\begin{array}{l}\text { GAS } \\
\text { OIL } \\
\text { STEAM }\end{array}$ & $\begin{array}{r}.6 \\
.2 \\
. .2\end{array}$ & $\begin{array}{l}.6 \\
.3 \\
.1\end{array}$ & $\begin{array}{l}.7 \\
.5 \\
.4\end{array}$ & $\begin{array}{l}.6 \\
.5 \\
.5\end{array}$ & $\begin{array}{l}.4 \\
.4 \\
.4\end{array}$ & $\begin{array}{r}.0 \\
.1 \\
.1\end{array}$ \\
\hline
\end{tabular}

10 YEAR PRESENT WORTH FACTOR = 9.2(GAS). 8.O(OIL). 8.7(STEAM). 8.3(ELEC) MATERIAL \& INSTALLATION COST $=\$ 42000$.

PAY-BACK PERIODS (YEARS) FOR SOLAR SCREENS (COST $=\$ 3.0 / S O$. FT. $U=0.84$ )

$\begin{array}{ccccccc}\text { HEATING ENERGY } & S C=0.1 & \text { SC=0.2 } & S C=0.4 & S C=0.6 & S C=0.8 & S C=1.0 \\ \text { GAS } & >30.0 & >30.0 & >30.0 & >30.0 & >30.0 & >30.0 \\ \text { OIL } & >30.0 & >30.0 & >30.0 & >30.0 & >30.0 & >30.0 \\ \text { STEAM } & >30.0 & >30.0 & >30.0 & >30.0 & >30.0 & >30.0\end{array}$

SAVINGS-TO-INVESTMENT RATIOS FOR SOLAR SCREENS (COST $=\$ 3.0 / S Q$. FT.. U $=0.84$ )

\begin{tabular}{|c|c|c|c|c|c|c|}
\hline HEATING ENERGY & $S C=0.1$ & $S C=0.2$ & SC $=0.4$ & $\begin{array}{l}S C=0.6 \\
\ldots\end{array}$ & $\begin{array}{l}S C=0.8 \\
* *=\end{array}$ & $S C=1.0$ \\
\hline $\begin{array}{l}\text { GAS } \\
\text { OIL } \\
\text { STEAM }\end{array}$ & $\begin{array}{r}.3 \\
\ldots . \\
\ldots .\end{array}$ & $\begin{array}{l}.3 \\
.1 \\
.0\end{array}$ & $\begin{array}{l}.3 \\
.2 \\
.2\end{array}$ & $\begin{array}{l}.3 \\
.2 \\
.2\end{array}$ & $\begin{array}{l}.2 \\
.2 \\
.2\end{array}$ & $\begin{array}{l}.0 \\
.1 \\
.1\end{array}$ \\
\hline
\end{tabular}

20 YEAR PRESENT WORTH FACTOR $=14.3$ (GAS), 14.8(OIL), 13.6(STEAM), 12.4(ELEC) MATERIAL \& INSTALLATION COST $=\$ 126000$.

PAY-BACK PERIODS (YEARS) FOR SOLAR SCREENS (COST $=\$ 6.0 / 5 O$. FT. U U $=0.84$ )

$\begin{array}{ccccccc}\text { HEATING ENERGY } & S C=0.1 & S C=0.2 & S C=0.4 & S C=0.6 & S C=0.8 & S C=1.0 \\ \text { GAS } & >30.0 & >30.0 & >30.0 & >30.0 & >30.0 & >30.0 \\ \text { OIL } & >30.0 & >30.0 & >30.0 & >30.0 & >30.0 & >30.0 \\ \text { STESM } & >30.0 & >30.0 & >30.0 & >30.0 & >30.0 & >30.0\end{array}$

SAVINGS-TO-INVESTMENT RATIOS FOR SOLAR SCREENS (COST= $56.0 / S O$. FT. U U 0.84 )

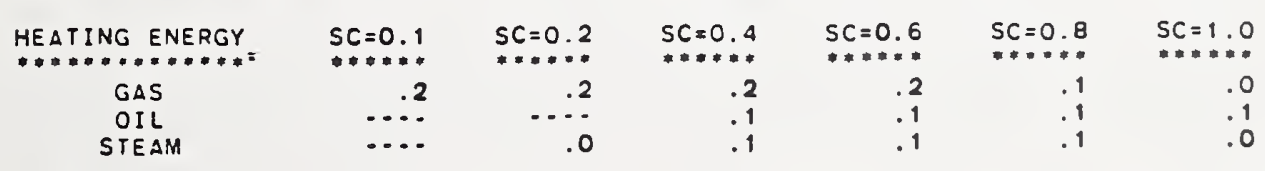

30 YEAR PRESENT WORTH FACTOR $=17.3$ (GAS), 21.3(OIL), 16.2(STEAM). 14.5(ELEC) MATERIAL \& INSTALLATICN COST $=\$ 252000$. 
Table 12c. Cost-effectiveness for San Jose $U=0.50$, Al1-year Cooling FIRST YEAR ENERGY SAVINGS (DOLLARS) FOR SOLAR SCREENS $(U=\varnothing .5 \varnothing)$

\begin{tabular}{|c|c|c|c|c|c|c|}
\hline 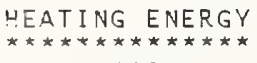 & $\begin{array}{l}\mathrm{SC}=\varnothing \cdot 1 \\
\star \star \star \star \star \star \star\end{array}$ & $\begin{array}{l}\mathrm{SC}=\varnothing .2 \\
\star \star \star \star \star \star \star\end{array}$ & $\begin{array}{l}\mathrm{SC}=\emptyset \cdot 4 \\
\star \star \star \star \star \star \star\end{array}$ & $\begin{array}{l}\mathrm{SC}=\varnothing .6 \\
\star \star \star \star \star \star\end{array}$ & $\begin{array}{l}\mathrm{SC}=\varnothing .8 \\
\star \star \star \star \star \star \star\end{array}$ & $\begin{array}{l}\mathrm{SC}=1 . \varnothing \\
\star \star \star \star \star \star\end{array}$ \\
\hline $\begin{array}{l}\text { GAS } \\
\text { OIL } \\
\text { STEAM }\end{array}$ & $\begin{array}{l}15770 . \\
14822 . \\
14427 .\end{array}$ & $\begin{array}{l}13869 . \\
13157 . \\
12861 .\end{array}$ & $\begin{array}{l}97162 . \\
9449 . \\
9344 .\end{array}$ & $\begin{array}{l}5799 . \\
6022 \\
6115\end{array}$ & $\begin{array}{l}1810 . \\
2500 . \\
2788 .\end{array}$ & $\begin{array}{r}-2429 . \\
-1281 . \\
-802 .\end{array}$ \\
\hline
\end{tabular}

ASSUMPTIONS: $\quad$ ELECTRICITY COST $=\$ .062 / \mathrm{KWH}$

HEATING FUEL COST $=\$ .023$ (GAS), . $\$ 38$ (OIL), .

PAY-BACK PERIODS (YEARS) FOR SOLAR SCREENS (COST=\$1.

\begin{tabular}{|c|c|c|c|c|c|c|}
\hline 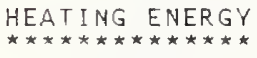 & $\begin{array}{l}\mathrm{SC}=\varnothing \cdot 1 \\
\star \star \star \star \star \star \star\end{array}$ & $\begin{array}{l}S C=\varnothing \cdot 2 \\
S_{\star \star \star *}\end{array}$ & $\begin{array}{l}\mathrm{SC}=\varnothing \cdot 4 \\
\star \star \star \star \star \star\end{array}$ & $\begin{array}{l}\mathrm{SC}=\varnothing .6 \\
\star \star \star \star \star \star \star\end{array}$ & $\begin{array}{l}\mathrm{SC}=x .8 \\
\star \star \star \star \star \star \star\end{array}$ & 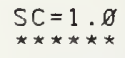 \\
\hline $\begin{array}{l}\text { GAS } \\
\text { OIL } \\
\text { STEAM }\end{array}$ & $\begin{array}{l}3 . \varnothing \\
3 . \varnothing \\
4 . \varnothing\end{array}$ & $\begin{array}{l}4 . \varnothing \\
4 . \varnothing \\
4.0\end{array}$ & $\begin{array}{l}5 . \varnothing \\
5 . \varnothing \\
5 . \varnothing\end{array}$ & $\begin{array}{l}9 . \varnothing \\
9 . \varnothing \\
8 . \varnothing\end{array}$ & $\begin{array}{r}>30.0 \\
26.0 \\
27.0\end{array}$ & $\begin{array}{l}>3 \theta .0 \\
>30.0 \\
>30.0\end{array}$ \\
\hline
\end{tabular}

SAVINGS-TO-INVESTMENT RATIOS FOR SOLAR SCREENS (COST $=\$ 1 . \varnothing / S Q . \quad F T . \quad U=\varnothing .5 \varnothing$ )

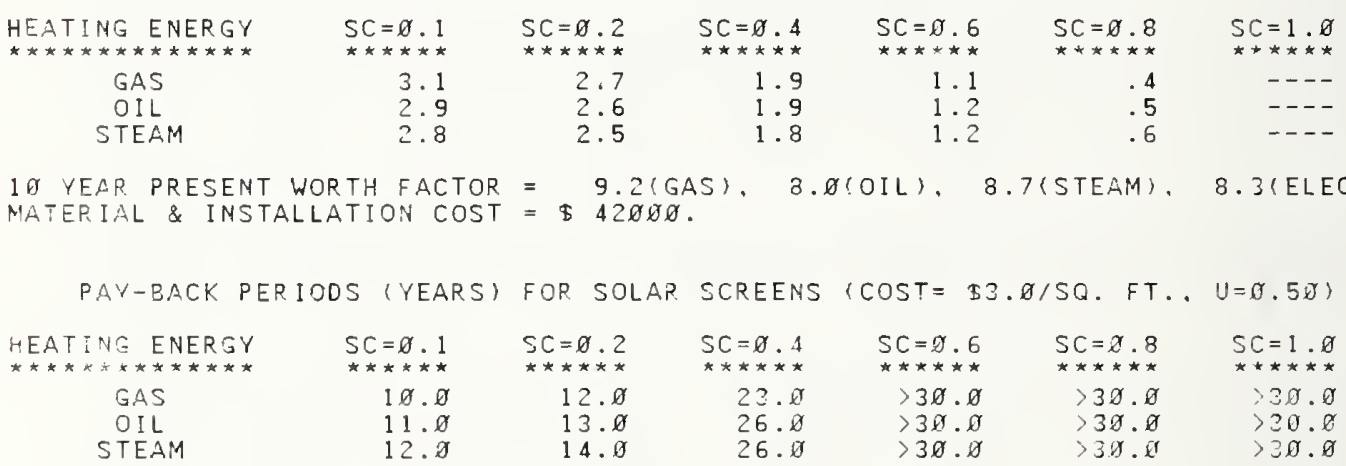

SAVINGS-TO-INVESTMENT RATIOS FOR SOLAR SCREENS (COST $=\$ 3 . \varnothing / 5 O . F T ., \quad \mathrm{J}=\varnothing .50)$

\begin{tabular}{|c|c|c|c|c|c|c|}
\hline $\begin{array}{l}\text { HEATI I I G ENERGY } \\
\text { EN* }\end{array}$ & $\begin{array}{l}\mathrm{SC}=\not \cdot 1 \\
\star \star \star \star \star \star \star * \star\end{array}$ & $\begin{array}{l}S C=\emptyset .2 \\
\star \star \star \star \star \star \star\end{array}$ & $\begin{array}{l}S C=\varnothing \cdot 4 \\
\star \star \star \star \star \star \star \star\end{array}$ & $\begin{array}{l}S C=\not D .6 \\
\star \star \star \star \star \star\end{array}$ & 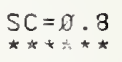 & $\begin{array}{l}S C=1 . \varnothing \\
\star \star \star \star \star \star\end{array}$ \\
\hline $\begin{array}{l}\text { GAS } \\
\text { OIL }\end{array}$ & $\begin{array}{l}1.5 \\
1.4\end{array}$ & $\begin{array}{l}1.3 \\
1.3\end{array}$ & $\begin{array}{r}.9 \\
.9 \\
9\end{array}$ & $\begin{array}{l}.6 \\
.6\end{array}$ & $\begin{array}{r}.2 \\
.3 \\
3\end{array}$ & $\begin{array}{l}---- \\
---- \\
----\end{array}$ \\
\hline
\end{tabular}

20 YEAR PRESENT WOP.TH FACTOR = 14.3 (GAS), $14.3(0 I L), 13.6$ (STEAM), 12,4 (ELEC) MATERIAL \& INSTALLATION COST $=\$ 126 \% 90$.

\begin{tabular}{|c|c|c|c|c|c|c|}
\hline PAY-BACK & (YEARS) & FOR SOLAR & SCREENS & $\angle \cos T=$ & SQ. F & $(1=\varnothing .5 \varnothing)$ \\
\hline EAT ING ENERGY & $\begin{array}{l}S C=\emptyset \cdot 1 \\
\star \star \star \star \star * *\end{array}$ & $\begin{array}{l}S C=\varnothing .2 \\
\star \star \star \star \star \star \star\end{array}$ & 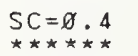 & $\begin{array}{l}\mathrm{SC}=\varnothing .6 \\
\star \star \star \star \star \star \star \star\end{array}$ & $\begin{array}{l}\mathrm{SC}=\varnothing .8 \\
\star \star * \star * *\end{array}$ & $\begin{array}{l}S C=1 . \varnothing \\
t * \star * * \star\end{array}$ \\
\hline $\begin{array}{l}\text { GAS } \\
\text { OIL } \\
\text { STEAM }\end{array}$ & $\begin{array}{l}>30.0 \\
>30.0 \\
>30.0\end{array}$ & $\begin{array}{l}>30.0 \\
>30.0 \\
>30.0\end{array}$ & $\begin{array}{l}>30.0 \\
>30.0 \\
>30.0\end{array}$ & $\begin{array}{l}>30.0 \\
>30.0 \\
>30.0\end{array}$ & $\begin{array}{l}>30.0 \\
>30.0 \\
330.0\end{array}$ & \\
\hline
\end{tabular}

SAVINGS-TO-INVESTMENT RATIOS FOR SOLAR SCREENS (COST $=\$ 6 . \varnothing / S Q . F T . \quad U=\varnothing .5 \varnothing)$

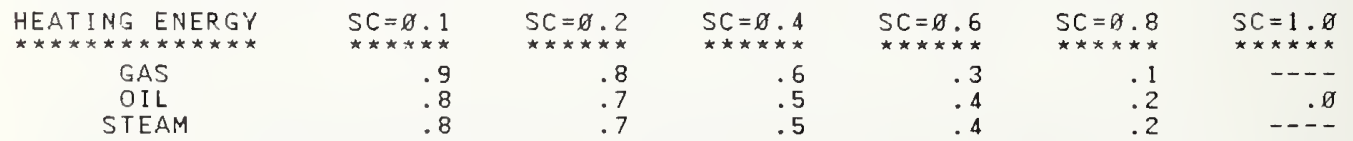
30 YEAR PRESENT WORTH FACTOR $=17.3$ (GAS). $21.3(01 \mathrm{~L}) .16 .2$ (STEAM). 14.5(ELEC) MATERIAL \& INSTALLATION COST $=\$ 252 \varnothing \varnothing \varnothing$. 
Table 12d. Cost-effectiveness for San Jose $U=0.84$, Al1-year Cooling FIRST YEAR ENERGY SAVINGS (DOLLARS) FOR SOLAR SCREENS $(U=\varnothing .84$ )

\begin{tabular}{|c|c|c|c|c|c|c|}
\hline 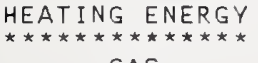 & 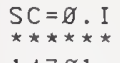 & SC $=\varnothing .2$ & $\begin{array}{l}\mathrm{SC}=\emptyset .4 \\
\star \star \star \star \star \star \star\end{array}$ & $\begin{array}{l}\mathrm{SC}=\text { Ø. } 6 \\
\star \star \star \star \star \star \star *\end{array}$ & $\begin{array}{l}\mathrm{SC}=9.8 \\
* \star * \star * *\end{array}$ & $\begin{array}{l}S C=I . D \\
\star \star \star \star \star \star \star *\end{array}$ \\
\hline $\begin{array}{l}\text { GAS } \\
\text { OIL } \\
\text { STEAM }\end{array}$ & $\begin{array}{l}14701 \\
12784 \\
11986\end{array}$ & $\begin{array}{l}13037 . \\
\text { II } 391 . \\
10705 .\end{array}$ & $\begin{array}{l}9426 . \\
8325 . \\
7867 .\end{array}$ & $\begin{array}{l}6053 . \\
5511 . \\
5286 .\end{array}$ & $\begin{array}{l}2732 . \\
2736 . \\
2738 .\end{array}$ & $\begin{array}{r}-714 . \\
-151 . \\
84 .\end{array}$ \\
\hline
\end{tabular}

ASSUMPTIONS: $\quad$ ELECTRICITY COST $=\$ .862 / \mathrm{KWH}$

HEATING FUEL COST $=\$ .023(\mathrm{GAS}), .038(O I L) . .045$ (STEAM)/YWH

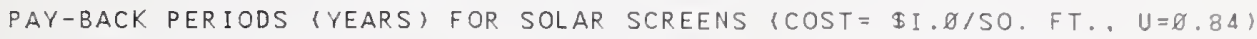

\begin{tabular}{|c|c|c|c|c|c|c|}
\hline 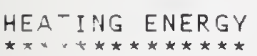 & 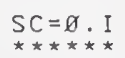 & $\begin{array}{l}\text { SC }=\emptyset .2 \\
\star \star \star \star \star \star \star *\end{array}$ & $\begin{array}{l}S C=\varnothing, 4 \\
\star \star \star \star \star \star \star *\end{array}$ & $\begin{array}{l}\mathrm{SC}=\varnothing .6 \\
\star \star \star \star * * *\end{array}$ & $\begin{array}{l}\mathrm{SC}=7.8 \\
\star \star \star \star \star \star \star *\end{array}$ & $\begin{array}{l}S C=I . \varnothing \\
\star \star \star \star \star \star \star\end{array}$ \\
\hline $\begin{array}{l}\text { GAS } \\
\text { OIL } \\
\text { STEAM }\end{array}$ & $\begin{array}{l}3.0 \\
4.0 \\
4 . \varnothing\end{array}$ & $\begin{array}{l}4 . \varnothing \\
4.0 \\
5 . \varnothing\end{array}$ & $\begin{array}{l}5.0 \\
6.0 \\
6.0\end{array}$ & $\begin{array}{r}9.0 \\
9.0 \\
\text { I0.0 }\end{array}$ & $\begin{array}{l}>3 \varnothing .0 \\
30.0 \\
30.0\end{array}$ & $\begin{array}{l}>30 . \not \\
, 30.0 \\
30.0\end{array}$ \\
\hline
\end{tabular}

SAVINGS-TO-INVESTMENT RATIOS FOR SOLAR SCREENS \{COST= $\$ 1.0 / S O . F T . . U=\emptyset .84$ )

\begin{tabular}{|c|c|c|c|c|c|c|}
\hline 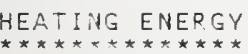 & $\begin{array}{l}S C=\emptyset \cdot I \\
\star \star \star \star \star \star \star\end{array}$ & $\begin{array}{l}\mathrm{SC}=\emptyset \cdot 2 \\
\star \star \star \star \star \star \star \star \star 2\end{array}$ & $\begin{array}{l}\mathrm{SC}=\varnothing \cdot .4 \\
\star \star \star \star \star \star \star\end{array}$ & $\begin{array}{l}\mathrm{SC}=\varnothing .6 \\
\star \star \star \star \star \star \star\end{array}$ & $\begin{array}{l}S C=\varnothing \cdot 8 \\
* * \star * * *\end{array}$ & $\begin{array}{l}S C=I \cdot \varnothing \\
* * * * * *\end{array}$ \\
\hline $\begin{aligned} & \text { GAS } \\
& \text { OIL } \\
& \text { STEAM }\end{aligned}$ & $\begin{array}{l}2.8 \\
2.5 \\
2.3\end{array}$ & $\begin{array}{l}2.5 \\
2.3 \\
2.0\end{array}$ & $\begin{array}{l}\text { I. } 8 \\
\text { I. } 6 \\
\text { I. } 5\end{array}$ & $\begin{array}{l}1.2 \\
\text { I. I } \\
1.0\end{array}$ & $\begin{array}{l}.5 \\
.5 \\
.5\end{array}$ & $\begin{array}{r}---\overline{-} \\
---\overline{0}\end{array}$ \\
\hline
\end{tabular}

1 У YEAF PRESENT WORTH FACTOR. = 9.2(GAS), 8. (OIL), 8.7(STEAM). 8.3(ELEC) MATERIAL \& INSTALLATION COST = $\$ 4200 \varnothing$.

PAY-BACK PERIODS (YEARS) FOR SOLAR SCREENS (COST $=\$ 3.0 / S O . F T ., U=6.34$ )

\begin{tabular}{|c|c|c|c|c|c|c|}
\hline $\begin{array}{l}\text { HEATING ENER.GY } \\
* * * * * * * * * * * * * * t\end{array}$ & $\begin{array}{l}\mathrm{SC}=\varnothing \cdot I \\
\star \star \star \star \star \star \star \star\end{array}$ & $\begin{array}{l}S C=0.2 \\
S_{* \star * * *}\end{array}$ & $\begin{array}{l}S C=\not .4 \\
\star * * * * *\end{array}$ & $\begin{array}{l}\mathrm{SC}=\pi \cdot 6 \\
* \star * * * *\end{array}$ & $\begin{array}{l}\mathrm{SC}=\not 2 \cdot 8 \\
\star \star \star * *\end{array}$ & $\begin{array}{l}S C=1 . \varnothing \\
* \star \star *\end{array}$ \\
\hline $\begin{array}{l}\text { GAS } \\
\text { OIL } \\
\text { STEAM }\end{array}$ & $\begin{array}{l}11.0 \\
11.0 \\
16.0\end{array}$ & $\begin{array}{l}\text { I } 4 . \varnothing \\
\text { I } 8 . \varnothing \\
2 \varnothing . \varnothing\end{array}$ & $\begin{aligned} & 27 . \varnothing \\
> & 30.0 \\
> & 30.0\end{aligned}$ & $\begin{array}{l}>30.0 \\
>3 \pi \cdot 9 \\
>3 \pi .8\end{array}$ & $\begin{array}{l}>3 x .0 \\
>30.0 \\
>39.0\end{array}$ & $\begin{array}{l}>30.0 \\
>30.0 \\
>30.0\end{array}$ \\
\hline
\end{tabular}

SAVINGS-TO-INVESTMENT R.ATIOS FOR SOLAR SCREENS (COST= $\$ 3.0 / 5 O . F T . \quad U=\pi .84$ )

\begin{tabular}{|c|c|c|c|c|c|c|}
\hline 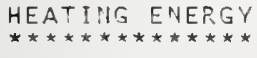 & $\begin{array}{l}\mathrm{SC}=\varnothing . \mathrm{I} \\
\star \star \star \star \star \star \star\end{array}$ & $\begin{array}{l}\mathrm{SC}=\varnothing \cdot 2 \\
\star \star \star \star \star \star \star \star\end{array}$ & $\begin{array}{l}\mathrm{SC}=\not \supset .4 \\
\star * \star \star \star \star *\end{array}$ & $\begin{array}{l}\mathrm{SC}=9.6 \\
\star \star \star \star * * *\end{array}$ & $\begin{array}{l}S C=\varnothing .8 \\
\star \star \star \star \star \star *\end{array}$ & $\begin{array}{l}S C=1 . \varnothing 0 \\
* * * * *\end{array}$ \\
\hline $\begin{array}{l}\text { GAS } \\
\text { OIL } \\
\text { STEAM }\end{array}$ & $\begin{array}{l}1.4 \\
1.2 \\
1.1\end{array}$ & $\begin{array}{l}1.2 \\
1.0 \\
1.0\end{array}$ & $\begin{array}{l}.9 \\
.8 \\
.7\end{array}$ & $\begin{array}{l}.6 \\
.5 \\
.5\end{array}$ & $\begin{array}{l}.3 \\
.3 \\
.3\end{array}$ & $\begin{array}{r}---\overline{0} \\
. \varnothing\end{array}$ \\
\hline
\end{tabular}

20 /EAR PRESENT WORTH FACTOP = 14.3(GAS), $14.8(O I L) .13 .6(S T E A M) .12 .4$ (ELEC) MATERIAL \& INSTALLATION COST = \$126Ø囚Ø.

PAY-BACK PERIODS (YEARS) FOR SOLAR SCREENS (COST $=\$ 6 . \varnothing / S O . F T \ldots U=\varnothing .84$ )

\begin{tabular}{|c|c|c|c|c|c|c|}
\hline $\begin{array}{l}\text { HEAT I IIS ENERGY } \\
\star \star \star * * * * \star * \star * \star * \star *\end{array}$ & $\begin{array}{l}\mathrm{SC}=\mathbb{D} \cdot \mathrm{I} \\
\star \star \star \star \star \star\end{array}$ & $\begin{array}{l}\mathrm{SC}=\theta \cdot 2 \\
\star * * * * *\end{array}$ & $\begin{array}{l}\text { SC }=\varnothing .4 \\
\star \star \star \star \star \star *\end{array}$ & $\begin{array}{l}\mathrm{SC}=0.6 \\
* * * * * *\end{array}$ & $\begin{array}{l}\mathrm{SC}=\mathfrak{g} .8 \\
\star \star \star \star \star \star\end{array}$ & $\begin{array}{l}S C=1 . J \\
* * * * * *\end{array}$ \\
\hline $\begin{array}{l}\text { GAS } \\
\text { DIL } \\
\text { STEAM. }\end{array}$ & $\begin{array}{l}>3 \theta \cdot \theta \\
>3 \theta \cdot \theta \\
>36.0\end{array}$ & $\begin{array}{l}>3 \theta . \theta \\
>3 \varnothing . \theta \\
>3 \sigma . \varnothing\end{array}$ & $\begin{array}{l}>30.0 \\
>30.0 \\
>30.8\end{array}$ & $\begin{array}{l}>3 \theta \cdot \theta \\
>30.0 \\
>30.0\end{array}$ & $\begin{array}{l}>30.0 \\
>30.0 \\
>30.0\end{array}$ & $\begin{array}{l}>3 \theta \cdot \theta \\
>30.0 \\
>30 . \theta\end{array}$ \\
\hline
\end{tabular}

SAVINGS-TO-INVESTMENT RATIOS FOR SOLAR SCREENS (COST= $56.0 / 5 O . F T ., U=9.8 \downarrow$ )

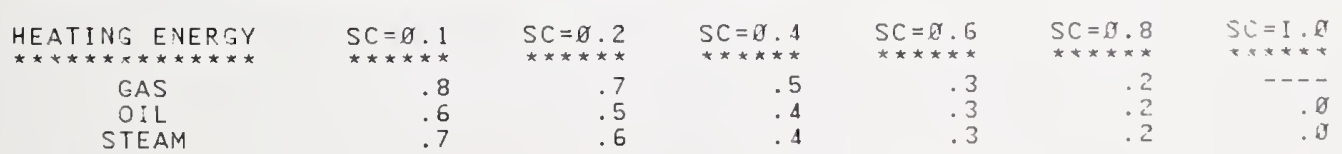

30 VEAR PRESENT WORTH FACTOR = 17.3 (GAS), $21.3(0 I L), 16.2$ (STEAM), $14.5(E L E C)$ MATERIAL \& INSTALLATION COST = \$252000. 

NBS-114A (REV. 2-8C)

\begin{tabular}{|c|c|c|c|}
\hline $\begin{array}{c}\text { U.S. DEPT. OF COMM. } \\
\text { BIBLIOGRAPHIC DATA } \\
\text { SHEET (See instructions) }\end{array}$ & $\begin{array}{c}\text { 1. PUBLICATION OR } \\
\text { REPORT NO. }\end{array}$ & 2. Performing Organ. Report No. 3. Publication Date \\
\hline NBS BSS 161 & May 1984 \\
\hline
\end{tabular}

4. TITLE AND SUBTITLE

Effectiveness of Solar Shading for an Office Building

5. AUTHOR(S)

S. Treado, J. Barnett, W. Remmert

6. PERFORMING ORGANIZATION (If joint or other than NBS, see instructions)

NATIONAL BUREAU OF STANDARDS

DEPARTMENT OF COMMERCE

WASHINGTON, D.C. 20234

7. ContractGrant No.

8. Type of Report \& Period Covered

Final

9. SPONSORING ORGANIZATION NAME AND COMPLETE ADDRESS (Street. City. State, ZIP)

Design and Construction Division, General Services Administration, Washington, DC 20407; Naval Facilities Engineering Command, U.S. Navy, Washington, DC 20350; Directorate of Civil Engineering, U.S. Air Force, Washington, DC 20330; and Office of Chief of Engineers, U.S. Army, Washington, DC 20310.

10. SUPPLEMENTARY NOTES

Library of Congress Catalog Card Number: 84-601038

$\square$ Document describes a computer program; SF-185, FIPS Software Summary, is attached.

11. ABSTRACT (A 200-word or less factual summary of most significant information. If document includes a significant bibliography or literature survey. mention it here)

The impact of solar shading of windows on building energy consumption, energy costs and occupant comfort is examined for a typical office building. Measurements of the solar and thermal performance characteristics of three solar screens are reported. Using the DOE-2 computer program, annual building energy simulations were performed for seven climatic locations in the United States. Thirteen combinations of window thermal transmittance and shading coefficient are examined for each location. The analysis includes separate evaluations for buildings with all-year cooling and summer-only cooling. The percentage of occupied hours when overheating occurs in perimeter office areas is presented. A life-cycle cost analysis is used to determine payback periods and savings-toinvestment ratios for three combinations of shading device first cost and expected life. The evaluation assumes that any shading devices are fixed, and that daylighting is not used to offset interior lighting requirements.

The results indicate that solar shading can reduce building energy consumption and improve comfort conditions in buildings with significant cooling loads. The optinum shading device characteristics vary with clinatic location. Solar shading is more beneficial to buildings which are cooled all year, than buildings with summer-only cooling.

12. KEY WORDS (Six to twelve entries; alphabetical order; capitalize only proper names; and separate key words by semicolons) building energy analysis; cooling loads; heating loads; solar screens; solar shading; window management; windows.

13. AVAILABILITY

$X$ Unlimited

$\square$ For Official Distribution. Do Not Release to NTIS

[X] Order From Superintendent of Documents, U.S. Government Printing Office, Washington, D.C. 20402.

14. NO. OF PRINTED PAGES

L_ Order From National Technical Information Service (NTIS), Springfield, VA. 22161

111

15. Price 



\section{NBS TECHNICAL PUBLICATIONS}

\section{PERIODICALS}

JOURNAL OF RESEARCH-The Journal of Research of the National Bureau of Standards reports NBS research and development in those disciplines of the physical and engineering sciences in which the Bureau is active. These include physics, chemistry, engineering, mathematics, and computer sciences. Papers cover a broad range of subjects, with major emphasis on measurement methodology and the basic technology underlying standardization. Also included from time to time are survey articles on topics closely related to the Bureau's technical and scientific programs. As a special service to subscribers each issue contains complete citations to all recent Bureau publications in both NBS and nonNBS media. Issued six times a year. Annual subscription: domestic $\$ 18$; foreign $\$ 22.50$. Single copy, $\$ 5.50$ domestic; $\$ 6.90$ foreign.

\section{NONPERIODICALS}

Monographs-Major contributions to the technical literature on various subjects related to the Bureau's scientific and technical activities.

Handbooks-Recommended codes of engineering and industrial practice (including safety codes) developed in cosperation with interested industries, professional organizations, and regulatory bodies.

Special Publications-Include proceedings of conferences sponsored by NBS, NBS annual reports, and other special publications appropriate to this grouping such as wall charts, pocket cards, and bibliographies.

Applied Mathematics Series-Mathematical tables, manuals, and studies of special interest to physicists, engineers, chemists, biologists, mathematicians, computer programmers, and others engaged in scientific and technical work

National Standard Reference Data Series-Provides quantitative data on the physical and chemical properties of materials, compiled from the world's literature and critically evaluated. Developed under a worldwide program coordinated by NBS under the authority of the National Standard Data Act (Public Law 90-396).

NOTE: The principal publication outlet for the foregoing data is the Journal of Physical and Chemical Reference Data (JPCRD) published quarterly for NBS by the American Chemical Society (ACS) and the American Institute of Physics (AIP). Subscriptions, reprints, and supplements available from ACS, 1155 Sixteenth St. NW, Washington, DC 20056.
Building Science Series-Disseminates technical I- Tormation developed at the Bureau on building materials, components, systems, and whole structures. The series presents research results, test methods, and performance criteria related to the structural and environmental functions and the durability and safety characteristics of building elements and systems.

Technical Notes-Studies or reports which are complete in them. selves but restrictive in their treatment of a subject. Analogous to monographs but not so comprehensive in scope or definitive in treatment of the subject area. Often serve as a vehicle for final reports of work performed at NBS under the sponsorship of other government agencies.

Voluntary Product Standards-Developed under procedures published by the Department of Commerce in Part 10, Title 15, of the Code of Federal Regulations. The standards establish nationally recognized requirements for products, and provide all concerned interests with a basis for common understanding of the characteristics of the products. NBS administers this program as a supplement to the activities of the private sector standardizing organizations.

Consumer Information Series-Practical information, based on NBS research and experience, covering areas of interest to the consumer. Easily understandable language and illustrations provide useful background knowledge for shopping in today's technological marketplace.

Order the above NBS publications from: Superintendent of Documents. Government Printing Office, Washington, DC 20402.

Order the following NBS publications-FIPS and NBSIR's-from the National Technical Information Service, Springfield. VA 22161.

Federal Information Processing Standards Publications (FIPS PUB)-Publications in this series collectively constitute the Federal Information Processing Standards Register. The Register serves as the official source of information in the Federal Government regarding standards issued by NBS pursuant to the Federal Property and Administrative Services Act of 1949 as amended, Public Law 89-306 (79 Stat. 1/27), and as implemented by Executive Order 11717 (38 FR 12315, dated May 11. 1973) and Part 6 of Title 15 CFR (Code of Federal Regulations).

NBS Interagency Reports (NBSIR)-A special series of interim or final reports on work performed by NBS for outside sponsors (both government and non-government). In general, initial distribution is handled by the sponsor: public distribution is by the National Technical Information Service, Springfield, VA 22161, in paper copy or microfiche form. 
U.S. Department of Commerce

National Bureau of Standards

Washington, D.C. 20234

Official Business

Penaity for Private Use $\$ 300$ 